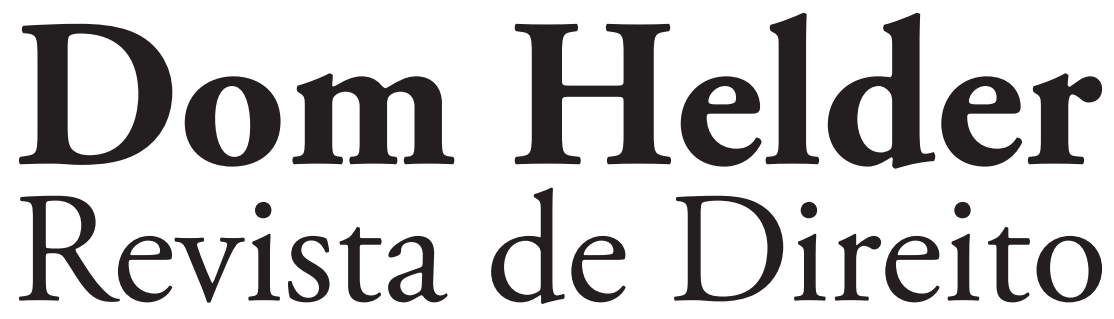




\section{ESCOLA SUPERIOR DOM HELDER CÂMARA}

Reitor: Paulo Umberto Stumpf, SJ.

Vice-Reitor: Estevâo D'Ávila de Freitas

\section{EDITORA DOM HELDER}

Coordenador de Editoria: José Adércio Leite Sampaio

Diretora Executiva: Beatriz Souza Costa

Endereço: R. Álvares Maciel, 628, B. Santa Efigênia, CEP: 30150-250 - Belo Horizonte-MG.

Tel.: (31) 2125-8836. E-mail: revistadomhelder@domhelder.edu.br

\section{Editora Chefe:}

Beatriz Souza Costa

\section{Editores Adjuntos:}

Anacélia Santos Rocha

Franclim Jorge Sobral de Brito

Secretários de Edição:

Cristialan Belça da Silva

Rafael Faber Fernandes

Revisão de originais: Casa de Ideias

Editoraçáo, arte-final e capa:

Rômulo Garcias

Periodicidade: quadrimestral

Versáo Eletrônica:

http://www.domhelder.edu.br/revista/index.php/dhrevistadedireito

Ficha catalográfica

D666 Dom Helder Revista de Direito

v. 1, 2019. Belo Horizonte: Escola Superior Dom

Helder Câmara, 2019.

v. 2, n. 3, Maio/Ago. 2019. (Ed. Dom Helder)

ISSN 2596-0601 (Eletrônico)

1.Direito - periódicos, 2. Escola Superior Dom Helder Câmara

I. Título.

CDU 34 (05)

CDD 340.05

Bibliotecário responsável: Anderson Roberto de Rezende CRB6 - 3094 


\section{Revista dos Cursos de Graduação e Pós-Graduaçáo \\ (Lato Sensu e Stricto Sensu) da Escola Superior Dom Helder Câmara}

\section{EXPEDIENTE}

Editora Chefe: Beatriz Souza Costa

\section{Conselho Editorial}

Profa. Dra. Ana Elisa Liberatore Silva Bechara - Universidade de São Paulo (São Paulo, SP), Brasil. Prof. Dr. Délton Winter de Carvalho - Universidade do Vale do Rio dos Sinos (São Leopoldo, RS), Brasil. Prof. Dr. Felipe Chiarello de Souza Pinto - Universidade Presbiteriana Mackenzie (São Paulo, SP), Brasil. Profa. Dra. Helena Regina Lobo da Costa - Universidade de São Paulo (São Paulo, SP), Brasil. Profa. Dra. Liziane Paixão Oliveira - Universidade Tiradentes (Aracaju, SE), Brasil. Profa. Dra. Mariana Ribeiro Santiago - Universidade de Marília (Marília, SP), Brasil. Profa. Dra. Raquel Cavalcanti Ramos Machado - Universidade Federal do Ceará (Fortaleza, CE), Brasil. Prof. Dr. Valmir Cesar Pozzetti - Universidade do Estado do Amazonas (Manaus, AM) e Universidade Federal do Amazonas (Manaus, AM), Brasil. Prof

\section{Conselho Avaliador}

André Sopas de Melo Bandeira - Ministério dos Negócios Estrangeiros de Portugal, MNE - Lisboa, Portugal. André Augusto Giuriatto Ferraço - Universidade de Brasília (UnB) - Brasília-DF, Brasil. Bruna Schlindwein Zeni - Universidade de Mogi das Cruzes (UMC) - São Paulo-SP, Brasil. Camila Barreto Pinto Silva - Universidade Metropolitana de Santos (UNIMES) - Santos-SP, Brasil. Eduardo Baldissera Carvalho Salles - Pontifícia Universidade Católica do Rio Grande do Sul (PUC-RS) Porto Alegre-RS, Brasil. Elisaide Trevisam - Universidade Federal de Mato Grosso do Sul (UFMS) Pioneiros-MS, Brasil. Eloi Martins Senhoras - Universidade Federal de Roraima (UFRR) - Boa VistaRR, Brasil. Fernando Barotti dos Santos - Escola Superior Dom Helder Câmara (ESDHC) - Belo Horizonte-MG, Brasil. Fulvia Helena de Gioia - Universidade Presbiteriana Mackenzie (UPM) - São Paulo-SP, Brasil. Guilherme Saldanha Santana - Universidade Autónoma de Lisboa (AUTÓNOMA) - Lisboa, Portugal. Leila Maria da Juda Bijos - Universidade de Brasília (UnB) - Brasília-DF, Brasil. Marlene Helena Oliveira França - Universidade Federal da Paraíba (UFPB) - João Pessoa-PB, Brasil. Mateus de Oliveira Fornasier - Universidade Regional do Noroeste do Estado do Rio Grande do Sul (UNIJUÍ) - Ijuí-RS, Brasil. Miriam Olivia Knopik Ferraz - Pontifícia Universidade Católica do Paraná (PUC-PR) - Curitiba-PR, Brasil. Murillo Ricart Mendes Souza Silva - Centro Universitário FG (UNIFG) - Guanambi-BA, Brasil. Renato Braz Mehanna Khamis - Universidade Santa Cecília (UNISANTA) - Santos-SP, Brasil. Rocco Antonio Rangel Rosso Nelson - Instituto Federal do Rio Grande do Norte (IFRN) - Mossoró-RN, Brasil. Silvia Helena Antunes Santos - Universidade Luterana do Brasil (ULBRA) - Manaus-AM, Brasil. Tainá Fernanda Pedrini - Universidade do Vale do Itajaí (UNIVALI) - Itajaí-SC, Brasil. 


\section{Sumário}

6 APRESENTAÇÃO

9 A PARTILHA SUCESSÓRIA NA UNIÃO ESTÁVEL, SUSTENTABILIDADE E A DIGNIDADE DA PESSOA HUMANA

Magno Federici Gomes

Marina de Sá Souza Oliveira

Patrícia Batista

41 A AUTORREGULAÇÃO DOS RISCOS DAS NOVAS TECNOLOGIAS NO ÂMBITO INTERNACIONAL: UM ESTUDO A PARTIR DA ISO/TC 229

Reginaldo Pereira

Jaqueline Kelli Percio

Diego Sacomori

59 A MEDIAÇÃO COMO MEIO EMANCIPADOR DO CONFLITO E RESGATE DA CIDADANIA Janete Rosa Martins

81 ANÁLISE JURISPRUDENCIAL: A TRIBUTAÇÃO DO DIREITO DE IMAGEM DO ATLETA PROFISSIONAL DE FUTEBOL

Leandro Miotto Mendes

103 EX-TARIFÁRIO: POSSIBILIDADE DE EXTENSÃO DOS EFEITOS DA RESOLUÇÃO PUBLICADA PELO PODER EXECUTIVO QUE O INSTITUI Paulo Alfredo Benfica Marra

129 ANÁLISE DA ARGUIÇÃO DE DESCUMPRIMENTO DE PRECEITO FUNDAMENTAL - ADPF - 186 À LUZ DA HERMENÊUTICA

FENOMENOLÓGICA E DO ATIVISMO JUDICIAL

Luana Paixão Dantas do Rosário

Fernando Leal Menezes

165 ANIMAIS NÃO HUMANOS: DIREITO À VIDA E À DIGNIDADE Valmir Cesar Pozzetti

Elizabeth Beatriz Rodrigues Braga

191 O PODER DE POLÍCIA DO CBMMG E O PARECER N. 15.719/2016 DA AGE: UMA ANÁLISE À LUZ DOS PRINCÍPIOS DA PREVENÇÃO E EFICIÊNCIA

Pedro Henrique Moreira da Silva

Pedro Henrique Cordeiro Gonçalves

211 A LEGALIDADE DAS ASSOCIAÇÓES DE PROTEÇÃO VEICULAR COMO ÓBICE AO REGIME FISCALIZATÓRIO PREVISTO NO

DECRETO-LEI N. 73 DE 1966

Thiago Loures Machado Moura Monteiro

Henrique de Almeida Santos 


\section{APRESENTAÇÁO}

Como já era de se esperar, a Dom Helder Revista de Direito supera todas as expectativas com relação aos artigos publicados. Neste número, foram contemplados artigos sobre temas variados, como sucessôes, governança socioambiental, mediação, futebol, benefícios tributários, arguição de descumprimento de preceito fundamental (ADPF), animais não humanos, Poder de Polícia e Associações de Proteção Veicular. A possibilidade para obtenção dessa riqueza científica é proveniente de autores de alta competência em investigação e da linha de pesquisa da revista, que tem como escopo: Justiça, Estado e Cidadania nas Sociedades Contemporâneas.

O primeiro artigo deste número, intitulado "A partilha sucessória na união estável, sustentabilidade e a dignidade da pessoa humana" foi desenvolvido pelos autores Magno Federici Gomes, Pós-Doutor em Direito Público pela Universidade de Lisboa, Marina de Sá Souza e Patrícia Batista, ambas graduadas pela Dom Helder Escola de Direito. Os autores analisam, de maneira brilhante, a decisão do Supremo Tribunal Federal (STF) que declarou inconstitucional o art. 1.790 do Código Civil, que diferenciava a sucessão pós-morte para o companheiro supérstite. É uma pesquisa importante porque averigua quais foram as bases da decisão e as consequências sociais e econômicas ocorridas no tempo.

Da Unochapecó, o Professor Doutor Reginaldo Pereira, em conjunto com Jaqueline K. Percio, mestranda também pela Unochapecó, e com o engenheiro Diego Samacori, abordam a questão das novas tecnologias. O artigo "A autorregulação dos riscos das novas tecnologias no âmbito internacional: um estudo a partir da ISO/TC 229" discute os desafios que a nanotecnologia impóe à governança de riscos socioambientais e, também, aborda a autorregulação como elemento transnormativo de regulação das novas tecnologias.

Por sua vez, a Doutora Janete Rosa Martins, professora da Unisinos, em "A mediação como meio emancipador do conflito e resgate da cidadania", traz a lume a mediação como meio emancipatório do conflito, e também o resgate da cidadania com atores envolvidos em controvérsias, as quais ocorrem em virtude da falta de diálogo, autonomia e sensibilidade, que são problemas recorrentes de nossa sociedade, em razão da falta de alteridade, ou seja, preocupação real com a vida do outro.

Seguindo essa ordem, Leandro Miotto Mendes, proveniente do Centro Universitário de Rio Preto, desenvolve texto muito relevante, intitulado "Análise 
jurisprudencial: a tributação do direito de imagem do atleta profissional de futebol". Trata-se de um assunto pouquíssimo abordado e de muita importância para muitos atletas que celebram contratos com clubes de futebol, algumas vezes, de valores altíssimos. $\mathrm{O}$ autor analisa, também, as empresas que administram o direito de imagem e a validade da cessão dos direitos dos atletas para essas empresas.

Também na temática tributária, Paulo Alfredo B. Marra, pós-graduado pela Fumec/BH, apresenta, em "Ex-Tarifário: possibilidade de extensão dos efeitos da resolução publicada pelo Poder Executivo que o institui”, uma reflexão sobre benefícios tributários concedidos na importação, entre os quais se inclui o Ex-Tarifário, porque algumas vezes têm sua fruiçáo prejudicada pela morosidade que afeta o Poder Executivo no ato de formalização do benefício.

Com o artigo intitulado "Análise da Arguição de Descumprimento de Preceito Fundamental - ADPF-186 - à Luz da Hermenêutica Fenomenológica e do Ativismo Judicial", os autores Doutora Luana P. D. Rosário, professora da UESC/BA, e o bacharel Fernando Leal Menezes analisam a ADPF n. 186 com o objetivo de traçar o perfil epistemológico, isso porque a pesquisa parte da hipótese de que, à luz da hermenêutica fenomenológica, a decisão sofreu ativismo judicial.

De outro giro, o Doutor Valmir Pozzeti, professor na UEA e UFAM, e a Bacharel em Direito Elizabeth Beatriz R. Braga observam, no texto "Animais não humanos: direito à vida e à dignidade", a utilização de animais não humanos no cotidiano e como o Poder Público pode garantir, efetivamente, a proteção desses animais.

Em "O poder de polícia do CBMMG e o Parecer n. 15.719/2016 da AGE: uma análise à luz dos princípios da prevenção e eficiência”, Pedro Henrique M. da Silva, Mestre em Direito, e Pedro H. Cordeiro Gonçalves, bacharelando em Engenharia pelo CEFET/MG, apresentam a atuação do Corpo de Bombeiros Militar de Minas Gerais na prevenção de incêndios e pânico. Este é um tema de prioridade máxima quando se observam algumas tragédias em casas noturnas. Logo, o texto preocupa-se em demonstrar a limitação do poder de polícia com relação à possibilidade de interdição de estabelecimentos que não estejam regulares perante as normas técnicas necessárias para seu funcionamento.

$\mathrm{O}$ artigo intitulado "A Legalidade das Associaçôes de Proteção Veicular como Óbice ao Regime Fiscalizatório Previsto no Decreto-Lei n. 73 de 1966", desenvolvido pelos autores Thiago Loures M. Moura Monteiro, Mestre pela Dom Helder, e Henrique de Almeida Santos, graduando pela Dom Helder, analisa a legalidade das Associaçóes de Proteção Veiculares e a incompetência da Susep para 
fiscalização, tendo em vista as diferenças existentes entre contrato de seguro e proteção automotiva e, ainda, a necessidade de criaçáo de uma autarquia para fiscalização das associações, tendo por base a legislação brasileira e decisão do STJ. Assim, com a descrição de todos esses artigos esmerados por seus autores na pesquisa, a Dom Helder Revista de Direito deseja à comunidade científica uma excelente leitura.

\section{Beatriz Souza Costa}

Editora da Dom Helder Revista de Direito Professora da Graduação e do Programa de Pós-Graduação em Direito Ambiental e Desenvolvimento Sustentável da Dom Helder Escola de Direito 


\title{
A PARTILHA SUCESSÓRIA NA UNIÁO ESTÁVEL, SUSTENTABILIDADE E A DIGNIDADE DA PESSOA HUMANA ${ }^{1}$
}

\author{
Magno Federici Gomes ${ }^{2}$ \\ Escola Superior Dom Helder Câmara (ESDHC) \\ Pontifícia Universidade Católica de Minas Gerais (PUC-MINAS) \\ Faculdade de Direito Arnaldo Janssen (Faculdade Arnaldo) \\ Marina de Sá Souza Oliveira ${ }^{3}$ \\ Escola Superior Dom Helder Câmara (ESDHC) \\ Escola Superior Dom Helder Câmara (ESDHC) \\ Artigo recebido em: 09/05/2019. \\ Artigo aceito em: 27/08/2019.
}

\section{Resumo}

O presente artigo busca analisar a também, a análise detida da decisão decisão do Supremo Tribunal Federal referida, com vistas a entender (STF) que declarou inconstitucional quais foram os elementos que a o art. 1.790 do Código Civil (CC), fundamentaram. O trabalho pautaque diferenciava a sucessão pós-morte -se no método teórico documental para o companheiro supérstite na do tipo dedutivo, com exploração união estável. Buscar-se-á compreender os fundamentos da referida decisão doutrinária, jurisprudencial e legal, vez se apoia na doutrina jurídica nacional, mediante uma análise histórico-social, bem como entender as repercussóes na legislação e nos votos proferidos pelos ministros na referida decisão. sociais dela decorrentes. Objetiva-se, Entendeu-se que a decisão do STF

1 Trabalho financiado pelo Projeto FAPEMIG 22869, resultante dos Grupos de Pesquisas (CNPQ): Regulação Ambiental da Atividade Econômica Sustentável (REGA), Núcleo de Estudos sobre Gestão de Políticas Públicas (NEGESP), Metamorfose Jurídica e Centro de Investigação \& Desenvolvimento sobre Direito e Sociedade (CEDIS)/FCT-PT.

2 Estágio Pós-doutoral em Direito Público e Educação pela Universidade Nova de Lisboa-Portugal (UNL) (Bolsa CAPES/BEX 3642/07-0). Estágios Pós-doutorais em Direito Civil e Processual Civil, Doutorado em Direito e Mestrado em Direito Processual pela Universidad de Deusto-Espanha (Bolsa da Cátedra UNESCO e do Gobierno Vasco-Espanha). Mestre em Educação pela PUC-MINAS. Professor do Doutorado e Mestrado Acadêmico em Direito Ambiental e Desenvolvimento Sustentável na ESDHC. Professor adjunto da PUC-MINAS e professor titular licenciado da Faculdade Arnaldo. Advogado sócio do escritório Moraes \& Federici Advocacia Associada. Líder do Grupo de Pesquisa: Regulação Ambiental da Atividade Econômica Sustentável (REGA)/ CNPQ-BRA e integrante dos grupos: CEDIS/FCT-PT, NEGESP/CNPQ-BRA e Metamorfose Jurídica/CNPQ-BRA. ORCID: <http://orcid.org/0000-0002-4711-5310> / E-mail: federici@pucminas.br

3 Graduada em Direito, na modalidade Integral, pela ESDHC. Advogada militante. E-mail: marinasasouz@ hotmail.com

4 Graduada em Direito, na modalidade Integral, pela ESDHC. Advogada militante. E-mail: pattypatricia.13@ gmail.com 
refletiu os valores sociais brasileiros e equalizou o tratamento de sujeitos em situaçóes semelhantes, refletindo o que se pretende nas previsóes constitucionais, como uma forma de se verem respeitados os princípios constitucionais que permeiam todo o ordenamento jurídico, notadamente os princípios da igualdade, da vedação ao retrocesso, da sustentabilidade e da dignidade da pessoa humana.

Palavras-chave: inconstitucionalidade; regime de bens; sucessóes; sustentabilidade pela dignidade da pessoa humana; união estável.

\section{HERITAGE SHARING IN THE STABLE COMPANIONSHIP, SUSTAINABILITY AND THE DIGNITY OF THE HUMAN PERSON}

\section{Abstract}

This paper seeks to analyze the decision of the Brazilian Supreme Federal Court (STF) that declared unconstitutional the article 1790 of the Civil Code (CC), which differentiated the postmortem succession for the companion in the stable union. It will seek to understand the grounds of this decision through a historical-social analysis, as well as understand the social repercussions of $i$. The objective is also to analyze the decision, with a view to understanding what were the elements that substantiated the decision. The paper is based on the theoretical documentary method of deductive type, with doctrinal, jurisprudential and legal exploration, instead relies on national legal doctrine, legislation and votes cast by the Ministers in that decision. It was understood that the decision of the Supreme Court reflected Brazilian social values and equalized the treatment of subjects in similar situations, reflecting what is intended in the constitutional provisions, as a way to be respected the constitutional principles that permeate the entire legal system, notably the principles of equality, probibition of regression, sustainability and the dignity of the human person.

Keywords: property regime; sharing; stable companionship; sustainability through human dignity; unconstitutionality. 


\section{Introdução}

O presente artigo trata da decisão do Supremo Tribunal Federal (STF) que, em 2016, alterou as regras da partilha de bens na união estável. Na decisão proferida, entendeu-se não ser mais possível distinguir, na partilha, a situação de companheiro e cônjuge, por ser o tratamento diferenciado inconstitucional.

A decisão foi proferida em sede de caso que foi declarado de repercussão geral em abril de 2015. Assim transcorreu o processo até sua recepção pelo STF: em primeira instância, entendeu o magistrado que a companheira, não obstante a regra do regime de comunhão parcial de bens, faria jus à partilha conforme a comunhão total de bens. Após recurso, o Tribunal de Justiça de Minas Gerais (TJMG) entendeu que a decisão não merecia vigorar, conforme o entendimento legal, doutrinário e jurisprudencial, e, assim, a viúva faria jus a somente $1 / 3$ dos bens de seu falecido companheiro, permanecendo o restante dos bens com os três irmãos do falecido.

Tal disposição de partilha está prevista no art. 1.790 do Código Civil de 2002 (CC/2002) e foi considerada inconstitucional pelo voto da maioria dos ministros do STF.

Este trabalho busca compreender, com uma análise histórica e jurídica, os fundamentos da decisão do STF e, assim, analisar se a decisão prolatada apresenta lastro com as mudanças sociais e a renovaçâo dos valores jurídicos aplicados à sucessão por morte.

O debate é centrado, durante todo o artigo, nas consequências e fundamentaçóes que motivaram o STF a determinar a inconstitucionalidade de um artigo vigente desde 2002 e quais mudanças legislativas e sociais orientaram a decisão da referida corte.

$\mathrm{O}$ problema que se pretende solucionar passa pelo seguinte questionamento: qual a fundamentação do STF para declarar inconstitucional o art. 1.790 do CC/2002 e quais serão as repercussôes de tal decisão?

Tal questionamento encontra relevância tanto sociológica quanto jurídica, ao entender que fazem jus os companheiros à sucessão dos casados, o STF dá reconhecimento equalizado entre ambas as formas de constituição de família em matéria de partilha de bens no pós-morte, e essa mudança representa um direito conquistado por todos os cidadãos que constituíram sua família pela união estável, constitucionalmente reconhecida.

Como hipótese, prevê-se que a declaração de inconstitucionalidade do referido artigo se deu em consonância com os princípios que regem o ordenamento jurídico brasileiro, baseando-se a decisão na igualdade, na sustentabilidade e 
na dignidade da pessoa humana, com vistas a equiparar e igualar o tratamento jurídico da uniáo estável ao do casamento.

A metodologia utilizada na pesquisa pautou-se no método teórico documental do tipo dedutivo com análise e exploração doutrinária, legal e predominantemente jurisprudencial, eis que o objetivo da pesquisa foi destrinchar a decisão de declaração de inconstitucionalidade do art. 1.790 do CC/2002. Utilizaram-se como fundamentos teóricos para a elaboração deste trabalho as obras de Hironaka (2007) e Gonçalves (2019).

O trabalho inicia-se com uma análise histórica da união estável no direito brasileiro e suas fontes e inspiraçóes, bem como avanços e retrocessos, para, com essas noçóes propedêuticas, adentrar preceitos referentes à dignidade da pessoa humana e à sustentabilidade que perpassam o caso e, assim, analisar de fato a decisão do STF. No segundo tópico, buscou-se verificar o conceito de sustentabilidade, bem como se esta se aplica ao assunto em questáo, sendo ou náo compatível com a dignidade da pessoa humana. Em seguida, analisou-se o Recurso Extraordinário (RE) n. 878.694 com o detalhamento dos argumentos da decisão do referido recurso. Por fim, analisaram-se a dinâmica do julgamento e seu desenvolvimento.

\section{Evolução histórica da união estável no Direito Brasileiro}

A colonização portuguesa no Brasil trouxe consigo os valores da Igreja Católica. Tão marcante é a presença da religiāo no ordenamento brasileiro que a primeira Constituição, promulgada ainda na fase imperial, em 1824, consagrou a religiáo católica apostólica como oficial. Marca, assim, a direta influência do Direito canônico na formação da legislaçáo brasileira. Como consequência, só se admitia como casamento aquele realizado com todas as formalidades determinadas por essa religião.

Após a proclamação da República, em 1889, o casamento civil passou a ser considerado válido no ordenamento jurídico brasileiro. O Decreto n. 181/1890 passou a regular os trâmites do casamento civil e a determinação legal foi, então, recepcionada pela Constituição Federal de 1891 (CF/1891).

Passados alguns anos, com o surgimento do Código Civil de 1916 (CC/1916), não se notaram mudanças fundamentais na instituiçẫo do casamento, pois o referido dispositivo legal continuou considerando o casamento civil a única forma de constituição de família, como reflexo da predominante cultura de família patriarcal. 
Além de náo propor qualquer tipo de proteção a nenhuma outra forma de família, o CC/1916 trouxe consigo uma maior repressão a qualquer tipo de união que não fosse o casamento civil. A legislação buscava afastar a incidência de uniôes "atípicas", à época, denominadas "concubinato", em que havia a união de homem e mulher com o intuito de constituir família, não obstante a ausência de casamento civil. Mais além, reforçava o regime do casamento civil, como se nota no art. 248, inc. IV, do CC/1916, que dava direito à mulher casada de demandar em juízo os bens adquiridos por esforço comum que porventura fossem transferidos à concubina pelo de cujus antes de vir a falecer, e do art. 1.177, o qual previa que toda doação feita pelo cônjuge em adultério ao seu amante poderia ser posteriormente anulada tanto pelo cônjuge supérstite quanto pelos herdeiros necessários. Assim, prelecionam, respectivamente, os artigos mencionados:

Art. 248. A mulher casada pode livremente:

[...] IV - reivindicar os bens comuns, móveis ou imóveis, doados ou transferidos pelo marido à concubina; Parágrafo único. Este direito prevalece, esteja ou não a mulher em companhia do marido, e ainda que a doação se dissimule em venda ou outro contrato. [...].

Art. 1.177. A doação do cônjuge adúltero ao seu cúmplice pode ser anulada pelo outro cônjuge, ou por seus herdeiros necessários, até dois anos depois de dissolvida a sociedade conjugal (BRASIL, 1916).

O CC/1916 foi revogado somente em 2002, com o advento do CC/2002. Entretanto, já havia tentativas constantes e dispostas em legislaçôes apartadas que buscavam modernizar o regime, de modo a incluir as novas organizaçóes familiares que surgiram com a mudança de valores sociais, incluindo-se a concubina e os filhos havidos fora do casamento. Tais mudanças estão demonstradas a seguir:

Art. 21 do Decreto-lei n. 7.036/1944. [...] Parágrafo único.

Para os efeitos deste artigo, não haverá distinção entre os filhos de qualquer condição, bem como terá os mesmos benefícios do cônjuge legítimo, caso este não exista ou não tenha direito ao benefício, a companheira mantida pela vítima, uma vez que haja sido declarada como beneficiária em vida do acidentado, na carteira profissional, no registro de empregados, ou por qualquer outro ato solene de manifestação de vontade (BRASIL, 1944). 
A Lei n. 4.297/1963 também disciplinava neste sentido:

Art. $3^{\circ}$ da Lei n. 4.297/1963. Se falecer o ex-combatente segurado de Instituto de Aposentadoria e Pensóes ou Caixa de Aposentadoria e Pensôes, aposentado ou não, será concedida, ao conjunto de seus dependentes, pensão mensal, reversível, de valor total igual a $70 \%$ (setenta por cento) do salário integral realmente percebido pelo segurado e na seguinte ordem de preferência:

d) à companheira, desde que com o segurado tenha convivido maritalmente por prazo não inferior a 5 anos e até a data de seu óbito $[\ldots]$.

[...] Em caso de acidente do trabalho ou de transporte, a concubina tem direito de ser indenizada pela morte do amásio, se entre eles não havia impedimento para o matrimônio (BRASIL, 1963).

A edição da Lei n. 6.515/1977, que possibilitou o divórcio no Brasil, serviu como um divisor de águas para o caráter indissolúvel do casamento, representando uma abertura de precedentes para a verificação de novas formas de família.

As decisões do STF acompanharam as mudanças sociais e começaram a identificar as concubinas como merecedoras do direito à divisão de bens adquiridos por esforço comum, resultando na Súmula 380 do STF que dispôs: "Comprovada a existência de sociedade de fato entre os concubinos, é cabível a sua dissolução judicial, com a partilha do patrimônio adquirido pelo esforço comum” (BRASIL, 1964).

Naquele período, não obstante o avanço no reconhecimento de direitos às concubinas, a maioria da doutrina e da jurisprudência vislumbrava que a sociedade conjugal deveria ser regulamentada no direito das obrigaçóes. Assim, o dever de prestar alimentos à ex-concubina sempre foi de difícil reconhecimento, até o advento da Constituição Federal de 1988 (CF/1988), que colocou fim às controvérsias e estabeleceu a união estável como entidade familiar passível de total proteçáo pelo Estado. Assim prelecionou o art. 226, $₫ 3^{\circ}$, da $\mathrm{CF} / 1988$ : “a família, base da sociedade, tem especial proteção do Estado. [...] $₫ 3^{\circ}$ Para efeito da proteção do Estado, é reconhecida a união estável entre o homem e a mulher como entidade familiar, devendo a lei facilitar sua conversão em casamento" (BRASIL, 1988).

A CF/1988 admitiu uma realidade social que havia muitos anos clamava por uma tutela que náo fosse apenas atendida por leis isoladas no ordenamento e por jurisprudência específica. 
Cumpre salientar que atualmente, no Brasil, as uniôes estáveis representam mais de $1 / 3$ dos casais. Segundo o Instituto Brasileiro de Geografia e Estatística (IBGE), em dez anos esse número subiu de $28,6 \%$ para 36,4\%. Segundo a pesquisa, essa união seria mais comum nas classes mais baixas, levando-se em conta os altos custos que conduzem à celebração de um casamento, conforme a Associação dos Registradores de Pessoas Naturais do Estado de São Paulo (ARPEN-SP): as classes com menor condição financeira "representa[m] 48,9\% das ligaçóes na população com rendimento de até meio salário mínimo, e entre brasileiros de até 39 anos. Conforme o rendimento do casal aumenta, a representatividade da uniáo estável consensual diminui" (ARPEN-SP, 2014).

Para acompanhar a nova ordem constitucional, o CC/2002 tentou tutelar de forma mais ampla a união estável, mas acabou, em certos pontos, retrocedendo, visto que em determinadas situaçôes o companheiro supérstite se torna parte prejudicada na partilha da herança. No mesmo sentido preceitua Hironaka:

[...] o companheiro sobrevivente participará da sucessão do outro apenas quanto aos bens adquiridos onerosamente pelo 'de cujus' na vigência da união estável, ou seja, a concorrência ocorrerá justamente quanto aos bens sobre os quais o companheiro já é meeiro. Dessa forma, se o companheiro falecido não tivesse amealhado quaisquer bens na constância da Uniấo Estável, mas possuísse um enorme patrimônio anterior, o companheiro sobrevivente restará afastado da sucessão, sejam quem forem os herdeiros eventualmente existentes (HIRONAKA, 2007, p. 107).

Conclui-se, então, que o Direito Brasileiro, ao longo de sua evolução, sempre refletiu os entendimentos sociais de modo a adequar os valores jurídicos aos populares. A relação entre sociedade e direito é ainda mais íntima na matéria aqui relatada, por tratar de reconhecimento de laços afetivos e emocionais, bem como das noçôes sociais de família e da constituição de seu patrimônio. Nota-se, entấo, a flagrante dissonância do CC/2002 com os valores da época em que se inicia sua vigência: não obstante a noção social de que a família sob união estável tinha os mesmos laços e, portanto, os mesmos direitos da família constituída sob o casamento civil, o Código, que seria considerado novo, não se adequava a essas percepçóes sociais.

\section{Sustentabilidade pela dignidade da pessoa humana}

Não se apresentou, ainda, questão jurídica que não tivesse íntima ligaçáo com o valor constitucional da dignidade da pessoa humana, consagrado no 
ordenamento nacional na CF/1988 e no ordenamento internacional, sendo proclamado em diversos instrumentos. Assim, não se furta o trabalho de fazer breves consideraçóes acerca da nova partilha em caso de sucessáo por morte da família formada sob uniâo estável e o referido princípio.

$\mathrm{O}$ direito à sucessão e à dignidade da pessoa humana constituem cláusulas pétreas nos arts. $5^{\circ}$, inc. XXX, e $1^{\circ}$, inc. III, respectivamente, da CF/1988. A transmissão de herança tem como principal fundamento assegurar àqueles que se relacionaram com o falecido por laços afetivos e familiares, o patrimônio e a subsistência, além de representar reforço à propriedade privada, também prevista como direito constitucional, não obstante algumas restriçóes atreladas à sua função social.

É notável o laço entre a transmissão de bens e a dignidade da pessoa humana. Não obstante as tentativas do Estado de prover a seus cidadãos suas necessidades básicas, a garantia de moradia e transmissão de bens do de cujus aos que dele dependem - ou não - assegura que permaneçam estes com a mesma dignidade que tinham quando estava o proprietário vivo.

A relação fica ainda mais clara quando se nota que a constituição do patrimônio tem como objetivo maior assegurar qualidade de vida, e a transmissão dos bens do falecido permite aos supérstites usufruir dessa qualidade. $\mathrm{O}$ direito de habitaçáo, garantido ao cônjuge ou companheiro supérstite quando o outro falece, é medida necessária a fim de permitir que a família permaneça com a segurança patrimonial que lhe era ofertada.

Discorre-se, aqui, sobre a inovadora relação do que foi apresentado com a sustentabilidade. A doutrina de vanguarda afirma que a sustentabilidade é demasiado ampla para estar contida somente na ideia de preservação ambiental e os demais assuntos relacionados ao meio ambiente em sentido mais restrito. Conforme Coelho e Mello:

Redução da desigualdade e fomento do diálogo (desenvolvimento democrático), garantia de patamares mínimos e progressivos de qualidade de vida (desenvolvimento social), e racionalização das relaçóes do homem com os recursos naturais e ecossistemas (desenvolvimento ambiental) somam-se à sustentabilidade intergeracional e formam, assim, o tripé conceitual complementar do desenvolvimento sustentável como complexo conceitual (COELHO; MELLO, 2011, p. 13).

Com relação à sustentabilidade, destaca-se que ela apresenta diversas dimensóes. Para fins de recorte metodológico, adotar-se-á na presente pesquisa apenas cinco dimensóes, a fim de explicar o direito sucessório sustentável. 
Destacam-se, dessa forma, as dimensôes ética, social, econômica, jurídico-política e ambiental.

A dimensão ética caracteriza-se pelo comprometimento das gerações atuais referente à preservação dos recursos naturais para as futuras geraçóes, "a fim de perpetuar uma herança marcada não só pela continuidade de um mundo qualitativamente habitável, como também pelo plexo de solidariedade e fraternidade intergeracional" (GOMES; OLIVEIRA, 2018, p. 214).

A dimensão social, por sua vez, destaca a noção de que uma sociedade sustentável deve prezar pela garantia dos direitos fundamentais dos indivíduos, sendo o desenvolvimento sustentável visto como "um catalisador para garantia de direitos essenciais inerentes à qualidade de ser humano e que estáo positivados constitucionalmente" (GOMES; OLIVEIRA, 2018, p. 214).

A dimensão econômica caminha no sentido da necessidade de progresso e crescimento econômico, aliado à preservação ambiental. Dessa forma, deve haver o desenvolvimento sustentável, com vistas a conservar os recursos naturais atualmente existentes, promovendo, ao mesmo tempo, o crescimento da economia. A dimensão jurídico-política mostra-se de extrema importância, pois:

[...] visa a efetivar e desenvolver os direitos fundamentais das presentes e futuras geraçóes, com o objetivo de asseverar e reforçar o plexo de desenvolvimento consubstanciado na preservação e proteção ambiental, sem, contudo, perder de vista a promoção social, o respeito à dignidade humana e aos direitos humanos, a melhor e adequada distribuição da renda e os conceitos de origem ética, que são vertentes indissociáveis do conceito de sustentabilidade (GOMES; FERREIRA, 2017, p. 96).

Por fim, "quer-se aludir, com a dimensão [...] ambiental da sustentabilidade, ao direito das geraçóes atuais, sem prejuízo das futuras, ao ambiente limpo, em todos os aspectos (meio ecologicamente equilibrado, como diz o art. $225 \mathrm{da} \mathrm{CF}$ )" (FREITAS, 2016, p. 68).

A sustentabilidade e a dignidade da pessoa humana que se relacionam à sucessão de bens na união estável estáo ligadas ao desenvolvimento democrático, por tratar-se de participação social e representação de valores dessa sociedade no âmbito jurídico, e do desenvolvimento social, por estar relacionada aos "patamares mínimos e progressivos de qualidade de vida” (COELHO; MELLO, 2011, p. 13). Em sentido equivalente, Freitas estabelece que a sustentabilidade é o

[...] princípio constitucional que determina, com eficácia direta e imediata, a responsabilidade do Estado e da sociedade pela 
concretização solidária do desenvolvimento material e imaterial, socialmente inclusivo, durável e equânime, ambientalmente limpo, inovador, ético e eficiente, no intuito de assegurar, preferencialmente de modo preventivo e precavido, no presente e no futuro, o direito ao bem-estar (FREITAS, 2016, p. 43).

Nesse diapasão, há também que se considerar a dignidade da pessoa humana como norte a orientar o ordenamento jurídico brasileiro. Esse princípio, conforme Coelho e Mello (2011, p. 7):

[...] pressupóe respeito à identidade cultural, respeito à história de vida de cada sujeito e de cada tradição. Esse é o grande desafio da tarefa de aproximaçấo dos sistemas jurídicos mundiais rumo a uma implementação dos direitos humanos como bases de sustentação e meta final de todos eles. A alteridade - reconhecimento do outro, do diferente, como igualmente digno - constitui elemento fundamental da Justiça Universal Concreta como um ideal realizável. Assim sendo, a compreensão do Direito no plano de uma universalidade inclusiva surge como tarefa indispensável à busca por efetividade dos direitos fundamentais da pessoa humana e da concreçáo do conceito de Direito [...].

Assim, ao identificar os valores sociais no que se refere ao reconhecimento da união estável como uma forma tão legítima quanto o casamento civil para a constituição de família e também para a partilha de bens quando da morte de um companheiro, o STF promove a alteridade e reafirma a identidade cultural da sociedade brasileira, reforçando a dignidade da pessoa humana no âmbito jurídico. "Nessa ótica, para se alcançar o pleno desenvolvimento pautado na sustentabilidade é imprescindível que o direito à dignidade da pessoa humana seja respeitado em todas as relaçóes cotidianas, desde as mais simples às mais complexas" (GOMES; FERREIRA, 2017, p. 97).

Nota-se, entáo, que, para que o ordenamento consiga efetivar, em algum grau, a dignidade da pessoa humana, tem de estar de acordo com os valores da sociedade sob a qual ele incide. Assim expóem Staffen e Santos sobre a importância da identidade entre os cidadáos e o ordenamento jurídico:

A Constituição de letra viva é aquela cujo resultado é fruto de todos os intérpretes de uma sociedade aberta. Por isso, o aspecto jurídico é apenas um dos elementos da Constituição como cultura. A aceitação de uma Constituiçâao pressupóe normas jurídicas, mas isso não constitui, de per si, uma garantia daquilo que o 
Estado constitucional esteja de fato realizando, porque é preciso averiguar se há consenso em âmbito constitucional, se há correspondência entre texto constitucional e a cultura política do povo, se os cidadãos se sentem identificados com a Constituição (STAFFEN; SANTOS, 2016, p. 267).

Dessa maneira, ao analisar o reconhecimento social da união estável como uma forma igualitária ao casamento para constituição de núcleo familiar, bem como as legislaçóes infraconstitucionais anteriores ao CC/2002 e a proposta constitucional de reconhecer a união estável como entidade familiar, não há que se falar em sucessão diferenciada entre cônjuge e companheiro. É necessário reafirmar que essa disposição infraconstitucional - prevista no artigo declarado inconstitucional pelo STF - náo condiz com a identidade cultural do cidadão brasileiro desde a época do início da vigência do CC/2002, principalmente porque tal norma foi elaborada ainda sob o regime militar.

\section{O Recurso Extraordinário n. 878.694}

Distribuído em 26/03/2015, o RE n. 878.694 teve sua repercussão geral declarada em 17/04/2015, data em que o plenário decidiu, por unanimidade, que o recurso tinha relevância jurídica, histórica e social suficiente para ser julgado pelo STF. Tratava o RE n. 878.694 de inventário de um homem que vivia em uniáo estável com Maria de Fátima Ventura por nove anos. Com seu falecimento, a partilha de seus bens foi determinada pelo art. 1.790 do CC/2002 e instruía que, como tinha irmáos ainda vivos, eles herdariam $2 / 3$ de seu patrimônio, e a companheira, somente $1 / 3$. Se fossem casados, a recorrente teria direito à totalidade da herança.

Em primeira instância, o magistrado afastou a incidência do art. 1.790 do CC/2002 e "reconheceu à companheira do falecido o direito à totalidade da herança, o real de habitação, e a legitimidade para receber a indenização do seguro de vida" (BRASIL, 2015), conforme transcrição do acórdão que reconheceu a repercussão geral no caso. O TJMG proferiu o acórdão do caso. Transcreve-se aqui a ementa:

EMENTA: APELAÇÃO CÍVEL. RECONHECIMENTO DE UNIÃO ESTÁVEL. PARTILHA. DIREITOS SUCESSÓRIOS DA COMPANHEIRA. ARTIGO 1.790, III, DO CÓDIGO CIVIL. CONSTITUCIONALIDADE. RECONHECIMENTO PELO ÓRGÃO ESPECIAL DESTE TRIBUNAL DE JUSTIÇA, DO DIREITO DE 
A COMPANHEIRA SOBREVIVENTE HERDAR TÃO SOMENTE OS BENS ADQUIRIDOS ONEROSAMENTE DURANTE A UNIÃO ESTÁVEL, EM CONCORRÊNCIA COM OS PARENTES COLATERAIS DE SEGUNDO GRAU, EXCLUÍDOS, PORTANTO, OS BENS PARTICULARES. RECURSO CONHECIDO E PROVIDO (MINAS GERAIS, 2011).

Tal partilha parece estranha ao homem médio, visto que, por sua ausência de contato com o direito, compreende pertencer todo o patrimônio do falecido à companheira, conforme seria feita a divisão se fossem casados. Essa noção de divisão de bens decorre do reconhecimento social com que contam os companheiros de que estáo unidos como se fossem casados e, portanto, dignos de receber o mesmo tratamento. A seguir, busca-se verificar se os valores sociais foram relevantes para que o STF proferisse outra decisão para a partilha.

Conforme as noçôes expostas com relação à dignidade da pessoa humana, sustentabilidade e a matéria aqui tratada, qual seja, direito sucessório, nota-se que a decisão proferida pelo egrégio TJMG pouco reflete os valores e as identidades culturais nacionais. Dessa forma, não há que se falar em incidência dos princípios constitucionais previamente citados, visto que há mera aplicação de dispositivo legal, qual seja, o art. 1.790 , inc. III, do CC/2002, ignorando os impactos sociais dele decorrentes e sua falta de relaçáo axiológica com os cidadãos nacionais.

Assim, há de se concordar com a necessidade de reforma da decisão proferida, visto que ela é o reflexo inconstitucional de uma norma posteriormente considerada como tal pelos diversos motivos já expostos, cujo principal é a ausência de relação da norma com as noções sociais de família e partilha de bens após a morte do companheiro. Analisar-se-á, no próximo tópico, se o STF se utiliza das noçôes aqui expostas ao optar pela inconstitucionalidade do art. 1.790, inc. III, do CC/2002.

\section{0 julgamento}

A recorrente buscou, com a interposição do recurso, que fosse a ela concedida a partilha nos termos do art. 1.829 do CC/2002, que trata da sucessão para o cônjuge, não para o companheiro, arguindo a inconstitucionalidade do art. 1.790, inc. III, do CC/2002 como questão prejudicial ao mérito recursal, em verdadeiro controle difuso de constitucionalidade. Apresentou como fundamentos para sua tese o art. 102, inc. III, $a$, da CF/1988, por entender que tal decisão proferida pelo TJMG fere disposição constitucional, a saber, o art. 5º, inc. I, da CF/1988, 
que trata da igualdade entre homens e mulheres, e o art. $226, \$ 3^{\circ}$, da $\mathrm{CF} / 1988$, que assim dispóe: "a família, base da sociedade, tem especial proteção do Estado" (BRASIL, 1988), e no $\$ 3^{\circ}$ : "para efeito da proteção do Estado, é reconhecida a união estável entre o homem e a mulher como entidade familiar, devendo a lei facilitar sua conversão em casamento" (BRASIL, 1988). Como fundamentos fáticos, a recorrente alegou que os irmãos não eram próximos do falecido, ao passo que ela foi sua companheira e estava com ele diariamente, auxiliando na construção e na preservação do patrimônio do de cujus.

O recurso teve como ministro relator Luís Roberto Barroso. Manifestaram-se como amici curiae o Instituto Brasileiro de Direito de Família (IBDFAM) e o Instituto dos Advogados Brasileiros (IAB), na pessoa da Dra. Ana Luiza Maia Nevares, e a Associação de Direito de Família e das Sucessôes (ADFAS), representada pela Dra. Regina Beatriz Tavares da Silva.

A Dra. Nevares, representante do IAB, ressaltou que o CC/2002, não obstante a vigência recente, é um projeto de 1975 , período em que ainda vigorava a noção exclusiva de família como pessoas unidas em matrimônio. Concordou com esse argumento o Ministro Luís Roberto Barroso, relator do recurso, por entender que não há que se diferenciar o tratamento entre companheiros e cônjuges, criando uma "hierarquização" de famílias, concedendo aos cônjuges tratamento mais favorável. O ministro reforçou que a diferenciação entre companheiros e cônjuges se dá pela solenidade revestida ao casamento e a segurança jurídica dela decorrente, não tendo tal solenidade relaçáo com a partilha de bens após o falecimento de companheiro ou cônjuge. A partilha, para o ministro, nos termos do art. 1.790, inc. III, do CC/2002 está demasiado atrelada à noção de família antiquada vigente à época de redação do dispositivo supramencionado.

Resta retratar, no entanto, que normas vigentes na década de 1990, quais sejam, as Leis n. 8.971/1994 e 9.278/1996, já garantiam aos companheiros a sucessão conforme as disposiçôes referentes ao cônjuge. Nota-se, então, que as disposiçôes do CC/2002 representam um retrocesso nos direitos concedidos àqueles que estão em união estável, cumprindo ressaltar a impossibilidade de retrocesso social, prevista constitucionalmente em matéria de direito fundamental, cuja sucessão o é.

Foi nesse sentido que o STF julgou, no dia 10/05/2017, com repercussão geral, os temas de n. 809 e 498, dando provimento a partir do voto do ministro relator aos Recursos Extraordinários de n. 878.694/MG e n. 646.721/RS, respectivamente, a fim de reconhecer, de maneira incidental, o art. 1.790 do CC/2002 como inconstitucional, declarando, consequentemente, o direito dos recorrentes a ter aplicado em seu caso o regime jurídico estabelecido no art. 1.829 
do CC/2002. A tese firmada deu-se nos termos que seguem: "é inconstitucional a distinção de regimes sucessórios entre cônjuges e companheiros prevista no art. 1.790 do CC/2002, devendo ser aplicado, tanto nas hipóteses de casamento quanto nas de união estável, o regime do art. 1.829 do CC/2002" (BRASIL, 2017).

Nesse sentido, o STF declarou o dispositivo 1.790 do CC/2002 inconstitucional, de forma incidente, equiparando os tratamentos dispendidos aos regimes jurídicos dos companheiros aos dos cônjuges, estendendo a aplicação do art. 1.829 do CC/2002, que era aplicada apenas aos cônjuges, também aos companheiros que vivem em união estável. O Recurso Extraordinário n. 878.694/ MG demonstra a convivência da demandante com seu companheiro. No que toca à união estável, ela durou mais de nove anos, sendo que, após esse período, seu companheiro faleceu sem que houvesse deixado testamento. Ele também não tinha descendentes e ascendentes, restando em vida somente três irmãos e a companheira recorrente.

Foi com base nesse cenário que o Tribunal de origem, TJMG, aplicou o art. 1.790, inc. III, do CC/2002 ao caso, limitando os direitos sucessórios da companheira que faria jus a $1 / 3$ dos bens adquiridos na constância da união a título oneroso, sendo que os bens particulares do falecido iriam integralmente aos irmãos, em contraponto ao entendimento destinado aos cônjuges que, no caso, iria reservar a totalidade dos bens à companheira.

Torna-se necessário, no momento, verificar a trajetória do entendimento firmado pelo STF que resultou na decisão referida. Nota-se, inicialmente, que em 31/08/2016 sete votos foram prolatados conforme voto proferido pelo Ministro Relator Luíz Roberto Barroso, a fim de ser declarado inconstitucional o art. 1.790 do CC/2002.

A Ministra Cármen Lúcia alegou que as mulheres, como companheiras, serão as mais beneficiadas com a declaração da inconstitucionalidade do art. 1.790 do CC/2002, visto que a expectativa de vida feminina é maior e, em muitos casos, são as companheiras dependentes financeiramente dos companheiros, motivo este que também fundamenta a repercussão geral do caso, já que muitas delas, herdando apenas fração do patrimônio do companheiro, poderiam acabar em desamparo.

O Ministro Celso de Mello entendeu que a união estável e o casamento se fundam "nos vínculos de solidariedade, amor e de projetos de vida em comum [e, por isso,] hão de merecer o integral amparo do Estado" (BRASIL, 2017).

Os ministros que votaram de acordo com o Relator foram Luiz Edson Fachin, Rosa Weber, Teori Zavascki, Luiz Fux, Celso de Mello e Cármem Lúcia. $\mathrm{O}$ julgamento, no entanto, não foi encerrado na época em razão do pedido de 
vista realizado pelo Ministro Dias Tofolli.

Após o pedido de vista, o Ministro Dias Toffoli manifestou-se pela constitucionalidade do art. 1.790 do CC/2002, sob o argumento de que o exame diferenciado entre cônjuges e companheiros, decorrentes de casamento e união estável, respectivamente, decorre de justificativa constitucional para tanto.

O julgamento não foi concluído mesmo após o voto do Ministro Dias Toffoli, tendo em vista que o Ministro Marco Aurélio pediu vista, requerendo que o Recurso Extraordinário n. 646.721/RS fosse apensado aos autos em análise, a fim de que um somente julgamento fosse realizado, na medida em que este último também envolvia a união estável entre companheiros do mesmo sexo, união homoafetiva, em cujo recurso o referido ministro figurava na relatoria. Os julgamentos dos dois processos foram retomados em maio de 2017. No julgamento do Recurso Extraordinário n. 646.721/RS, o ministro relator entendeu não haver diferença entre as uniốes homo e heteroafetivas, aplicando o entendimento firmado na Arguição de Descumprimento de Preceito Fundamental (ADPF) n. 132/RJ/2011, em que se reconheceu o instituto jurídico da uniáo homoafetiva.

Entretanto, no que diz respeito à equiparação do tratamento dispendido para uniâo estável e casamento, ele considerou a diferenciação constitucional, manifestando conformidade com a preservação do art. 1.790 do CC/2002. Acompanhando seu voto, seguiu o Ministro Ricardo Lewandowski, que votou pela constitucionalidade do art. 1.790 do CC/2002, na medida em que o art. 226, $\$ 3^{\circ}$, da $\mathrm{CF} / 1988$, justificaria a diferenciação de tratamento entre a união estável e o casamento, uma vez que a pessoa optou pelo regime precário.

O entendimento prevalecente foi no sentido da equiparaçáo sucessória entre a uniáo homoafetiva e a heteroafetiva, bem como da inconstitucionalidade do art. 1.790 do CC/2002, firmado pelos ministros Luís Roberto Barroso, Cármen Lúcia, Rosa Weber, Gilmar Mendes, Luiz Edson Fachin, Luiz Fux e Alexandre de Moraes. Salienta-se que este último não teve como votar no processo que tratou acerca da inconstitucionalidade do art. 1.790 do CC/2002, pois, à época, quem ocupava o cargo era o então Ministro Teori Zavascki, proferindo entendimento apenas no processo relativo à sucessão na união estável homoafetiva. O Informativo n. 864 apontou o entendimento firmado pelo STF, conforme segue:

O Supremo Tribunal Federal (STF) afirmou que a Constituição prevê diferentes modalidades de família, além da que resulta do casamento. Entre essas modalidades, está a que deriva das unióes estáveis, seja a convencional, seja a homoafetiva. Frisou que, após a vigência da Constituiçẫo de 1988, duas leis ordinárias equipararam os regimes jurídicos sucessórios do casamento e da união 
estável (Lei 8.971/1994 e Lei 9.278/1996). O Código Civil, no entanto, desequiparou, para fins de sucessão, o casamento e as unióes estáveis. Dessa forma, promoveu retrocesso e hierarquização entre as famílias, o que não é admitido pela Constituição, que trata todas as famílias com o mesmo grau de valia, respeito e consideração. O art. 1.790 do mencionado código é inconstitucional, porque viola os princípios constitucionais da igualdade, da dignidade da pessoa humana, da proporcionalidade na modalidade de proibiçấo à proteçăo deficiente e da vedação ao retrocesso (BRASIL, 2017).

No que tange ao julgamento do Recurso Extraordinário n. 878.694/MG, os ministros Ricardo Lewandowski e Marco Aurélio sustentaram os mesmos entendimentos do processo anterior, entendendo pela constitucionalidade do art. 1.790 de CC/2002, seguindo tal entendimento o Ministro Dias Toffoli. Para os ministros, o dispositivo apontado como inconstitucional não estabelece uma hierarquia entre o casamento e a união estável, acentuando tão somente as duas instituiçôes como formas distintas de entidade familiar, afirmando deverem ser respeitadas as escolhas dos casais que optam por constituir união estável em detrimento do matrimônio. No entanto, foi firmado o entendimento do Informativo n. 864 .

O Supremo Tribunal Federal afirmou que a Constituição contempla diferentes formas de família, além da que resulta do casamento. Nesse rol incluem-se as famílias formadas mediante união estável. Portanto, não é legítimo desequiparar, para fins sucessórios, os cônjuges e os companheiros, isto é, a família formada por casamento e a constituída por união estável. Tal hierarquização entre entidades familiares mostra-se incompatível com a Constituição. O art. 1.790 do Código Civil de 2002, ao revogar as Leis 8.971/1994 e 9.278/1996 e discriminar a companheira (ou companheiro), dando-lhe direitos sucessórios inferiores aos conferidos à esposa (ou ao marido), entra em contraste com os princípios da igualdade, da dignidade da pessoa humana, da proporcionalidade na modalidade de proibição à proteçáo deficiente e da vedação ao retrocesso (BRASIL, 2017).

Nota-se, assim, que as decisóes mencionadas demonstram grande avanço em matéria sucessória e alteração no entendimento que garante tratamento desigual e hierarquizado às duas concepçóes de família. Com esse entendimento, a interpretação da matéria foi unificada, consistindo em precedente a ser aplicado 
nas decisôes que venham a ser proferidas após sua publicação, aplicando à união estável o mesmo dispositivo legal aplicado ao casamento.

A CF/1988 contempla diferentes formas de constituição familiar, razão pela qual o exame diferenciado entre elas viola o disposto constitucionalmente. Ademais, o art. 1.790 do CC/2002, ao garantir direitos diferentemente inferiores ao companheiro em detrimento dos conferidos ao cônjuge, revela o desrespeito a princípios constitucionais que perpassam todo o ordenamento jurídico, entre os quais se destacam os princípios da igualdade, da dignidade da pessoa humana, da vedação ao retrocesso, da sustentabilidade, da proporcionalidade, como forma de vedação ao amparo deficiente, restando configurada a inconstitucionalidade do referido dispositivo.

Com base nesses princípios é que destaca a ementa da decisão elaborada pelo ministro relator, Luís Roberto Barroso, cujo resultado foi a inconstitucionalidade do dispositivo supramencionado:

Direito constitucional e civil. Recurso extraordinário. Repercussão geral. Inconstitucionalidade da distinção de regime sucessório entre cônjuges e companheiros. 1. A Constituiçăo brasileira contempla diferentes formas de família legítima, além da que resulta do casamento. Nesse rol incluem-se as famílias formadas mediante uniáo estável. 2. Não é legítimo desequiparar, para fins sucessórios, os cônjuges e os companheiros, isto é, a família formada pelo casamento e a formada por uniâo estável. Tal hierarquização entre entidades familiares é incompatível com a Constituição de 1988. 3. Assim sendo, o art. 1790 do Código Civil, ao revogar as Leis n.s 8.971/94 e 9.278/96 e discriminar a companheira (ou o companheiro), dando-lhe direitos sucessórios bem inferiores aos conferidos à esposa (ou ao marido), entra em contraste com os princípios da igualdade, da dignidade humana, da proporcionalidade como vedaçáo à proteçáo deficiente, $\mathrm{e}$ da vedaçáo do retrocesso. 4 . Com a finalidade de preservar a segurança jurídica, o entendimento ora firmado é aplicável apenas aos inventários judiciais em que não tenha havido trânsito em julgado da sentença de partilha, e às partilhas extrajudiciais em que ainda não haja escritura pública. 5. Provimento do recurso extraordinário. Afirmação, em repercussão geral, da seguinte tese: 'No sistema constitucional vigente, é inconstitucional a distinção de regimes sucessórios entre cônjuges e companheiros, devendo ser aplicado, em ambos os casos, o regime estabelecido no art. 1.829 do CC/2002' (BRASIL, 2017, grifo nosso). 
A tese de inconstitucionalidade levantada por Barroso funda-se no argumento de que o CC/1916, pautado pelas Leis n. 8.971/1994 e 9.278/1996, previa condição mais favorável ao companheiro em comparação ao CC/2002, verificando, assim, um retrocesso em matéria sucessória e social no Brasil.

Tal conclusão se deu em razão de no art. 1.603 do CC/1916 haver a equivalência do casamento à união estável em se tratando de matéria sucessória, já que o companheiro estava abarcado no rol do referido artigo, assim como o cônjuge, restando, então, configurado o retrocesso social.

O Ministro Luís Roberto Barroso sustentou, ainda, que, embora o art. 226 da CF/1988 preveja a modificação da uniáo estável em casamento, ele não exala prioridade por este em prejuízo daquela, não podendo ser configurada qualquer tipo de hierarquização dos institutos familiares. Explicou o ministro que se trata de previsão constitucional que visa assegurar maior segurança jurídica às relaçôes afetivas e sociais, vez que formalizadas. Entretanto, no que pese a distinção relativa à formalidade na instituição do matrimônio, ela não deve ser considerada razão suficiente para atribuir tratamento diferenciado ao companheiro em respeito ao princípio da dignidade da pessoa humana.

Em análise atenta ao voto do ministro, o motivo para a declaração de inconstitucionalidade foi a violação dos princípios da proporcionalidade, como forma de vedação à proteção deficiente, da dignidade da pessoa humana e da proibição ao retrocesso social.

O ministro ainda sustentou que a dignidade da pessoa humana se mostra como um princípio essencial responsável por estabelecer que todos os seres merecem ser tratados com consideração e respeito, já que ostentam igual valor. É com base nessa perspectiva que: "verifica-se a proibição de discriminaçóes ilegítimas, sobretudo, acerca das diferentes formas de constituição de família, considerando que o direito sucessório brasileiro determina como legítimo e protege os diversos arranjos familiares" (LUCA, 2018, p. 45). Trata-se de aplicação imediata da força normativa desse princípio constitucional, em verdadeira análise pós-positivista ou neoconstitucionalista.

$\mathrm{O}$ princípio da dignidade da pessoa humana deve permear todo o ordenamento jurídico, seja concernente às normas infraconstitucionais, seja às normas constitucionais. Tal princípio, conforme Gagliano e Pamplona (2016, p. 83), "traduz um valor fundamental de respeito à existência humana, segundo as suas possibilidades e expectativas, patrimoniais e afetivas, indispensáveis à sua realização pessoal e à busca da felicidade".

Dessa forma, o exame diferenciado a cônjuges e companheiros, conforme o art. 1.790 do CC/2002, viola o princípio da dignidade, vez que náo possibilita 
a efetivação de direitos sucessórios de modo igualitário. Percebe-se que: "em garantia a uma vida digna e satisfatória, em nível constitucional é fundamental a equiparação, por isto concernem as prerrogativas e garantias que o cônjuge possui, sendo plenamente meritório a proporção de direitos ao companheiro (a)" (ARAÚJO et al., 2018, p. 7).

No que tange à violação da proporcionalidade, ela se faz presente ao se verificar a proteção estatal insuficiente quando da configuração de princípios constitucionais previstos e direitos constitucionalmente garantidos, como se constata no que concerne à união estável. É nesse sentido que se destaca o entendimento do Ministro Relator em seu voto:

A ideia nesse caso é a de que o Estado também viola a Constituição quando deixa de agir ou quando não atua de modo adequado e satisfatório para proteger bens jurídicos relevantes [...]. No caso em discussão, a violação à proporcionalidade como vedaçấo à proteção deficiente é bastante evidente. Como se viu, o conjunto normativo resultante do art. 1.790 do Código Civil veicula uma proteçấo insuficiente ao princípio da dignidade da pessoa humana em relação aos casais que vivem em uniâo estável. A depender das circunstâncias, tal regime jurídico sucessório pode privar o companheiro supérstite dos recursos necessários para seguir com sua vida de forma digna. Porém, a deficiência da atuaçáo estatal em favor da dignidade humana dos companheiros não é justificada pela tutela de nenhum outro interesse constitucional contraposto. Conforme já analisado, não se pode defender uma preferência constitucional ao casamento para justificar a manutenção da norma do Código Civil menos protetiva da união estável em relação ao regime sucessório aplicável. À luz da Constituição de 1988, não há hierarquia entre as famílias e, por isso, não se pode desigualar o nível de proteção estatal a elas conferido (BRASIL, 2017).

No que se refere à vedação ao retrocesso social, sustentou o relator que a sucessão anterior ao CC/2002 apresentava situação mais favorável ao companheiro do que a legislação vigente, pois era marcada pela presença de duas outras leis que garantiam equiparação do casamento à união estável. Nesse sentido, destaca-se:

Art. $1^{\circ}$ É reconhecida como entidade familiar a convivência duradoura, pública e contínua, de um homem e uma mulher, estabelecida com objetivo de constituição de família. [...] 
Art. $7^{\circ}$ Dissolvida a uniáo estável por rescisão, a assistência material prevista nesta Lei será prestada por um dos conviventes ao que dela necessitar, a título de alimentos. Parágrafo único. Dissolvida a união estável por morte de um dos conviventes, o sobrevivente terá direito real de habitação, enquanto viver ou não constituir nova união ou casamento, relativamente ao imóvel destinado à residência da família (BRASIL, 1996).

Art. $2^{\circ}$ As pessoas referidas no artigo anterior participaráo da sucessão do(a) companheiro(a) nas seguintes condições: [...] III - na falta de descendentes e de ascendentes, o(a) companheiro(a) sobrevivente terá direito à totalidade da herança (BRASIL, 1994).

Assim dispõe Gonçalves (2019, p. 135) sobre as referidas Leis:

A Lei n. 8.971, de 29 de dezembro de 1994, que regulou o direito dos companheiros a alimentos e a sucessão, e a Lei n. 9.278, de 10 de maio de 1996 , que regulamentou o art. $226, \$ 3^{\circ}$, da Constituiçấo Federal, reconhecendo a uniâo estável entre o homem e a mulher como entidade familiar, asseguraram aos companheiros, dentre outros direitos, o de herdar.

Tal princípio pode ser conceituado por Gagliano e Pamplona Filho (2016, p. 89), que preceituam: "desenvolvido genialmente por J. J. Gomes Canotilho, esse superior princípio traduz a ideia de que uma lei posterior não pode neutralizar ou minimizar um direito ou uma garantia constitucionalmente consagrado".

Ainda referente a esse princípio, o art. 1.790 do CC/2002 dispóe literalmente uma distinção entre os direitos sucessórios garantidos aos cônjuges e aos companheiros. Nota-se uma violação à $\mathrm{CF} / 1988$, tendo em vista que ela estabelece a igualdade de tratamento, e o CC/2002 posterior à CF/1988 retrocede o entendimento firmado constitucionalmente.

Dessa forma, configura-se o retrocesso da norma cível aplicada, vez que sucede de maneira desproporcional aos herdeiros, sendo que a partilha recai apenas sobre os bens adquiridos onerosamente na constância da união, caracterizada pela concorrência do companheiro com parentes de $4^{\circ}$ grau.

A I Jornada de Direito de Família, proposta pela Corregedoria Geral de Justiça do Tribunal de Justiça da Bahia (TJBA), concretizou o Enunciado n. 13, como se segue: 
Enunciado n. 13 - O art. 1790 do Código Civil viola o superior princípio da vedação ao retrocesso e desrespeita a condição jurídica da (o) companheira (o) como integrante de um núcleo familiar equiparado àquele formado pelo casamento, razão por que padece de absoluta inconstitucionalidade (BRASIL, 2011).

Nesse sentido, verifica-se que o tema tratado já passou por ampla discussão, tendo sido levantado em reunião das Jornadas de Direito de Família, e já ali se mostrava inconstitucional por violar princípios constitucionalmente garantidos que devem nortear o direito de família e sucessórios.

Embora náo tenha sido abordado de maneira explícita na lista dos três princípios violados pelo dispositivo citado alhures, outro princípio merece atenção, qual seja, o da igualdade. Com base nele, procura-se alcançar um tratamento legal uniforme e aplicado a todos.

Em seu art. $226, \$ 3^{\circ}$, a $\mathrm{CF} / 1988$ preceitua que se deve facilitar a conversão da uniáo estável em casamento, mas não no sentido de hierarquizar as formas de composição familiar, e sim com o intuito de resguardar a igualdade de tratamento e proporcionar maior segurança jurídica.

O Enunciado n. 3 do IX Congresso Brasileiro de Direito de Família, em Araxá, dispôs que: "em face do princípio da igualdade das entidades familiares, é inconstitucional tratamento discriminatório conferido ao cônjuge e ao companheiro" (BRASIL, 2013), de maneira que, ao se ver configurado um tratamento desigual entre o companheiro e o cônjuge, o princípio da igualdade também se mostra flagrantemente violado.

Foi nesses termos que o relator arrematou pela inconstitucionalidade do art. 1.790 do CC/2002, destacando o tratamento diverso entre os regimes aplicados aos companheiros e aos cônjuges, deduzindo pela aplicação do art. 1829 do CC/2002, com consequente inclusão do companheiro em seu rol, equiparando-o ao cônjuge.

Destaca-se que que os efeitos da decisão foram modulados a fim de não atingir as partilhas feitas judicial e extrajudicialmente, em momento anterior à decisão. Dessa forma, as partilhas judiciais que tivessem transitado em julgado e as extrajudiciais que já constassem de lavratura pública não seriam abarcadas pela decisão do STF, eis, pois, o efeito ex nunc. Assim foi proferido pelo Ministro Barroso:

[...] levando-se em consideração o fato de que as partilhas judiciais e extrajudiciais que versam sobre as referidas sucessōes encontram-se em diferentes estágios de desenvolvimento (muitas já finalizadas sob as regras antigas), entendo ser recomendável 
modular os efeitos da aplicação do entendimento ora firmado. Assim, com o intuito de reduzir a insegurança jurídica, entendo que a solução ora alcançada deve ser aplicada apenas aos processos judiciais em que ainda não tenha havido trânsito em julgado da sentença de partilha, assim como às partilhas extrajudiciais em que ainda não tenha sido lavrada escritura pública (BRASIL, 2017).

A decisão enfrentou o tema da modulação dos efeitos, mas restou incompleta no que tange à definição do companheiro como herdeiro necessário e a regular o direito real de habitação para ele. Ressalta-se que, como houve equiparação do companheiro ao cônjuge, esta deve se estender a essas duas características decorrentes da sucessão. Após a decisão do STF, o Superior Tribunal de Justiça (STJ) pronunciou-se a respeito:

RECURSO ESPECIAL. CIVIL. PROCESSUAL CIVIL. DIREITO DE FAMÍLIA E DAS SUCESSÓES. UNIÃO ESTÁVEL. ART. 1.790 DO CC/2002. INCONSTITUCIONALIDADE. ART. 1.829 DO CC/2002. APLICABILIDADE. VOCAÇÃO HEREDITÁRIA. PARTILHA. COMPANHEIRO. EXCLUSIVIDADE. COLATERAIS. AFASTAMENTO. ARTS. 1.838 E 1.839 DO CC/2002. INCIDÊNCIA. 1. Recurso especial interposto contra acórdão publicado na vigência do Código de Processo Civil de 1973 (Enunciados Administrativos n.s 2 e 3/STJ). 2. No sistema constitucional vigente, é inconstitucional a distinção de regimes sucessórios entre cônjuges e companheiros, devendo ser aplicado em ambos os casos o regime do artigo 1.829 do CC/2002, conforme tese estabelecida pelo Supremo Tribunal Federal em julgamento sob o rito da repercussão geral (Recursos Extraordinários n.s 646.721 e 878.694). 3. $\mathrm{Na}$ falta de descendentes e ascendentes, será deferida a sucessão por inteiro ao cônjuge ou companheiro sobrevivente, ressalvada disposição de última vontade. 4. Os parentes colaterais, tais como irmãos, tios e sobrinhos, são herdeiros de quarta e última classe na ordem de vocação hereditária, herdando apenas na ausência de descendentes, ascendentes e cônjuge ou companheiro, em virtude da ordem legal de vocação hereditária. 5 . Recurso especial não provido (BRASIL, 2018).

Nota-se que o STJ, em atendimento ao entendimento firmado pelo STF, tem proferido decisóes com o mesmo teor, recusando a sucessão dos colaterais, em 
decorrência da inconstitucionalidade do art. 1.790 do CC/2002 e do consequente tratamento equiparado entre cônjuge e companheiro.

Resta evidenciado, então, que, antes da decisão da qual trata este artigo, o companheiro não tinha o direito real de habitação ao imóvel em que constituiu família com o de cujus, o que poderia resultar, conforme Gonçalves (2019, p. 136):

[...] a uma eventual desocupaçấo compulsória do imóvel onde vivia com o finado parceiro, na hipótese de não ter este adquirido bens durante a convivência, ou de tê-lo adquirido só a título gratuito. Nesses casos carece o companheiro do direito à meação e tampouco concorre na herança, que poderá ser atribuída a herdeiros que nem sempre aceitarăo repartir com ele o uso do imóvel residencial.

Cumpre ressaltar, ainda, que a partilha, conforme determinada pelo CC/2002 ao companheiro, torna-o herdeiro de bens dos quais já era meeiro, por haverem sido adquiridos na constância de uniáo estável, submetendo-se, assim, ao regime de comunhão parcial de bens. Posiciona-se categoricamente Ulhôa Coelho (2016, p. 104) quanto à partilha na união estável, nos seguintes termos:

Criando uma odiosa discriminação, os incisos II e III desse dispositivo estabelecem a quota a que tem direito o supérstite, fazendo-a variar de acordo com os demais concorrentes à herança. De início, convém frisar que esse dispositivo não prejudica a meação a que tem direito o companheiro por força do regime legal de bens, na falta de contrato de convivência. Quer dizer, as quotas referidas naquele dispositivo dizem respeito apenas à parte dos bens comuns objeto de sucessão, isto é, à meação titulada pelo convivente falecido $[\ldots]$.

Assim, nota-se que a doutrina não deixou de questionar a injusta partilha disposta no CC/2002, por já entender que ela não merecia vigorar diante do descompasso com os valores sociais brasileiros. Novamente reafirma o doutrinador:

O tratamento discriminatório liberado pelo art. 1.790, II e III, do CC fulmina a constitucionalidade e validade dos preceitos. Por afrontar a Constituição Federal, tanto na garantia do direito de herança $\left(\right.$ art. $\left.5^{\circ}, \mathrm{XXX}\right)$, como na proteção da união estável como entidade familiar (art. 226, $\$ 3^{\circ}$ ), esses dispositivos do Código Civil são inconstitucionais (ULHÔA COELHO, 2016, p. 104). 
Nota-se que, antes do entendimento firmado pelo STF, os Tribunais de Justiça de alguns estados membros decidiram de forma divergente um do outro, gerando contradição e insegurança jurídica por dissídio jurisprudencial. O TJMG e o Tribunal de Justiça de Sáo Paulo (TJSP) entendiam pela constitucionalidade do art. 1.790 do CC/2002, já o Tribunal de Justiça do Rio de Janeiro (TJRJ) sustentava a inconstitucionalidade de tal dispositivo. Neste sentido, destaca um julgado do TJSP:

Agravo de instrumento - Inventário - União estável - Sucessão da companheira - Concorrência à herança com os filhos comuns e exclusivos do falecido - Decisão que determinou a aplicação do art. 1.790, inciso I, do CC - Recurso dos interessados - Alegação de que o dispositivo invocado seria inconstitucional - Descabimento - Constitucionalidade da norma declarada pelo Órgão Especial desta Corte - Vinculação do Órgão fracionário ao entendimento exarado - Inteligência do art. 97 da CF e da Súmula Vinculante n. ${ }^{\circ} 10$ do STF - Filiação híbrida, contudo, cuja sucessão não possui previsão legal - Aplicação, por analogia, do art. 1.790, inciso II, do CC - Precedentes desta Corte e Câmara Decisão reformada apenas para esse fim - AGRAVO PROVIDO EM PARTE (SÃO PAULO, 2016).

Do TJMG, destaca-se o seguinte julgado:

AGRAVO DE INSTRUMENTO - SUCESSÃO - UNIÃO ESTÁVELCOMPANHEIRA - MEEIRA E HERDEIRA - ARTIGO 1790 DO CÓDIGO CIVIL - CONSTITUCIONALIDADE RECONHECIDA. - A constitucionalidade do artigo 1790, III do Código Civil foi reconhecida por este Tribunal de Justiça. - O Código Civil previu duas normas distintas para regular a sucessão: uma, para a hipótese de união estável, a presente no artigo 1.790, e outra para a hipótese de casamento, no artigo 1.829 . Desta forma, não subsiste o argumento do magistrado afirmando que é inconstitucional a distinção de regimes sucessórios entre cônjuges e companheiros. - A agravante, na condiçâao de companheira, deverá figurar como meeira e herdeira, concorrendo na herança, a companheira sobrevivente e os herdeiros sucessíveis, na forma do artigo 1.790, inciso III (MINAS GERAIS, 2017).

O TJRJ, em sentido diverso dos outros dois Tribunais supramencionados, decidiu pela inconstitucionalidade do art. 1.790 do CC/2002, como se depreende do julgado a seguir: 
PROCESSUAL CIVIL E CONSTITUCIONAL. COMPANHEIRO. SUCESSÃO. CONCORRÊNCIA COM PARENTES COLATERAIS SUCESSÍVEIS. INCISO III DO ART. 1790 DO CC. INCONSTITUCIONALIDADE. RECONHECIMENTO PELO ÓRGÃO ESPECIAL. IMPROVIMENTO DO RECURSO. MANUTENÇÃO DA DECISĀO AGRAVADA. Por conceder tratamento desigual à companheira, em relação ao cônjuge, o disposto no art. 1790, III do CC é inconstitucional. A matéria já foi apreciada pelo Órgão Especial desta Tribunal de Justiça, em duas oportunidades, o que dispensa nova Arguição de Inconstitucionalidade. Precedentes do TJERJ. Recurso ao qual se nega provimento (RIO DE JANEIRO, 2014).

Nota-se que, diante da divergência do entendimento entre diferentes Tribunais de Justiça, a decisão do STF surgiu como uma forma de extinguir a controvérsia existente e firmar entendimento que pode ser aplicado a todo território nacional, em exercício de jurisdição sustentável que outorga segurança jurídica a toda a sociedade.

Dessa forma, reflete-se, inclusive tardiamente, a declaração de inconstitucionalidade do STF, já que há muito a doutrina expunha o equívoco do CC/2002 e o desrespeito ao direito de sucessão como direito fundamental e seus decorrentes reflexos na dignidade da pessoa humana e na noção holística de sustentabilidade, além do desenvolvimento sustentável.

\section{Consideraçóes finais}

Conforme exposto nos votos proferidos pelos ministros do STF, uma das principais razóes para a herança é a continuidade do núcleo familiar com a subsistência do companheiro. Resta inviável que o companheiro subsista recebendo, conforme o caso discutido, apenas $1 / 3$ do patrimônio adquirido onerosamente pelo de cujus na constância de sua união estável. Neste ponto, cumpre ressaltar o voto do ministro relator, em que ele expóe as diversas proteçóes exacerbadas dadas à família constituída sob o matrimônio, em que se obstava o divórcio em qualquer situação e havia duras distinçôes entre os filhos tidos dentro dessa estrutura familiar e os que não foram gerados sob a proteção do matrimônio, quando da sucessão de seus pais.

A decisão que garante aos companheiros tratamento idêntico aos cônjuges na sucessão por morte busca valorizar o afeto e a constituição de família que marcam ambas as instituiçóes familiares, de modo a compreender que é preciso valorizar 
não somente as formalidades que implicam a constituição de um casamento, mas também as reais motivaçóes para que aquele núcleo se constitua como tal. Reconhece-se, assim, a família como instrumento de desenvolvimento e promoção da dignidade de seus membros, não somente como instituição a ser protegida, preservada e legalmente regulamentada.

Anteriormente ao CC/2002, leis da década de 1990 (Leis n. 8.971/1994 e 9.278/1996) equiparavam, para efeitos sucessórios, cônjuges e companheiros, concedendo, inclusive, direito de habitação ao supérstite. Não obstante, com o advento do CC/2002, tais leis não mais poderiam vigorar no Direito brasileiro e tiveram sua incidência afastada.

Nota-se, entâo, que, para legisladores e para a sociedade em geral, que é destinatária das leis, não há justificativa para a diferenciação de cônjuge e companheiro. Socialmente, há o popular ditado "juntado com fé, casado é”, de modo a reconhecer o mesmo tratamento público e privado, nos meios sociais, aos “juntados", ou seja, àqueles que estão em uniâo estável, e os que de fato celebraram $\mathrm{o}$ ato solene do casamento civil.

O retrocesso causado pelo $\mathrm{CC} / 2002$ não mais refletia as noçóes sociais do século XXI, representando somente as noções de 1975, à época de sua elaboração, sob o regime militar pautado em extremo conservadorismo.

Não obstante os avanços da decisão em matéria de direito sucessório, há que se ressaltar que, diferente do casamento celebrado civilmente, a união estável deverá ser comprovada em juízo por diversos meios de prova, não bastando somente certidão, conforme ocorre com a comprovaçáo do casamento civil. $\mathrm{O}$ casamento, entáo, deve ser estimulado, para facilitar a outorga uxória e para a concessão de benefício previdenciário, por exemplo.

A equiparação, para efeitos sucessórios, do companheiro ao cônjuge pela decisão do STF está produzindo, sem dúvida, grandes impactos sociais e jurídicos. Ao reconhecer que em ambos os casos as pessoas que se unem para constituir família, baseando-se no afeto que nutrem entre si, o STF reforçou diversos valores sociais que se consolidavam desde a metade do século passado e modernizou o CC/2002, que refletia tấo somente os ideais da época em que foi elaborado, em 1975, sob a forte influência de um regime ditatorial brasileiro em que imperava o conservadorismo e a rejeição às novas formas de união familiar.

Assim, promover-se-á a noção de partilha não se pautando somente nas noçôes jurídicas e formais de família, mas também no afeto que vincula os cidadãos unidos pela força da vontade. Assegura-se à companheira ou companheiro financeiramente dependente do de cujus sua subsistência e, mais ainda, seu direito de permanecer na habitação que dividiam. Ademais, dá-se, de fato, a possibilidade 
de consolidação familiar ainda com o falecimento de um dos membros daquela família, pois restarão protegidos os sobreviventes em matéria financeira.

Portanto, a hipótese inicial foi confirmada, porque o tratamento diferenciado não se mostra consentâneo com os valores da sociedade, não acompanhando a evolução sociocultural.

Acrescenta-se que permanecem os membros de união estável com dificuldades para provar a referida união, visto que não há comprovação mediante mera certidão, como ocorre com o casamento civil, encontrando entraves em sede de direito previdenciário. Em caso de dissolução, ainda em vida, da referida união, há também profundos debates quanto à forma de realização da partilha e também do pagamento de alimentos àquele que náo pode subsistir e que se tornou financeiramente dependente de seu companheiro.

É essencial reforçar, ainda, a relevância da decisão do STF em matéria de efetivação de valores constitucionais, quais sejam, a dignidade da pessoa humana e a sustentabilidade. Ao promover a adequação da norma infraconstitucional, o CC/2002, com a norma constitucional, em seus preceitos de reconhecimento da união estável e direito à herança, o STF reconheceu a importância dos valores sociais no ordenamento jurídico nacional. A identificação social com a sucessão no caso da união estável representou um marco que reafirma a relevância das noçóes sociais no ordenamento jurídico nacional. Muito mais que reforçar a concordância do ordenamento jurídico como sistema inteiro de organização social, o STF corrigiu um equívoco que gerava dissonância entre a evoluçáo dos parâmetros de família e a efetivação legal da partilha de bens.

\section{Referências}

ARAÚJO, A. L. M. et al. Nova perspectiva de fins sucessórios entre cônjuge e companheiro(a): igualdade de direitos e a modulação de efeitos. Revista Científica da Academia Brasileira de Direito Civil, Juiz de Fora, v. 3, n. 2, p. 1-16, 2018. Disponível em: <https://abdc.emnuvens.com.br/abdc/article/view/21/17> . Acesso em: 25 ago. 2019.

ASSOCIAÇÃO DOS REGISTRADORES DE PESSOAS NATURAIS DO ESTADO DE SÃO PAULO. Uniôes consensuais superam casamento civil e religioso. Jus Brasil, São Paulo, 2014. Disponível em: <https://arpen-sp.jusbrasil. com.br/noticias/127239479/unioes-consensuais-superam-casamento-civil-ereligioso >. Acesso em: 13 mar. 2019.

BRASIL. Presidência da República. Casa Civil. Subchefia para Assuntos Jurídicos. 
Constituição da República Federativa do Brasil. Brasília, DF: 1988. Disponível em: $<$ http://www.planalto.gov.br/ccivil_03/constituicao/constituicao.htm>. Acesso em: 24 abr. 2018.

BRASIL. Decreto-lei n. 7.036, de 10 novembro de 1944. Reforma da Lei de Acidentes de Trabalho. Diário Oficial da União, Brasília, 31 dez. 1944. Disponível em: <http://www.planalto.gov.br/ccivil_03/decreto-lei/1937-1946/Del7036.htm>. Acesso em: 5 dez. 2016.

BRASIL. Enunciado n. 13. Jornada de Direito de Família. Corregedoria Geral de Justiça do TJBA, Salvador, 2011.

BRASIL. Enunciado n. 117. Jornada de Direito Civil. Conselho da Justiça Federal, Brasília, 2013. Disponível em: <https://www.cjf.jus.br/cjf/corregedoriada-justica-federal/centro-de-estudos-judiciarios-1/publicacoes-1/jornadas-cej/ EnunciadosAprovados-Jornadas-1345.pdf>. Acesso em: 22 ago. 2019.

BRASIL. Lei n. 3.071, de 01 de janeiro de 1916. Código Civil dos Estados Unidos do Brasil. Diário Oficial da União, Brasília, 05 jan. 1916. Disponível em: <https:// www.planalto.gov.br/ccivil_03/leis/L3071.htm>. Acesso em: 5 dez. 2016.

BRASIL. Lei n. 4.297, de 23 de dezembro de 1963. Dispóe sobre a aposentadoria e pensôes de Institutos ou Caixas de Aposentadoria e Pensôes para Ex-Combatentes e seus dependentes. Diário Oficial da União, Brasília, 14 jan. 1964. Disponível em: <https://www.planalto.gov.br/ccivil_03/leis/1950-1969/L4297.htm>. Acesso em: 5 dez. 2016.

BRASIL. Lei n. 6.515, de 26 de dezembro de 1977. Regula os casos de dissolução da sociedade conjugal e do casamento, seus efeitos e respectivos processos, e dá outras providências. Diário Oficial da União, Brasília, 27 dez. 1977. Disponível em: <https://www.planalto.gov.br/ccivil_03/leis/L6515.htm>. Acesso em: 14 dez. 2016 .

BRASIL. Lei n. 8.971, de 29 de dezembro de 1994. Regula o direito dos companheiros a alimentos e à sucessão. Diário Oficial da União, Brasília, $30 \mathrm{dez}$. 1994. Disponível em: <http://www.planalto.gov.br/ccivil_03/LEIS/L8971.htm>. Acesso em: 23 ago. 2019.

BRASIL. Lei n. 9.278, de 10 de maio de 1996. Regula o $\$ 3^{\circ}$ do art. 226 da Constituição Federal. Diário Oficial da União, Brasília, 13 maio 1996. Disponível em: <http://www.planalto.gov.br/ccivil_03/LEIS/L9278.htm>. Acesso em: 23 ago. 2019. 
BRASIL. Lei n. 10.406, de 10 de janeiro de 2002. Institui o Código Civil. Diário Oficial da União, Brasília, 11 jan. 2002. Disponível em: <http://www.planalto. gov.br/ccivil_03/leis/2002/L10406.htm>. Acesso em: 5 dez. 2016.

BRASIL. Superior Tribunal de Justiça, Recurso Especial n. 1357117/ MG. Ementa: RECURSO ESPECIAL. CIVIL. PROCESSUAL CIVIL. DIREITO DE FAMÍLIA E DAS SUCESSÔES. UNIÃO ESTÁVEL. ART. 1.790 DO CC/2002. INCONSTITUCIONALIDADE. ART. 1.829 DO CC/2002. APLICABILIDADE. VOCAÇÃO HEREDITÁRIA. PARTILHA. COMPANHEIRO. EXCLUSIVIDADE. COLATERAIS. AFASTAMENTO. ARTS. 1.838 E 1.839 DO CC/2002. INCIDÊNCIA. 1. Recurso especial interposto contra acórdáo publicado na vigência do Código de Processo Civil de 1973 (Enunciados Administrativos n.s 2 e 3/STJ). 2. No sistema constitucional vigente, é inconstitucional a distinção de regimes sucessórios entre cônjuges e companheiros, devendo ser aplicado em ambos os casos o regime do artigo 1.829 do CC/2002, conforme tese estabelecida pelo Supremo Tribunal Federal em julgamento sob o rito da repercussão geral (Recursos Extraordinários n.s 646.721 e 878.694). 3. Na falta de descendentes e ascendentes, será deferida a sucessão por inteiro ao cônjuge ou companheiro sobrevivente, ressalvada disposição de última vontade. 4. Os parentes colaterais, tais como irmãos, tios e sobrinhos, são herdeiros de quarta e última classe na ordem de vocação hereditária, herdando apenas na ausência de descendentes, ascendentes e cônjuge ou companheiro, em virtude da ordem legal de vocação hereditária. 5 . Recurso especial não provido. Relator: Ministro Ricardo Villas Bôas Cueva, Terceira Turma. Data de Julgamento: 13 mar. 2018. Diário de Justiça Eletrônico, Brasília, 26 mar. 2018.

BRASIL. Supremo Tribunal Federal. Plenário. Recurso Extraordinário n. 878.694/MG. EMENTA: DIREITO DAS SUCESSÓES. RECURSO EXTRAORDINÁRIO. DISPOSITIVOS DO CÓDIGO CIVIL QUE PREVEEM DIREITOS DISTINTOS AO CÔNJUGE E AO COMPANHEIRO. ATRIBUIÇÃO DE REPERCUSSÃO GERAL. 1. Possui caráter constitucional a controvérsia acerca da validade do art. 1.790 do Código Civil, que prevê ao companheiro direitos sucessórios distintos daqueles outorgados ao cônjuge pelo art. 1.829 do mesmo Código. 2. Questáo de relevância social e jurídica que ultrapassa os interesses subjetivos da causa. 3. Repercussão geral reconhecida. Rel. Min. Luís Roberto Barroso, Brasília, 16 abr. 2017. Diário de Justiça Eletrônico, Brasília, 19 maio 2017. Disponível em: <http://stf.jusbrasil.com. br/jurisprudencia/31 1628824/repercussao-geral-no-recurso-extraordinariorg-re-878694-mg-minas-gerais-1037481-7220098130439/inteiro-teor311628833?ref=juris-tabs>. Acesso em: 26 ago. 2019. 
BRASIL. Supremo Tribunal Federal. Repercussão Geral no Recurso Extraordinário n. 878.694/MG. Diário de Justiça Eletrônico, Brasília. 16 abr. 2015. Disponível em: <http://stf.jusbrasil.com.br/jurisprudencia/311628824/ repercussao-geral-no-recurso-extraordinario-rg-re-878694-mg-minasgerais-1037481-7220098130439/inteiro-teor-311628833?ref=juris-tabs>. Acesso em: 12 dez. 2016.

BRASIL. Supremo Tribunal Federal. Súmula n. 35, de 13 dez. 1963. Em caso de acidente do trabalho ou de transporte, a concubina tem direito de ser indenizada pela morte do amásio, se entre êles não havia impedimento para o matrimônio. Diário de Justiça Eletrônico, Brasília, 13 dez. 1963. Disponível em: <http://sislex. previdencia.gov.br/paginas/75/STF/35.htm>. Acesso em: 5 dez. 2016.

BRASIL. Supremo Tribunal Federal. Súmula n. 380, de 03 abr. 1964. Comprovada a existência de sociedade de fato entre os concubinos, é cabível a sua dissolução judicial, com a partilha do patrimônio adquirido pelo esforço comum. Diário de Justiça Eletrônico, Brasília, 8 maio 1964. Disponível em: <http://www.stf.jus.br/ portal/jurisprudencia/listarJurisprudencia.asp?s1=380.NUME. $\% 20 \mathrm{NAO} \% 20 \mathrm{~S}$. FLSV.\&base=baseSumulas>. Acesso em: 5 dez. 2016.

COElHO, S. O. P.; MELlO, R. A. C. A sustentabilidade como um direito fundamental: a concretização da dignidade da pessoa humana e a necessidade de interdisciplinaridade do direito. Revista Veredas do Direito, Belo Horizonte, v. 8, n. 15, p. 9-24, jan./jun. 2011. Disponível em: <http://www.domhelder.edu.br/ revista/index.php/veredas/article/view/208>. Acesso em: 8 mar. 2019.

FREITAS, J. Sustentabilidade. 3. ed. Belo Horizonte: Fórum, 2016.

GAGLIANO, P. S.; PAMPLONA FILHO, R. Novo curso de direito civil: direito de família. 6. ed. rev. e atual. São Paulo: Saraiva, 2016.

GOMES, M. F.; FERREIRA, L. J. A dimensão jurídico-política da sustentabilidade e o direito fundamental à razoável duração do procedimento. Revista do Direito, Santa Cruz do Sul, n. 52, v. 2, p. 93-111, maio/set. 2017. Disponível em: <http:// dx.doi.org/10.17058/rdunisc.v2i52.8864>. Acesso em: 7 mar. 2019.

GOMES, M. F.; OLIVEIRA, I. G. S. Inteligência artificial e execuções penais sustentáveis: uma defesa aos direitos humanos dos presos. In: SOBRINHO, Liton Lanes Pilau (Org.). Desafios da sustentabilidade na era tecnológica: a proteção dos direitos humanos. Passo Fundo: Habitus Editora, 2018. Cap. 13, p. 212-228. Disponível em: <https://www.academia.edu/37815284/ INTELIG\%C3\%8ANCIA_ARTIFICIAL_E_EXECU\%C3\%87\%C3\%95ES_ 
PENAIS_SUSTENT\%C3\%81VEIS_UMA_DEFESA_AOS_DIREITOS_ HUMANOS_DOS_PRESOS>. Acesso em: 25 ago. 2019.

GONÇALVES, C. R. Direito civil brasileiro: direito das sucessões. 3. ed. São Paulo: Saraiva, 2019. v. 7.

HIRONAKA, G. M. F. N.; PEREIRA, R. C. Direito das sucessóes. 2. ed. Belo Horizonte: Del Rey, 2007.

LUCA, P. P. A inconstitucionalidade do artigo 1.790 do Código Civil e a proteção do companheiro. 2018. 73f. Monografia (Graduação em Direito) - Universidade Federal do Rio de Janeiro, Rio de Janeiro. Disponível em: <https://pantheon.ufrj. br/bitstream/11422/6008/1/PPLuca.pdf>. Acesso em: 24 ago. 2019.

MINAS GERAIS. Tribunal de Justiça de Minas Gerais. Apelação Cível n. 1.0439.09.103748-1/001. Ementa: RECONHECIMENTO DE UNIÃO ESTÁVEL. PARTILHA. DIREITOS SUCESSÓRIOS DA COMPANHEIRA. ARTIGO 1.790, III, DO CÓDIGO CIVIL. CONSTITUCIONALIDADE. RECONHECIMENTO PELO ÓRGÃO ESPECIAL DESTE TRIBUNAL DE JUSTIÇA, DO DIREITO DE A COMPANHEIRA SOBREVIVENTE HERDAR TÁO SOMENTE OS BENS ADQUIRIDOS ONEROSAMENTE DURANTE A UNIÃO ESTÁVEL, EM CONCORRÊNCIA COM OS PARENTES COLATERAIS DE SEGUNDO GRAU, EXCLUÍDOS, PORTANTO, OS BENS PARTICULARES. RECURSO CONHECIDO E PROVIDO. Rel. Des. Bitencourt Marcondes, 8a Câmara Cível. Belo Horizonte, 09 jun. 2011. Diário de Justiça Eletrônico, Belo Horizonte, 31 ago. 2011. Disponível: <http:// www5.tjmg.jus.br/jurisprudencia/pesquisaPalavrasEspelhoAcordao.do?\&numeroRegistro $=3 \&$ totalLinhas $=3 \&$ paginaNumero $=3 \&$ linhasPorPagina $=1 \&$ pala vras=APELA $\%$ C7\%C3O $\% 20 \mathrm{C} \%$ CDVEL. $\% 20$ RECONHECIMENTO $\% 20$ UNI\%C3O\%20EST\%C1VEL.\%20PARTILHA.\%20DIREITOS\%20SUCESS\%D3RIOS\%20COMPANHEIRA.\&pesquisarPor=ementa\&pesquisaTesauro $=$ true $\&$ orderByData $=1 \&$ referenciaLegislativa $=$ Clique $\% 20$ na $\% 20$ lupa $\% 20$ para $\% 20$ pesquisar $\% 20$ as $\% 20$ refer $\%$ EAncias $\% 20$ cadastradas...\&pesquisaPalavras=Pesquisar\&>. Acesso em: 13 dez. 2016.

RIO DE JANEIRO. Tribunal de Justiça do Rio de Janeiro, - Agravo de Instrumento n. 0051766-05.2014.8.19.0000. Ementa: PROCESSUAL CIVIL E CONSTITUCIONAL. COMPANHEIRO. SUCESSÃO. CONCORRÊNCIA COM PARENTES COLATERAIS SUCESSÍVEIS. INCISO III DO ART. 1790 DO CC. INCONSTITUCIONALIDADE. RECONHECIMENTO PELO ÓRGÃO ESPECIAL. IMPROVIMENTO DO RECURSO. MANUTENÇÃO 
DA DECISÃO AGRAVADA. Por conceder tratamento desigual à companheira, em relação ao cônjuge, o disposto no art. 1790, III do CC é inconstitucional. A matéria já foi apreciada pelo Órgão Especial desta Tribunal de Justiça, em duas oportunidades, o que dispensa nova Arguição de Inconstitucionalidade. Precedentes do TJERJ. Recurso ao qual se nega provimento. Relator(a) Des(a). Marco Antonio Ibrahim, 4a Câmara Cível. Data de Julgamento: 22 out. 2014. Diário de Justiça Eletrônico, Rio de Janeiro, 30 out. 2014.

SÃO PAULO. Tribunal de Justiça de São Paulo - Agravo de Instrumento 2150854-50.2015.8.26.0000. Ementa: Agravo de instrumento - Inventário União estável - Sucessão da companheira - Concorrência à herança com os filhos comuns e exclusivos do falecido - Decisão que determinou a aplicação do art. 1.790, inciso I, do CC - Recurso dos interessados - Alegação de que o dispositivo invocado seria inconstitucional - Descabimento - Constitucionalidade da norma declarada pelo Órgáo Especial desta Corte - Vinculação do Órgáo fracionário ao entendimento exarado - Inteligência do art. 97 da CF e da Súmula Vinculante n. 10 do STF - Filiação híbrida, contudo, cuja sucessão não possui previsão legal Aplicação, por analogia, do art. 1.790, inciso II, do CC - Precedentes desta Corte e Câmara - Decisão reformada apenas para esse fim - AGRAVO PROVIDO EM PARTE. Relator (a): Miguel Brandi; Órgáo Julgador: 7a Câmara de Direito Privado; Foro de Franca - 2a Vara de Família e Sucessóes. Data de Julgamento: 16 mar. 2016. Diário de Justiça Eletrônico, São Paulo, 30 mar. 2016.

STAFFEN, M. R.; SANTOS, R. P. O fundamento cultural da dignidade da pessoa humana e sua convergência para o paradigma da sustentabilidade. Revista Veredas do Direito, Belo Horizonte, 凶v. 13, \ n. 26, p. 263-288, maio/ago. 2016. Disponível em: <http://dx.doi.org/10.18623/rvd.v13i26.814>. Acesso em: 8 mar. 2019.

ULHÔA COELHO, F. Curso de direito civil: família - sucessōes. 8. ed. São Paulo: Saraiva, 2016. v. 5. 


\title{
A AUTORREGULAÇÃO DOS RISCOS DAS NOVAS TECNOLOGIAS NỎ ÂMBITO INTERNACIONAL: UM ESTUDO A PARTIR DA ISO/TC 229'
}

\author{
Universidade Comunitária da Regiāo de Chapecó (UNOCHAPECÓ) \\ Jaqueline Kelli Percio ${ }^{3}$ \\ Universidade Comunitária da Região de Chapecó (UNOCHAPECÓ)
}

Universidade do Estado de Santa Catarina (UDESC)

Artigo recebido em: 16/09/2019.

Artigo aceito em: 01/10/2019.

\section{Resumo}

A partir da hipótese de que os Estados apresentam dificuldades para a governança dos riscos socioambientais das novas tecnologias, em função de fatores como os limites geográficos, a perda do poder normativo e a tensão entre os sistemas jurídicos estatais e transnormativos, este artigo analisa a possibilidade de regulação internacional das novas tecnologias a partir do conjunto de normas regulamentares desenvolvidas pelo ISO/TC 229, que estabelece padrôes técnicos para a nanotecnologia. $O$ estudo justifica-se na medida em que, ao contrário da regulamentaçáo estatal, cuja aplicabilidade depende invariavelmente de critérios de soberania, os critérios de autorregulação têm possibilidade de serem observados por agentes econômicos, sediados nos mais distintos países. O trabalho trata, inicialmente, dos desafios que a nanotecnologia impóe para a governança de riscos socioambientais. Posteriormente, aborda a autorregulação como elemento transnormativo de regulaçáo das novas tecnologias e, por fim, a partir da análise das normas do ISO/TC 229, verifica, em exercício de indução, a adequação da autorregulamentação como mecanismo de imposição de padrôes para as novas tecnologias.

Palavras-chave: autorregulamentação; globalização; governança; nanotecnologia; riscos das novas tecnologias.

1 Pesquisa financiada pela CAPES.

2 Doutor em Direito pela Universidade Federal de Santa Catarina (UFSC). Professor do Programa de Pós-Graduação Stricto Sensu em Direito na UNOCHAPECÓ. Líder do Grupo de Pesquisa Direito, Democracia e Participação Cidadã da UNOCHAPECÓ. Membro da Rede de Pesquisa Nanotecnologia, Sociedade e Ambiente (RENANOSOMA). ORCID: https://orcid.org/0000-0003-2333-0232 / e-mail: rpereira@unochapeco.edu.br 3 Mestranda em Direito pela UNOCHAPECÓ. Bolsista pela CAPES/PROSUP. Pesquisadora do Grupo de Pesquisa Direito, Democracia e Participação Cidadã certificado pela UNOCHAPECÓ. E-mail: percio@unochapeco.edu.br

4 Engenheiro Mecânico pela Universidade do Estado de Santa Catarina (UDESC). E-mail: sacomori01@gmail. com 


\section{SELF-REGULATION OF THE RISKS OF NEW TECHNOLOGIES AT INTERNATIONAL LEVEL: A STUDY FROM ISO/TC 229}

\section{Abstract}

On the assumption that States have in the most different countries. The difficulties in the governance of the social and environmental risks of new technologies, depending on factors such as geographical limits, the loss of normative power and the tension between state and transnormative legal systems, this work analyzes the possibility of international regulation of new technologies based on a set of regulatory standards developed by ISO/TC 229, which establishes technical standards for nanotechnology. This study is justified to the extent that, contrary to state regulation, whose applicability invariably depends on sovereignty criteria, self-regulation criteria are possible to be observed by economical agents, settled work deals initially with the challenges imposed by nanotechnology to the governance of social and environmental risks. Afterwards, it approaches selfregulation as a transnormative element to the regulation of new technologies and, finally, from the analysis of ISO/TC 229 standards, it verifies, by induction, the suitability of self-regulation as a mechanism of setting standards for new technologies.

Keywords: globalization; governance; nanotechnology; risks of the new technologies; self-regulation.

\section{Introduçáo}

O caráter disruptivo de algumas tecnologias impóe alteraçôes de diversas naturezas à sociedade e pressiona o sistema jurídico a elaborar respostas ao adequado tratamento de suas novidades.

A resposta do Direito, tomado como instrumento de atuação e de soberania do Estado, nas mais das vezes, peca pela inadequação operacional e temporal aos novos riscos e desafios impostos por essas novas tecnologias. Há aí, três problemas evidentes.

Um relacionado ao campo da linguagem: o Direito opera a partir de pressupostos de decisão nem sempre moldáveis à novidade, principal característica de uma tecnologia que, em muito pouco tempo, torna sem sentido social outras que a antecederam.

Um segundo, de cunho temporal: o Direito tem dificuldade de acompanhar a velocidade das mudanças que as rupturas tecnológicas causam na sociedade. 
Um terceiro, ligado ao espaço geográfico sobre o qual o Estado exerce seu poder regulatório, nem sempre equivalente ao território mercantil e de riscos das novas manufaturas, formas de gerar energia etc.

Tais problemas, além de demonstrar a perda da centralidade e do poder normativo do Estado mediante a emergência de sujeitos de grande envergadura, principalmente econômica, que atuam em âmbito global, indicam a necessidade da adoção de outros mecanismos de governança mais dúcteis e adaptáveis a cenários de grandes mudanças.

A consolidação de um mercado global que, com base no atual estágio da globalização, opera a partir da atuação dos grandes blocos econômicos e, por outro lado, revela ainda mais as dificuldades para que os Estados implementem sistemas de governança dos riscos socioambientais das novas tecnologias.

Ao mesmo tempo que indicam as limitaçôes dos Estados, tais fatores possibilitam o surgimento de novos mecanismos de governança, muitos dos quais produzidos por grupos de interesses ou por organizaçóes internacionais de cunho privado, dotadas de legitimidade para propor padróes de qualidade e segurança, por meio da normalizaçāo. ${ }^{5}$

A normalização é uma das atividades da autorregulação. Por não ser dotada de legitimidade política, ela se fundamenta na ciência e na tecnologia para o estabelecimento de padróes técnicos, materializados por meio de normas.

As normas fornecem standards, que são regras, diretrizes ou características a serem voluntariamente observadas por um grupo de entidades envolvidas em determinada cadeia produtiva.

Apesar de não serem vinculantes, as normas quase sempre expressam o consenso sobre o estado da arte de determinado assunto, obtido entre especialistas das partes interessadas (ABNT, 2019).

Em que pese a importância dos debates entre as vantagens e desvantagens sobre a autorregulação e a normalização, este artigo analisa a iniciativa mais bem-sucedida, em nível mundial, no estabelecimento de padrōes mínimos para os diversos setores econômicos que se utilizam da nanotecnologia para a fabricação de produtos de diversas naturezas.

O Comitê Técnico ISO/TC 229 congrega o conjunto de normas técnicas mais avançadas na área da nanotecnologia. Apesar de não serem cogentes, na atualidade, as Normas ISO/TC 229 são as que apresentam maiores possibilidades

5 Segundo a Associação Brasileira de Normas Técnicas (ABNT, 2019), a “[...] normalização é o processo de formulação e aplicação de regras para a solução ou prevenção de problemas, com a cooperação de todos os interessados, e, em particular, para a promoção da economia global. No estabelecimento dessas regras recorre-se à tecnologia como o instrumento para estabelecer, de forma objetiva e neutra, as condições que possibilitem que o produto, projeto, processo, sistema, pessoa, bem ou serviço atendam às finalidades a que se destinam, sem se esquecer dos aspectos de segurança". 
de estabelecer padróes de segurança contra os riscos da nanotecnologia, dada a ausência de normativas estatais nanoespecíficas em praticamente todos os países. Daí a importância de serem analisadas.

Os objetivos do presente artigo vão além da verificação das Normas ISO $\mathrm{TC} / 229$. Elas são tomadas como um caso a partir do qual se analisa o papel da autorregulação na construção de uma governança multinível para a construção de níveis adequados de proteção aos direitos humanos e à higidez do meio ambiente em sociedades pautadas em contínuos e infindáveis incrementos tecnológicos.

Para tanto, inicia-se o estudo pelos desafios que essa tecnologia impóe à regulamentação estatal.

\section{Desafios da nanotecnologia à regulamentaçáo estatal}

Serão tratadas, neste espaço, as características da nanotecnologia que tornam sua regulamentaçáo dificultosa pelos Estados.

A nanotecnologia é uma tecnologia disruptiva, por pertencer ao conjunto de tecnologias que rompem abruptamente com o paradigma tecnológico anterior ao, imporem novos padróes que tornarão obsoletos e sem sentido social aqueles que dominavam o mercado até então.

Esse caráter advém da possibilidade que confere à manipulação da matéria em dimensão extremamente diminuta.

Nanotecnologia é comumente definida como uma tecnologia que permite a manipulação da matéria em nível nanométrico e a fabricação de materiais a partir de um tamanho extremamente reduzido da matéria, entre 1 e 100 nanômetros. O prefixo nano - anão, em grego - refere-se ao nanômetro $(\mathrm{nm})$, que equivale a 0,000001 $\left(10^{-6}\right)$ milímetros e a 0,000000001 $\left(10^{-9}\right)$ metros, ou seja: um nanômetro é igual um milionésimo de milímetro ou a um bilionésimo de metro.

Com a utilização da nanotecnologia é possível, por exemplo, construir nanotubos de carbono, que são materiais nanoengenheirados, com diâmetro que gira em torno de 1 nanômetro. Os nanotubos de carbono apresentam as seguintes características mais marcantes: alta resistência mecânica, flexibilidade em torno de seu eixo e alta eficiência condutora (FRAGOSO, 2010).

Com relação à elasticidade, o nanotubo de carbono conta com um módulo de Yong $(\mathrm{Y})$ - parâmetro mecânico relativo à rigidez de determinado material - de, aproximadamente, $4 \times 10^{12} \mathrm{~N} / \mathrm{m}^{2}$. Só para se ter uma ideia, o diamante apresenta um módulo de Yong (Y) igual a $1,25 \times 10^{12} \mathrm{~N} / \mathrm{m}^{2}$, o ferro, de $0,21 \times 10^{12} \mathrm{~N} / \mathrm{m}^{2}$, e o aço, de $0,2 \times 10^{12} \mathrm{~N} / \mathrm{m}^{2}$. A resistência à ruptura de um nanotubo de carbono, quando submetido a tensão, é de $22 \times 10^{9} \mathrm{~N} / \mathrm{m}^{2}, 100$ vezes maior que a do aço 
$\left(44 \times 10^{7} \mathrm{~N} / \mathrm{m}^{2}\right)$. Tais características fazem que o nanotubo se comporte como um canudo elástico, pois, quando a força externa é removida, os defeitos induzidos pela força reorganizam-se e o tubo volta a sua estrutura original (FRAGOSO, 2010).

Os nanotubos de carbono são dotados de alta condutividade térmica, duas vezes maior que a do diamante (condutividade térmica do diamante $=3.320$ $\mathrm{W} / \mathrm{m} . \mathrm{K}$; condutividade térmica do nanotubo de carbono $=6.600 \mathrm{~W} / \mathrm{m} . \mathrm{K}$ ) e suportam bem a corrente elétrica, podendo atuar com característica metálica, semicondutora e até supercondutora (FRAGOSO, 2010; ARCURI; PINTO, 2010).

Por apresentarem propriedades diversas, que dependem de sua estrutura e tamanho, apresentando comportamento metálico, semicondutor ou supercondutor, em função da combinação dos índices que os definem, os nanotubos de carbono acabam tendo grande utilidade para muitas aplicaçôes, como sensores ou dispositivos de controle eletrônico. O desempenho mecânico, representado por altos índices de flexibilidade e elasticidade, torna os nanotubos de carbono próprios para atuar como compósitos de materiais (TROCHE, 2007).

As mesmas características que fazem que os nanotubos de carbono possam ser utilizados, com a mesma eficiência, desde a manufatura de smartphones até a fabricação de para-choques de veículos, fazem deles um fator de alto risco para a saúde daqueles que o manipulam. $\mathrm{O}$ tamanho nanométrico, associado à resistência e à baixa volatilidade química, faz que os nanotubos de carbono cheguem com facilidade aos pulmôes dos trabalhadores, se instalem nas células pulmonares e iniciem processos de inflamação crônica.

O exemplo dos nanotubos de carbono permite inferir que a nanotecnologia gera uma série de ruídos no sistema jurídico, o qual deverá arquitetar cenários de governança capazes de aliar interesses muitas vezes colidentes.

Por ser uma tecnologia recente e baseada na manipulação da matéria em uma escala regida pela física quântica, pouco se sabe sobre seus efeitos, pois não é possível, com base no conhecimento acumulado sobre o comportamento dos materiais em escala macro, determinar como uma nanopartícula do mesmo material se comportará.

Em outros termos, manipular a matéria no nível nanométrico é lidar com o risco.

Fragoso (2010) aponta como as principais causas de riscos relacionadas à nanotecnologia: (i) a incerteza quanto à validade de avaliaçóes de risco desenvolvidas sobre a base da química tradicional, dada a dependência do comportamento dos nanomateriais à estrutura física e química que apresentam; (ii) 
a ausência de conhecimento sobre as respostas dos pulmóes à inalação de partículas insolúveis nanoengenheiradas; (iii) a falta de informaçóes disponíveis sobre o comportamento de materiais nanoestruturados no corpo; (iv) a possibilidade de as partículas nanométricas poderem ser removidas dos pulmôes por vias não convencionais e afetar outras partes do corpo, incluindo o sistema cardiovascular, fígado, rins e cérebro, em funçáo do pouco conhecimento sobre os impactos de nano-objetos sobre esses órgãos; (v) a carência de estudos sobre a capacidade de as nanopartículas penetrarem a pele - o efeito potencial da utilização de partículas nanoestruturadas em cosméticos e produtos de pele pode não ser prejudicial, mas isso requer um estudo mais aprofundado; (vi) o parco conhecimento sobre os riscos da ingestáo, via aditivos alimentares ou por acidente, de nano-objetos; e (vii) a ausência de estudos mais aprofundados acerca dos impactos da liberação de nanomateriais estruturados e dos nano-objetos sobre o meio ambiente.

A inaptidão do Direito tradicional em lidar com a governança do risco é patente. A maioria dos países não tem estrutura jurídica e institucional para aplicar o princípio da precauçáo de maneira eficaz.

Partindo-se de um critério fraco, a precaução atuaria somente em situaçóes nas quais danos sérios e irreversíveis fossem iminentes. A aplicação forte da precauçáo somente poderia ser imaginada em um cenário de exceção da norma vigente, pois, em nome de eventuais danos futuros, paralisar-se-iam atividades de vital importância para a economia dos países.

Logo se vê que a aplicação da precaução de modo adequado depende de um juízo de ponderação ligado à resolução de casos concretos.

A aplicação da precaução no âmbito de políticas públicas, apesar de esta ser reiteradamente afirmada como princípio, é, via de regra, dependente de sistemas de control banding, mais adequados à governança ou mesmo à gestáo de riscos de atividades a partir de um nível mínimo de conhecimento quanto ao potencial grau de lesividade dos materiais e processos nelas envolvidos.

Em atividades envolvendo a nanotecnologia, a propriedade equivalente entre materiais de diversas escalas não é, necessariamente, uma medida adequada ao estabelecimento de políticas de governança estatais de precauçáo, posto que as características físico-químicas das nanopartículas não equivalem às apresentadas pelo mesmo material em escala macro.

A grande dificuldade em atualizar o estado da arte dos riscos da nanotecnologia faz que a atividade reguladora do Estado dependa cada vez mais de sistemas de peritos e de parâmetros técnicos e científicos, o que acaba esvaziando o Direito - a manifestação, por excelência, da soberania dos Estados.

Acrescendo-se a esse cenário o caráter global dos principais agentes econômicos, 
que detêm interesses óbvios sobre a nanotecnologia, e a não delimitação geográfica de seus riscos, verifica-se que a autorregulação tem potencialidades de estabelecer, com maior facilidade, padrôes técnicos aplicáveis à governança dos riscos da nanotecnologia, que atuam como elementos transnormativos de regulação das novas tecnologias.

\section{A autorregulação como elemento transnormativo de regulação das novas tecnologias}

O Estado ${ }^{6}$ muda suas bases constantemente. Tal fato pode ser observado pelo passar do Estado absolutista, liberal, social-democrático ou de bem-estar, neoliberal, até ser atingido pelo fenômeno da globalização.

Por sua vez, a globalização ${ }^{7}$ pode ser entendida como um processo provocado pela quebra de barreiras físico-temporais, impulsionando a modernização e reformulando as relaçôes sociais, econômicas e jurídicas (BARBOSA, 2017).

No direito interno a lei se póe em lugar privilegiado na estrutura do Estado. Isso porque, conforme Canotilho (1999, p. 64), a lei é "expressão da vontade comunitária veiculada através de órgãos representativos dotados de legitimação democrática direta".

A democracia é um processo em constante construção, as experiências entre seres livres e iguais vão se renovando. Essa é a justificativa para se construir uma ferramenta plausível para corrigir as patologias e prosseguir com o projeto da modernidade, sempre levando em conta as exigências do próprio desenvolvimento e do contexto histórico (ALVES, 2014, p. 191-192).

No âmbito global, o cenário atual remete à chamada transnacionalidade,

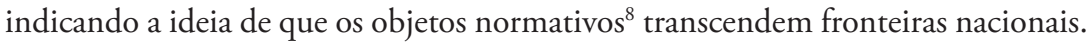
$\mathrm{O}$ Estado-nação passa a concorrer com novos atores não organizados dentro do modelo político de poder soberano estatal, reivindicando legitimidade e traçando uma forte busca por reconhecimento de seus atos e regras como jurídicas (BARBOSA, 2017).

6 Para Cicco e Gonzaga (2008, p. 43), o Estado é "uma instituição organizada política, social e juridicamente, ocupa um território definido e, na maioria das vezes, sua lei maior é uma Constituição escrita. É dirigido por um governo soberano reconhecido interna e externamente, sendo responsável pela organização e pelo controle social, pois detém o monopólio legítimo do uso da força e da coerção".

7 globalização, para Bauman (2008, p. 48), “[...] indica os processos vistos como autopropagáveis, espontâneos e erráticos, sem ninguém sentado à mesa de controle ou planejando, muito menos se encarregando de resultados finais. Podemos dizer, sem muito exagero, que o termo "globalização" se refere à natureza desordenada dos processos que ocorrem acima do território "principalmente coordenado" e administrado pelo "mais alto nível" do poder institucionalizado, isto é, Estados soberanos."

8 Para Barbosa (2017, p. 21-22), "[...] tais atores criam uma comunidade transnacional extra-estatal e produzem uma série de atos, documentos, resoluções, contratos, dentre outros, hoje denominados de objetos normativos". 
Nistler (2018, p. 319) destaca que o transnacionalismo tem duas características fortes, sendo elas a desterritorialidade, sinalizando o desaparecimento das fronteiras, e o enfraquecimento do Estado soberano, pois se vê o ruir de suas bases. Afirma que "[...] o transnacionalismo tem alterado significativamente as características bases do Estado, dando a ele novo formato e, portanto, novo modelo em suas concepçôes, a citar, em especial, a soberania, antes definida, e o território, antes delimitado".

A dinamização dessa interação normativa, caracterizadora de uma relação envolta em uma sociedade transnacional, que propicia um sistema de interação jurídica entre o internacional global - e o local, acaba produzindo o que se pode chamar de uma relação transnormativa entre Direito Internacional e Direito Interno (MENEZES, 2007, p. 140).

Para Menezes (2007), não se trata do afastamento do caráter de internacionalidade das relaçóes entre Estados, especialmente no aspecto da produção normativa, mas que a transnormatividade ocorre dentro do mesmo espaço, interferindo e mudando a relação do Direito Internacional com o Direito Interno.

Parte-se, então, do pressuposto de que a governança é realizada não mais somente pelos Estados soberanos, mas também pelos atores. Para Lima (2014), a governança global "É a composição que inclui sistemas de regras nacionais, internacionais e transnacionais em diferentes níveis de atividade humana, que foram se constituindo para conduzir a cooperação global em face dos objetivos comuns".

Disso surge como consequência um segundo elemento: o fato da governança não derivar apenas de mecanismos regulatórios e prescritos, ela é alcançada se o sistema de ordenação for aceito pela maioria. Ou seja, se o governo funciona por meio de seus elementos regulatórios formais e prescritos, mesmo em face de ampla oposição política, a governança não opera nessas mesmas condiçōes e, portanto, o aceite do sistema de ordenação por parte da maioria é determinante para a sua existência (PEREIRA; RAMOS; SANTOS FILHO, p. 17).

Nesse contexto, Caletti e Staffen (2019, p. 288) afirmam que o Direito, enquanto gênero, está dividido em Direito e não Direito:

O primeiro, abarca a produção normativa de signo estatal, com ênfase, portanto no poder público, é abstrato, impessoal, 
cogente, baseado na soberania do território e gerador de normas que ostentam, grosso modo, efeitos ex nunc e incidem às situaçôes fáticas através de subsunção. O segundo, é forjado e congrega a produção normativa oriunda da iniciativa privada, detém, por isso, nítido caráter de poder privado, é concreto, pessoal, cogente ou consensual, excepciona fronteiras e varre territórios e dá azo a normas de efeitos ex tunc, que são aplicadas às relaçóes por meio de expedientes arbitrados (de busca concorde) ou regulados (autorregulação regulada).

Para Fornasier e Ferreira (2015, p. 309), as ordens jurídicas de autorregulação global não estão totalmente alheias à regulamentação estatal, e seu bom desempenho depende de eficiência estrutural conjunta entre a ordem jurídica estatal e a ordem jurídica não estatal de autorregulação:

[...] há regramentos para além daqueles positivados pelo Estado-nação que se efetivam no tocante a estes assuntos, e que não estão, necessariamente, em desenvolvimento paralelo ao regramento estatal: pode haver uma confluência entre o Direito de cada Estado-nação, entre o Direito Internacional e o Direito que nasce em âmbitos transnacionais, que "transbordam" a ideia de estatalidade e dela não são dependentes.

A autorregulação, segundo Caletti e Staffen, (2019), assume três funcionalidades principais: (a) como mecanismos de normatização de condutas a partir de atos específicos em âmbito nacional, internacional e supranacional; (b) como expedientes para especificação de disposiçóes de normas provenientes dos poderes estatais; e (c) como práticas comparativas, com propósito de orientaçáo dos comportamentos jurídicos, políticos, sociais e institucionais para escolha de normas dotadas de maior efetividade, eficácia e eficiência.

Engelmann, Leal e Hohendorff (2018) afirmam que, embora os riscos de novas tecnologias sejam incertos e ocorram somente no futuro, a decisão é realizada no presente e, com isso, o direito deve desenvolver respostas adequadas às demandas surgidas em função dessa nova realidade, e complementam:

Diferentemente dos riscos da modernidade, os riscos que resultam das novas tecnologias e do processo de industrialização são resultados de decisóes conscientes (tomadas por um lado por organizaçōes provadas e/ou estatais para obter vantagens econômicas e aproveitar as oportunidades correspondentes e, por outro lado, sobre a base de um cálculo que considera os perigos como a inevitável face oculta do progresso). 
Sobre a autorregulamentação em sociedades tecnológicas, pautadas no avanço das tecnologias, esclarece $\operatorname{Diez}$ (2013, p. 16):

Hoje é fundamental ter em conta o fenômeno da autorregulação para elaborar os critérios de imputação coerentes com a nova realidade social e jurídica do Estado. Com efeito, na era do risco, os avanços técnicos estabeleceram um conflito fundamental entre sociedade, Estado e empresa. Assim, o Estado, na era da incerteza, perdeu o monopólio tanto da proteçấo de bens jurídicos, como da distribuiçấo de riscos e do planejamento estratégico, uma vez que simples e cheio, necessitava de informaçóes suficientes para poder desenvolvê-los. Isso se vê claramente na matéria ambiental na qual o Estado já náo dispóe do conhecimento e de recursos para poder regular corretamente os novos riscos ambientais.

A crescente "incerteza da ciência", faz-se referência a várias formas de indeterminaçóes do conhecimento no campo científico: a complexidade do conhecimento, a falta ou insuficiência de dados, a imprevisibilidade dos sucessos, o caráter estocástico das previsóes em muitos setores" (TALLACCHINI, 2004, p. 87).

A autorregulaçáo através do cumprimento de documentos regulatórios das agências reguladoras e organizaçōes de normalização técnica, pode atender aos requisitos de proteçâo ao ser humano e meio ambiente, utilizando a comunicação como o norte a ser seguido em todas as etapas dos processos internos, serviços prestados e produto (levando-se em conta as cláusulas contidas em convençáo coletiva por exemplo; considerando-se também a questáo da rotulagem dos produtos e o direito à informaçáo) (MARTINS, 2016, p. 90).

Nesse contexto, a título de exemplo, tem-se a governança por instituições privadas com funçóes regulatórias, como é o caso da Organizaçáo Internacional para Padronização (International Organization for Standardization - ISO), que adota, em nível mundial, normas e padróes para a harmonização de produtos e processos para indústrias de tecnologia, segurança alimentar, agricultura e saúde. Suas normas padronizadoras e decisóes causam impacto econômico e servem de base para decisóes de autoridades baseadas em tratados, por exemplo, a Organização Mundial do Comércio (OMC) (KINGBURY; KRISCH; STEWART, 2005, p. 23). Trata-se de: 
[...] uma rede de corpos nacionais de padronização técnica, que, em alguns casos, são partes da estrutura governamental dos seus Estados; em outros, são organizaçôes do setor privado. A Associação Brasileira de Normas Técnicas (ABNT), de caráter privado, representa o Brasil na ISO" [... A A instituiçấo e o reconhecimento da ISO, por parte dos países que dela fazem parte, denota a existência de uma organização formal que, valendo-se de um Direito Global pretende aumentar (qualitativa e quantitativamente) o fluxo de transaçóes econômicas (FORNASIER; FERREIRA, p. 303).

Como um novo instrumento jurídico, a autorregulação passa a ser um elemento transnormativo da regulação das novas tecnologias, uma vez que os atores globais impóem seus padrões, conforme se observará no tópico seguinte, por meio da análise da ISO/TC229 e a governança de seus riscos socioambientais.

\section{Autorregulaçáo e governança dos riscos socioambientais das novas tecnologias: problematizaçóes a partir da norma ISO/TC 229}

No campo da ciência e tecnologia, conforme visto anterior, é usual a imposição de padróes ${ }^{9}$ por meio de normas internacionais, nacionais ou mesmo privadas. Padróes ditos formais, globalmente reconhecidos, são desenvolvidos por especialistas e aprovados por conselhos ou organizaçóes internacionais, entre os quais se incluem ISO, IEC, JIS e DIN.

Com a emergente expansão da nanotecnologia a partir dos anos 2000, comunidades internacionais organizaram-se para debater e criar normas que garantissem a implementação bem-sucedida desses novos desenvolvimentos na indústria. Em 2005, liderado pelo Instituto de Padróes Britânicos (BSI), em cooperação com institutos de outros países, foi estabelecido o Comitê Técnico para nanotecnologias da ISO, denominado ISO/TC 229.

O escopo da ISO/TC 229 consiste no estabelecimento de normas e demais diretrizes que suportassem o desenvolvimento, a disseminação, a comercialização e a evolução da nanotecnologia, além de todos os aspectos legais, sociais e ambientais a ela ligados. É o que se verifica no plano estratégico original da ISO/TC 229 para 2005 a 2010, na seção de objetivos:

9 De acordo com o guia da ISO/IEC de 2005, um padrão é um "documento, estabelecido por consenso e aprovado por uma associação reconhecida, que fornece, para uso comum e repetido, regras, diretrizes ou características para atividades ou seus resultados, destinado ao atingimento do grau ótimo de ordem em um dado contexto" (ISO/IEC. Guide 21-1: 2005, 3.1, tradução livre). 
[...] desenvolver padróes robustos e outros entregáveis relevantes às nanotecnologias que: suportem o desenvolvimento sustentável e responsável e a disseminação global dessas tecnologias emergentes; facilitar o comércio global de nanotecnologias e de produtos e sistemas nano-habilitados; suportar melhorias de qualidade, segurança, proteçáo ambiental e ao trabalhador e consumidor, junto ao uso racional dos recursos naturais no contexto de nanotecnologias; promover boas práticas na produção, uso e disposição de nanomateriais, produtos nanotecnológicos e sistemas e produtos habilitados pela nanotecnologia (ISO, 2014, tradução livre).

Um aspecto relevante a ser observado sobre a criação da ISO/TC 229 é seu caráter antecipatório, ou seja, a introdução de padrôes e instrumentos regulatórios antes da efetiva comercialização e maturação dos produtos e processos por ela relacionados. Essa normatização antecipada foi bem justificada por Willis (2009, p. 22) durante a Conferência Internacional sobre Nanotecnologia para a Indústria de Produtos Florestais em 2009:

Padrôes ajudarão a garantir que a nanotecnologia seja desenvolvida e comercializada de uma maneira aberta, segura e responsável por suportar: testes de segurança, legislação e regulação; segurança ambiental, pública e do trabalhador; comercializaçáo e aquisição, patenteamento e direitos de propriedade intelectual; comunicação sobre os benefícios, oportunidades e potenciais problemas associados com nanotecnologias. Isso será alcançado ao fornecer normas de: nomenclatura, descrição, especificação, medição e teste; protocolos para saúde e testes de segurança ambiental; avaliaçáo e gerenciamento de risco (tradução livre).

Tratando-se da novidade tecnológica, da ausência de uma base sólida de conhecimento e, especialmente, dos potenciais riscos associados aos produtos e processos nanotecnológicos, justifica-se tamanha preocupação da comunidade internacional em antecipar a normatizaçáo da nanotecnologia.

Em notícia intitulada "ISO leads collaboration on nanotech standards" (ISO LEADS..., 2009), publicada na mídia eletrônica Chemical Watch, o então presidente do TC 229, Dr. Hatto, ressaltou: "De importância fundamental para o futuro das nanotecnologias é a preocupação e a incerteza sobre os impactos dos nanomateriais na saúde e no meio ambiente". No mesmo sentido, Chris Bell, membro da equipe de negociação da ISO para os Estados Unidos, reforçou: 
Padrôes estão sendo desenvolvidos nas áreas de medição da exposição, identificação de perigos e análise de risco. Um dos principais desafios frente a esse esforço é fornecer orientaçóes sobre como comercializar com credibilidade a nanotecnologia na ausência de informaçōes perfeitas.

Observa-se claramente a preocupação dos órgãos internacionais em assegurar não somente a captura do enorme potencial da nanotecnologia, mas, essencialmente, sua implementação segura na sociedade:

À medida que a tecnologia avança, as necessidades da comunidade têm se alterado em relação aos padrôes necessários para garantir a sua implementação bem-sucedida. Muitas das necessidades dos padróes "fundamentais" de nanotecnologia, conforme abordado pelo primeiro presidente do ISO/TC 229, Dr. Peter Hatto: Como chamar (terminologia); como medir (metrologia); e qual é o seu impacto (saúde, segurança, meio ambiente), estão agora estabelecidos e sendo usados como a base com a qual a comunidade de nanotecnologia considera e desenvolve padrôes específicos da indústria (ANSI-NSP, 2019, tradução livre).

A fim de tratar adequadamente de toda a problemática do tema e alcançar os objetivos definidos no plano estratégico original, o Comitê Técnico ISO/TC 229 estrutura-se, atualmente, em cinco grupos de trabalho (working groups - WGs), cada qual responsável por uma categoria de padróes:

Cinco categorias de padrôes horizontais estão sendo desenvolvidas; padrōes de terminologia e nomenclatura definem uma linguagem comum para processos científicos, técnicos, comerciais e regulatórios; padrôes de medição e caracterização fornecem uma base internacionalmente aceita para atividades quantitativas científicas, comerciais e regulatórias; as normas de saúde, segurança e meio ambiente melhoram a segurança ocupacional, a proteção ao consumidor e ao meio ambiente e promovem boas práticas na produçáo, uso e descarte de nanomateriais, produtos nanotecnológicos e sistemas e produtos nano-habilitados; os padróes de especificação de materiais especificarão as características relevantes dos materiais fabricados em nanoescala para uso em várias aplicaçóes; e os padróes baseados em desempenho de produtos e aplicativos destacarão as vantagens dos produtos nano-habilitados e nano-aprimorados (ISO, 2019a, tradução livre). 
O ISO/TC 229 reúne 55 países-membros, sendo 34 participantes, incluindo o Brasil, e 21 observadores. Além disso, os grupos de trabalho (WGs) apresentam interligaçôes com os demais comitês da ISO, com o comitê técnico International Eletrotechnical Commision (IEC/TC 113) e outras organizaçôes internacionais, como a European Comission (EU) e a Organisation for Economic Co-operation and Development (OECD). Como resultado, na base de documentos constam 72 padróes publicados, incluindo suas atualizaçóes e mais 40 padróes em desenvolvimento (ISO, 2019b).

Em adição aos trabalhos dos comitês da ISO e da IEC em nível internacional, uma série de programas nacionais vêm trabalhando desde 2004 no campo da regulação das nanotecnologias. Comitês formados dentro dos órgãos nacionais de padronização, como o BSI/NT1, no Reino Unido, o SAC/TC 279, na China, o ANSI-NSP, nos Estados Unidos, e outras organizações, como ASTM e IEEE, têm produzido uma série de documentos reguladores, o que tem contribuído e influenciado de maneira significativa os padróes internacionais (MANTOVANI; PORCARI, 2010).

O American National Standards Institute (ANSI), que representa os Estados Unidos no TC/229 e lidera o chamado WG3, é responsável por conduzir os trabalhos nas áreas de saúde, segurança e aspectos ambientais da nanotecnologia. De acordo com Fen (2016), no rol do WG3, até 2016 constavam 13 normas já publicadas e 21 projetos em andamento, classificados nos seguintes subgrupos: (a) triagem toxicológica de nanomateriais; (b) controle de exposiçóes ocupacionais a nanomateriais; (c) determinaçâo da toxidade relativa/risco potencial dos nanomateriais; (d) uso ambientalmente correto de nanomateriais; (e) garantia da segurança de produtos feitos de nanomateriais.

Apesar de todo o trabalho em curso e dos instrumentos normativos já em vigor, entende-se que a base de conhecimento ainda não é suficiente para mitigar todo um universo de riscos associados à nanotecnologia, haja vista o extenso leque de nanomateriais continuamente apresentado ao mercado. Nos campos ainda descobertos pelos padróes regulatórios, a comunidade internacional reforça a prática cautelosa, defensiva e preventiva por parte dos fornecedores de produtos e processos nanotecnológicos, como meio fundamental de garantir a proteção da saúde humana e do meio ambiente (MANTOVANI; PORCARI, 2010).

Por outro lado, verifica-se um forte engajamento da comunidade internacional, representada, especialmente, pela ISO/TC 229 e suportada por uma extensa rede de organizaçôes ao redor do mundo, em prol da contínua concretização do plano estratégico traçado em 2005 para o estabelecimento de normas e diretrizes que suportem o desenvolvimento responsável da nanotecnologia. 
No campo da ciência e tecnologia, padróes representam as melhores práticas, permitem a comparaçáo entre produtos e sistemas, facilitam a aceitação pelos consumidores, são estabelecidos por consenso de todas as partes interessadas e, portanto, formam a base de regulaçóes (CLIFFORD, 2017).

Nesse contexto, é indiscutível o papel da ISO/TC 29 como principal instrumento autorregulatório das nanotecnologias para a governança dos riscos à saúde, à segurança e ao meio ambiente.

\section{Conclusão}

Vive-se em um período no qual as novas tecnologias avançam rapidamente. Além disso, os Estados encontram dificuldades para enfrentar os riscos socioambientais deles advindos por meio de sua governança.

Emerge a possibilidade de regulação internacional das novas tecnologias estabelecendo padróes técnicos a serem observados por agentes econômicos e Estados em âmbito transnacional.

Embora a autorregulação possa provocar uma redução da regulação estatal, os fatores positivos dela advindos demonstram-se efetivos, na medida em que pode ser realizada pelos próprios agentes, com capacidade e conhecimento técnico específico sobre o tema, como no caso da ISO/TC 229.

O campo das nanotecnologias é um exemplo latente, pois, embora já não mais se discuta sua importância, seu valor econômico e a melhoria na qualidade de vida das pessoas, seu uso e sua produçáo em grande escala para o mercado consumidor pode trazer consigo possíveis riscos socioambientais.

Notadamente, tais normas autorregulatórias por vezes cobrem eventuais lacunas de caráter legal interno dos países e buscam qualidade na regulação, com vistas às diferentes demandas do mercado.

Isto posto, conclui-se a, partir da análise da ISO/TC229, que a autorregulação passa a ser um elemento transnormativo da regulação das novas tecnologias, uma vez que impóem seus padróes os atores globais de governança de riscos socioambientais.

\section{Referências}

ABNT - ASSOCIAÇÃO BRASILEIRA DE NORMAS TÉCNICAS. Normalização. Disponível em: <http://www.abnt.org.br/normalizacao/o-que-e/o-que-e>. Acesso em: 11 set 2019.

ALVES, B. S. F. Por uma teoria crítica das relaçôes internacionais: as contribuições 
de Jürgen Habermas. São Paulo: Cultura Acadêmica, 2014.

ANSI-NSP. ANSI-NSP Newsletter. ANSI Nanotechnology Standards Panel, v. 5, n. 1, 2019. Disponível em: <https://share.ansi.org/Shared\%20Documents/ Standards\%20Activities/ANSI-NSP/Newsletter/ANSI_NSP_Newsletter_ Vol_V_Issue_I_April_2019.pdf>. Acesso em: 27 jul. 2019.

ARCURI, A. S. A.; PINTO, V. R. S. Nanotecnologia: riscos emergentes e novas formas de prevenção num mundo do trabalho em transformação. Rio de Janeiro: Fundacentro, 2010. Disponível em: <http://www.fundacentro.gov.br/dominios/ CTN/anexos/ARline\%20Sydneia\%20Abel.pdf>. Acesso em: 10 ago. 2019.

BARBOSA, L. N. O processo civil brasileiro como veículo de concretização e juridicização de normas globais ("global law"). Dissertação (Mestrado em Direito) - Programa de Pós-Graduação em Direito Processual, Universidade Federal do Espírito Santo, Vitória, 2017.

BAUMAN, Z. Globalizaçẫo: as consequências humanas. Rio de Janeiro: Zahar, 1999.

BAUMAN, Z. A sociedade individualizada: vidas contadas e histórias vividas. Rio de Janeiro: Zahar, 2008.

CALETTI, L.; STAFFEN, M. R. A fragmentação jurídica e o direito ambiental global. Veredas do Direito, Belo Horizonte, v. 16, n. 34, p. 279-310, jan./abr. 2019.

CANOTILHO, J. J. G. Estado de Direito. Lisboa: Gradiva, 1999. Disponível em: <http://pt.scribd.com/doc/43038759/Canotilho-Estado-de-Direito-LIVRO>. Acesso em: 27 jul. 2019.

CICCO, C.; GONZAGA, A. A. Teoria Geral do Estado e ciência politica. São Paulo: Revista dos Tribunais, 2008.

CLIFFORD, C. Standards and their value in general and specifically for nanotechnology. In: Commercialization of nanomaterials: process, issues, and management. London, 2017. Disponível em: <www.rsc.org/events/download/ Document/1ebfc5bf-48ca-48e4-a6be-9065bccb508c>. Acesso em: 27 jul. 2019.

DIEZ, C. G. A responsabilidade penal da pessoa juridica e o dano ambiental: a aplicação do modelo construtivista de autorresponsabilidade a Lei 9605/98. Porto Alegre: Livraria do Advogado, 2013.

ENGELMANN, W.; LEAL, D. W. S.; HOHENDORFF, R. V. Autorregulação e riscos: desafios e possibilidades jurídicos para a gestáo dos resíduos 
nanoparticulados. Revista da Faculdade de Direito da UFRGS, Porto Alegre, v. esp., n. 39, p. 211-232, dez. 2018.

FEN, L.B. ISO Standard on nanomaterials. In: OECD EHS programme: chemical and nanomaterial management, 2016. Disponível em: <http://www.jsm.gov. my/documents/10180/2283376/7.+ISO+standard+on+Nanomaterials_IKM. pdf/9ea59b6a-21b1-49ba-a634-d12bbeb3e6ff>. Acesso em: 27 jul. 2019.

FORNASIER, M. O.; FERREIRA, L. V. Autorregulação e direito global: os novos fenômenos jurídicos não-estatais. Revista do Programa de Pós-Graduação em Direito da UFC, Fortaleza, v. 35, n. 2, p. 295-312, jul./dez. 2015.

FRAGOSO, A. Nanotecnologia e meio ambiente. Disciplina especial em ciências ambientais. Mestrado em Ciências Ambientais. Chapecó: Unochapecó, 2010.

ISO - INTERNATIONAL ORGANIZATION FOR STANDARDIZATION. Report of WG Standardization in Nanofutures, 2014. Disponível em <http://www. nanofutures.eu/sites/default/files/Nanofutures\%20WG\%20Standardization $\% 20$ Report\%20November\%202014\%20Stintz.pdf>. Acesso em: 27 jul. 2019.

ISO - INTERNATIONAL ORGANIZATION FOR STANDARDIZATION. ISO/TC 229: business plan, 2019a.

ISO - INTERNATIONAL ORGANIZATION FOR STANDARDIZATION. ISO/TC 229, 2019b. Disponível em: <https://www.iso.org/committee/381983. html>. Acesso em: 27 jul. 2019.

ISO LEADS collaboration on nanotech standards. Chemical Watch, nov. 2009. Disponível em: <https://chemicalwatch.com/2914/iso-leads-collaboration-onnanotech-standards>. Acesso em: 27 jul. 2019.

KINGSBURY, B.; KRISCH, N.; STEWART, R. B. The emergence of global Administrative Law. Law and Contemporary Problems, v. 68, n. 3, p. 15-62, jul./ dez. 2005. Disponível em: <http://scholarship. law.duke.edu/lcp/vol68/iss3/2>. Acesso em: 27 jul. 2019.

LIMA, G. G. B. Conceitos de relaçôes internacionais e teoria do direito diante dos efeitos pluralistas da globalização: governança global, regimes jurídicos, direito reflexivo, pluralismo jurídico, corregulaçáo e autorregulação. Revista de Direito Internacional, Brasília, DF, v. 11, n. 1, p. 216-229, 2014.

MANTOVANI, E.; PORCARI, A. Developments in Nanotechnologies Regulation and Standards 2010: report of the Observatory Nano, 2010. Disponível em: <http:// www.nanotec.it/public/wp-content/uploads/2014/04/ObservatoryNano_ 
Nanotechnologies_RegulationAndStandards_2010.pdf>. Acesso em: 27 jul. 2019.

MARTINS, P. S. O sistema de normas ISO e as nanotecnologias: as interfaces regulatórias e o diálogo entre as fontes do direito. Dissertaçáo (Mestrado em Direito) - Programa de Pós-Graduação em Direito, Universidade do Vale do Rio dos Sinos, São Leopoldo, 2016. Disponível em: <http://www.repositorio.jesuita. org.br/handle/UNISINOS/6206>. Acesso em: 27 jul. 2019.

MENEZES, W. O direito internacional contemporâneo e a teoria da transnormatividade. Pensar, Fortaleza, v. 12, p. 134-144, mar. 2007.

NISTLER, R. Transnacionalismo: uma nova dinâmica estatal. Revista da AGU, Brasília, DF, v. 17, n. 3, p. 295-326, jul./set. 2018.

PEREIRA, C. S.; RAMOS, L. C. S.; SANTOS FILHO, O. Governança global, governamentabilidade e uma nova visão acerca da relação entre explicaçáo e compreensão nas relaçóes internacionais. In: 3o ENCONTRO NACIONAL ABRI: GOVERNANÇA GLOBAL E NOVOS ATORES, 3., São Paulo, 2011. Anais [...]. Belo Horizonte: ABRI, 2011. Disponível em: <http://www. proceedings.scielo.br/pdf/enabri/n3v3/a29.pdf>. Acesso em: 27 jul 2019.

TALLACCHINI, M. Principio de precaución y bioseguridad: aplicación a la salud humana. In: ROMEO CASABONA, C. M. (Ed.). Principio de precaución, biotecnología y derecho. Granada: Comares, 2004. p. 85-98.

TROCHE, K. S. Estudo estrutural e eletrônico de fulerenos e diamondóides encapsulados em nanotubos de carbono. Tese (Doutorado em Ciências) - Instituto de Física Gleb Wataghin, Universidade Estadual de Campinas, Campinas, 2007.

WILLIS, C. ISO TC 229 International standards for nanotecnology. In: 2009 INTERNATIONAL CONFERENCE ON NANOTECHNOLOGY FOR THE FOREST PRODUCTS INDUSTRY, 2009, Edmonton. Disponível em: $<$ https://www.tappi.org/content/events/09nano/papers/09nan45.pdf>. Acesso em: 27 jul. 2019. 


\title{
A MEDIAÇÃO COMO MEIO EMANCIPADOR DO CONF̌LITO E RESGATE DA CIDADANIA
}

\author{
Janete Rosa Martins ${ }^{1}$ \\ Universidade Regional Integrada do Alto Uruguai e das Missóes (URI)
}

Artigo recebido em: 26/08/2019.

Artigo aceito em: 30/09/2019.

\section{Resumo}

O presente artigo tem como objetivo estudar a mediação como meio emancipatório do conflito e o resgate da cidadania nos atores envolvidos em controvérsias. Essas controvérsias ocorrem em virtude da falta de diálogo, autonomia e sensibilidade. Para estudar mediação, conflitos e cidadania, foi utilizado o método hipotético-dedutivo, a partir de um problema com a verificação de hipótese. Discute-se a teoria do conflito, mediação e cidadania. Constata-se que a sociedade contemporânea vive um momento de muitos conflitos sociais por falta de entendimento, diálogo e consenso. Sendo assim, para a construção da autonomia entre os atores em conflito, surge um terceiro imparcial denominado mediador, cuja função é aproximar e restaurar os laços rompidos. Esse procedimento denomina-se mediação, que é o meio efetivo para a compreensão e o resgate da cidadania, e está inserido no contexto dos direitos humanos. O processo requer um diálogo respeitoso, com sensibilidade, solidariedade e transformação para a concretização dos direitos e da paz social.

Palavras-chave: cidadania; conflito; direitos humanos; mediação; solidariedade.

\section{THE MEDIATION AS MEANS OF EMANCIPATION OF CONFLICT AND RESCUE OF CITIZENSHIP}

\section{Abstract}

This article aims to study mediation as an emancipatory means of conflict and citizenship rescue in actors involved in controversies. These controversies occur because of the lack of dialogue, autonomy and sensitivity. To study mediation,

1 Doutora em Ciências Sociais pela Universidade do Vale do Rio dos Sinos (UNISINOS). Mestre em Direito pela Universidade de Santa Cruz do Sul (UNISC). Especialista em Direito Público e bacharel em Direito pela Universidade Regional do Noroeste do Estado do Rio Grande do Sul (UNIJUÍ). Professora da graduação e pós-graduação stricto sensu em Direito. Editora da Revista Direito e Justiça: Reflexões Sociojurídicas. Pesquisadora em mediação. ORCID: http://orcid.org/0000-0002-8014-8237 / e-mail: janete@san.uri.br 
conflicts and citizenship, the hypothetical deductive method was used, based on a problem with hypothesis verification. It discusses the theory of conflict, mediation and citizenship. It can be seen that contemporary society is experiencing a time of many social conflicts due to lack of understanding, dialogue and consensus. Therefore, for the construction of the autonomy among the conflicting actors, an impartial third party called the mediator emerges, which function is approximating and restoring the broken ties. This procedure it is called mediation, an effective means for understanding and rescuing citizenship, and is inserted in the context of human rights. The process requires a respectful dialogue, with sensitivity, solidarity and transformation for the realization of rights and social peace.

Keywords: citizenship; conflict; human rights; mediation; solidarity.

\section{Introdução}

O presente artigo tem como objetivo discutir a mediação como meio emancipador do conflito entre os atores envolvidos. Está dividido em duas partes: na primeira, discute-se a teoria do conflito e suas especificidades, em seguida, a mediação como modo emancipatório e o resgate da cidadania. O método hipotético-dedutivo questiona de que maneira a mediação é um meio emancipatório do conflito e como pode ser efetivada a cidadania. Para que se possa responder a esse questionamento, precisa-se necessariamente trabalhar a teoria do conflito e suas especificidades, os envolvidos na adversidade e a mediação como meio emancipatório. O conflito pode ser salutar, desde que seja possível resolver suas diferenças com base na sensibilidade e no entendimento mútuo. A subjetividade, nesse contexto, deve ser constante entre os atores em uma relação conflitiva para a emancipação e o resgate da cidadania.

\section{A teoria do conflito e suas especificidades}

O Estado, por meio da instituição do Poder Judiciário, em tese, resolve ou pressupóe-se a resolver os conflitos de interesses, tanto individuais quanto coletivos, com base na criação de uma determinada norma particular de aplicação ao caso concreto, de maneira que ela seja o contorno justo e adequado para garantir a tutela. Observa-se nesse processo, então, as garantias processuais das partes consagradas no ordenamento jurídico. Entretanto, para que isso ocorra, é relevante haver equilíbrio entre a celeridade e a legitimidade processual, que são elementos 
importantes para as políticas públicas de inclusão social por meio do acesso à justiça, bem como a utilização dos mecanismos extrajudiciais de recomposição de compromissos de acordo com a legislação socialmente legitimada. Assim, parece se instaurar um amplo acesso à resolução dos conflitos oriundos das atividades e relaçóes entre os sujeitos, sem deixar de lado a garantia cidadá da população. Nesse sentido, a mediaçáo se insere como um meio de acesso à justiça de maneira extrajudicial a fim de resgatar a cidadania e promover a emancipação do conflito entre os atores.

$\mathrm{O}$ atual momento tanto no Brasil quanto no mundo referente às crises financeiras e de poderes leva a refletir e a procurar outras formas de resolver os conflitos que aqui se apresentam. E, parafraseando Bedin, Bedin, Fischer (2013, p. 15) "a figura estatal perde poder diante da complexidade do mundo atual, em especial em sua prerrogativa de dizer o Direito", isto é, aquilo que abre espaço para novos meios de solucionar os conflitos, completam Brandt e Brandt (2016).

A partir disso, começa-se a discutir a teoria do conflito, suas especificidades e o uso da mediação. É necessário lembrar do poema "Canção do Tamoio", de Antônio Gonçalves Dias, que diz "Viver é lutar". Essa expressão apresenta uma percepção do conflito. $\mathrm{Na}$ sociedade atual somos lutadores efêmeros para o reconhecimento, a distribuição e a proteção dos direitos humanos, como diz o verso "Viver é lutar" (ALCÂNTARA JÚNIOR, 2005). A definição da teoria do conflito que se adequa à questão é feita por Georg Simmel (1983 apud ALCÂNTARA JÚNIOR, 2005, p. 8), na qual o fato que altera o conflito inexoravelmente e a resposta que se dá a isso é o que o torna construtivo ou destrutivo. Caso se configure como destrutivo, ele compor-se-á de fatores de dissociaçáo como a intolerância, o ódio, a inveja, a contingência e o desejo, por exemplo. Segundo Simmel (1983 apud ALCÂNTARA JÚNIOR, 2005, p. 8), esses pontos são as causas do conflito. $\mathrm{O}$ autor define, ainda, o conflito como o resultado das interaçôes sociais, tendo na antagonia de comportamentos e sentimentos sua razão de ser e funcionando como mola propulsora do progresso.

Nesta perspectiva, os conflitos sociais são destacados como socialmente importantes. São formas prevalecentes nas interaçôes de convivência social. Simmel aponta uma das virtudes do conflito. Este atributo positivo residiria no fato de que ele, - o conflito - cria um patamar, um tablado social, à semelhança de um palco teatral, espaço onde as partes podem encontrar - se em um mesmo plano situacional e, desta maneira, impóe - se um nivelamento. Uma condição necessária para que as partes, às vezes, ásperas e díspares, possam, de fato, efetuar a trama que ele encerra. [...] O conflito possui a capacidade de constituir - se 
num espaço social, em que o próprio confronto é um ato de reconhecimento e, ao mesmo tempo, produtor de um metamorfismo entre as interaçôes e as relaçóes sociais daí resultantes. Uma outra característica positiva atribuída, residiria no fato de superar os hiatos e os limites socialmente estabelecidos pelos intervalos dicotomizados, ou mesmo, as desigualdades sociais produzidas e estruturadas pelos resultados dos entrelaçamentos ocorridos na sociedade. Para Simmel, o conflito é a substância existente nas mais diversas relaçōes entre os indivíduos na sociedade (ALCÂNTARA JÚNIOR, 2005, p. 7).

Segundo Warat (2001, p. 7), "o conflito é algo que precisa ser sentido", analisado; encontra-se no interior de cada ator. As diversidades existentes tendem a ser muitas vezes causadas por desentendimentos mútuos, ressentimentos, decepçóes não trabalhadas. Os desentendimentos iniciam em pequenos grupos e, na maioria das vezes, se expande para grandes grupos como uma controvérsia, gerando conflitos sociais que abrangem a sociedade. Esses conflitos, se configuram:

A discussão conceitual sobre o conflito é de vital importância, já que através dela poderemos sistematizar alguns aspectos que venham retratar por exemplo, os momentos dos passageiros de ônibus em uma cidade, principalmente junto aos microconflitos existentes, em parte, existentes na rotina do(a) morador(a) de uma cidade. Ao identificar este componente como uma porção constante da dinâmica que se processa nas relaçôes sociais (ALCÂNTARA JÚNIOR, 2005, p. 13).

Os conflitos implicam em mudanças de atitudes. Para Hellinger (2019, p. 13), "todo o grande conflito pretende remover algo do caminho, outra coisa que estimula o conflito é a consciência que nos leva para o bem ou mal”. A consciência nos leva a considerar novas crenças e comportamentos, fazendo que visóes tidas como corretas sejam reavaliadas e rediscutidas, construindo-se usualmente a alternativa para pautarmos nossa visão pela análise do caráter social e histórico das relaçôes e nessas situarmos os conflitos que enunciamos explorar.

Segundo Rosenberg (2019, p. 49), "sentimentos podem ser usados de uma forma destrutiva se insinuarmos que os comportamentos das outras pessoas são as causas de nossos sentimentos. A causa dos nossos sentimentos são nossas necessidades e não o comportamento dos outros". Nesse contexto, Nogueira aponta para contradiçóes e paradoxos a serem considerados em um processo de mediação, como os

[...] três desafios impostos pela modernidade radicalizada à democracia política: a disposiçẫo participativa, as pressóes 
identitárias e a individualização. Impulsionadas pelas mudanças trazidas pela dinâmica dessa modernização, as sociedades se fragmentam mais e suas partes (grupos, indivíduos, regiôes) passam a seguir lógicas próprias - ainda que, paradoxalmente, tudo fique mais conectado (NOGUEIRA, 2014, p. 457).

Nessa ótica, pode-se prever um grande conjunto de obstáculos aos processos de mediação se junto a iniciativas de inclusão convive um sentimento de desumanização ou coisificação. Na visão sociológica de Martins (2008), essas circunstâncias compreendem uma multiplicidade de dolorosas experiências cotidianas de privações, de anulaçóes e também de inclusão enganadoras. Cabe destacar a dimensão paradoxal em curso, conforme assinala Therborn:

Quando se trata da produção de desigualdade via distanciamento, estamos em face de um paradoxo do nosso tempo. Em um sentido territorial, as distâncias encolheram enormemente. Mas as distâncias vitais e de renda estâo aumentando entre partes diferentes do mundo e dentro de muitos países (THERBORN, 2010, p. 150).

Em outros termos, trata-se de abordar um processo percebido por meio de uma trajetória de vida em que as experiências consagram uma visão de mundo. Entretanto, o conflito também pode ser a ocasiáo para que as pessoas se distanciem umas das outras, deixando de lado a compreensão e o diálogo. Essa intolerância e falta de respeito ao outro vêm da ausência de comunicação entre os atores envolvidos. Diante dessa realidade, emerge a proposição de restabelecer formas de comunicação, de reconhecimento e de outras virtudes relativas à convivência.

O campo de implementação e disseminação das práticas e saberes relativos às alternativas de justiça é bastante heterogêneo, assim como são diversas as suas avaliaçóes. Há, porém, um discurso mais ou menos homogêneo quanto ao seu ideário, que está voltado para a comunicação entre os indivíduos, a responsabilização das partes em conflito, o protagonismo delas, e para a busca de uma sociedade integrada, conjugando noções de autogestão, escolhas éticas dos indivíduos e a promoção de uma "cultura de paz" (OLIVEIRA, 2011, p. 193).

Haja vista as alteraçóes e um viés mais complexo das relaçôes sociais, o conceito de justiça sofre transformaçôes, torna-se mais amplo e moderno e projeta-se um ideal em que se possibilita a todos a maneira igualitária desse pleito. Sendo assim, lidar com os conflitos surge como um meio alternativo em diferentes aspectos. Conforme Arendt (1997, p. 32), "o homem é, por natureza, político; isto é, 
social. Melhor que qualquer teoria complicada, é essa substituição inconsciente do social pelo político, que revela até que ponto a concepção original grega de política havia sido esquecida [...]".

Considerando a exigência de um espaço no qual cada cidadão possa ser julgado por suas açóes e palavras - e não por sua origem ou raça -, Arendt defende "o direito a ter direitos". Segundo Lafer, no entendimento de Arendt, a cidadania é concebida como o direito a ter direitos, "pois sem ela náo se trabalha a igualdade que requer o acesso ao espaço público" (1997, p. 64). E o conflito precisa ser trabalhado no espaço público social com o inuito de fazer-se entender que uma sociedade necessita de forças de repulsão e de atração, de tendências positivas e negativas para que assim possa haver o entendimento por meio das diferenças.

De fato, o conflito social tem como principal objetivo a sensibilização da sociedade a respeito do problema enfrentado - que tende a ser de um grupo ou de vários grupos -, com a finalidade de se alcançar um propósito. $\mathrm{O}$ conflito pode ser a oportunidade de concretizar um acordo que responsabilize sujeitos de direitos, pois é por meio deles que se consolidam as mudanças de atitudes, de crenças e de comportamentos. Tais mudanças são conquistadas pela reavaliação das questóes durante a resoluçấo dos problemas. Nesse sentido, um dos destaques da mediação é o fato de trabalhar a subjetividade do conflito, ou seja, o viés não verbalizado $\mathrm{e}$ que se esconde no conteúdo latente do problema, que, frequentemente, é diferente do conteúdo manifesto do conflito.

Entretanto, para Bertaso e Cacenote (2012), todas as minorias têm em comum a aspiração do reconhecimento político público de sua cultura. Essa multiplicidade e complexidade torna cada vez mais relevante a sintonia entre as práticas sociais com relação aos conflitos interindividuais, bem como suas repercussôes na sociedade. O conflito é a maneira utilizada pelos atores com o intuito de resolver dualismos divergentes, por exemplo, em grupos de interesses, organizaçóes e uniōes, e abrange diversas questôes enraivadas no seio desses atores. Para Muller, o conflito está na natureza das relaçôes sociais, pois "é significativo que os termos hostilidade e hospitalidade pertençam à mesma família etimológica: originalmente, as palavras latinas hostes e hospes designam ambas o estrangeiro. Este, com efeito, pode ser excluído como um inimigo ou acolhido como um hóspede" (2006, p. 6).

Uma característica complexa do conflito é a exclusão social dos atores em situação de vulnerabilidade, deixando-os à mercê de condiçôes mínimas de existência.

A contradição e o conflito, ao contrário, não só precedem a existência de indivíduos e grupos sociais, bem como operam em cada momento de sua existência. 
Isso significa que nas relaçóes sociais os pensamentos e correntes "convergentes e divergentes" encontram-se entrelaçados. Segundo Martins (2017, p. 244) "os juristas compreendem o conflito usualmente como algo a ser evitado e erradicado. Eles redefinem, pensando-o como litígio, como controvérsia ou adversidade [...] como condição intrínseca da sociedade contemporânea".

Para a lógica da justificação da ordem dominante,

Desigualdade alude a diversas possibilidades de acesso a bens e serviços e, principalmente, à possibilidade de o sujeito ser reconhecido e ouvido. Afirma-se que um mínimo de desigualdade é inerente e até necessário para a condição humana e que apenas seu excesso constitui um risco (MURILLO, 2007, p. 64, grifo da autora).

As desigualdades podem oferecer risco à governabilidade, visto que ela se ajusta como fundamentação para instaurar mecanismos alternativos de acesso à justiça. $\mathrm{Na}$ atualidade, existe igualmente uma incongruência entre as desigualdades persistentes e a governabilidade gerenciada pelos processos de mediação extrajudicial, que em última instância tem por base o direito legítimo à propriedade. Atualmente, muitos conflitos são causados pelas desigualdades entre os atores. Therborn cita três tipos de desigualdades:

[...] a desigualdade material ou de recursos, que significa que os atores humanos contam com recursos muito distintos. Podemos distinguir dois aspectos a esse respeito. A desigualdade de acesso à educação, à carreira e aos contatos sociais, ou seja, ao "capital social”. Nas discussóes convencionais, este aspecto é geralmente referido como "desigualdade de oportunidades". A desigualdade de recompensa, comumente denominada desigualdade de resultado. Esta é a medida de desigualdade mais frequentemente utilizada - a distribuição da renda e, às vezes, também da riqueza (THERBORN, 2010, p. 146).

Nessa perspectiva, adentra-se na questão de que as desigualdades levam os atores às distintas condições e inclusão social. Significa que o conflito gerado a partir da desigualdade material de oportunidades deixa os atores sociais afastados de suas reais precisóes de concretização. Assim, o acesso desigual a recursos a utilizar em sua ação social significa que os sujeitos sociais dispóem de acesso a mecanismos distintos para fazer-se presente no conflito de interesses. Isso é o que usualmente se tem, referindo como "desigualdade de oportunidades" (THERBORN, 2010, p. 146). 
A estruturação de cadeias de práticas concretas jamais apresenta-se independente das memórias coletivas e singulares que sedimentam os significados e as articulaçóes por meio da linguagem de comunicação com os outros. Nesse sentido, Murillo alerta:

Desse modo, pobreza e desigualdade são significantes que têm histórias diversas sedimentadas em camadas arqueológicas das memórias tanto em nível social, como subjetivo. Assim, portanto, o sentido brota numa dupla dimensão: por um lado, emerge da articulação horizontal dos significantes na cadeia dos intercâmbios discursivos, e, por outro, em cada ponto da cadeia pulsa um sedimento de histórias vividas (MURILLO, 2007, p. 41).

Dessa maneira, uma combinaçáo dialética entre o micro e o macro, entre ação e estrutura são significativos para pensar em mudanças quanto às práticas jurídicas. Outro aspecto já mencionado é desnaturalizar as desigualdades quando se trata de erradicar os obstáculos do acesso à mediação pública de controvérsias cotidianas. É também um acordo social que está posto em questão, porém, para isso, a percepçáo dos atores nesse direcionamento é fundamental. A questão das desigualdades sociais se concentra, principalmente, na questão do próprio sistema capitalista. Isso pode ser constatado na afirmação de Cattani, que diz:

Desigualdade econômica em níveis abissais, diferenças estratosféricas na distribuiçáo de renda, contrastes assombrosos entre riqueza e pobreza e outras formulaçôes igualmente expressivas são habitualmente empregadas para dar conta de desigualdades que, além de estarem sendo reproduzidas há séculos, se multiplicam em dimensōes inusitadas. [...]. Por vezes, as desigualdades são percebidas num primeiro nível, superficial, localizado e factual: carências alimentares de um lado, expressivos desperdícios por parte de privilegiados de outro; mansóes de altíssimo luxo a poucos metros de favelas miseráveis; milionários e seus animais de estimação dispondo de atendimento e recursos médicos avançados enquanto milhóes de indivíduos carecem de remédios e de cuidados básicos de saúde (CATTANI, 2007, p. 75).

Sendo assim, apesar das políticas públicas implementadas pelo governo federal como meio de diminuir a vulnerabilidade, vê-se, ainda, a presença de dois Brasis. Um Brasil da região sul e sudeste e outro Brasil, referente às regióes norte e nordeste do país, com alarmantes dados referentes à desigualdade, em virtude do sistema capitalista e do neoliberalismo. Tal sistema massacra naçóes e cria no 
Brasil uma linha abissal de desigualdades²; nesse caso, estão também incluídos os desníveis de renda e acesso à educação e cultura no sul do país. Entretanto, Souza afirma:

A tendência a se criar o que poderíamos chamar de "fetichismo da economia" - como se o crescimento econômico por si só pudesse resolver problemas como desigualdade excludente e marginalização -, o hábito de se estabelecer clivagens regionais entre partes modernas e tradicionais dentro do país ou ainda as cruzadas populistas contra a corrupção são legitimados por essa suposta herança pré-moderna e personalista, ideias que servem como máscara ideológica contra a articulação teórica e política dos conflitos específicos de classe na periferia (SOUZA, 2004, p. 80).

Em outros termos, significa afirmar que só o crescimento da economia não vai resolver o problema da desigualdade em naçóes periféricas como Brasil, como aponta o autor. Isso leva a crer que as questóes pertinentes de exclusão convergem com problemas passados que não foram resolvidos, gerando, atualmente, conflitos nas classes periféricas e inadequados encaminhamentos ao poder público. Portanto, cabe ao Estado disponibilizar espaços públicos que visem à inclusão desses atores com o intuito de sanar os conflitos em tais regiōes e, assim, reduzir a desigualdade. Parafraseando Warat (2001), precisamos desdramatizar o conflito para que possamos transformá-lo em sentimentos que acrescentem vivências na vida dos atores envolvidos na adversidade.

\section{A mediaçáo como meio emancipatório}

A sociedade está vivendo momentos conflitantes em seus diversos aspectos: social, emocional, moral, econômico, político e humano. Esses momentos conflitantes foram originários das promessas da modernidade de igualdade, liberdade e fraternidade, que não se concretizaram. A sociedade está cada vez mais desigual. Parafraseando Bauman (2001), estamos vivendo momentos de liquefação, nos quais o Estado náo consegue atender aos seus propósitos e enfraquece os serviços relativos à sociedade. Sendo assim, busca-se uma recomposição de compromissos de acordo com a legislação socialmente legitimada.

2 A este propósito convém conferir "O mito brasileiro e o encobrimento da desigualdade". In: SOUZA, J. A ralé brasileira: quem é e como vive. Colaboração de André Grillo et al. Belo Horizonte: Editora da UFMG, 2009, porquanto constrói um sentimento de pertencimento coletivo. 
Entretanto, o modelo estatal tradicional submete o cidadão ao Direito, em que o juiz está investido no poder de dizer o direito das partes, sem que essas participem da decisão. Tanto a sentença quanto o seu cumprimento configuram-se como uma imposição e as questôes emocionais latentes no conflito não são consideradas.

A prática tem demonstrado que essa nem sempre é a melhor solução e métodos alternativos começam a ganhar força, inclusive pelo Estado, com o uso de políticas públicas que visam democratizar as instituições do Poder Judiciário. Dentre esses novos métodos alternativos está a mediação, objeto de estudo do presente artigo.

A mediação compreende um instituto antigo, porém, neste estudo é relevante sua análise no contexto da vigência do Estado, como uma entidade responsável pelo controle e organização social. Aos poucos, surge outro modo de solucionar os conflitos, a autocomposição, que é utilizada para a resoluçáo parcial dos conflitos, como demonstram Cintra, Grinover e Dinamarco:

[...] uma das partes em conflito, ou ambas, abrem mão do interesse ou de parte dele. São três as formas de autocomposição (as quais, de certa maneira, sobrevivem até hoje com referência aos interesses disponíveis): a) desistência (renúncia à pretensão); b) submissão (renúncia à resistência oferecida à pretensão); c) transação (concessôes recíprocas). Todas essas soluçôes têm em comum a circunstância de serem parciais - no sentido de que dependem da vontade e da atividade de uma ou de ambas as partes envolvidas (CINTRA; GRINOVER; DINAMARCO, 2010, p. 17)

$\mathrm{Na}$ atualidade, as formas alternativas passam a ser estimuladas pelo Estado, pois, como asseveram os autores, "[...] a autocomposição, que não constitui ultraje ao monopólio estatal da jurisdição, é considerada legítimo meio alternativo de solução dos conflitos, estimulado pelo direito mediante as atividades consistentes na conciliaçãa” (CINTRA; GRINOVER; DINAMARCO, 2010, p. 35, grifos dos autores). Contudo, o modelo dominante de administração de conflitos passa por uma grande convulsão, sobretudo, uma crise de interpretação, como afirma Streck:

O enorme fosso existente entre o Direito e a sociedade, que é instituído e instituinte da/dessa crise de paradigma, retrata a incapacidade histórica da dogmática jurídica (discurso oficial do Direito) em lidar com a realidade social. Afinal, o establishment 
jurídico-dogmático brasileiro produz doutrina e jurisprudência para que tipo de país? Para que e para quem o Direito tem servido? Esse hiato e a crise de paradigma do modelo liberal-individualista-normativista retratam a incapacidade histórica da dogmática jurídica em lidar com os problemas decorrentes de uma sociedade díspar como a nossa (STRECK, 1999, p. 15, grifo nosso).

Nesse sentido, a mediação pode transformar o conflito porque visa trabalhar as diferenças e, como salienta Warat (1999, p. 5), "é uma forma ecológica de resolução de conflitos sociais e jurídicos [...] a mediação como uma forma ecológica de negociação ou de acordo transformador das diferenças".

Para que ocorra essa transformação, é necessário que as partes estejam dispostas à outridade (pela ecocidadania, transcidadania e direitos trans-humanos), ou seja, reencontrar o outro do conflito. Olhar para o outro com respeito e se colocar no lugar do conflitante, trabalhando sentimentos, diferenças, anseios, desejos a fim de buscar o amor e o entendimento com o outro. Direciona-se, assim, à subjetividade da ressignificação ética de valores imperativos universais interiorizados, a partir do outro.

A mediação para a emancipação acontece também pelos movimentos sociais, mas, para isso, é necessária a empatia que, segundo Krznaric (2019, p. 19), "precisamos reconhecer que a empatia não apenas nos torna bons, como nos faz bem, além disso deve ser colocada a serviço das grandes questóes de nosso tempo, como violência política, étnica, intolerância religiosa, pobreza, fome e abusos dos direitos humanos". Busca-se a inserção social e os direitos que se acham ausentes pela exclusão dos mais vulneráveis por meio de acordo com as demais instituiçóes do espaço público e tem como base a afirmativa de Alain Touraine:

Sua miséria, a exclusão e a repressão que eles sofrem é que dão ao seu protesto um valor fundamental. Porque é quando os problemas da vida privada e os da vida pública se unem da forma mais intensa para dar origem a um protesto cujo objetivo é a defesa da vida (TOURAINE, 1989, p. 86).

É importante que os movimentos sociais busquem uma esfera de reconhecimento e entendimento durante a realização do processo de mediação, visando aos direitos humanos e fundamentais, sendo o interlocutor. Nesse diapasão entra o mediador, que é o eleito para fazer a anuência do entendimento entre os envolvidos na adversidade. Uma relaçáo de desacordo entre a falta de conhecimento e entendimento gera conflitos, muitos deles oriundos dos preconceitos referentes aos movimentos sociais de gênero e dos negros. Nesse sentido, a busca para a solução 
dessa controvérsia passa pela autonomia e pela sensibilidade dos envolvidos, para que se possa chegar a uma pacificação. $\mathrm{O}$ mediador que enfrentará a diversidade deve ser uma pessoa que tenha a confiança das partes e a subjetividade do entendimento. Para Comarella,

[...] o mediador é o terceiro facilitador, comprometido com a condução do diálogo entre os envolvidos para que estes componham a disputa, restaurando seus processos de comunicação, sem impor ou sugerir soluçóes, portanto, possui o desafio de manter o diálogo das partes com civilidade, até que elas possam chegar à soluçấo do seu impasse. Antes de chegar o momento de início das negociaçôes, muitas vezes, será necessário ao mediador auxiliar as partes para que estejam preparadas para a negociação produtiva (COMARELLA, 2018, p. 152).

Luís Alberto Warat utiliza a mediação da Terapia do Reencontro Mediado (TRM), que aborda com ênfase os conflitos e a compreensão própria de si e do outro (outridade) visando ao amor e à sensibilidade. Segundo o autor, as intervenções mediadoras são de suma importância para serem trabalhadas em "espaços micro-organizacionais" (WARAT, 1999, p. 55), onde pondera a fome, o desejo de transformação, a exclusão, a falta de políticas públicas e, também, a cultura para a paz. Bertaso e Prado salientam que

[...] a mediaçáa busca estabelecer uma cultura de paz e, também, tornar mais forte a cultura político-democrática. Permite com que sejam resgatados os valores de uma nação enraizada a partir da democracia e auxilia na construção de uma sociedade mais justa, voltada para o respeito e para a tolerância. A mediação aparece, entâo, como uma forma de reencontro com o outro (BERTASO; PRADO, 2017, p. 55).

$\mathrm{Na}$ mediação, é necessário que haja o diálogo. Ou seja, os atores em conflito precisam estar dispostos a buscar o entendimento pelo diálogo, filtrando as emoçôes e buscando a simplicidade como modo de viver e nesse sentido Habermas afirma que

[...] os sujeitos que agem comunicativamente, ao se entenderem uns com os outros no mundo, também se orientam por pretensôes e validez assertóricas e normativas. Por isso, nâo existe nenhuma forma de vida sociocultural que não esteja pelo menos implicitamente orientada para o prosseguimento do agir comunicativo com meios argumentativos (HABERMAS, 1989, p. 123). 
Significa dizer que, em uma sociedade, o que prevalece é a comunicação e os meios argumentativos empregados para a institucionalização do entendimento mútuo. Quando os envolvidos têm conhecimento da importância da mediação, a justiça realiza-se com mais agilidade, de maneira correta e eles lidam com a adversidade satisfatoriamente. Tal cenário facilita a conversação respeitosa e propicia uma atmosfera conjunta de ouvir e expor os pontos de vista. Assim sendo, tem-se uma sessão de mediação favorável a um grau de consenso e que gere um acordo entre os atores. Martins (2017, p. 252) afirma "o agir comunicativo tem como pano de fundo a busca consensual do acordo entre os sujeitos acerca de uma situação, sendo que a linguagem desempenha uma função importante por meio de interpretação".

$\mathrm{Na}$ mediação, não se pode esquecer do terceiro, denominado mediador, que apenas conduz e facilita a troca de ideias entre as partes, tendo como função evidenciar opiniôes coincidentes e insistir que a exposiçáo de ambos os lados seja uma constante. Ele atenta para que os atores envolvidos no conflito se coloquem na posição do outro e tentem compreender as razóes aludidas de maneira real e não aparente. Segundo Warat (2001, p. 37), "o mediador tem que ajudar as partes para que possam celebrar acordos de coração, promessas assinadas desde os sentimentos, sentidas e totais". Seu papel é ser o catalizador das sensibilidades, transformando o conflito em sentimentos de humanização com relação ao outro. Para Warat (2001, p. 46), a formação de um mediador passa pelo nosso interior, e

[...] vamos fundo em nosso mar, quanto mais fundo mais calmo o encontraremos. Fiquemos lá; deixamos de ser um discípulo e tornamo-nos mestre. Deixando o tumulto, as tensōes, tudo fica relaxado, sereno, e os conflitos desvanecem-se. Ficamos mediados, harmonizados. Essa é a meta a ser atingida na formação de um mediador por seu mestre. [...] o mestre pode ajudar para que descubramos a presença que aproxima (WARAT, 2001, p. 46).

O mediador deve pautar-se em estimular as partes para que se resolvam entre si de maneira objetiva e racional, na visão sensível dos fatos, para buscar um meio de auxiliá-las a ver o conflito e enxergar-se naquela situação, considerando suas necessidades e desligando-se das amarras e desavenças.

\section{A mediaçáo como resgate da cidadania}

A esfera pública é um espaço de discussão visto como estando fora do poder estatal. É importante salientar que existem possibilidades de participação. Com a falta de credibilidade das instituiçóes e a falta de continuidade administrativa, a 
população não confia na consistência das políticas e no seu alcance. Parafraseando Taylor (2000, p. 166), supóe-se que ela seja escutada por aqueles que ocupam o poder, mas que não é em si um exercício do poder, ao mesmo tempo que a opiniáo pública esteja desvinculada da questão partidária. Para Habermas, o poder domado pela razão e não a autoridade faz a lei.

Uma ordem social pode ser dividida por profundos conflitos; outras demandas podem se sobrepor às questóes sociais, apesar da organização da sociedade civil. $\mathrm{Na}$ mediação, propóe-se que o conflito seja dirimido pela racionalidade e intersubjetividade dos atores envolvidos nessa confluência de divergências sociais. A mediação implica o reconhecimento de que, efetivamente, existem possibilidades de participaçáo.

As buscas pela justiça e pela paz social estão atreladas às políticas públicas do Estado e aos movimentos da sociedade, cuja junção de esforços poderá contar com efetiva participação dos cidadãos. Em geral, enfatiza-se um processo de construção de possíveis relaçôes sociais mais justas, mesmo que sem alcançá-las plenamente se for considerada a vida em sociedade, recheada de interesses em conflito. As políticas de mediaçáo, entretanto, têm transformado o reconhecimento mútuo em direitos para a concretização do princípio da dignidade humana. Talvez a ênfase na dimensão da justiça náo seja a mais fundamental do processo, uma vez que Nobre e Barreira (2008, p. 147) asseveram que "[...] o objetivo principal da mediação de conflitos não é [...] fazer justiça, mas encontrar uma solução satisfatória para as partes, de modo a promover a reparaçáo moral ou material dos danos sofridos e a resolução ou administração mais duradoura dos conflitos".

A Constituição Federal de 1988 assegura, dentre outros princípios fundamentais, a cidadania; cidadania essa que só inclui o cidadão que vota. Mas exercer a cidadania é bem mais amplo que isso. Como salienta Warat (2001, p. 156), "ser cidadâo é ter voz, poder opinar e poder decidir por si mesmo". A cidadania faz parte do espaço público e Bertaso e Rocha (2017, p. 204) a definem como

[...] um potencial de poder político de intervir na realidade social, o qual decorre da participaçáo e do envolvimento, de todos e de cada um, no processo de co-organizador da sociedade. Constitui um direito/dever de partilhar as condiçóes de possibilidades para gerar ambientes humanizados, sustentáveis, político e socialmente.

A cidadania deve estar vinculada aos direitos humanos para que seja possível realizar a mediação como "cultura" e "prática cotidiana das pessoas. 
A ideia de cidadania hoje implica inclusão, interação e reconhecimento, e sinaliza para uma vida igualmente digna a todo o ser humano. Estamos diante de novas demandas políticas, sociais e culturais. Essas demandas afloram/desvelam exatamente a problemática que a sociedade está trazendo como um dos tantos aspectos que estão a desafiar nossa sensibilidade enquanto cidadãos e cidadãs (BERTASO; ROCHA, 2017, p. 204).

Em virtude da globalização, a cidadania não é mais nacional, mas sim de direitos e respeito à dignidade humana dos cidadãos. Passa por um processo de ressignificação de pertencimento e, trabalhando com as diferenças entre os atores, segundo Bertaso e Prado (2017) a cidadania passa por um processo de ressignificação, ou seja, sua compreensão se dá muito além do limite territorial estabelecido pelos estados nacionais.

A mediação como emancipação é o elo necessário para o diálogo e pertencimento dos cidadãos em adversidade. E segue Bertaso:

[...] penso que a cidadania, enquanto política de direitos humanos, tende a legitimar os cidadãos no direito de agir em defesa da vida e apostando numa sociedade que pode se sustentar em cuidados mútuos; há que se reconhecer o direito à diferença, considerando as culturas particulares - suas diversas dimensōes espaciais, temporais, local e global (BERTASO, 2008, p. 15).

A busca pela emancipação passa pelo resgate da cidadania e também pela mediaçáo como meio inerente de tratar os conflitos efetivamente, o diálogo contribui como espaço de consenso e entendimento do outro. Nestes termos, Habermas (2010) traz a compreensão a respeito dos direitos humanos como a condição da liberdade para um indivíduo consolidar-se um membro da sociedade. Para referir-se a sujeitos sociais, ou certa autonomia dos cidadãos, que participam da consolidação dos seus direitos, há que atentar igualmente nas possíveis restriçôes no gozo dos direitos e às açôes do Estado que poderão lhe impor penalidades. $\mathrm{O}$ autor complementa: "aqui, porém, não é possível nenhuma outra vontade a não ser a de todo o povo (uma vez que todos determinam sobre todos e, portanto, cada um determina sobre si mesmo): pois ninguém pode ser injusto consigo mesmo" (HABERMAS, 2010, p. 124). Tal visão dá espaço para a natureza conflitiva dos direitos, ou mesmo da solidariedade, da complementariedade e da concorrência entre os direitos compreendidos como capacidade de estabelecer relaçóes sociais.

Entretanto, a racionalidade comunicativa se estabelece como instrumento de consenso social da realidade. É necessário um espaço de construção do diálogo, 
no qual as diferenças sejam uniformizadas e que possibilite a construção de pontos de discussóes comuns. Assim, são trabalhados novos rumos de respeito e de solidariedade.

A comunidade abandonada pelo Estado tem a chance de ser reconhecida por si mesma, a partir do momento em que se encontra e passa a pleitear os próprios direitos, por meio de uma cultura de conversa e da solidariedade. Isso não tira a soberania do Estado, mas dá às pessoas o direito de exercer sua autonomia em comunidade; se está emancipando os ignorados sem, contudo, excluir o dever do Estado de prestar auxílio e promover a mediação nas comunidades.

Para Abers e Bulow (2011, p. 55), "nas últimas três décadas, os movimentos sociais têm sido compreendidos como uma forma de ação coletiva sustentada, a partir da qual os atores que compartilham identidades ou solidariedades enfrentam estruturas sociais ou práticas culturais dominantes". A questão torna-se muito mais social do que econômica na linha abissal de separação de classes. Para a sociedade de contrato e da igualdade jurídica, existe uma característica que delineia essa realidade e que reduz a força de trabalho a uma mercadoria como outra qualquer.

As pessoas e até os grupos sociais podem viver numa situação social problemática e adversa e, ao mesmo tempo, ter dela uma compreensão insuficiente ou mesmo equivocada (MARTINS, 2008). O empenho efetivo pelos direitos significa ter uma compreensão apropriada e até em certo sentido objetiva, o que é mais raro. Entretanto, alguns programas de políticas públicas fazem a implementação da interface de inclusáo e, ao mesmo tempo, de exclusão, porque somente alguns são beneficiados ou porque existem processos parciais ou de mitigação das contingências. Nesse sentido, é esclarecedora a reflexão sob a ótica dialética de Martins ao asseverar que

[...] não estamos em face de um novo dualismo, que nos proponha as falsas alternativas de excluídos ou incluídos. A sociedade que exclui é a mesma que inclui e integra, que cria formas também desumanas de participação, na medida em que delas faz condiçẫo de privilégios e não direitos $[. .$.$] exclusão não diz$ respeito apenas aos 'excluídos'. Esse é, certamente, o problema menor porque é mais visível. A exclusão é o sintoma grave de uma transformação social que vem rapidamente fazendo de todos os seres humanos seres descartáveis, reduzidos à condição de coisa, forma extrema de vivência da alienação e da coisificação da pessoa (MARTINS, 2008, p. 20).

Esse fenômeno, assim descrito, não difere da realidade relativa ao acesso à justiça como inclusão social. Isso porque quem tem conhecimento de seus direitos 
soma esforços ou os pleiteia junto à administração da justiça. Outros cidadáos desconhecem os caminhos que os conduziriam aos seus direitos; ou outros que, com medo de represália, injustiça e até mesmo por percepção de desqualificação para viabilizá-los, desistem. O direito de acesso à ordem jurídica justa encara um verdadeiro direito fundamental instrumental, uma vez que a sua inefetividade ocasiona a ausência dos demais direitos fundamentais e, ainda, a negaçáo do exercício da cidadania, ou seja, o direito a ter direitos.

Nas comunidades mais pobres, em virtude da falta de educação e conhecimento, reside também a dificuldade em se expressar, precursora de conflitos. A mediação é o tratamento do que não se fala, é o tratamento daquilo que se está sentindo. Refere Warat que, na mediação é preciso "trabalhar os não ditos" (2004, p. 67). A mediaçáo constitui uma nova cultura de respeito, de harmonia, de conhecimento, de diálogo e, principalmente, de solidariedade - um atributo das comunidades que necessita ser resgatada. A solidariedade anda de mãos dadas com a alteridade; somos solidários quando nos colocamos ao lado do outro para sentir o que o outro sente, compreendendo sua dor como se nossa fosse. Para Warat, essa cultura se propóe a um paradigma que

[...] ultrapassa a dimensão de resolução não adversarial de disputas jurídicas. Ela possui incidências que são ecologicamente exitosas, como a estratégia educativa, como a realização política da cidadania, dos direitos humanos e da democracia. [...] deve ser encarada como uma atitude geral diante da vida (WARAT, 2004, p. 66).

A mediação é um avanço para as classes mais baixas, pois representa uma cultura contra hegemonia. Para Boaventura de Souza Santos, o poder hegemônico global realiza seus interesses por meio da legislação e da atuação estatal, sendo que "a nova contratualização é um falso contrato" (1999, p. 11) que fortalece o grupo dominante em desfavor dos colonizados. A mediação, como terapia do reencontro amoroso, parte da ideia que

[...] os processos de amor e desamor se encontram na vida de toda pessoa; que os vínculos afetivos formam parte de sua socializaçăo e contribuem para o seu bem-estar, ou sua infelicidade no dia a dia, sendo um componente estrutural no desenrolar dos conflitos e na possibilidade de estabelecer com o outro uma diferença neles (SANTOS, 1999, p. 20).

O reconhecimento se dá por meio de movimentos sociais, ou seja, instituiçôes que lutam por seus direitos dentro do espaço público e visam às garantias do 
sujeito. A justiça é a maneira de pensar com o outro, não é uma virtude pessoal, mas o modo como as relaçóes humana são organizadas igualitariamente, preservando o direito do indivíduo.

Entretanto, para que isso ocorra, cabe destacar uma teoria de justiça que abranja além da distribuição de direitos e bens e examine os padróes institucionalizados de valoração cultural. Inclusive, cabe a consideração sobre o quanto esse padrão impede a paridade de participação na vida social.

Para tanto, a mediaçáo se mostra um movimento contra-hegemônico de emancipação da comunidade e dos indivíduos que nela residem, resgatando e fortalecendo seus valores e, com isso, os relacionamentos. Tais valores residem notadamente da alteridade e solidariedade, isto é, na capacidade de se colocar a par do outro e se sensibilizar com suas dificuldades e problemas, se propondo a ajudar pelos meios e formas possíveis. Estabelece um exercício de cidadania e democracia ao passo que constrói uma cultura de diálogo e de busca por soluçóes e tratamento dos conflitos pela sensibilidade, solidariedade e amor.

\section{Consideraçóes finais}

A mediação, como processo de compreensão intersubjetiva das representaçôes sociais, instituiu, dentro dessa modalidade, os conflitos sociais, as desigualdades e o agir comunicativo como meio de prática do diálogo entre os atores. Dessa maneira, considera-se que o grau de conflitividade representa a expressáo concreta da significação da busca por interesses materiais e simbólicos no contexto atual do desenvolvimento contraditório da sociedade brasileira. De certa maneira, o conflito ocorre por haver dificuldades de comunicação entre pessoas ou grupos, seja por desigualdades sociais, por discordância de ideias, por problemas de autoestima ou de confiança.

Sendo assim, para que seja possível construir um diálogo entre os atores, é necessária a presença de um terceiro, denominado mediador, que tenha o manejo da situaçáo e a articulação de conhecimentos para permitir que os envolvidos dialoguem e se coloquem um no lugar do outro, a fim de contemporizar e formalizar o acordo, trazendo assim alguma satisfação a ambas as partes. Essa construção se dá no processo de identidade entre a diferença e a igualdade dos atores.

Para construção desse diálogo, é necessário que as partes estejam dispostas a compreender a importância de estar disposto a participar do processo de elaboração desses conflitos para a transformação de emancipaçáo da adversidade em respeito ao outro e à cidadania.

Entretanto, a pergunta que orientou este artigo é: a mediação é um meio 
emancipatório e de resgate da cidadania? Nessa perspectiva, o agir comunicativo, ou seja, o diálogo, é fundamental e representa um novo método de trabalho e observação dos conflitos. Ocorrem mudanças e crescimento na nova maneira de ver a prática e a aplicabilidade dos direitos humanos como busca pela paz social. O diálogo proporciona a reconstrução dos laços destruídos e obstruídos, a partir da compreensão de cada um dos sujeitos, no momento em que eles entendem que são partes conflitantes e responsáveis por essa alteridade.

Então, o diálogo respeitoso é a base consensual de existência de uma sociedade mais justa e inclusiva, para a reflexão sobre o seu papel naquele conflito social. Consolida-se, assim, uma maior autonomia de ação e de exercício da democracia, que é a liberdade de expressão. Para que essa liberdade seja alcançada, são necessários a transformação e o reconhecimento dos direitos a fim de se concretizar a dignidade humana e a busca pela paz social.

\section{Referências}

ABERS, R.; BULOW, M. V. Movimentos sociais na teoria e na prática: como estudar o ativismo através da fronteira entre estado e sociedade? Sociologias, Porto Alegre, v. 13, n. 28, p. 52-84, dez. 2011.

ALCÂNTARA JÚNIOR, J. O. Georg Simmel e o conflito social. Caderno Pós Ciências Sociais, São Luís, v. 2, n. 3, p. 7-15, jan./jul. 2005.

ARENDT, H. A condição humana. Rio de Janeiro: Forense, 1997.

BAUMAN, Z. Modernidade líquida. São Paulo: Zahar, 2001.

BEDIN, G.; BEDIN, G.; FISCHER, R. Justiça e direitos humanos: a crise da jurisdição estatal e as novas formas de tratamento de conflitos. In: DEL'OLMO, F.; GIMENEZ, C.; CERVI, T. (orgs.). Direitos fundamentais e cidadania: a busca pela efetividade. São Paulo: Milenium, 2013. p. 15-31.

BERTASO, J. M. Os direitos humanos como política da cidadania. Revista Direitos Culturais, Santo Ângelo, v. 3, n. 5, dez. 2008. Disponível em: <http://srvapp2s.urisan.tche.br/seer/index.php/direitosculturais/article/view/59/42>. Acesso em: 30 set. 2019.

BERTASO, J. M.; PRADO, K. S. Aspectos da mediação comunitária, cidadania e democracia. Revista Novos Estudos Jurídicos, Itajaí, v. 22, n. 1, jan./abr. 2017. Disponível em: <https://siaiap32.univali.br/seer/index.php/nej/article/ view/10632/5969>. Acesso em: 26 fev. 2018. 
BERTASO, J. M.; CACENOTE, A. P. Mediação: aspectos culturais nas relaçôes familiares. In: BERTASO, J. M.; LOCATELLI, L. (orgs.). Diálogos e entendimento: Direito e multiculturalismo \& políticas públicas e resoluçôes de conflitos. Rio de Janeiro: GZ, 2012. p. 3-24.

BERTASO, J. M.; ROCHA, L. S. Olhar sistêmico sobre cidadania e diversidade cultural. Revista de Direito Público, Porto Alegre, v. 13, n. 75, p. 202-217, maio/ jun. 2017. Disponível em: <https://www.portaldeperiodicos.idp.edu.br/direitopublico/article/view/2840>. Acesso em: 26 fev. 2018.

BRANDT, L. M.; BRANDT, L. J. Política nacional de tratamento de conflito no poder judiciário: uma análise a partir da Resolução n. 125/10 do Conselho Nacional de Justiça. In: XII SEMINÁRIO NACIONAL DEMANDAS SOCIAIS E POLÍTICAS PÚBLICAS NA SOCIEDADE CONTEMPORÂNEA, 12., 2016, Santa Cruz do Sul. Anais [...]. Santa Cruz do Sul: UNISC, 2016. Disponível em: <https:/online.unisc.br/acadnet/anais/index.php/snpp/article/ view/14609/3320>. Acesso em: 3 out. 2019.

CATTANI, A. D. Desigualdades socioeconômicas: conceitos e problemas de pesquisa. Sociologias, Porto Alegre, v. 9, n. 18, p. 74-99, jul./dez. 2007.

CINTRA, A. C. A.; GRINOVER, A. P.; DINAMARCO, C. R. Teoria geral do processo. São Paulo: Malheiros, 2010.

COMARELLA, D. Negociação e comunicação não violenta na mediação de conflitos. In: LIPPMANN, M. S.; OLDONI, F. (orgs.). Um olhar para o conflito: diálogo entre mediação e constelação sistêmica. Jaraguá do Sul: Manuscritos, 2018.

HABERMAS, J. Consciência moral e agir aomunicativo. Rio de Janeiro: Tempo Brasileiro, 1989.

HABERMAS, J. Direito e democracia: entre facticidade e validade. 2. ed. Rio de Janeiro: Tempo Brasileiro, 2010.

HELLINGER, B. Conflito e paz: uma resposta. São Paulo: Cultrix, 2019.

KRZNARIC, R. O poder da empatia: a arte de se colocar no lugar do outro para transformar o mundo. Rio de Janeiro: Zahar, 2019.

LAFER, C. A reconstrução dos direitos humanos: a contribuição de Hannah Arendt. Estudos Avançados, São Paulo, v. 11, n. 30, p. 55-65, 1997.

MARTINS, J. R. A mediação como política pública na gestão dos conflitos e o agir comunicativo como compreensão para o entendimento. In: STURZA, J.; 
LEVES, A.; BARRIQUELLO, C. (orgs.). Direitos humanos e conexöes com o futuro: um debate sobre direito, cidadania e políticas públicas. Porto Alegre: Evangraf/ Criação Humana, 2017. p. 237-264.

MARTINS, J. S. A sociedade vista do abismo: novos estudos sobre exclusão, pobreza e classes sociais. Rio de Janeiro: Petrópolis, 2008.

MULLER, J. M. Não violência na educação. São Paulo: Atlas, 2006.

MURILLO, S. Produção de pobreza e construção de subjetividade. In: CIMADAMORE, A. D.; CATTANI, A. D. (eds.). Produção de pobreza e desigualdade na América Latina. Porto Alegre: Tomo, 2007. p. 39-78.

MUNIZ, T. L. A ética na mediação. In: CASSELLA, P. B.; SOUZA, L. M. Mediação de conflitos: novo paradigma de acesso à justiça. Belo Horizonte: Fórum, 2009.

NOBRE, M. T.; BARREIRA, C. Controle social e mediação de conflitos: as delegacias da mulher e a violência doméstica. Sociologias, Porto Alegre, v. 10, n. 20, p. 138-163, 2008.

NOGUEIRA, M. A. Democracia, activismo y modernidad radicalizada en América Latina. Polis, Santiago, v. 13, n. 37, p. 457-472, 2014.

OLIVEIRA, M. B. Justiças do diálogo: uma análise da mediação extrajudicial e da produção de justiça. Dilemas: Revista de Estudos de Conflito e Controle Social, Rio de Janeiro, v. 4, p. 191-228, 2011.

ROSENBERG, M. A linguagem da paz em um mundo de conflitos. São Paulo: Palas Athena, 2019.

SANTOS, B. S. Pela mão de Alice. São Paulo: Cultura, 1999.

SOUZA, J. A gramática social da desigualdade brasileira. Revista Brasileira de Ciências Sociais, São Paulo, v. 19, n. 54, p. 79-97, 2004.

STRECK, L. L. Hermenêutica jurídica e $(m)$ crise: uma exploração hermenêutica da construçáo do Direito. Porto Alegre: Livraria do Advogado, 1999.

TAYLOR, C. Argumentos filosóficos. São Paulo: Loyola, 2000.

THERBORN, G. Os campos de extermínio da desigualdade. Novos estudos - CEBRAP, São Paulo, n. 87, p. 145-156, 2010.

TOURAINE, A. Crítica à modernidade. Petrópolis: Vozes, 1989. 
WARAT, L. A. O ofício do mediador. v. I. Florianópolis: Fundação Boiteux, 2001. WARAT, L. A. Surfando na Pororoca: ofício do mediador. v. III. Florianópolis: Fundação Boiteux, 2004.

WARAT, L. A. Em nome do acordo. Buenos Aires: Alamed, 1999. 


\title{
ANÁLISE JURISPRUDENCIAL: A TRIBUTAÇÃO DO DIREITO DE IMAGEM DO ATLETA PROFISSIONAL DE FUTEBOL
}

\author{
Leandro Miotto Mendes ${ }^{1}$ \\ 1 a Vara do Trabalho de Catanduva (SP) \\ Artigo recebido em: 12/09/2019. \\ Artigo aceito em: 02/10/2019.
}

\section{Resumo}

O presente trabalho visa discutir a jurisprudência sobre a tributação do direito de imagem na atividade dos atletas profissionais de futebol, no qual serão apresentados conceitos, natureza jurídica, autonomia e limitaçôes inerentes ao direito de imagem. Serão ainda apresentadas as modalidades contratuais, tanto no que se refere aos contratos realizados entre o atleta e seus patrocinadores, quanto aos realizados com os clubes de futebol, além de se analisar a empresa administradora do direito de imagem e a validade da ces- são do direito para tais empresas. Por fim, serão apresentadas suas formas de tributação tanto no Imposto de Renda Pessoa Física (IRPF) como na Tributação de Renda da Pessoa Jurídica (IRPJ, CSLL, PIS, COFINS e ISS), comparando tais tributações e analisando o posicionamento jurisprudencial a respeito.

Palavras-chave: aspectos tributários; atleta profissional de futebol; direito de imagem.

\section{JURISPRUDENCE ANALYSIS: TAXATION OF THE IMAGE IGHT OF THE PROFESSIONAL SOCCER ATHLETE}

\section{Abstract}

The present work aims to discuss the jurisprudence on the taxation of image right in the activity of professional soccer athletes, in which concepts, legal nature, autonomy and inherent limitations of the image right will be presented. The contractual modalities will also be presented, both with regard to the contracts made

1 Especialista em Auditoria e Perícia Contábil pelo Centro Universitário de Rio Preto (UNIRP). Cursando especialização em Direito Tributário pela Universidade Paulista (UNIP). Graduado em Direito pelo Instituto Municipal de Bebedouro "Victório Cardassi" (IMESB). Graduado em Ciências Contábeis pela Associação de Educação e Cultura do Norte Paulista (UNIFAFIBE). ORCID: https://orcid.org/0000-0001-9297-8169 / e-mail: leandromiottomendes@hotmail.com 
between the athlete and his sponsors, as well as with the football clubs, in addition to analyzing the company administering the image right and the validity of the assignment of the right for such companies. Finally, their forms of taxation will be presented both in Personal Inco- me Tax (IRPF) and in Corporate Income Tax (IRPJ, CSLL, PIS, COFINS e ISS), comparing such taxes and analyzing the jurisprudential positioning in this regard.

Keywords: image rights; professional soccer player; tax aspects.

\section{Introdução}

O futebol é, indiscutivelmente, o mais popular dos esportes praticados no mundo. Apesar de historiadores afirmarem que há séculos já havia esportes praticados com os pés e a bola, o futebol conhecido atualmente tem suas origens vinculadas à Inglaterra em meados do século XIX. Com o passar dos anos, foram surgindo institutos jurídicos com o objetivo de regulamentar a remuneraçáo dos jogadores de futebol. Além dos salários, que são inerentes a todos os trabalhadores, surgiram outras maneiras de remunerar os atletas, algumas popularmente conhecidas como "luvas", "bichos" e outras regulamentadas por normas jurídicas, como é o caso do direito de arena e do direito de imagem.

Com o advento da Lei n. 9.615, de 24 de março de 1998, conhecida como Lei Pelé, o direito de imagem foi inserido no ordenamento jurídico brasileiro, porém, ainda nos dias atuais existem discussões a respeito de tal instituto jurídico, principalmente no que se refere a sua tributação. Muito já foi debatido, nos tribunais, sobre a validade do contrato de cessão de imagem do atleta profissional de futebol. Diversos atletas já ingressaram com açôes trabalhistas contra seus respectivos clubes, alegando que o contrato efetuado seria um meio de burlar as legislaçóes trabalhistas. Há aplicadores do direito e órgãos com competência administrativa que entendem alguns contratos de cessão de imagem uma maneira de se esquivar da tributação aplicável.

Há, entâo, as seguintes dúvidas: qual é a natureza jurídica do direito de imagem? O contrato de cessão ou licenciamento do uso de direito de imagem pode ser considerado válido? Qual é a tributação a ser aplicada nos contratos de cessão ou licenciamento do uso de direito de imagem? A tributação do contrato de imagem deverá ser realizada pelo IRPF ou poderá ser realizada pelos tributos inerentes à pessoa jurídica?

As discussóes acerca da validade e dos aspectos tributários referentes ao contrato de imagem dos atletas de futebol estão em foco não somente no ordenamento jurídico interno, mas também no Direito Internacional, pois a discussão 
envolve esportistas brasileiros e estrangeiros de diferentes países, onde os atletas profissionais prestam seus serviços e realizam essa modalidade contratual. Por isso, é importante discutir as relaçôes contratuais existentes, haja vista que tais problemas envolvem as partes do contrato e também a sociedade, sendo o Estado e a coletividade diretamente interessados nas questôes tributárias geradas por tal negócio jurídico.

Portanto, o presente estudo terá por objetivo analisar a jurisprudência acerca da tributação do direito de imagem, especificamente na atividade dos atletas profissionais de futebol. No desenvolvimento serão apresentados os conceitos inerentes ao direito de imagem e sua validade, além de apresentar e comparar os modos de tributação na pessoa física e na pessoa jurídica.

Por fim, as metodologias a serem utilizadas para atingir tais objetivos serão o método histórico, que visa reconstruir o passado por meio de uma hipótese sustentável; o método comparativo, que propóe comparar dados concretos anteriores e aplicá-los ao caso, e o método dogmático jurídico, que pretende aplicar análises jurídicas e jurisprudenciais ao caso em estudo.

\section{Direito de imagem \\ 2.1 Conceito}

Conceituar o direito de imagem não é uma tarefa simples, uma vez que sua definição tem sofrido constantes atualizaçóes, principalmente com relaçáo à aplicabilidade no direito desportivo. Por esse motivo, para se entender os conceitos inerentes ao tema deste trabalho deve-se, primeiramente, compreender as relaçóes entre o atleta e o empregador e, em especial, os métodos de remuneração decorrentes desse vínculo.

Os principais rendimentos percebidos pelos profissionais de futebol são: (i) salário, decorrente de um contrato de trabalho; (ii) prêmio pelo resultado do jogo (bicho); (iii) participação na receita advinda do "direito de arena" pago por um terceiro que transmite o evento esportivo; e, ainda, (iv) valor pelo uso ou exploração da sua imagem (SILVA, 2009, p. 58). Esse último tipo de remuneração será o objeto de estudo do presente artigo.

A Constituição Federal $(\mathrm{CF} / 88)$ conferiu proteção à imagem, incluindo-a no rol dos direitos e garantias fundamentais (CF, art. 5º, V, X e XXVIII), o que demonstra a intenção do poder constituinte em dar-lhe máxima proteção, pois os direitos fundamentais devem e são reconhecidos como normas positivas constitucionais (princípios e/ou regras) com inquestionável caráter vinculante (NOVELINO, 2014). Além das previsóes constitucionais, alguns conceitos encontrados 
na Lei Pelé são de extrema importância para o desenvolvimento deste estudo, por exemplo, a natureza civil e a limitação de $40 \%$ do direito de imagem com relação à remuneração total paga ao atleta, que assim estão dispostos no art. 87-A:

O direito ao uso da imagem do atleta pode ser por ele cedido ou explorado, mediante ajuste contratual de natureza civil e com fixação de direitos, deveres e condições inconfundíveis com o contrato especial de trabalho desportivo.

Parágrafo Único. Quando houver, por parte do atleta, a cessão de direitos ao uso de sua imagem para a entidade de prática desportiva detentora do contrato especial de trabalho desportivo, o valor correspondente ao uso da imagem não poderá ultrapassar $40 \%$ (quarenta por cento) da remuneração total paga ao atleta, composta pela soma do salário e dos valores pagos pelo direito ao uso da imagem.

A retribuição econômica pelo uso da imagem poderá ser licenciada: (i) pelo próprio atleta; (ii) por uma empresa que detém o direito de explorar a imagem do esportista, com o qual celebrou contrato para esse fim e que lhe confere esse direito; ou (iii) por uma empresa, de cujo quadro de sócios participa o próprio desportista - e aqui reside a diferença entre o item "ii" -, e que detém o direito de explorar a imagem deste, de acordo com respectivo contrato firmado (SILVA, 2009). A maneira como o citado negócio jurídico será celebrado é de extrema importância para o desenvolvimento deste estudo, pois é por meio dessa celebração que será determinada o método de tributação em cada contrato.

\subsection{Natureza jurídica}

$\mathrm{O}$ art. 87-A da Lei Pelé define o direito ao uso da imagem de um atleta profissional como um ajuste contratual de natureza civil, definição que recebeu críticas por parte de doutrinadores, pois, segundo eles, não é a lei que deve definir a natureza de um determinado instituto jurídico, pois de nada adiantará a afirmação legal supra quando estivermos diante de um contrato de cessão do uso de imagem, em que, após análise detida da realidade, conclua-se que o pacto civil foi celebrado com o intuito de fraudar a lei, aplicando-se o princípio da primazia da realidade. Esquece o legislador que quem atribui natureza jurídica aos institutos é o direito e não a lei (ZAINAGHI, 2015).

$\mathrm{O}$ direito à própria imagem integra o rol dos direitos da personalidade, que são certas prerrogativas individuais, inerentes à pessoa humana, que aos poucos foram reconhecidas pela doutrina e pelo ordenamento jurídico, bem como 
protegidas pela jurisprudência. São direitos inalienáveis, que se encontram fora do comércio e que merecem a proteção legal (GONÇALVES, 2014). É exatamente pelo fato de a doutrina acreditar que os direitos da personalidade são inalienáveis que os doutrinadores do assunto acreditam ser mais adequado usar a terminologia "cessão do uso da imagem" ou "licenciamento de uso da imagem". E o presente estudo irá comumente utilizar esta primeira nomenclatura, haja vista ser a mais empregada pela doutrina e pela jurisprudência.

Por ser um direito personalíssimo e, portanto, inalienável, existiram intermináveis discussões acerca da validade dos contratos de cessão do uso de imagem. As questôes relativas à inalienabilidade do direito de imagem serão discutidas mais amplamente no tópico "limitaçôes", que abordará os limites de utilização da imagem por parte do clube e da empresa administradora do direito de imagem.

\subsection{Autonomia}

Historicamente sempre houve controvérsia a respeito da autonomia do direito à imagem, ou seja, sempre se discutiu se a imagem seria um bem jurídico que merecesse tutela protetiva autônoma no ordenamento jurídico brasileiro. Nesse sentido:

A autonomia do direito à imagem não é, e nem nunca foi, acolhida pacificamente. Alguns estudiosos compreenderam a imagem como expressão da identidade (Ritchel, Pontes de Miranda), outros como manifestação do direito ao próprio corpo (Carnelutti, Degni, Campogrande, Gareis). Muitos a inserem no campo da intimidade (De Culpis, Willian Prosser), teoria acolhida pelo sistema norte-americano por meio do instituto right of privacy; na seara do direito à honra (Alfredo Orgaz, Rosmini, Ferrara, Cohn, Pacchioni, Venzi, Vaunois) e na do direito autoral (Savatier, Gouriou, Newton Paulo Teixeira dos Santos). Houve, ainda, quem sustentasse que a imagem encontrava albergue no direito à liberdade (Giorgio Del Vecchio e Osterreith) e no patrimônio moral (Giltrana Gonzales e Quintana) (MORAES apud LOUREIRO, 2005, p. 99-100).

Fato incontroverso é que, assim como a maioria dos bens jurídicos, o direito à imagem também tem relação com outros institutos e ramos do direito, dentre os quais preponderantemente destacam-se os direitos constitucional, civil, trabalhista e tributário. É por isso, inclusive, que é possível afirmar que alguns institutos jurídicos que já eram tutelados pelo ordenamento jurídico nacional deram origem à proteção da imagem. 
O direito à honra, por exemplo, apesar de ser diferente, é um dos institutos que deram origem ao direito à imagem; outro bem jurídico diretamente ligado é o direito à intimidade e à privacidade, assim como os direitos autorais, dentre outros direitos que podem ser citados como exemplo de proximidade com o direito à imagem.

Por fim, as discussóes relativas à autonomia do direito à imagem terminaram por meio da CF, que conferiu proteção jurídica autônoma ao direito à imagem, inclusive quando relativa às práticas desportivas. Portanto, apesar de ainda muito confundida com outros institutos jurídicos, a doutrina majoritária reconhece, nos dias atuais, que a proteção à imagem é um instituto autônomo do direito, e que por isso merece ser tutelada de maneira diferenciada dos demais institutos com a qual é comumente confundida.

\subsection{Limitaçóes}

No momento em que se celebra um contrato em que o atleta faz a cessão do uso de sua imagem, não significa que o profissional está abrindo mão de sua imagem e, assim, permitindo que um terceiro a utilize de maneira ilimitada, sem seu consentimento. A imagem do indivíduo tem proteção penal, civil e constitucional, e não é pela celebração de um contrato que uma pessoa irá abrir mão de tal direito personalíssimo. No Código Civil (CC), o art. 20 trata da proibição da utilização da imagem do indivíduo, in verbis:

Salvo se autorizadas, ou se necessárias à administração da justiça ou à manutenção da ordem pública, a divulgação de escritos, a transmissão da palavra, ou a publicaçáo, a exposição ou a utilização da imagem de uma pessoa poderão ser proibidas, a seu requerimento e sem prejuízo da indenização que couber, se lhe atingirem a honra, a boa fama ou a respeitabilidade, ou se se destinarem a fins comerciais.

A expressão "salvo se autorizadas", contida no artigo acima transcrito, não significa que, quando o contrato é celebrado, o clube de futebol, ou qualquer outra pessoa física ou jurídica que adquirir o direito ao uso da imagem poderá fazer o uso absoluto da imagem do atleta, pois seria incabível admitir que um terceiro possa utilizar a imagem de determinada pessoa para expô-la ao ridículo ou causar prejuízos em sua vida particular.

Outra limitação importante é quanto ao valor a ser estipulado no contrato de cessão de uso da imagem. Em muitas ocasióes essa modalidade contratual foi 
utilizada para fraudar a legislação trabalhista, pois "os clubes muitas vezes de forma equivocada celebram contrato de cessão de uso de imagem com todos os atletas, mas como forma de se burlar a legislação trabalhista, e é nesse ponto que reside o grande problema" (ZAINAGHI, 2015, p. 68).

Finalmente, com as alteraçôes da Lei Pelé, as discussōes em torno da limitação econômica do direito de imagem foram pacificadas com a inclusão do parágrafo único do art. 87-A, já citado anteriormente. Ou seja, a partir dessa alteração na legislação, as associaçóes esportivas, além de respeitarem a honra e os bons costumes ao utilizar a imagem do jogador, devem celebrar tal negócio jurídico de natureza civil nesse proceso, considerando a limitação de $40 \%$ da remuneração total a ser paga ao atleta profissional do futebol.

\section{Contratos de cessáo do direito à imagem 3.1 Contratos entre patrocinadores e atletas}

O contrato é a mais comum dentre as fontes de obrigação, em razão de suas múltiplas configuraçôes e inúmeras repercussôes no mundo jurídico (GONÇALVES, 2015). Nesse sentido, é comum a celebração de contratos entre associaçôes desportivas, patrocinadores e outras pessoas jurídicas com atletas profissionais, os quais implicam obrigaçóes que podem repercutir em outras áreas do mundo jurídico, dentre elas o direito tributário, pois, nos termos do art. 110 do Código Tributário Nacional (CTN), o direito tributário é um direito de sobreposição, ou seja, atua sob o esteio de outras normas jurídicas (ARAUJO, 2007).

A imagem de um atleta quando vinculada a um produto ou serviço pode aumentar consideravelmente as vendas desse segmento. Assim como os clubes têm interesse em utilizar a imagem do atleta para vender seus produtos e de seus patrocinadores, outras empresas não vinculadas à associação esportiva também podem - e muitas vezes querem - associar a sua imagem à do atleta profissional. Há muito tempo as empresas perceberam que a imagem do atleta profissional, quando devidamente explorada, é uma ótima maneira de aumentar a visibilidade de suas marcas, produtos ou serviços e, consequentemente, expandir suas receitas.

É importante salientar que pode haver casos em que o contrato celebrado entre clube e o atleta profissional com a finalidade de explorar a imagem deste último poderá conter cláusulas que proíbam a celebração de contratos com terceiros, principalmente em casos em que a associação da imagem do atleta com determinada marca seja prejudicial aos interesses do clube ou possam gerar um conflito de interesse. Tais cláusulas deverão ser expressas, pois nos negócios jurídicos existem interesses diversos e, uma fornecedora de material esportivo de um 
clube, por exemplo, muitas vezes pode ser concorrente da marca que patrocina o atleta, o que não poderá ser proibido se no contrato do profissional com o clube não constar expressamente essa vedaçáo.

Feitas essas ponderaçôes, portanto, não há nada que impeça o atleta profissional de futebol de celebrar contratos com terceiros, com a finalidade de licenciar (ou ceder) a sua imagem para que seja associada a um determinado produto, marca ou serviço. Se não houver cláusula de exclusividade nem conflito de interesses, o atleta pode ceder sua imagem inúmeras vezes e para diferentes pessoas. Há ainda de se acrescentar que a sobredita cessão poderá, inclusive, ser gratuita, pois não há nada que impeça que o atleta vincule sua imagem sem que receba uma contraprestação econômica.

É importante registrar que tal modalidade contratual é de natureza civil e, dificilmente, há na doutrina e na jurisprudência discussões acerca de sua natureza, principalmente pelo fato de um dos requisitos básicos da legislação trabalhista ser a não eventualidade dos serviços prestados. Apesar de haver poucas discussôes sobre a possibilidade de se considerar o negócio celebrado com patrocinadores como uma espécie de contrato trabalhista, muitas discussôes existem com relação ao método de tributar tais contratos.

Originariamente, os contratos de cessão do uso de imagem eram tributados pelo IRPF. No decorrer dos anos, os atletas profissionais começaram a ser sócios de empresas cujo principal ativo era sua própria imagem, de modo que a exploração da imagem do atleta profissional passou a ser negociada por sua empresa. Isso fez que os contratos passassem, obrigatoriamente, a ser tributados pela pessoa jurídica e sujeitos aos tributos de pessoa jurídica. É nesse ponto que está a discussão central deste estudo, no qual serão expostas as divergências acerca da validade ou não dessa tributação pela empresa interposta.

\subsection{Contratos entre clubes e atletas}

Como visto anteriormente, ao celebrar um contrato com determinado clube de futebol, o atleta profissional, além de realizar um contrato de natureza trabalhista, poderá realizar contratos de natureza civil com a agremiação em que irá atuar, que são os denominados contratos de cessão ou licenciamento de uso da imagem do atleta profissional, pois, "uma coisa é receber salários para jogar futebol, outra é receber pela cessão do uso da imagem” (ZAINAGHI, 2015, p. 68).

Apesar de já ter sido tema muito controverso, hoje já está pacificado o entendimento de que o contrato entre clube e atleta, quando realizado conforme a lei, é de natureza civil. Contudo, o contrato de natureza civil celebrado para a cessão ou 
licenciamento do direito de imagem e realizado entre o clube e o atleta muitas vezes é utilizado de maneira irregular pelos clubes de futebol, sendo utilizado como artifício para burlar a legislação trabalhista.

Superadas as discussóes acerca da natureza jurídica do contrato de cessão de uso do direito de imagem, e partindo do pressuposto que o contrato não foi utilizado para fraudar as leis trabalhistas e é de natureza civil, novamente encontram-se as discussóes acerca da maneira a ser levado à tributação o contrato de direito de imagem. Assim como nos contratos diretos entre patrocinadores e atletas, no contrato civil celebrado entre clube e atleta também existe a possibilidade de tributação diretamente pela pessoa física do atleta ou por meio de uma empresa, sendo dela o atleta participante do quadro societário ou náo.

Diferentemente dos contratos realizados entre atletas e patrocinadores, que poderão ser firmados com empresas diferentes das associadas ao clube, o contrato de cessão do uso de direito de imagem entre o profissional e a associação esportiva está diretamente ligado ao contrato trabalhista, já que não poderá o atleta jogar por um clube e ceder sua imagem para outro, diverso daquele em que mantém seu vínculo empregatício. Ou seja, o contrato de cessão da imagem realizado entre o atleta profissional e o clube de futebol está diretamente ligado ao de natureza trabalhista, o que pode gerar equívocos entre as partes, na doutrina e na jurisprudência. Apesar disso, tais contratos deverão ser separados, sendo possível, inclusive, que um atleta náo possua contrato de cessão ou licenciamento do uso de imagem, mas apenas um contrato trabalhista com o clube de futebol.

\subsection{Empresa administradora de imagem}

Tradicionalmente, as empresas são aquelas que produzem bens e serviços que as pessoas necessitam ou desejam para viver (isto é, vestir, alimentar-se, dormir, divertir-se, etc.) e que são produzidos em organizaçóes econômicas especializadas (COELHO, 2015). As empresas começaram a ganhar importância com o desenvolvimento do comércio e da sociedade, e a atividade empresarial não ficou restrita aos atos do comércio.

$\mathrm{Na}$ lista dos atos de comércio não se encontravam algumas atividades econômicas que, com o tempo, passaram a ganhar importância equivalente às de comércio, banco, seguro e indústria. É o caso da prestação de serviços, cuja relevância é diretamente proporcional ao processo de urbanização. Também da lista não constavam atividades econômicas ligadas à terra, como a negociação de imóveis, agricultura ou extrativismo (COELHO, 2015, p. 27). 
Ou seja, com o passar dos anos e o desenvolvimento da sociedade, várias outras atividades empresariais surgiram, e a atividade de cessão de uso de imagem de artistas e esportistas é uma delas, como pode ser observado no $\$ 5^{\circ}$ do art. 980-A do CC, in verbis:

\begin{abstract}
Poderá ser atribuída à empresa individual de responsabilidade limitada constituída para a prestação de serviços de qualquer natureza a remuneração decorrente da cessão de direitos patrimoniais de autor ou de imagem, nome, marca ou voz de que seja detentor o titular da pessoa jurídica, vinculados à atividade profissional.
\end{abstract}

Ainda, a atividade está prevista com a Classificação Nacional de Atividades Econômicas (CNAE) n. 7490-1/05, que inclui, em uma de suas descriçóes, a cessão de uso de imagem de artistas, esportistas, etc. Isso significa que esse tipo de empresa tem previsão legal para ser constituída e exercer suas atividades afins. No entanto, isso não quer dizer que o contrato de cessão de uso da imagem não pode ser considerado inválido, o que, aliás, dá margem para muita discussão na doutrina e na jurisprudência.

\title{
3.4 Validade da cessáo à empresa
}

Embora não seja uma novidade a cessão da imagem do atleta profissional para terceiros por meio de pessoa jurídica, muito ainda se discute na atualidade acerca da validade de tal procedimento. $\mathrm{O}$ tema ganhou destaque na mídia nacional, principalmente pelo fato de o jogador Neymar dos Santos Júnior, principal atleta de futebol do país em atividade, estar sendo acusado no Brasil pelas práticas de fraude e sonegação fiscal, exatamente em razão desse tipo de negócio jurídico (cessão de imagem para associação desportiva).

Além de Neymar e diversos outros profissionais do futebol, outro atleta profissional também está sendo acusado pela prática dos mesmos ilícitos: Gustavo Kuerten, o popular Guga, principal tenista da história do país. O "Caso Guga”, como ficou conhecido, foi julgado pelo Conselho Administrativo de Recursos Fiscais (CARF) em outubro de 2016 e trata da desconsideração da personalidade jurídica de empresa de cujo quadro societário o tenista faz parte, sob a alegação de que, na prática, era o próprio quem prestava os serviços de caráter personalíssimo, como pode ser observado na ementa do recurso:

CESSÃO DE DIREITOS DE IMAGEM. NATUREZA PERSONALÍSSIMA. TRIBUTAÇÃO NA PESSOA FÍSICA. 
Os rendimentos decorrentes de serviços de natureza eminentemente pessoal, inclusive os relativos a cessão de direitos de imagem, devem ser tributados na pessoa física do efetivo prestador do serviço, sendo irrelevante a denominação que lhes seja atribuída ou a criação de pessoa jurídica visando alterar a definição legal do sujeito passivo.

O assunto é polêmico e, por isso, tanto na doutrina como na jurisprudência podem ser encontradas opinióes divergentes. Recentemente o CARF julgou procedente o pedido do Fisco de desconsideração da personalidade jurídica no "Caso Guga”, contudo, a doutrina majoritária discorda, afirmando que:

[...] não é o fato de se constatar a existência de um serviço personalíssimo que, obrigatoriamente, a tributação há de ser declarada e apurada como pessoa física a título de imposto sobre a renda, pois: (i) - é preciso avaliar o caso concreto e as provas existentes com o objetivo de comprovar, efetivamente, a configuração de uma simulação, levando a uma sociedade aparente ou fictícia; (ii) - a existência de serviços personalíssimos não leva por si só à configuração de simulação; (iii) - é plenamente compatível a existência de pessoa jurídica cujo serviço ligado ao seu objeto social tenha natureza pessoal; (iv) - a participação pessoal dos sócios na execução do objeto social, quando se trata de uma prestadora de serviços é algo inerente e natural; (v) - a pessoalidade na prestação de serviços é totalmente reconhecida pela legislação do imposto sobre a renda e por outros tributos como possível de estar relacionada à uma pessoa jurídica; (vi) - quando se cuidar de pessoa jurídica prestadora de serviços de profissão regulamentada, mesmo no caso de serviço personalíssimo, poderá tributar tais receitas por aquela, desde que os sócios estejam em condiçôes de exercer referida atividade e contribuíam para o objeto social; (vii) - se houver uma pessoa jurídica com elementos de empresa, dentro da mesma perspectiva, a natureza de serviço personalíssimo não impede a tributação como pessoa jurídica (CALCINI, 2016, p. 4-5).

O Fisco, já há vários anos, tem autuado os contribuintes, aplicando-lhes multas e grandes juros, além de imputar-lhes crimes como de sonegação fiscal. O argumento principal do Fisco é que a execução dos chamados "serviços publicitários” é um direito personalíssimo da pessoa física, não havendo execução propriamente pela empresa sem a presença da estrela e que, consequentemente, 
a abertura da sociedade teve como único objetivo a redução da carga tributária incidente sobre tais rendimentos. O contribuinte, por sua vez, defende que a legislação e a jurisprudência civis e tributárias acolhem esse modelo de negócio e não poderia o Fisco pretender um deslocamento dos rendimentos da pessoa jurídica para a pessoa física, sem que invoque um fundamento especifico de dolo e fraude (NEDER, 2015, p. 3), e alegam principalmente, o conteúdo da Lei n. 11.196, de 21 de novembro de 2005, cujo art. 129 assim estabelece:

Para fins fiscais e previdenciários, a prestação de serviços intelectuais, inclusive os de natureza científica, artística ou cultural, em caráter personalíssimo ou não, com ou sem a designação de quaisquer obrigaçôes a sócios ou empregados da sociedade prestadora de serviços, quando por esta realizada, se sujeita tão-somente à legislação aplicável às pessoas jurídicas, sem prejuízo da observância do disposto no art. 50 da Lei n. 10.406, de 10 de janeiro de 2002 - Código Civil (BRASIL, 2005).

Enfim, o tema encontra muitas divergências e muitos se perguntam por que a discussão é tão importante e merece tanto destaque na mídia. $\mathrm{O}$ que realmente importa são as diferenças entre a tributação pela pessoa física ou pela pessoa jurídica, que seráo tratadas no próximo tópico, oportunidade em que serão demonstrados os cálculos em ambas as hipóteses, com a finalidade de demonstrar tais diferenças.

\section{Tributaçáo do contrato de direito à imagem 4.1 O Direito Tributário como um direito de sobreposição: o art. 110 do CTN}

O Direito Tributário é definido pelos doutrinadores como um direito de sobreposição, pois são "várias disciplinas, tratando os fenômenos por estas regidos em primeira linha, de acordo com seu espírito e exigências próprios: pode neste sentido dizer-se que o Direito Fiscal é um direito de sobreposiçáo" (XAVIER 1981 apud ESTRADA, 2013), ou seja, sua capacidade de atuação encontra-se definida nas demais normas do ordenamento jurídico. O art. 110 do CTN, por exemplo, assim está disposto:

A lei tributária não pode alterar a definição, o conteúdo e o alcance de institutos, conceitos e formas de direito privado, utilizados, expressa ou implicitamente, pela Constituiçâao Federal, pelas 
Constituiçôes dos Estados, ou pelas Leis Orgânicas do Distrito Federal ou dos Municípios, para definir ou limitar competências tributárias (BRASIL, 1966).

Seguindo tais premissas, poderia o Fisco alterar a receita declarada pela pessoa jurídica legalmente constituída para uma determinada pessoa física, ou seja, é legítimo o deslocamento de determinado fato gerador para outra pessoa pelo Direito Tributário?

Tal questionamento é de difícil resposta, pois tanto na doutrina quanto na jurisprudência existem opinióes divergentes a respeito. Na hipótese dos contratos de direito à imagem, o Judiciário deverá interpretar se a regra contida no art. 110 do CTN tem ou não aplicabilidade concreta no caso. Deverão os aplicadores do direito decidirem se pode o Direito Tributário alterar a natureza jurídica dos contratos de cessão de direito à imagem e, consequentemente, desfazer o negócio jurídico celebrado para deslocar a receita de uma pessoa jurídica para uma pessoa física.

\subsection{O imposto de renda da pessoa física}

A pessoa física deverá apurar seus resultados anualmente, em 31 de dezembro de cada ano-calendário, e também tem a obrigação de apresentar Declaração do Imposto Sobre a Renda da Pessoa Física (DIRPF) (JESUS, 2017) com o objetivo de apurar eventuais valores devidos ou a serem restituídos, observando-se as regras pertinentes. O contrato de cessão dos direitos de imagem do atleta profissional do futebol, quando realizado diretamente entre o clube e o atleta, será tributado pelo IRPF, ou seja, os valores recebidos a título de direito de imagem serão tributáveis pelo IRPF.

Depois de apurada a base de cálculo, o valor a ser pago a título de IRPF é apurado por intermédio da aplicação da tabela progressiva anual para o cálculo do imposto e, em seguida, desconta-se a parcela a deduzir do imposto determinada pela mesma lei que fixa as alíquotas, as quais podem variar de $7,5 \%$ a $27,5 \%$.

\subsection{Os tributos da pessoa jurídica}

As pessoas jurídicas são tributadas, basicamente, de três maneiras: por meio do Simples Nacional, do Lucro Presumido ou do Lucro Real. Tais modalidades tributárias têm diversas implicaçôes, portanto, podem variar para cada empresa. Determinadas empresas podem estar impedidas de optar por um dos regimes tributários, mas, caso não estejam, podem optar por qualquer regime. 
As empresas com a atividade de cessão de uso de imagens de artistas e esportistas podem optar pelo Simples Nacional, pelo Lucro Presumido e pelo Lucro Real. No Simples Nacional, a partir de 2018, serão tributadas pelo Anexo III ou V da Lei Complementar 123/2006, o que implica uma alíquota que pode variar de 6\% a 33\%. Já no Lucro Presumido, a alíquota final pode variar, principalmente por causa do ISS (Imposto sobre Serviços), mas geralmente a tributação gira em torno de $13,33 \%$. Por fim, o percentual final do Lucro Real será obrigatoriamente variável, já que a tributação é calculada pela apuração final do lucro, podendo variar de $0 \%$ até $33,25 \%$.

Apesar de a opção pelo regime tributário depender de inúmeras variáveis e de ser subjetiva a cada empresa, geralmente as empresas enquadradas na atividade de cessão de direito de imagens optam pelo regime do Lucro Presumido e para efeitos de comparação com o IRPF, será esse o regime a ser utilizado.

\subsection{Comparação}

A grande polêmica com relação à tributação dos contratos de cessão do direito de imagem dos atletas profissionais gira em torno da diferença a ser recolhida quando tributado pela pessoa física ou pela pessoa jurídica. A título de exemplo, será utilizado um caso em que a remuneração será de $\mathrm{R} \$$ 100.000,00 mensais, dos quais $40 \%$ serão pagos à título de direito de imagem.

Por meio do IRPF, tanto os valores pagos no contrato trabalhista, quanto os valores pagos a título de direito de imagem serão levados à tributação como valores tributáveis na declaração de ajuste anual, ou seja, serão somados e sua base de cálculo irá ser tributada do seguinte modo:

Tabela 1

\begin{tabular}{|c|c|}
\hline \multicolumn{2}{|c|}{ Cálculo Anual do IRPF } \\
\hline Rendimentos tributáveis & $1.200 .000,00$ \\
\hline (-) Deduções & $7.301,33$ \\
\hline Base de cálculo & $1.192 .698,67$ \\
\hline Alíquota aplicável & $27,50 \%$ \\
\hline Valor apurado & $327.992,00$ \\
\hline Parcela a deduzir & $10.432,32$ \\
\hline Imposto Devido & $317.559,81$ \\
\hline
\end{tabular}

Fonte: Brasil (2019). 
Caso o contrato de direito de imagem seja tributado pela pessoa jurídica, deverão ser realizados dois cálculos: um com os valores referentes ao contrato trabalhista, que será levado à tributação pela pessoa física, e outro a ser realizado com o contrato de cessão dos direitos de imagem, que seráo levados à tributaçáo pela pessoa jurídica:

Tabela 2

\begin{tabular}{|c|c|}
\hline \multicolumn{2}{|c|}{ Cálculo Anual do IRPF } \\
\hline Rendimentos tributáveis & $720.000,00$ \\
\hline (-) Deduções & $7.301,33$ \\
\hline Base de cálculo & $727.301,33$ \\
\hline Alíquota aplicável & $27,50 \%$ \\
\hline Valor apurado & $200.007,87$ \\
\hline Parcela a deduzir & $10.432,32$ \\
\hline Imposto devido & $189.575,55$ \\
\hline
\end{tabular}

Fonte: Brasil (2019).

\begin{tabular}{|c|c|c|c|c|c|}
\hline \multicolumn{7}{|c|}{ Cálculos Lucro Presumido } \\
\hline Imposto & Receita & Percentual & $\begin{array}{c}\text { Base de } \\
\text { cálculo }\end{array}$ & Alíquota & Imposto a pagar \\
\hline IRPJ & $480.000,00$ & $32 \%$ & $153.600,00$ & $15,00 \%$ & $23.040,00$ \\
\hline CSLL & $480.000,00$ & $32 \%$ & $153.600,00$ & $9,00 \%$ & $13.824,00$ \\
\hline COFINS & $480.000,00$ & $\mathrm{X}$ & $\mathrm{X}$ & $3,00 \%$ & $14.400,00$ \\
\hline PIS & $480.000,00$ & $\mathrm{X}$ & $\mathrm{X}$ & $0,65 \%$ & $3.120,00$ \\
\hline ISS & $480.000,00$ & $\mathrm{X}$ & $\mathrm{X}$ & $2,00 \%$ & $9.600,00$ \\
\hline \multicolumn{7}{|c|}{} & & Total & $63.984,00$ \\
\hline
\end{tabular}

Fonte: Brasil (2019).

Enfim, quando o contrato de cessão do direito de imagem for celebrado diretamente com a pessoa física do atleta, os valores a serem pagos a título de IRPF sáo de $\mathrm{R} \$ 317.559,81$. Por outro lado, quando o contrato for celebrado por uma pessoa jurídica interposta, os valores a serem pagos serão de $R \$ 253.559,55$, o que acarretaria uma diferença na tributação em $\mathrm{R} \$$ 64.000,26. 


\subsection{Análise crítica da jurisprudência a respeito do tema}

É por meio da jurisprudência que se pode verificar a tendência dos tribunais ao julgar um determinado caso. Como visto, a doutrina considera que o contrato efetuado diretamente entre o atleta e o patrocinador "ilicitamente", i.e., sem o intuito de fraudar a legislação trabalhista, e que é realizado entre o atleta e o clube com o intuito de cessão ou licenciamento do uso de imagem do atleta profissional, apresentam natureza civil. Porém, as discussóes e divergências jurisprudencial começam quando se discute de que modo tais contratos de natureza civil seráo levados à tributação pelas partes envolvidas.

Por um lado, os contribuintes desejam que os contratos possam ser livremente estipulados, podendo constituir empresas em que o cedente possa ou não ser participante do quadro societário com a finalidade de realizar contratos de cessão ou de licenciamento do uso de imagem. De outro lado, o Fisco geralmente entende que os contratos de cessão de uso de imagem devem ser levados à tributaçáo diretamente pela pessoa física do contribuinte. No tópico 3.3 deste estudo concluiu-se que a empresa administradora de imagens tem previsão para ser constituída e exercer suas atividades afins e, nesse ponto, o Fisco náo diverge dos contribuintes. Porém, para poder afirmar que a receita decorrente do contrato de cessão do uso de imagem realizado entre a pessoa jurídica e o clube ou patrocinador é indevido, o Fisco deve considerar inválida a operação realizada pela empresa.

Aqui, Fisco e contribuintes divergem, porque no entendimento do Fisco existe falta de propósito negocial em tais negócios jurídicos, que é o que os norte-americanos chamam business purpose - expressão com a qual designam o propósito ou a motivação que ordinariamente está presente porque enseja a atividade empresarial, é o propósito ligado aos objetivos visados pela empresa, ou de algum modo ligados à sua atuação no mercado. (MACHADO, 2014). Já na visão dos contribuintes, a alegada inexistência de propósito negocial gera a desconsideração da personalidade jurídica, prevista no art. 50 do CC, sendo pressuposto desta a ocorrência de fraude e que, segundo eles, tal fraude não pode ser afirmada pelo Fisco em âmbito administrativo. Isso é considerado porque o Fisco autua e aplica sançóes administrativamente e o instituto da desconsideração da personalidade jurídica supóe que tal decisão seja tomada pelo juízo.

Além da alegação da impossibilidade dessa desconsideração, os contribuintes alegam que a inexistência de propósito negocial afirmada pelo Fisco não tem previsão no ordenamento jurídico brasileiro, sendo tais conceitos oriundos de outros 
países, principalmente do ordenamento norte-americano.

Sobre o propósito negocial, Luís Flávio Neto, conselheiro do Conselho Administrativo de Recursos Fiscais (CARF), em seu voto em acórdão sobre a constituição de uma imobiliária, assim afirma:

[...] NÃO há lei que autorize a referida discriminação com base na aferição subjetiva de motivos extratributários ("propósitos negociais"). Apenas se poderia atribuir tratamento distinto entre contribuintes que se encontram semelhantes ("A" e "B") caso o legislador houvesse prescrito tal discrímen, com o delineamento do que viriam a ser esse conceito de "propósito negocial" até hoje não delineados e desconhecidos no Direito positivo brasileiro.

[...] Pode-se concluir, portanto, não ser possível afirmar que há no Brasil, o controle de planejamentos tributários fundado no critério do propósito negocial. Além de não haver norma expressa no ordenamento jurídico que o recepcione, a jurisprudência administrativa se mostra vacilante em sua aplicação, não sendo pacífica a sua adoção pelos julgadores do CARF. Conforme observa LUÍS EDUARDO SCHOUERI, ao analisar uma série de precedentes do antigo Conselho de Contribuintes, embora o questionamento do propósito negocial seja uma constante, é comum que tais decisôes também se fundamentem em teorias como o abuso de direito e a fraude à lei. "Evidentemente, o antigo Conselho de Contribuintes não se sentia à vontade para revelar que, em verdade, aplicava a doutrina desenvolvida no common law, não obstante a ausência de previsão legal” (NETO, 2011, p. 236).

Contudo, a jurisprudência recente tem dado razão ao Fisco, por exemplo, no já citado "Caso Guga”, em que o CARF entendeu que não houve desconsideração da personalidade jurídica e sim um deslocamento de receita, como pode ser observado no seguinte trecho do acórdão:

Partindo à análise das alegaçóes do Recorrente, impende salientar, de plano, que não houve, in casu, a alegada desconsideração da personalidade jurídica da empresa detentora dos direitos da marca, nome, imagem e voz do tenista profissional. Neste ponto, não lhe assiste razão, pois o que ocorreu nos presentes autos nâo foi verdadeira desconsideraçáo da personalidade jurídica; o que houve foi a transferência (ou deslocamento, como alguns preferem) dos rendimentos por ela recebidos para a pessoa física 
do Recorrente. Isto é, houve uma alteração no apontamento do verdadeiro beneficiário do rendimento (CARF, Acórdão n. 10617.147).

Apesar de o tema ser controverso, a jurisprudência geralmente tem dado razão ao fisco, e considerando que tal procedimento não é uma desconsideração da personalidade jurídica e sim apenas um deslocamento de receita, desconsiderando assim, entre outros argumentos, a validade do contrato de cessão de uso do direito de imagem realizado pelas pessoas jurídicas. É o que se pode perceber, no acórdão do "Caso Neymar" que, apesar de ainda continuar em andamento, até agora o entendimento do CARF, Acórdão n. 2402005.703 - 4a Câmara / 2a Turma Ordinária é de que:

Não houve desconsideração de pessoa jurídica, mas o reconhecimento pela fiscalização, com base na legislação em vigor, do verdadeiro sujeito passivo da obrigaçáo tributária, dada a revelação do esquema simulatório já narrado. Ineficaz a simulação perante o Fisco, por força de lei, a imputação dos fatos tributários ao real contribuinte surge como poder dever legal da administraçáo.

Porém, não se pode dizer que a tendência do CARF é entender pelo deslocamento da receita, pois em recente decisão, já há divergência, conforme a seguinte ementa:

DIREITO DE IMAGEM. ASPECTO PATRIMONIAL. POSSIBILIDADE DE CESSÃO.

O direito à imagem decorre do direito à personalidade, esse sim, intransmissível e irrenunciável. Já aquele, o direito de imagem, direito decorrente do direito de personalidade, pode - em seu aspecto positivo, patrimonial - ser transmitido, explorado por pessoa jurídica constituída para este fim.

Ou seja, a divergência continua dentro do próprio CARF, pois trata-se do julgamento de outro jogador famoso, "Dário Leonardo Conca", popularmente conhecido como "Dario Conca”, cujo entendimento dos julgadores discorda dos entendimentos do "Caso Guga" e do "Caso Neymar", e considerou válida a cessão dos direitos de imagem realizada pelo atleta a pessoa jurídica constituída para esse fim. 


\section{Consideraçóes finais}

Por meio do Código Civil, é fato notório que os requisitos de validade de um negócio jurídico, que estão contidos no art. 104, são: a capacidade das partes; que o objeto seja lícito, possível, determinado ou determinável; e que a forma seja prescrita ou não defesa em lei. Portanto, pode-se concluir que, caso sejam respeitados tais requisitos, a cessão de direito de uso de imagem não poderá ser considerada um negócio inválido.

Uma das alegaçóes do Fisco para justificar a transferência da tributação da pessoa jurídica para a pessoa física é que o contrato é realizado mediante fraude e com o único objetivo de fraudar os cofres públicos, inexistindo propósito negocial, o que não se justificaria, pois, sendo assim, todos os meios de planejamento tributário seriam ilegais, uma vez que todos têm a intenção, de dentro da legalidade, de diminuir a tributaçáo. Outro argumento das autoridades administrativas é que a cessão de imagem é um serviço personalíssimo e só poderia ser realizado pela pessoa física do atleta. Pois bem, ao realizar a cessão para que uma empresa administre sua imagem, existem inúmeras maneiras de exploração, seja por meio de imagens, sons e marcas vinculadas ao atleta e, não necessariamente, será indispensável a prestaçáo de serviços do atleta. A empresa poderá associar a marca ou nome do atleta de inúmeras maneiras e até mesmo ele poderá ter seu nome divulgado por empresas que nem mesmo conheça, haja visto que a cessão do uso da imagem permite à empresa utilizá-la da maneira que bem entender, desde que náo ofenda a dignidade moral do atleta.

Ainda com relação aos argumentos da natureza personalíssima, existiria um serviço mais vinculado à pessoa física do que um cirurgiáo que realiza um procedimento específico e que poucos realizam? Nem por isso o médico que possui um consultório é questionado para que tais receitas sejam declaradas como um serviço realizado pela pessoa física. Ainda neste sentido, o art. 129 da Lei n. 11.196/2005 dispóe que os serviços intelectuais, científicos, artísticos ou culturais, com ou sem designação de obrigaçôes a sócios ou empregados, se submetem as regras aplicáveis à pessoa jurídica para fins fiscais e previdenciários (BRASIL, 2005).

Enfim, apesar da discordância majoritária da doutrina, em esfera administrativa os órgãos responsáveis (Receita Federal, CARF, entre outros) têm decidido pelo deslocamento da receita inerente aos contratos de direito de imagem da pessoa jurídica para a pessoa física do atleta. Provavelmente tais discussóes percorrerão os tribunais nos próximos anos, até que cheguem ao Supremo Tribunal Federal (STF) e sejam decididas. Nessa situação, o "Caso Guga” e, principalmente, o "Caso Neymar" deveráo ser um divisório na jurisprudência, indicando pela 
validade ou não dos contratos de cessão ou uso do direito de imagem no ordenamento jurídico brasileiro.

\section{Referências}

ARAUJO, A. C. M. S. O artigo 110 do Código Tributário Nacional: alteração de conceitos e definições do sistema jurídico. Dissertação (Mestrado em Direito Tributário) - Pontifícia Universidade Católica, São Paulo, 2007.

BRASIL. Conselho Administrativo de Recursos Fiscais. Processo n. 11080.723307/2012-06. Recorrente: Transpinho Madeiras Ltda e Saiqui Empreendimentos Imobiliários Ltda. Interessada: Fazenda Nacional. Brasília, DF, 18 de agosto de 2016.

. Conselho Administrativo de Recursos Fiscais. Processo n. 15983.720065/2015-11. Recorrente: Neymar da Silva Santos Júnior. Recorrida: Fazenda Nacional. Relator: Bianca Felícia Rotschild. Brasília, DF, 15 de março de 2017a.

. Conselho Administrativo de Recursos Fiscais. Processo n. 18470.728514/201466. Recorrente: Dário Leonardo Conca. Recorrida: Fazenda Nacional. Relator: Carlos Alberto do Amaral Azeredo. Brasília, DF, 05 de julho de $2017 b$.

. Conselho Administrativo de Recursos Fiscais. Recurso n. 154.280. Recorrente: Gustavo Kuerten. Recorrida: $3^{a}$ Turma/DRJ-Florianópolis/SC. Relator: Giovanni Christian Nunes Campos. Brasília, DF, 18 de maio de 2010.

. Constituição (1988). Constituiçâao da República Federativa do Brasil: promulgada em 5 de outubro de 1988. Disponível em: <http://www.planalto.gov. br/ccivil_03/constituicao/constituicaocompilado.htm>. Acesso em: 26 dez. 2016.

. Lei n. 5.172, de 25 de outubro de 1966. Dispóe sobre o Sistema Tributário Nacional e institui normas gerais de direito tributário aplicáveis à União, Estados e Municípios. Disponível em: <http://www.planalto.gov.br/ccivil_03/leis/ L5172Compilado.htm>. Acesso em: 17 jul. 2017.

. Lei n. 9.615, de 24 de março de 1998. Normas gerais sobre desporto e dá outras providências. Disponível em: <http://www.planalto.gov.br/ccivil_03/leis/ L9615consol.htm>. Acesso em: 13 jul. 2016.

. Lei n. 10.406, de 10 de janeiro de 2002. Código Civil. Disponível em: $<$ http://www.planalto.gov.br/ccivil_03/leis/2002/110406.htm>. Acesso em: 26 dez. 2016. 
. Lei n. 11.196, de 21 de novembro de 2005. Regime Especial de Tributação para a Plataforma de Exportação de Serviços de Tecnologia da Informação - REPES, e dá outras providências. Disponível em: <http://www.planalto.gov.br/ ccivil_03/_ato2004-2006/2005/lei/111196.htm>. Acesso em: 27 ago. 2017.

. Receita Federal. Simulação de alíquota efetiva: exercício de 2019, ano-calendário de 2018. Brasília, DF, 2019. Disponível em: <http://www.receita. fazenda.gov.br/Aplicacoes/ATRJO/Simulador/simulador.asp?tipoSimulador=A>. Acesso em: 4 out. 2019.

CALCINI, F. P. Caso Guga e a desconsideração da personalidade jurídica para fins fiscais. Consultor Jurídico. Disponível em: <http://www.conjur.com.br/ 2016-nov-01/fabio-calcini-guga-desconsideracao-pessoa-juridica>. Acesso em: 2 dez. 2016.

CASSAR, V. B. Direito do trabalho. 11 ed. rev. e atual. Rio de Janeiro: Forense, São Paulo: Método, 2015.

COELHO, F. U. Manual de direito comercial. 27 ed. São Paulo: Saraiva, 2015.

ESTRADA, R. D. Princípio da realização e justa medida da tributação. Consultor Jurídico. Disponível em: <http://www.conjur.com.br/2013-jan-23/consultor-tributario-principio-realizacao-justa-medida-tributacao>. Acesso em: 26 fev. 2017.

GONÇALVES, C. R. Direito civil brasileiro: parte geral. 12 ed. São Paulo: Saraiva, 2014. V. 1.

GONÇALVES, C. R. Direito civil brasileiro: contratos e atos unilaterais. 12 ed. São Paulo: Saraiva, 2015. V. 3.

JESUS, F. B.; JESUS, I. B.; JESUS, R. B. Manual de direito e processo tributário. 4. ed. São Paulo: Revista dos Tribunais, 2017.

LOUREIRO, H. V. Direito à imagem. 2005. 198 p. Dissertaçáo (Mestrado em Direito das Relaçóes Sociais) - Pontifícia Universidade Católica de São Paulo, São Paulo, 2005.

MACHADO, H. B. Introdução ao planejamento tributário. São Paulo: Malheiros, 2014.

NEDER, M. A evolução legislativa e jurisprudencial da tributação do direito de imagem de artistas e atletas. JOTA, 5 out. 2015. Disponível em: <https://www. jota.info/opiniao-e-analise/artigos/a-evolucao-legislativa-e-jurisprudencial-da-tributacao-do-direito-de-imagem-de-artistas-e-atletas-05102015>. Acesso em: 15 mar. 2017. 
NETO, L. F. Teorias do "abuso" no planejamento tributário. Dissertação (Mestrado em Direito Tributário) - Universidade de São Paulo, São Paulo, 2011.

NOVELINO, M. Manual de direito constitucional. 9. ed. São Paulo: Método, 2014 .

SILVA, F. F. Tributação no futebol : clubes e atletas. São Paulo: Quartier Latin, 2009.

ZAINAGHI, D. S. Os atletas profissionais de futebol no direito do trabalho. 2. ed. São Paulo: LTr, 2015. 


\title{
EX-TARIFÁRIO: POSSIBILIDADE DE EXTENSÃO DOS EFEITOS DA RESOLUÇÃO PUBLICADA PELO PODER EXECUTIVO QUE O INSTITUI
}

\author{
Paulo Alfredo Benfica Marra ${ }^{1}$ \\ Ernst \& Young
}

Artigo recebido em: 30/06/2019.

Artigo aceito em: 27/08/2019.

\section{Resumo}

Os benefícios tributários concedidos pretendida. Nesse contexto, com fulcro na importação, entre os quais se inclui o Ex-Tarifário, por vezes têm sua fruição prejudicada pela morosidade que afeta o Poder Executivo no ato de formalização do benefício. E mais, não é incomum que, apesar de preenchidos os requisitos que permitam ao contribuinte gozar do benefício fiscal, por exemplo, quando diante de uma mera renovação deste, em virtude da demora dos procedimentos para a publicaçáo da Resoluçáo formal pela CAMEX, os importadores acabam por, no fato gerador do Imposto de Importação, não ter oficializada tal redução tributária principalmente na jurisprudência mais recente do Superior Tribunal de Justiça e dos Tribunais Regionais Federais, podemos perceber que os entendimentos vêm se tornando uníssonos no sentido de que a Resoluçáo a ser publicada tem efeito meramente declaratório, estendendo-se o benefício ali formalizado às Declaraçōes de Importação registradas desde o momento do requerimento de concessão ou renovação do Ex.

Palavras-chave: CAMEX; Ex-Tarifário; extensão de efeitos; imposto de importação; STJ.

EX-TARIFF: POSSIBILITY OF EXTENSION OF THE EFFECTS OF THE RESOLUTION PUBLISHED BY THE EXECUTIVE AUTHORITY THAT INSTITUTES IT

\section{Abstract}

The tax benefits granted on importation, formalization of the benefit. In addition, including the Ex-Tariff, sometimes end it is not uncommon that although the up being impaired by the delay that requirements for tax relief are met, affects the Executive Power in the act of for example, when faced with a mere

1 Pós-Graduado em Direito Tributário pela Universidade Fumec. Graduado em Direito pela Escola Superior Dom Helder Câmara (2017). Consultor Tributário da Ernst \& Young, com atuação voltada a tributos indiretos e aduaneiros. Membro da Comissão de Direito Aduaneiro da OAB/MG e da Associação Brasileira de Direito Tributário. 
renewal of the benefit due to the delay in the procedures for the publication of the formal CAMEX Resolution, importers pay the Import Tax based on the full aliquot, because the benefit was not formalized by the Executive. In this context, based on the most recent jurisprudence of the Superior Court of Justice and the Federal Regional Courts, it is clear that the understandings are becoming unison, in the sense that the Resolution to be published has merely declaratory effect, expanding the benefit formalized for the registered DIs from the moment of application of the concession or renewal of the Ex-Tariff.

Keywords: CAMEX; Ex-Tariffs; effects extension; import tax; STJ.

\section{Introdução}

Nas últimas décadas, as negociaçóes internacionais e, via de consequência, o comércio exterior, foram muito expandidas ao redor do mundo. Como forma de ilustrar tal cenário, devemos nos atentar aos números, critério objetivo de avaliação, que dizem respeito à exportação e à importação, divulgados pela própria Autoridade Aduaneira no território nacional. Se compararmos, por exemplo, o valor $\mathrm{FOB}^{2}$ que movimentou as importaçóes em 1997, temos o valor apurado de US\$ 597.472.270,88, ao passo que, em 2017, a totalidade dos valores FOB movimentados no País atinge a marca de US\$ $1.507 .494 .529,49$, quase o triplo. No que toca à exportação, seguindo a mesma ordem anterior, temos a apuração de US\$ 529.827.258,29 e US\$ 2.177.391.770,77, respectivamente (BRASIL, 2018a).

Fatalmente, não há como separar tal evolução do comércio internacional, por exemplo, a evolução dos meios de comunicação e as facilidades de locomoção e transporte hoje encontradas que, sem sombra de dúvidas, impóem-se como ferramentas essenciais para o bom desenvolvimento das operaçóes internacionais de comércio. Junto à evolução dessas ferramentas, cresce incessantemente a busca por melhoria, de modo que não há óbice em dizer, portanto, que as relaçôes comerciais em âmbito internacional possibilitam que o câmbio de produtos tenha seu fluxo aumentado e, via de consequência, estimule o desenvolvimento nacional e das tecnologias, de tal maneira que as possibilidades internas de determinado país acabam por acompanhar tal relação negocial.

Pensando nisso, o Brasil, em 1990, instituiu benefício fiscal aos importadores

2 Nesse incoterm o vendedor entrega a mercadoria ao comprador a bordo do navio através do qual ocorrerá o translado da operação comercial firmada. Todos os riscos de perda ou dano desta são transferidos ao comprador no exato momento em que há a entrega, pelo vendedor, no porto de embarque nomeado. Quando aplicáveis, os trâmites alfandegários na exportação são por conta do vendedor; já na importação, tais trâmites são ônus do comprador (KEEDI, 2016). 
denominado Ex-Tarifário que, em suma, consistia em uma maneira de zerar a alíquota incidente no Imposto de Importação em relação às máquinas e aos equipamentos tecnológicos sem similares nacionais (PIANI; MIRANDA, 2006). Nos primeiros anos de funcionamento desse tratamento de tributação diferenciada, a indústria nacional não viu com bons olhos a exceção tributária concedida aos importadores. É que na visão destes, “o uso de Ex-Tarifários em número elevado, com descrições específicas, sem a observância das regras universais de nomenclatura de mercadorias, incentivava fraudes em prejuízo da produção doméstica" (PIANI; MIRANDA, 2006).

Assim, tendo em vista a forte pressão feita pelos fabris nacionais, em meados de 1997, o Ministério da Fazenda e o Ministério da Indústria, do Comércio e do Turismo se viram obrigados a revogar a exceção tarifária em comento, concedida através do regime de Ex-Tarifário. À época, as listas de isençôes abrangiam cerca de 3,7 mil itens (PIANI; MIRANDA, 2006).

De mais a mais, por forte influência política do governo Fernando Henrique Cardoso, presidente do País naquele tempo, ainda em 1997, os Ex-Tarifários voltaram ao cenário da economia nacional, tendo sido reintroduzidos através da Portaria CAMEX n. 337, de 19 de dezembro de 1997. A referida Portaria vigeu e regulamentou a exceção tributária em questão até o ano de 2001, quando fora publicada a Resolução CAMEX específica acerca dos procedimentos para a concessão de Ex-Tarifários. Hoje, vige a Resolução CAMEX n. 66, de 14 de agosto de 2014, como a principal norma norteadora do benefício fiscal em questão e dos procedimentos atinentes a seu pleito (BRASIL, 2014).

Feita essa breve contextualização acerca do surgimento do Ex-Tarifário, é importante definir o que é tal regime de tributaçáo diferenciada. Nesse sentido, é importante destacar o que dispóe o art. 17 do Decreto-Lei n. 37/66, um dos principais diplomas legais em matéria aduaneira, que consigna a possibilidade de exceções tributárias ao dizer que "a isenção do Imposto de Importação somente beneficia produto sem similar nacional, em condições de substituir o importado" (BRASIL, 1966b). Não obstante, sob esse mesmo prisma, podemos nos remeter ao que o próprio Ministério da Industria, Comércio Exterior e Serviço, atualmente o maior responsável pela instituição do referido benefício fiscal, consigna:

O regime de Ex-Tarifário consiste na redução temporária da alíquota do imposto de importaçáo de bens de capital (BK), de informática e telecomunicação (BIT), assim grafados na Tarifa Externa Comum do Mercosul (TEC), quando não houver a produçâo nacional equivalente (BRASIL, 2019). 
Buscando uma conceituação um pouco mais aprofundada de como definir os Ex-Tarifários, vejamos a lição a seguir, extraída da obra de Dalston (2005), elaborada única e exclusivamente sobre o tema:

Assim sendo, a expressão "exceçâo tarifária" deve ser traduzida como alteraçấo, para mais ou para menos, na alíquota ad valorem de um tributo, em especial, na sua espécie mais destacada, qual seja, o imposto, objetivando, por exemplo, estimular, ampliar ou reestruturar um ou mais setores da economia ou, de forma indireta, atuar nas citadas direçôes equalizando as condiçóes para a saudável competiçấo entre as empresas num determinado mercado [...] (DALSTON, 2005, p. 52).

Dito isso, algumas perquiriçóes são necessárias. A primeira delas, certamente, trata-se de elucidar o que é a Tarifa Externa Comum (TEC) retromencionada. Para tanto, é fundamental que tenhamos em mente que, para o Imposto de Importação, a alíquota definida em nosso ordenamento jurídico determina que terá natureza ad valorem ${ }^{3}$, ou seja, os produtos terão uma porcentagem previamente estabelecida que, após aplicada à base de cálculo para o referido tributo, terá como resultado o quantum tributário a ser pago a esse título. Essa "porcentagem prévia" está elencada na TEC que, em suma, consiste em uma tabela desenvolvida pelos órgãos governamentais responsáveis pelo comércio exterior no Brasil, junto a outros países-membros do Mercosul, onde, através da Nomenclatura Comum do Mercosul (NCM) - código dado às mercadorias e que permite sua identificação na TEC, estabelece a alíquota que deve incidir sobre cada mercadoria a ser nacionalizada em território brasileiro.

Com relação à definição das Exceções Tarifárias como um gênero e, no caso ora analisado, tendo o Ex-Tarifário como uma espécie, entendimento o qual é possível extrair da leitura da citação de Dalston (2005) feita anteriormente, concordamos integralmente. Não obstante, ousamos externar raciocínio diferente no que tange à impossibilidade de considera-lo um benefício fiscal, sendo plausível um breve comentário, ainda que pouco influenciará o recorte metodológico deste trabalho. Pois bem. Nessa esteira, é bem claro no ordenamento jurídico vigente a distinção existente entre a isenção tributária e a alíquota zero ou reduzida, sendo esta última aplicável ao caso. Outrossim, a existência de uma distinção entre esses dois institutos tributários não é suficiente para impossibilitar chamar um

3 A alíquota a ser aplicada é definida pela chamada Tarifa Externa Comum (TEC) do Mercosul ou na sua Lista de Exceções. Cabe ressaltar, forte na autorização constante do art. 153, § $1^{\circ}$, da CRFB, e do art. 21 do CTN, que o Poder Executivo, observadas as condições e os limites estabelecidos em lei, pode alterar as alíquotas do Imposto sobre a Importação, "a fim de ajustá-lo aos objetivos da política cambial e do comércio exterior" (PAULSEN; MELO, 2015, p. 301). 
deles de benefício fiscal e outro não, haja vista que, ambos, analisando inclusive a extrafiscalidade que acompanha o Imposto de Importação, são, sim, incentivos fiscais com a finalidade única de fomentar a entrada no País, no caso do Ex., de tecnologias não produzidas nacionalmente e que têm potencial para auxílio no desenvolvimento nacional. Assim, ainda que não influencie em nada no cerne central do presente estudo, trataremos o Ex-Tarifário como um benefício fiscal ao longo deste texto.

Ocorre que, ainda que muito bem-conceituado pela legislação vigente, o instituto do Ex-Tarifário, na prática, a fruição do benefício nâo vem ocorrendo de maneira fluida. Isso pois, além de preencher os requisitos necessários para a concessão do benefício, sua aplicação de fato depende de ato do Poder Executivo que, em função até mesmo do pouco pessoal disponível, acaba por incorrer em morosidade para fazê-lo. A consequência disso é, primeiro, prejuízo aos importadores, pois no momento do fato gerador acabam por ter uma alíquota cheia em relação aos impostos abarcados pelo Ex. e, via de consequência, na propositura de açóes no judiciário, com o intuito de fazer valer seu direito de importar com a alíquota reduzida.

Nesse contexto e, a uma, com fulcro na legislação vigente sobre o tema e, a duas, da mais atual jurisprudência sobre o tema para a performance deste trabalho e para alcançarmos as conclusôes a seguir expostas. Fato é que, de maneira quase que uniforme, com algumas pouquíssimas ressalvas, o judiciário náo ratifica a conduta do Estado - lato sensu -, no intuito de impedir o gozo do benefício, ainda que o importador tenha cumprido com todo o necessário para fazê-lo.

Após o exposto, é possível adentrar o tema principal, fazendo algumas consideraçôes preliminares, porém, fundamentais para o entendimento do que se pretende expor como conclusão.

\section{Do procedimento para obtençáo do Ex-Tarifário}

A obtenção do Ex-Tarifário segue algumas normas e procedimentos a serem observados pelo requerente do benefício. Em suma, a Resolução CAMEX n. 66, de 14 de agosto de 2014, é a legislação que rege os procedimentos que serão brevemente expostos adiante.

Os requerimentos formais para a concessão ou renovação de Ex-Tarifário deverão ser encaminhados, em conjunto aos demais documentos exigidos pelo art. $2^{\circ}$ da Resoluçáo supramencionada, para uma análise prévia documental e da Secretaria da Receita Federal acerca da descrição e classificação do produto objeto do pleito. Em seguida, deverá a Autoridade Pública abrir espaço, através 
de edital público a ser disponibilizado no Diário Oficial, para que, através de suas associaçóes, empresas do segmento a serem atingidas pelo Ex-Tarifário eventualmente concedido manifestem-se acerca da existência, ou não, de similar nacional do produto que se pretende importar sob alíquota zero ou reduzida. Decorrido o prazo, o requerimento, seus documentos e os pareceres emitidos até então serão encaminhados à Secretaria do Desenvolvimento e Competitividade Industrial.

A SDCI será a responsável pela análise técnica do produto. Após a análise por parte da SDCI, o processo administrativo de concessão ficará sob os cuidados do Comitê de Análise de Ex-Tarifários - CAEX que, por sua vez, compóe-se de um representante da Secretaria de Desenvolvimento e Competitividade Industrial (SDCI), um representante da Secretaria Executiva da CAMEX (SE-CAMEX) e um representante do Banco Nacional de Desenvolvimento Econômico e Social (BNDES), cuja função é, basicamente, examinar os pareceres elaborados pela SDCI sobre o preenchimento dos requisitos da legislação para a concessão de Ex-Tarifário de que trata esta Resolução (BRASIL, 2018b). O parecer final será dado pela GECEX (Comitê Executivo de Gestão), núcleo executivo colegiado da CAMEX. Feito isso, são duas as opçôes da CAMEX: o deferimento ou o indeferimento do pleito, sendo que, nessa última hipótese, deverá expor os motivos que o levaram a essa conclusão.

O deferimento do pleito far-se-á através de Resolução a ser publicada pela CAMEX. Via de regra, todo esse processo demora cerca de 90 (noventa) dias, sendo prudente destacar que vários fatores internos e externos podem influenciar na agilidade ou na morosidade do procedimento. É aqui que passa a ser possível a compreensão no tocante ao problema central a ser tratado neste trabalho.

Como visto, a concessão de um Ex-Tarifário depende, primordialmente, de dois fatores: o enquadramento do bem objeto do pleito como bem de capital (BK), de informática ou telecomunicação (BIT) e, também, da ausência de produção de similar nacional. Assim sendo, é de se presumir que o requerente do benefício fiscal, ao pleiteá-lo, está ciente de tais condições e, via de regra, cumpre com os requisitos exigidos para tanto. Em consequência, é inegável que há uma expectativa de direito criada, qual seja, de importar mercadorias enquadradas como passíveis de redução de alíquota que, todavia, por muitas vezes, é postergada em virtude da morosidade que acompanha todo e qualquer ato da Administração Pública em nosso País.

No caso específico dos Ex-Tarifários, em tese, não haveria como usufruir do benefício que o acompanha sem antes ocorrer a publicação da Resolução CAMEX que formalize a inclusão do bem a ser importado na Lista de Exceçóes à TEC. Assim, o importador, apesar de cumpridos todos os requisitos para usufruir do 
benefício fiscal, ficaria impossibilitado de fazê-lo, arcando com um ônus tributário maior do que o planejado em sua operação. Ocorre que, ciente de tal cenário caótico e totalmente desestimulante àquele que pretende trazer ao território nacional tecnologias antes não vistas, a jurisprudência vem se manifestando de maneira a dar a tais importadores a possibilidade de gozo dessa redução de alíquota antes mesmo da manifestação final do Poder Executivo.

Após as breves consideraçóes sobre o Imposto de Importação e os reflexos da Exceção Tarifária aqui tratada, torna-se patente a análise da solução jurídica dada pelo Superior Tribunal de Justiça para casos em que a expectativa de direito e o gozo do benefício fiscal fiquem à mercê de uma demorada manifestação da Administração Pública que, por sua vez, conforme recentes entendimentos, apresenta natureza meramente formal.

\section{Imposto de Importação e os reflexos do Ex-Tarifário}

Seguindo uma ordem normativa cronológica, é de se dizer que o Imposto de Importação foi legalmente instituído pelo Decreto-Lei n. 37/66, bastante alterado pelo Decreto-Lei n. 2.472/88 e, ainda, posteriormente, teve suas normas gerais estabelecidas no Código Tributário Nacional, mais precisamente dos arts. 19 ao 22 desse livro legal.

$\mathrm{Na}$ seara da Constituição Federal vigente, vê-se o Imposto de Importação previsto expressamente no art. 153 e presente também nos princípios constitucionais tributários previstos no art. 150 , sendo que a tratativa de cada um desses dois artigos estabelece para o referido tributo delineamentos essenciais. $\mathrm{O}$ art. 153, inc. I, por exemplo, determina a competência da União para instituir o imposto sobre a importação de produtos estrangeiros, ao passo que o art. 150 traz as limitaçóes e exceçôes ao poder de tributar do retromencionado ente federativo.

Assim, é possível perceber que, durante a evolução histórica do Brasil, a começar por 1966, em que se teve a primeira regulamentação atinente ao Imposto de Importação, muitas modificaçôes ocorreram, em razão da evolução das relaçôes jurídicas supervenientes. Ocorre que, no atual cenário e, ainda, em virtude da possibilidade de o Poder Executivo regular o referido tributo, são constantes as ediçóes de Instruçôes Normativas, Leis, Decretos e Resoluçôes no tocante ao Imposto de Importação.

O Imposto de Importação tem como principal característica sua utilização preponderantemente como um tributo extrafiscal. Tal natureza se dá em razão de sua função não ser meramente arrecadatória, ou seja, com o condão de 
recolhimento de valores aos cofres públicos. $\mathrm{Na}$ verdade, um imposto extrafiscal tem a finalidade de conceder à Administraçáo Pública a possibilidade de, através da regulação deste, estimular ou desestimular um comportamento do contribuinte e de qualquer outro afetado pelo referido tributo. A propósito:

A par da forma de imposição tradicional, voltada com exclusividade à arrecadação de recursos financeiros (fiscais) para o atendimento das necessidades coletivas, exsurge a tributação extrafiscal, que se orienta para o fim ordenador e reordenador da economia e das relaçốes sociais, e não para a missão meramente arrecadadora de riquezas (SABBAG, 2016, p. 290).

Assim, exemplificando, com o intuito de retirar do campo teórico e trazer ao campo fático o que fora dito há pouco, o Imposto de Importação é um importante mecanismo utilizado pelo Poder Público para, a uma, estimular a economia nacional e, em paralelo, valorizar o produto nacional em detrimento do estrangeiro. É o caso, por exemplo, de fazer incidir certa carga tributária em um eletrônico trazido do estrangeiro, com a finalidade de fazer o consumidor avaliar se, de fato, o somatório do preço do produto estrangeiro agregado à tributaçấo nele incidente ainda possui um custo-benefício que faça valer sua aquisiçáo se comparado ao nacional, no qual não se vê presente tal tributação, por óbvio.

Para tanto, o Imposto de Importação, à luz do que permite a Constituição Federal e, ainda, em clara exceção aos princípios ali previstos, no que toca à limitaçấo ao poder de tributar que atinge os Entes Federativos, faz uso de duas importantes ferramentas: 1) a não aplicação ao II do princípio da anterioridade tributária, seja a nonagesimal ou do ano de exercício e, ainda; 2) goza de uma clara atenuação no que diz respeito ao princípio da legalidade tributária.

Com relaçáo à atenuação à legalidade tributária, via de regra, para que seja alterada qualquer disposição referente a um tributo e, inclusive para que seja um novo tributo incluído no cenário tributário nacional, necessário se faz que tal alteração, exclusão ou inclusão seja através de Lei, que obedecerá aos trâmites legalmente previstos até sua entrada em vigência. Ocorre que, no que diz respeito ao Imposto de Importação, a regra geral não se aplica, conforme demonstra o art. 21, do CTN:

Art. 21. O Poder Executivo pode, nas condiçōes e nos limites estabelecidos em lei, alterar as alíquotas ou as bases de cálculo do imposto, a fim de ajustá-lo aos objetivos da política cambial e do comércio exterior (BRASIL, 1966a). 
Sob esse mesmo prisma, a Constituição Federal, frise-se, publicada posteriormente ao Código Tributário Nacional, em seu art. 153, $\$ 1^{\circ}$ dispóe que "é facultado ao Poder Executivo, atendidas as condiçôes e os limites estabelecidos em lei, alterar as alíquotas dos impostos enumerados nos incs. I, II, IV e V"^. Ora, é sabido que toda e qualquer disposição materialmente contrária à Constituição Federal deve ser considerada inconstitucional, tendo em vista a hierarquia normativa que acompanha nosso ordenamento jurídico. Assim, nota-se que o disposto no art. 21 do CTN aplica-se apenas em parte nos dias atuais, tendo em vista que a $\mathrm{CF} / 88$ não estendeu a exceção ao princípio da legalidade tributária à alteração da base de cálculo do Imposto de Importação, mas tão somente de sua alíquota.

Dessa maneira e tendo em mente o que foi anteriormente dito sobre a característica extrafiscal do Imposto de Importação, o Poder Executivo pode, através de simples Resolução, por exemplo, a ser publicada pela Câmara de Comércio Exterior (CAMEX), alterar a alíquota aplicável ao referido tributo. Vale frisar que, atualmente, as alíquotas no tocante ao II são aplicadas na maioria dos casos de maneira ad valorem, de modo que cada produto possui uma alíquota predeterminada a incidir no caso de sua importação para o Brasil. Para chegar ao montante final devido, deve ser multiplicada a alíquota incidente à base de cálculo que, in casu, é o valor aduaneiro da mercadoria importada 5 .

Com a correta utilização dessa ferramenta, levando em consideração a produção nacional de um certo produto ou, se for o caso, a necessidade de estímulo da economia nacional através de transaçóes internacionais, o Poder Executivo pode optar por majorar ou minorar a alíquota de determinado bem a ser importado. Nessa esteira, outro importante princípio tributário é excepcionado para o Imposto de Importação, qual seja, o da anterioridade, de modo a tornar possível a 4 Art. 153. Compete à União instituir impostos sobre:

I - importação de produtos estrangeiros;

II - exportação, para o exterior, de produtos nacionais ou nacionalizados;

III - renda e proventos de qualquer natureza;

IV - produtos industrializados;

V - operações de crédito, câmbio e seguro, ou relativas a títulos ou valores mobiliários;

VI - propriedade territorial rural;

VII - grandes fortunas, nos termos de lei complementar (BRASIL, 1988).

5 Art. 1 do Acordo de Valoração Aduaneira:

O valor aduaneiro de mercadorias importadas será o valor de transação, isto é, o preço efetivamente pago ou a pagar pelas mercadorias em uma venda para exportação para o país de importação, ajustado de acordo com as disposições do art. 8, desde que:

(a) não haja restrições à cessão ou à utilização das mercadorias pelo comprador, ressalvadas as que:

(i) sejam impostas ou exigidas por lei ou pela administração pública do país de importação;

(ii) limitem a área geográfica na qual as mercadorias podem ser revendidas; ou

(iii) não afetem substancialmente o valor das mercadorias;

(b) a venda ou o preço não estejam sujeitos a alguma condição ou contraprestação para a qual não se possa determinar um valor em relação às mercadorias objeto de valoração;

(c) nenhuma parcela do resultado de qualquer revenda, cessão ou utilização subsequente das mercadorias pelo comprador beneficie direta ou indiretamente o vendedor, a menos que um ajuste adequado possa ser feito de conformidade com as disposições do art. 8; e

(d) não haja vinculação entre o comprador e o vendedor ou, se houver, que o valor de transação seja aceitável para fins aduaneiros, conforme as disposições do parágrafo 2 deste artigo (BRASIL, 1994). 
aplicação desde logo da alíquota alterada, sem necessidade de se observar nenhum prazo mínimo para tal. A alteração, conforme exposta anteriormente, é o retrato exato do que acontece quando do deferimento do Ex-Tarifário pleiteado por determinado importador, no caso, com a clara finalidade de fomentar a importação de determinado produto ou bem. Assim, é de ser dizer que não há necessidade de se observar os prazos de anterioridade nonagesimal e do ano de exercício, regra geral estabelecida no art. 150, III, $b$ e $c$, da Constituiçáo Federal para o Imposto de Importação.

Dessa feita, interpretando em conjunto as exceçôes atribuídas ao I.I., é possível concluir que, além de ser possível a alteração de sua alíquota por via de Resolução/Decreto editada pelo Poder Executivo, tal alteração não se sujeita a nenhum prazo mínimo para início de sua aplicação, conquanto produzirá efeitos desde sua publicação até que sobrevenha Decreto ou Lei posterior que a revogue. Dito isso, fica muito claro o caráter extrafiscal do tributo aqui tratado e, ainda, como é concedido ao Poder Executivo a possibilidade de controlá-lo. Através da alteração das alíquotas de uma mercadoria, a Administração Pública consegue, de forma direta e indireta, intervir na economia nacional, estimulando a compra de certos produtos e desestimulando a de outros, tais como cigarros e bebidas alcoólicas, que atualmente sofrem forte carga tributária quando importados para o Brasil ${ }^{6}$.

Com tais exceçôes em mente, outro ponto muito importante deste capítulo deve ser destacado: o fato gerador do Imposto de Importação. Nesse ponto, não há discussão assentada, mas, ainda assim, vale a exposição.

A norma tributária pode ser vista sob vários aspectos, entre eles o aspecto material que, em síntese, trata do fato gerador de incidência do tributo. Este, por sua vez, deságua quando da interpretação dos demais aspectos, tais como o espacial, que determina o território em que a ocorrência do fato gerador implica a incidência do tributo ou, ainda, o temporal, que prevê o momento em que deve ser considerado ocorrido o fato gerador. Percebe-se, portanto, a tamanha importância de se ver bem elucidada a questão do fato gerador do Imposto de Importação. O fato gerador é assim definido por Geraldo Ataliba:

$\mathrm{Na}$ impossibilidade de avaliar, ainda que aproximadamente, a capacidade contributiva dos sujeitos à sua soberania - pelos inconvenientes óbvios representados pela necessidade de constante e inquisitorial investigação das atividades e patrimônio dos contribuintes - adota o direito financeiro, na conformidade

6 Em consulta à TEC, é possível verificar que o cigarro, por exemplo, classificado na NCM 2402.20.00 - Cigarros que contenham tabaco, possuem uma carga tributária no que toca ao Imposto de Importação de $20 \%$, a ser calculado sobre seu valor aduaneiro, base de cálculo legalmente instituída para tal. Com relação às bebidas alcoólicas, temos que aquelas classificadas na NCM 2203.00.00 - Cervejas de malte, sofrem a incidência de alíquota idêntica de $20 \%$. 
dos ensinamentos científicos das finanças públicas, a técnica de eleger uns tantos fatos da vida econômica, de maior relevância, e fazê-los objeto da tributação.

Em o fazendo, o direito financeiro estabelece ipso facto a presunção de que tais fatos, desde que verificados, indiciam capacidade econômica e, via de consequência, capacidade contributiva, por parte de quem os pratica, dá causa, ou ainda deles se beneficia. A tais fatos da vida econômica, revestidos ou não de roupagem jurídica (forma jurídica) se dá o nome de fatos geradores ou fatos imponíveis (ATALIBA, 1966, p. 161).

O art. 19 do CTN prevê que "o imposto, de competência da União, sobre a importaçáo de produtos estrangeiros tem como fato gerador a entrada destes no território nacional” (BRASIL, 1996a). Assim, evidente que a entrada de produtos estrangeiros no território nacional é o fato jurídico que caracteriza a incidência do Imposto de Importação em matéria tributária.

Devidamente esclarecido o fato jurídico, o qual se permitirá à Administração Pública a cobrança do Imposto de Importação, passemos a uma breve exposição sobre outros aspectos importantes acerca do Imposto de Importação: o temporal, o espacial, o pessoal e o quantitativo, fundamentais para a perfeita interpretação do que determina o ordenamento jurídico vigente no tocante à incidência do retromencionado tributo, com o devido destaque ao quantitativo, já que diretamente ligado ao problema a ser tratado no presente texto.

O aspecto temporal de um tributo é aquele pelo qual se torna possível verificar quando exatamente deve ser considerado ocorrido seu fato gerador. No caso do Imposto de Importação, tal previsão encontra-se no art. 23 do Decreto-Lei n. 37/66, que dispóe: "quando se tratar de mercadoria despachada para consumo, considera-se ocorrido o fato gerador na data do registro, na repartição aduaneira, da declaração a que se refere o art. 44" (BRASIL, 1966b). Inconteste, portanto, que a o aspecto temporal do II fica estabelecido como o momento em que se submete a mercadoria importada ao despacho aduaneiro ${ }^{7}$, ou seja, quando há o registro da Declaração de Importaçáo do bem e, efetivamente, vê-se concretizada sua nacionalização.

O aspecto espacial de um tributo nos permite perceber o território em que a ocorrência do fato gerador concretiza a incidência da carga tributária que lhe

$7 \mathrm{O}$ despacho aduaneiro é um procedimento administrativo-fiscal ao qual são submetidas todas as mercadorias a serem desembaraçadas no território nacional. No referido procedimento, serão verificados os dados conforme declarados pelo Importador para, ao fim, ser realizado o desembaraço aduaneiro que, por sua vez, nos termos do art. 571, do Regulamento Aduaneiro, é o ato pelo qual é registrada a conclusão da conferência aduaneira. 
é atinente. Para tanto, é necessário ressaltar o que dispóe o art. 19 do Código Tributário Nacional, que determina como território de incidência do Imposto de Importação o "território nacional", ou seja, toda a extensão territorial do Brasil quando sofre o ingresso de uma mercadoria estrangeira capaz de incorporar valores à economia nacional com sua permanência no país.

Nos termos do art. 20 do CTN, a alíquota a ser aplicada ao Imposto de Importação, quando de sua incidência, pode ter natureza específica ou ad valorem. Atualmente, a alíquota ad valorem é a hipótese mais comumente aplicada, que implica a existência de um percentual que incidirá sobre o valor da importação como um todo.

No que toca às alíquotas a serem aplicadas, atualmente, encontram-se especificadas na TEC - Tarifa Externa Comum, que se apoia na codificação da NCM - Nomenclatura Comum do Mercosul ${ }^{8}$. Em suma, tal sistema permite uma uniformização das alíquotas sobre os produtos em relação aos países-membros do Mercosul, na tentativa de não criar uma desleal concorrência que seria possível no caso de livre arbitramento das alíquotas por cada país-membro.

A base de cálculo do Imposto de Importação será determinada pelo valor da importação que, por sua vez, será apurado de acordo com o valor aduaneiro da operação que será auferido pelos métodos previstos no Acordo de Valoração Aduaneira, observada a ordem ali imposta e, também, os princípios intrínsecos e extrínsecos que lhe são atinentes. Sobre o tema, é importante destacar que:

A referência, no art. 20, II, do CTN, ao preço para entrega no porto ou lugar de entrada do produto no País já indicava para uma base de cálculo que extrapola o preço do produto para alcançar os custos de transporte e de seguro, remetendo ao chamado preço CIF (Cost, Insurance And Freight). Essa sigla representa cláusula comercial que obriga o vendedor tanto pela contratação e pagamento do frete como do seguro marítimo por danos durante o transporte. A adoçáo do preço CIF resta desdobrada na legislação aduaneira, conforme se vê do Decreto 2.498/98, o que resta autorizado pelo art. $8^{\circ}$ do Acordo de Valoraçáo Aduaneira (PAULSEN; MELO, 2015, p. 22).

8 Como previsto no Tratado de Assunção, a partir de 01/01/95, os quatro Estados Partes do Mercosul adotaram a Tarifa Externa Comum (TEC), com base na Nomenclatura Comum do Mercosul (NCM), com os direitos de importação incidentes sobre cada um desses itens. Segundo as diretrizes estabelecidas, desde 1992, a TEC deve incentivar a competitividade dos Estados Partes e seus níveis tarifários devem contribuir para evitar a formação de oligopólios ou de reservas de mercado. Também foi acordado que a TEC deveria atender aos seguintes critérios: a) ter pequeno número de alíquotas; b) baixa dispersão; c) maior homogeneidade possível das taxas de promoção efetiva (exportações) e de proteção efetiva (importação); d) que o nível de agregação para o qual seriam definidas as alíquotas era de seis dígitos. A aprovação da TEC também incluiu alguns mecanismos de ajuste das tarifas nacionais, através de Listas de Exceções, com prazos definidos para convergência aos níveis da TEC (MDIC, s.d). 
Ainda sobre o tema, destaca-se a redação dada ao art. $2^{\circ}$, do Decreto-Lei 37/66 após a alteraçáo trazida pelo Decreto-Lei 2.472/88 que determina que, em se tratando de alíquota ad valorem, o valor aduaneiro há de ser apurado segundo as normas do art. $7^{\circ}$ do Acordo Geral sobre Tarifas Aduaneiras e Comércio - GATT.

Feitas essas consideraçóes acerca do Imposto de Importação, necessário se faz uma análise macro do que fora esclarecido. Isso pois, desde as exceçóes tributárias constitucionalmente previstas na Carta Magna até as características específicas do tributo que configuram o imposto aqui tratado, tudo isso mostra-se fundamental para se compreender quais de fato são os reflexos do Ex-Tarifário.

Primeiramente, no tocante às exceçóes ao poder de tributar supraexaltadas, tem-se que, no que toca a da legalidade, a concessão do Ex-Tarifário através de Decreto emitido pela CAMEX é perfeitamente admitida em nosso ordenamento jurídico. Sob esse mesmo prisma, a exceção à anterioridade tributária nos permite concluir que, com a Resolução permissiva de minoraçâo da alíquota do Imposto de Importação para determinado produto, passa tal determinação viger de imediato, sem que se imponha um prazo mínimo para que sua aplicação tenha validade.

Assim e, ainda, analisando que o objetivo central do Ex. é, em suma, reduzir temporariamente a alíquota do Imposto de Importação para bens de capital e bens de informática e telecomunicaçôes, sem produção nacional, não se pode esperar que, cumprido o procedimento administrativo necessário para a formalização de seu pleito, o importador tenha que esperar que se esvaia a morosidade que eiva nossa Administração Pública para, apenas depois, fazer-se valer do benefício que lhe é de direito. É a partir daí que muitos desses importadores, desgastados pela necessidade de esperar uma mera formalização de direito que já fazia jus desde o pleito para concessão, ou renovação, de Ex-Tarifário, começaram a intentar diversas açôes judiciais a fim de que se aplicasse um efeito extensivo ao ato de publicação da Resolução CAMEX que oficializa a inclusão de determinada mercadoria da Lista de Exceçôes da Tarifa Externa Comum (LETEC).

\section{Possibilidade de extensão de efeitos da Resolução CAMEX a fato gerador já configurado}

É evidente que, haja vista o nítido caráter regulatório ou extrafiscal do Imposto de Importação, o reconhecimento pelo próprio órgão regulamentador do comércio exterior, através da concessão do Ex-Tarifário, apenas corrobora o que já foi dito de que os produtos importados sob esse benefício fiscal podem trazer muitos benefícios para a economia nacional. Tais benefícios são percebidos desde o estímulo e fomentação do desenvolvimento da indústria nacional até a geraçáo de empregos. 
Ao pleitear o referido regime de tributação para o bem a ser importado, é natural que as empresas já tenham cumprido todos os requisitos necessários para sua concessão ou renovação, principalmente aquele tratado como primordial, ou seja, a verificação da ausência de similar produzido no país. Isso pois, antes de uma operação desse porte, uma pesquisa de mercado é o mínimo que se espera de um comerciante transnacional, e ademais, ao pleitear o incentivo fiscal, as associaçóes nacionais que congregam as indústrias que poderiam produzir o bem a ser importado são consultadas. Não obstante, o importador acaba por ficar um tempo considerável à espera da formalização do benefício, apenas aguardando a apreciação e a publicação da resoluçáo correspondente. Tal fato pode atrasar e, até mesmo, inviabilizar a importação que deu azo à solicitação de Ex-Tarifário, culminando em prejuízo sem precedentes ao operador.

Assim, vê-se o importador na seguinte situação: não obstante o cumprimento de todos os requisitos para gozo do benefício decorrente da concessão ou renovação do Ex-Tarifário, em total observância à legislação em vigência, o empecilho acaba por ser fato alheio a sua vontade ou que ele possa resolver, ou seja, a ausência de publicação da Resolução CAMEX que formalizará sua concessão ou, se for o caso, renovação.

Dito isso, devemos destacar, de plano, que a legislação, há muito tempo, traz a possibilidade de concessão de isenção ou redução do Imposto de Importação e, via de consequência, dando embasamento jurídico ao regime de tributação do Ex-Tarifário. Nesse sentido, é dispositivo legal a seguir colacionado, extraído da Lei n. 3.244/57:

Art. $3^{\circ}$. Poderá ser alterada dentro dos limites máximo e mínimo do respectivo capítulo, a alíquota relativa a produto:

a) cujo nível tarifário venha a se revelar insuficiente ou excessivo ao adequado cumprimento dos objetivos da Tarifa;

b) cuja produçáo interna for de interesse fundamental estimular;

c) que haja obtido registro de similar;

d) de país que dificultar a exportação brasileira para seu mercado, ouvido previamente o Ministério das Relaçôes Exteriores;

e) de país que desvalorizar sua moeda ou conceder subsídio à exportação, de forma a frustrar os objetivos da Tarifa.

$\$ 1^{\circ}$ - Nas hipóteses dos itens "a", "b" e "c" a alteração da alíquota, em cada caso, não poderá ultrapassar, para mais ou para menos, a 30\% (trinta por cento) "ad valorem".

$\$ 2^{\circ}-\mathrm{Na}$ ocorrência de “dumping”, a alíquota poderá ser elevada até o limite capaz de neutralizá-lo (BRASIL, 1957). 
Do mesmo diploma legal, também podemos extrair a seguinte leitura:

Art. $4^{\circ}$ - Quando não houver produção nacional de matéria-prima e de qualquer produto de base, ou a produçáo nacional desses bens for insuficiente para atender ao consumo interno, poderá ser concedida isençáo ou reduçáo do imposto para a importação total ou complementar, conforme o caso.

A Carta Magna corrobora com a referida possibilidade tributária ao dispor que:

Art. 153. Compete à União instituir impostos sobre:

I - importação de produtos estrangeiros;

$\$ 1^{\circ}$ É facultado ao Poder Executivo, atendidas as condições e os limites estabelecidos em lei, alterar as alíquotas dos impostos enumerados nos incisos I, II, IV e V (BRASIL, 1988).

Outrossim, haja vista a importância e relevância do tema dos Ex-Tarifários para atendimento de demandas internas de bens e tecnologias que náo são produzidas no país, foi reforçada no Código Tributário Nacional, no que tange ao Imposto de Importação:

Art. 21. O Poder Executivo pode, nas condiçôes e nos limites estabelecidos em lei, alterar as alíquotas ou as bases de cálculo do imposto, a fim de ajustá-lo aos objetivos da política cambial e do comércio exterior (BRASIL, 1966a).

Com todo esse embasamento legal é que se legitima o Ex-Tarifário, regime especial de tributação consistente em um mecanismo para redução de custo na aquisição de bens de capital, de informática e de telecomunicação, com redução temporária do Imposto de Importação, tendo como principal requisito para fruição desse benefício a inexistência de similar nacional para o produto a ser importado, conforme já vem sendo dito. A regulamentação mais específica que se tem para o referido benefício encontra-se na Resolução n. 66, de 14 de agosto de 2014, editada pela CAMEX (BRASIL, 2014). Os bens que serão beneficiados com o regime devem ser previstos por Resolução editada pelo referido órgão público.

Via de regra, os efeitos da Resolução CAMEX que formaliza a concessão ou renovação do Ex-Tarifário dar-se-iam apenas após sua publicação, devendo ser observadas as NCMs envolvidas no pleito e as respectivas descriçóes dos bens. Ocorre que, a dinamicidade do comércio exterior atualmente contraposta à burocracia e à morosidade na análise de tais pleitos propostos perante o MDIC, leva a se requerer o reconhecimento em caráter meramente declaratório na Resolução CAMEX que venha a publicar o Ex-Tarifário. Outrossim, em decorrência desse 
caráter declaratório de sua publicação, vem o Judiciário entendendo que tendo sido protocolado o pedido, de forma completa e atendendo-se todos os requisitos legais, ainda que não se tenha a publicação do referido benefício fiscal, o mesmo já poderá produzir efeito sobre um processo de importação que esteja em curso. Não se trata aqui de antecipação dos efeitos do Ex-Tarifário, mas do reconhecimento de que, atendidas as condiçôes previstas na legislação, notadamente a inexistência do similar nacional, o direito ao Ex-Tarifário já está assegurado, pois constituído. Subsuma-se o fato à norma. Daí, pode-se registrar a DI, concretizando o fato gerador, já com a exceção tributária sendo aplicada, reconhecendo-se a sua publicação o efeito declaratório e não constitutivo, a fim de que o Ex-Tarifário não perca sua efetividade e real finalidade, que os efeitos da redução da alíquota do II sejam estendidos ao momento anterior de seu fato gerador.

Tal extensão de efeitos não pode, em nenhum momento, ser confundida com a retroatividade de decisão a ser proferida pelo Poder Judiciário. Isso pois, a extensão dos efeitos nada mais é do que o reconhecimento de um direito já existente que, por ato de omissão da Administração Pública, mostra-se com seu exercício prejudicado pelo importador. A retroatividade, ou efeito ex-tunc, por outro lado, configurar-se-ia no caso de o reconhecimento do direito táo somente a partir da sentença, o que não permitiria refletir às Declaraçóes de Importação registradas com a alíquota minorada pela expectativa de direito gerada em razáo do cumprimento dos requisitos para concessão do Ex-Tarifário. A jurisprudência já se manifestou nesse sentido:

TRIBUTÁRIO E ADUANEIRO. IMPOSTO DE IMPORTAÇÃO. BENEFÍCIO EX-TARIFÁRIO. RESOLUÇÃO CAMEX PUBLICADA APÓS O DESEMBARQUE DAS MERCADORIAS. EFEITOS EXTENSIVOS. 1. A Resolução CAMEX não possui efeito retroativo, mas declaratório de uma situação fática constituída anteriormente a sua edição, sendo seus efeitos extensivos (não retroativos) à data de apresentação das mercadorias para desembaraço aduaneiro, ocorrida com a apresentaçáo da DI. 2. Somente haveria irretroatividade da portaria concessória do benefício se, após importação da mercadoria sobre a qual se pretendesse a reduçáo tarifária, ingressasse o importador com o pedido, pretendendo que o seu deferimento também alcançasse anterior importação, o que não é o caso dos autos (TRF4 5000711-71.2011.4.04.7214, PRIMEIRA TURMA, Relator JOEL ILAN PACIORNIK, juntado aos autos em 02/08/2012) (TRF-4, 2015). 
Fatalmente, tal fundamentação em muito se sustenta no que prevê o Regulamento Aduaneiro, em seu art. 100, quando consigna a possibilidade de que se restitua ao importador, total, ou parcialmente, o imposto pago indevidamente se, à época do fato gerador do tributo pago era beneficiário de isenção ou de redução concedida em caráter geral, como é o caso do Ex-Tarifário, ou “já havia preenchido as condiçôes e os requisitos exigíveis para a concessão de isenção ou de redução de caráter especial”. No caso da extensão dos efeitos que se trata nesse trabalho, é exatamente a situação do importador.

Havendo a referida previsão legal, aplicando a determinação normativa em consonância aos princípios da celeridade e economia processual, faz ainda mais sentido o pleito de extensão dos efeitos da Resoluçáo CAMEX a ser publicada, ainda em caráter liminar e sem a necessidade de depósito de valores. É que, caso contrário, será necessário intentar uma nova ação para que se consiga a restituição dos tributos pagos a maior que, no momento da importação, já claramente se mostram indevidos.

\section{Soluçáo prática e o posicionamento dos Tribunais Superiores sobre a extensáo dos efeitos da publicaçáo da Resoluçáo CAMEX}

Conforme vem sendo abordado neste estudo, o problema aqui proposto para debate cinge-se na seguinte situação: o importador, claramente cumprindo todos os requisitos preestabelecidos para ser um beneficiário de Ex-Tarifários e, assim, gozar de redução de alíquota do I.I. para seu produto a ser importado, não exerce tal direito em virtude da morosidade encontrada nos trâmites administrativos para a publicação da final Resolução que formaliza esse benefício fiscal. Com isso em mente, foram várias as açóes intentadas perante o Poder Judiciário nos últimos anos que, conforme a fundamentação supraexposta, buscaram a extensão dos efeitos das referidas resoluçóes a tempo pretérito, de tal maneira a atingir todas as declaraçôes de importaçấo registradas desde o pleito formal junto ao Poder Executivo no que diz respeito a concessão, ou renovação, do Ex-Tarifário para determinada NCM.

Para tanto, é de se analisar, primeiramente, a discussáo sobre a natureza da ação judicial a ser proposta e que impulsionará nosso Judiciário a decidir. Nesse particular, entende-se que, pela natureza do pedido a ser formulado, ou seja, declaraçáo do direito do importador de realizar o desembaraço da mercadoria importada com a aplicação da alíquota reduzida, entendemos que a Ação Declaratória é a que mais se enquadra. Não obstante, e muito em razáo, a uma, da urgência que 
paira sobre demandas desse tipo e, a duas, da morosidade que acompanha nosso Poder Judiciário, é fundamental que se deduza um pedido de antecipaçáo dos efeitos da tutela que, por seu turno, deve observar alguns pressupostos processuais específicos para que seja concedido.

Nesse sentido, prevê o art. 300 do Novo Código Processual Civil que para a concessão da antecipação da tutela, devem-se mostrar presentes a verossimilhança do direito invocado e, ainda, o perigo da demora e os danos que a morosidade de uma decisão final de mérito poderia ocasionar.

Para a verossimilhança, com base nos dispositivos legais já mencionados no estudo e, ainda, com fulcro na mais atual jurisprudência, inclusive dos Tribunais Superiores - conforme veremos adiante, impossível questionar a presença do direito deduzido acerca do benefício fiscal.

A mesma sorte se encontra se analisado os prejuízos que poderão ser causados em eventual não concessão da tutela antecipada supramencionada. Isso pois, pensando em uma diferença de alíquota de, via de regra, $12 \%$ (doze por cento), entre aquela ad valorem ordinariamente prevista na TEC e aquela cujo benefício fiscal permitiria, é de grande monta a diferença a ser paga a maior pelo importador. Ademais, por força das normas relativas ao IPI vinculado à importação e ao ICMS - importação, quanto maior o II a ser pago, o valor devido por esses outros tributos serão majorados, eis que o último integra a base de cálculo dos dois primeiros.

Assim, não há muito o que se questionar, sendo fundamental, para tanto, um vasto conjunto probatório que demonstre, por exemplo, que o pleito da concessão, ou de renovação, do Ex. se deu em momento pretérito ao embarque da mercadoria do Brasil. Esse ponto é um dos quais se apegam os julgadores para quando da análise de casos dessa natureza.

Dito isso, cumpre-nos observar a forma como vem se manifestando nossa jurisprudência em casos dessa natureza. Para tanto, preferimos nos ater, principalmente, aos julgados do Superior Tribunal de Justiça que, recentemente, prolatou muito bem fundamentadas decisões sobre o tema, sempre corroborando que os importadores não podem ser prejudicados pela morosidade do Poder Executivo em formalizar um benefício fiscal que, no momento do fato gerador do tributo a ele atrelado, já faziam jus.

Vejamos, por exemplo, a ementa a seguir colacionada, cujo conteúdo deu ensejo ao início da uniformização de entendimento no STJ no sentido de que a publicação da Resolução CAMEX contendo um Ex-Tarifário, na verdade, tem efeito meramente declaratório desse direito, devendo ter seus efeitos estendidos às Declaraçôes de Importação registradas após o protocolo de seu pedido: 
TRIBUTÁRIO. RECURSO ESPECIAL. IMPOSTO DE IMPORTAÇÃO. CONCESSÃO DE “EX-TARIFÁRIO”. MERCADORIA SEM SIMILAR NACIONAL. PEDIDO DE REDUÇÃO DE ALÍQUOTA. RECONHECIMENTO POSTERIOR DO BENEFÍCIO FISCAL. MORA DA ADMINISTRAÇÃO. PRINCÍPIO DA RAZOABILIDADE. APLICAÇÃO. RECURSO ESPECIAL CONHECIDO E PROVIDO. SENTENÇA RESTABELECIDA.

1. A concessão do benefício fiscal denominado "ex-tarifário" consiste na isenção ou redução de alíquota do imposto de importação, a critério da administração fazendária, para o produto desprovido de similar nacional, sob a condiçâo de comprovação dos requisitos pertinentes.

2. "O princípio da razoabilidade é uma norma a ser empregada pelo Poder Judiciário, a fim de permitir uma maior valoração dos atos expedidos pelo Poder Público, analisando-se a compatibilidade com o sistema de valores da Constituição e do ordenamento jurídico, sempre se pautando pela noção de Direito justo, ou justiça" (CALCINI, Fábio Pallaretti. O princípio da razoabilidade: um limite à discricionariedade administrativa. Campinas: Millennium Editora, 2003).

3. A injustificada demora da Administração na análise do pedido de concessão de "ex-tarifário", somente concluída mediante expediçấo da portaria correspondente logo após a internaçăo do bem, não pode prejudicar o contribuinte que atuou com prudente antecedência, devendo ser assegurada, em consequência, a redução de alíquota do imposto de importação, nos termos da legislação de regência.

4. A concessão do "ex-tarifário" equivale à uma espécie de isenção parcial. Em consequência, sobressai o caráter declaratório do pronunciamento da Administração. Com efeito, se o produto importado não contava com similar nacional desde a época do requerimento do contribuinte, que cumpriu os requisitos legais para a concessão do benefício fiscal, conforme preconiza o art. 179, caput, do CTN, deve lhe ser assegurada a reduçáo do imposto de importaçáo, mormente quando a internação do produto estrangeiro ocorre antes da superveniência do ato formal de reconhecimento por demora decorrente de questóes meramente burocráticas. 
5. Recurso especial conhecido e provido. Sentença restabelecida.

(REsp 1174811/SP, Rel. Ministro ARNALDO ESTEVES LIMA, PRIMEIRA TURMA, julgado em 18/02/2014, DJe 28/02/2014) (STJ, 2014).

Nesse mesmo sentido, em julgamento mais recente, a Ministra Regina Helena Costa, notadamente reconhecida tributarista, inclusive com diversas obras publicadas sobre a matéria, externou entendimento semelhante, ao dizer que "apesar do benefício fiscal não ter efeito retroativo, pode ser estendido ao momento do desembaraço aduaneiro quando o pedido inicial foi apresentado antes da importação do bem" e adiante completou dizendo:

A jurisprudência desta Corte é no sentido de que o atraso injustificado do exame do pedido de concessão de "ex-tarifário" concluída mediante publicaçâo de norma infralegal (no caso, Resolução n. 61 da CAMEX) após a importação do bem, não pode prejudicar o contribuinte que atuou com a devida antecedência, o que garante, consequentemente, a redução da alíquota do imposto de importação (STJ, 2017).

Também em julgado recente, a Primeira Turma do Superior Tribunal de Justiça novamente se manifestou, mantendo o entendimento anteriormente embasado e externado pelo Relator à época, Min. Arnaldo Esteves Lima, conforme supracolacionado. Nesses julgamentos, foram analisados exatamente os pontos abordados neste trabalho, ou seja, a impossibilidade de se gerar ônus ao importador em virtude de uma morosidade que afeta o Poder Público e seus servidores e, ainda, a necessidade de dar à Resolução CAMEX publicada após configurado o fato gerador do Imposto de Importação uma natureza meramente declaratória, ou seja, um simples reconhecimento de situação fática constituída anteriormente a sua edição, sendo seus efeitos extensivos às declaraçôes de importaçấo registradas após a formalização do pleito para concessão do Ex-Tarifário a determinada NCM. A propósito:

TRIBUTÁRIO E PROCESSUAL CIVIL. RECURSO ESPECIAL. ART. 1.022, II, DO CÓDIGO DE PROCESSO CIVIL DE 2015. INEXISTÊNCIA DE VIOLAÇÃO. IMPOSTO DE IMPORTAÇÃO. ARTS. 105 E 144 DO CÓDIGO TRIBUTÁRIO NACIONAL. ART. 23 DO DECRETO-LEI N. 37/1966. REDUÇÃO DE ALÍQUOTA POR RESOLUÇÃO POSTERIOR À APRESENTAÇÃO PARA DESPACHO ADUANEIRO. EXTENSÃO DOS EFEITOS ÀQUELA DATA. CABIMENTO. 
1. É deficiente a fundamentação do recurso especial em que a alegação de ofensa ao art. 1.022 do CPC/2015 se faz de forma genérica, sem a demonstração exata dos pontos nos quais o acórdão incorreu em omissão, contradição ou obscuridade. Aplica-se à hipótese o óbice da Súmula 284 do STF.

2. O fato gerador do Imposto de Importação materializa-se no ato em que se apresenta a declaraçấo de importaçâo, o qual, por sua vez, dispara o procedimento denominado despacho aduaneiro. É o que se depreende da leitura dos arts. 19 do CTN, c/c o art. $1^{\circ}$ do Decreto-Lei n. 37/1966, 72 e 73, I, do Decreto n. $6.759 / 2009$.

3. Considerando que a obrigação tributária se rege pela lei vigente à data da ocorrência do fato gerador, conforme interpretação sistemática dos arts. 105 e 144 do CTN, eventuais benefícios tributários, salvo normativo em sentido contrário, devem ser aplicados a fatos geradores futuros ou pendentes, o que, em tese, afastaria a pretensão formulada na inicial do mandado de segurança que deu origem ao presente recurso especial.

4. No entanto, há de se considerar que, neste caso, embora a declaração de importação tenha sido apresentada em momento anterior à resolução da CAMEX que deu destaque tarifário "ex." para o bem importado, o pedido de concessão desse benefício foi postulado em data pretérita ao protocolo da declaração de importação (fato gerador).

5. Em hipótese como a dos autos, é razoável e proporcional que à impetrante sejam garantidos os benefícios do regime "Ex-Tarifário", uma vez que os havia requerido à autoridade competente antes mesmo da ocorrência do fato gerador.

6. Registre-se que tal compreensão em nada contraria os dispositivos do Código Tributário Nacional suscitados pela recorrente. Ao contrário, confere-lhes prestígio, pois, na data da ocorrência do fato gerador, havia situação intrinsecamente relacionada a elemento da obrigação tributária - notadamente, o quantitativo: alíquota - referente ao Imposto de Importaçáo que se encontrava pendente de análise pela administração tributária.

7. Recurso especial conhecido em parte e, nessa extensão, não provido.

(REsp 1664778/PR, Rel. Ministro OG FERNANDES, SEGUNDA TURMA, julgado em 20/06/2017, DJe 26/06/2017) (STJ, 2018). 
Fica claro, assim, que não há fundamentos para o Fisco realizar a cobrança do tributo com a alíquota normal nos casos em que, no momento do fato gerador do imposto de importação, ou seja, no registro da declaração de importação, o importador já fizer jus ao destaque tarifário do "ex.", pelo cumprimento de todos os seus requisitos, configurando empecilho único a publicação de Resolução CAMEX que declare tal fato. Isso porque, se assim se permitir, haverá uma clara afronta aos princípios constitucionalmente previstos como, por exemplo, o da livre iniciativa e o da não intervenção estatal na economia ou nas relaçôes comerciais.

É de se ressaltar: não pode o importador, fomentador do desenvolvimento nacional a partir da importação de novas tecnologias e recursos, ser prejudicado pela inércia da Administração Pública. A possibilidade de extensão dos efeitos da decisão encontra amparo na legislação vigente e em sua melhor interpretação e aplicação, tendo em vista diversos dispositivos legais já mencionados. Ademais, é de se considerar que a questão já passou pelo crivo do Tribunal da Cidadania, o Egrégio Superior Tribunal de Justiça, responsável por julgar a aplicação da legislação federal. Nesse sentido, o Egrégio Tribunal Cidadão, de maneira uníssona, por sua Primeira e Segunda Turma, vem decidindo casos como esse de maneira favorável ao importador, sempre com o fulcro na melhor interpretação e aplicação da legislação federal e de molde a não prejudicar a atividade empresária, já tão onerosa, mormente evitando que a insuficiência na prestação eficiente de serviço público pelo Poder Executivo o prejudique ainda mais. Com tal posicionamento do Egrégio Superior Tribunal de Justiça evita também seja afrontado o que prevê o art. 37 de nossa Constituição Federal que determina que "administração pública direta e indireta de qualquer dos Poderes da União, dos Estados, do Distrito Federal e dos Municípios obedecerá aos princípios de legalidade, impessoalidade, moralidade, publicidade e eficiência” (BRASIL, 1988).

Sendo assim, intentando o importador o pleito para concessão, ou renovação, do Ex-Tarifário desejado, caso haja mora do Poder Público Federal em analisar o pleito e publicar seu reconhecimento, havendo um conjunto probatório suficientemente robusto nesse sentido, possa haver, por parte do Judiciário, se provocado pelo interessado, o deferimento, desde logo, até mesmo da antecipação dos efeitos da tutela, desde que observados os pressupostos processuais previstos no art. 300, do Novo Código Processual Civil e já pormenorizados anteriormente nesse estudo. O provimento final, desde que o Magistrado interprete corretamente as razóes do importador e, claro, observe à jurisprudência dominante nos Tribunais Superiores, tende a ser o reconhecimento do direito do contribuinte em recolher o imposto de importação com a isenção ou com a alíquota reduzida desde 
o momento da formalização do pleito para o benefício fiscal. Em resumo, o reconhecimento do efeito meramente declaratório da Resoluçáo CAMEX que torna formal a redução da alíquota do II a determinada NCM será capaz de fazer com que os importadores recolham o referido tributo conforme a redução da alíquota decorrente do Ex., inclusive no que diz respeito às declaraçóes de importação registradas após a formalização do pleito e que ficaram pendente de formalização por mera demora do Poder Público.

\section{Conclusão}

Assim sendo, é importante concluir fazendo uma análise em conjunto de tudo o que foi supraexposto, haja vista que, apenas assim, criando uma linha de raciocínio consistente, é que se pode chegar ao resultado final pretendido, qual seja, sustentar com embasamento o entendimento de que a publicação da Resolução CAMEX que formaliza a concessão, ou renovação, do benefício de Ex-Tarifário tem efeito meramente declaratório, ou seja, apenas ratifica situação fática pretérita que já constituía direito do importador, de tal maneira a permitir a extensão dos efeitos da redução de alíquota a todas as declarações de importação registradas desde a formalização do pleito.

Ora, se analisarmos desde a motivação da criação do Ex-Tarifário, em 1990, e também as características peculiares do imposto de importação, principalmente sua extrafiscalidade, poderemos entender que, na verdade, tal benefício fiscal é um termômetro para o comércio internacional de BK (bem de capital) e BIT (bens de informática e de telecomunicaçóes). Isso pois, a partir da concessão, ou não, da reduçáo de alíquotas para bens dessa natureza, o Poder Executivo consegue controlar, fomentando, estimulando ou, se for o caso, freando a comercialização de produtos desse tipo.

A grande questão é que, em muitas oportunidades, o importador, apesar de cumprir todos os requisitos legais estabelecidos pela Resolução CAMEX n. 66/2014, em virtude única e exclusivamente da morosidade na atuaçáo do Poder Executivo, vê-se prejudicado para concretizar sua operação de importação com o recolhimento do imposto de importação menor, contando com a redução da alíquota decorrente do destaque à tarifária normal. A partir daí, o STJ firmou entendimento que, na verdade, não pode tal ônus ser suportado pelo importador, tendo em mente, inclusive, o importante papel que esse tem no desenvolvimento nacional através da importação de novas tecnologias para o País.

Dessa feita, ficou sedimentado o entendimento de que o atraso injustificado por parte da Administraçáo Pública, quando da análise do pleito de concessão, ou renovaçáo, do Ex. não pode ter o condão de impossibilitar ao importador o gozo 
de benefício fiscal que, no momento do fato gerador do tributo ao qual é atrelado, já faz jus. Sob esse prisma é que se defende e se reconhece jurisprudencialmente a extensão dos efeitos da Resolução CAMEX aos fatos geradores que ocorram após o protocolo do pedido, porém antes de sua publicação. Em outras palavras, que se produza o efeito do Ex-Tarifário às declarações de importação registradas após seu pleito, ainda que à época não tenha sido publicado o ato formal do referido benefício.

\section{Referências}

ATAliBA, G. Bitributação. Revista da Faculdade de Direito da Universidade Federal de Minas Gerais, Belo Horizonte, n. 6, p. 159-169, out. 1966.

BRASIL. Presidência da República. Casa Civil. Subchefia para Assuntos Jurídicos. Lei n. 3.224, de 14 de agosto de 1957. Dispóe sobre a Reforma da Tarifa das Alfândegas, e dá outras providências. Brasília, DF: Presidência da República, 1957. Disponível em: <http://www.planalto.gov.br/ccivil_03/leis/L3244.htm>. Acesso em: 23 out. 2017.

BRASIL. Presidência da República. Casa Civil. Subchefia para Assuntos Jurídicos. Lei n. 5.172, de 25 de outubro de 1966. Dispóe sobre o Sistema Tributário Nacional e institui normas gerais de direito tributário aplicáveis à União, Estados e Municípios. Brasília, DF: Presidência da República, 1966a. Disponível em: <http://www.planalto.gov.br/ccivil_03/Leis/L5172.htm>. Acesso em: 26 jun. 2018.

BRASIL. Presidência da República. Casa Civil. Subchefia para Assuntos Jurídicos. Decreto-Lei n. 37, de 18 de novembro de 1966. Dispóe sobre o imposto de importação, reorganiza os serviços aduaneiros e dá outras providências. Brasília, DF: Presidência da República, 1966b. Disponível em: <http://www.planalto.gov. br/ccivil_03/decreto-lei/Del0037.htm>. Acesso em: 6 dez. 2017.

BRASIL. Presidência da República. Casa Civil. Subchefia para Assuntos Jurídicos. Constituição da República Federativa do Brasil de 1988. Brasília, DF: Presidência da República, 1988. Disponível em: <http://www.planalto.gov.br/ccivil_03/ constituicao/constituicao.htm>. Acesso em: 6 dez. 2017.

BRASIL. Ministério da Economia, Indústria, Comércio Exterior e Serviços. Acordo sobre a implementação do artigo VII do Acordo Geral sobre Tarifas e Comércio 1994. Brasília, DF: MDIC, 1994. Disponível em: <http://www.mdic.gov.br/ arquivos/dwnl_1196685851.doc>. Acesso em: 16 ago. 2019. 
BRASIL. Presidência da República. Casa Civil. Subchefia para Assuntos Jurídicos. Decreto $n$. 6759, de 5 de fevereiro de 2009. Regulamenta a administração das atividades aduaneiras, e a fiscalização, o controle e a tributação das operaçôes de comércio exterior. Brasília, DF: Presidência da República, 2009. Disponível em: <http://www.planalto.gov.br/ccivil_03/_ato2007-2010/2009/decreto/d6759. htm>. Acesso em: 6 dez. 2017.

BRASIL. Ministério da Economia. Secretaria-Executiva de Comércio Exterior CAMEX. Resolução CAMEX n. 66, de 6 de agosto de 2014. Dispóe sobre a redução, temporária e excepcional, da alíquota do Imposto de Importação, por meio do Regime de Ex-Tarifário, para bens de capital (BK) e bens de informática e de telecomunicações (BIT) sem produção nacional equivalente, e estabelece regras procedimentais. Brasília, DF: CAMEX, 2014. Disponível em: <http://www. camex.gov.br/component/content/article?id=1380>. Acesso em: 26 jun. 2016.

BRASIL. Ministério da Economia, Indústria, Comércio Exterior e Serviços. Base de dados do Comex Stat. Brasília, DF: MDIC, 2018a. Disponível em: <http:// www.mdic.gov.br/comercio-exterior/estatisticas-de-comercio-exterior/base-dedados-do-comercio-exterior-brasileiro-arquivos-para-download>. Acesso em: 5 jun. 2018.

BRASIL. Ministério da Economia, Indústria, Comércio Exterior e Serviços. Quem analisa e quais os critérios? Brasília, DF: MDIC, 2018b. Disponível em: <http:// www.mdic.gov.br/index.php/competitividade-industrial/acoes-e-programas-13/ o-que-e-o-ex-tarifario-2/fluxos-e-prazos-3>. Acesso em: 5 jun. 2018.

BRASIL. Ministério da Economia, Indústria, Comércio Exterior e Serviços. O que é o Ex-Tarifário. Brasília, DF: MDIC, 2019. Disponível em: <http://www.mdic. gov.br/competitividade-industrial/acoes-e-programas-13/o-que-e-o-ex-tarifario > Acesso em: 16 ago. 2019.

DALSTON, C. O. Exceçôes tarifárias: Ex-Tarifário do Imposto de Importação. São Paulo: Aduaneiras, 2005.

KEEDI, S. $A B C$ do comércio exterior: abrindo as primeiras páginas. São Paulo: Aduaneiras, 2016.

PAULSEN, L.; MELO, J. E. S. Impostos federais, estaduais e municipais. Porto Alegre: Livraria do Advogado, 2015.

PIANI, G.; MIRANDA, P. Regimes especiais de importação e "Ex-Tarifários": o caso do Brasil. Rio de Janeiro: IPEA, 2006. Disponível em: <http://repositorio.ipea. gov.br/bitstream/11058/2190/1/TD_1249.pdf>. Acesso em: 26 jun. 2018. 
SABBAG, E. Manual de Direito Tributário. 8. ed. São Paulo: Saraiva, 2016.

STJ - SUPREMO TRIBUNAL DE JUSTIÇA. Recurso Especial: 1174811/SP,

Rel. Ministro Arnaldo Esteves Lima, primeira turma, julgado em 18/02/2014, DJe 28/02/2014. JusBrasil, 2014. Disponível em: <https://stj.jusbrasil.com.br/ jurisprudencia/24976167/recurso-especial-resp-1174811-sp-2010-0005931-0stj/relatorio-e-voto-24976169?ref=serp >. Acesso em: 20 jun. 2018.

STJ - SUPREMO TRIBUNAL DE JUSTIÇA. Recurso Especial: 1.688.564-RS, Rel. Regina Helena Costa. Data de Publicação: DJ 09/11/2017. JusBrasil, 2017. Disponível em: <https://stj.jusbrasil.com.br/jurisprudencia/519086614/recursoespecial-resp-1688564-rs-2017-0184857-9?ref=serp>. Acesso em: 20 jun. 2018.

STJ - SUPREMO TRIBUNAL DE JUSTIÇA. Recurso Especial: 1664778/ PR, Rel. Ministro OG FERNANDES. SEGUNDA TURMA, julgado em 20/06/2017, DJe 26/06/2017. JusBrasil, 2018. Disponível em: <https://stj. jusbrasil.com.br/jurisprudencia/559881730/agravo-interno-no-recurso-especialagint-no-resp-1707483-rs-2017-0285958-1?ref=serp>. Acesso em: 20 jun. 2018.

TRF-4 - TRIBUNAL REGIONAL FEDERAL DA 4a REGIÃO. Apelação Cível: 5000711-71.2011.4.04.7214, primeira turma, Relator Des. Fed. Joel Ilan Paciornik, juntado aos autos em 02/08/2012. JusBrasil, 2015. Disponível em: <https://trf-4.jusbrasil.com.br/jurisprudencia/433649042/apelacao-remessanecessaria-apl-50012163220154047114-rs-5001216-3220154047114/inteiroteor-433649081?ref=serp>. Acesso em: 26 de jun. 2018. 


\title{
ANÁLISE DA ARGUIÇÃO DE DESCUMPRIMENTO DE PRECEITO FUNDAMENTAL - ADPF - 186 Ã LUZ DA HERMENÊUTICA FENOMENOLÓGICA E DO ATIVISMO JUDICIAL ${ }^{1}$
}

\author{
Luana Paixão Dantas do Rosário ${ }^{2}$ \\ Universidade Estadual de Santa Cruz (UESC) \\ Fernando Leal Menezes ${ }^{3}$ \\ Universidade Estadual de Santa Cruz (UESC) \\ Artigo recebido em: 15/09/2019. \\ Artigo aceito em: 18/09/2019.
}

\section{Resumo}

Com o objetivo de analisar o julgamento da Arguição de Descumprimento de Preceito Fundamental (ADPF) n. 186, a fim de traçar o seu perfil epistemológico, o presente trabalho parte da hipótese de que, à luz da hermenêutica fenomenológica e do ativismo judicial, o julgamento nessa ADPF foi hermeneuticamente ativista. Para tanto, traz à abordagem a compreensão da hermenêutica fenomenológica, com fundamento em Heidegger e Gadamer - na medida em que apresenta o julgamento como uma possibilidade de verdade que se desvela por meio de um processo que se dá entre o texto e o intérprete -, bem como a concepçáo do ativismo judicial com base em Garapon e Dworkin, demonstrando como se efetiva a postura ativa do juiz no âmbito da efetivaçáo dos preceitos fundamentais. O método empregado foi o hermenêutico fenomenológico. A técnica empregada foi a pesquisa documental e bibliográfica.

1 Este trabalho resulta das pesquisas realizadas ao longo de um ano de pesquisa na Iniciação Científica, como pesquisador voluntário - na esfera do plano de trabalho "análise teórico-epistemológica" do julgamento da Arguição de Descumprimento de Preceito Fundamental - ADPF - 186 (cotas raciais) no âmbito do projeto "Jurisdição Constitucional e Democracia: uma análise hermenêutica da ADPF à luz do ativismo judicial", do Grupo de Pesquisa em Jurisdição Constitucional, Hermenêutica e Democracia - JCHD

2 Doutora e Mestre em Direito Público pela Universidade Federal da Bahia (UFBA). Professora de Direito Constitucional na UESC. Editora da Diké. Líder do Grupo de Pesquisa Jurisdição Constitucional, Democracia e Hermenêutica JCHD/DgpCNPq. ORCID: https://orcid.org/0000-0001-6276-8697 / e-mail: lpdrosario@uesc.br 3 Bacharel em Direito pela UESC. Pesquisador no Grupo de Pesquisa Jurisdição Constitucional, Democracia e Hermenêutica JCHD/DgpCNPq. E-mail: flealmenezes@gmail.com 
Conclui-se que, conquanto não haja referência expressa, é possível identificar no julgamento da ADPF 186 a influência da hermenêutica heidegger-gadameriana e do ativismo hermenêutico Dworkin/Garapon, e que é possível a aproximação epistemológica dos referidos marcos teóricos, para que se proponha o ativismo hermenêutico fenomenológico.

Palavras-chave: ADPF 186; ativismo

\section{ANALYSIS OF THE CLAIMS OF NON- COMPLIANCE WITH FUNDAMENTAL PRECEPT - ADPF - 186 IN THE LIGHT OF THE PHENOMENA HERMENEUTIC AND JUDICIAL ACTIVISM}

\section{Abstract}

With the intent of analyzing the judgement of Claims of Non-compliance With a Fundamental Precept (ADPF) $n$. 186, in order to trace it's epistemological profile, the current work starts from the hypothesis that it's possible to analyze it's judgement under the judicial activism and phenomenological hermeneutics light. Therefore, it brings to it's approach the phenomenological hermeneutics way of understanding, based on Heidegger and Gadamer - so far as it introduces the judgement as a possibility of truth that unveils itself in a process between the text and it's interpreter-, as well as the conception of judicial activism presented by Garapon and Dworkin, demonstrating how it consolidates the judge's active stance in the field of fundamental precept's consolidation. The method used will be the hermeneutics, the research technique will be bibliographic and documental. Concludes that, as long as there's no explicit reference, it's possible to identify in the ADPF 186's judgement the influence of heidegger-gadamerian hermeneutics and the Dworkin/Garapon hemeneutic activism, and that the epistemological approach of the referred theoretical frameworks is possible, with the intent to propose the phenomenological hermeneutic activism.

Keywords: ADPF 186; judicial activism; phenomenological hermeneutics. 


\section{Introdução}

O Poder Judiciário, mormente a Jurisdição Constitucional, tem experimentado um fenômeno cada vez mais sensível a uma análise atenta: a ascensão da autoridade judiciária. O processo judicial assume um espaço simbólico e torna-se o instrumento por meio do qual é viável a exigência pela efetivação do pacto democrático. Por isso, cada vez mais, os juízes são chamados a se pronunciar sobre casos que exigem uma atividade interpretativa complexa e inovadora - não arbitrária, porém. É nesse contexto que surgem as discussões concernentes à busca pela justificativa para o comportamento do julgador/intérprete, naqueles casos que trazem o questionamento em relação à originalidade da decisão e o respeito ao que está insculpido no texto normativo, que serâo objetos de análise neste artigo.

Desse modo, o presente artigo pretende analisar o julgamento da ADPF n. 186 à luz do marco teórico do ativismo judicial e da hermenêutica fenomenológica. O problema que se coloca a essa pesquisa é perquirir qual o perfil teórico epistemológico do julgamento da ADPF n. 186 à luz do marco teórico do ativismo judicial de Antoine Garapon e Ronald Dworkin (ainda que esses dois autores não se considerem, necessariamente, representantes do que se tem denominado ativismo - sobre o qual nos deteremos adiante) e da hermenêutica de matriz fenomenológica de Heidegger/Gadamer.

A hipótese de trabalho foi que a análise hermenêutica e do discurso do ministro relator e daqueles que o seguiram na decisão plenária expressam forte influência filosófica do ativismo judicial hermenêutico de Dworkin/Garapon e da hermenêutica de Gadamer, de matriz heideggeriana. O método empregado, em sentido amplo e epistemológico, foi o hermenêutico fenomenológico. A técnica empregada foi a pesquisa documental, em análise qualitativa do julgamento mencionado, em consulta aos autos disponíveis no site do Supremo Tribunal Federal e a pesquisa bibliográfica na consulta ao marco teórico selecionado.

Para alcançar as metas traçadas, a pesquisa parte do delineamento das ações afirmativas, que estabelecem meios correcionais ou mitigadores dos efeitos deixados em sociedades cujos ordenamentos jurídicos permitiram, no passado, a discriminação racial como fonte de injustiças, visando à efetivação das garantias fundamentais trazidas pela Constituição. Dar-se-á seguimento pela demonstração do objeto discutido na ADPF 186, qual seja, o sistema de reserva de vagas com base no critério étnico-racial (cotas raciais). A partir de então, segue-se pelas obras de Heidegger e Gadamer, para discorrer a respeito da hermenêutica fenomenológica, além de apreciar o ativismo judicial de Garapon (ressaltando desde já a sua posição crítica ao ativismo) e Dworkin (embora ele náo se admita enquanto tal), a fim 
de propor o ativismo hermenêutico fenomenológico, como método de análise epistemológica, e de traçar o perfil teórico epistemológico do julgamento da ADPF 186.

A pesquisa tem pertinência teórica e social porquanto a ADPF constitui um instrumento original do sistema de controle de constitucionalidade brasileiro, originalidade reconhecida pela diversidade de constitucionalistas pátrios, a exemplo de Dirley da Cunha Júnior (2016) e Gabriel Dias Marques da Cruz (2011), de suma importância na discussão de temas que atingem a comunidade política.

\section{Políticas de açóes afirmativas}

As açóes afirmativas, conhecidas por realizar uma distinção no presente para reparar uma discriminação do passado, que produziu uma injustiça que alcança o presente, são uma espécie de política pública. Segundo Hofling (2001), políticas públicas, sob a perspectiva social, traduzem ações que determinam o padrão de proteção social implantado pelo Estado, que visam à redistribuição dos benefícios sociais com intuito de diminuir as desigualdades estruturais produzidas pelo desenvolvimento socioeconômico. Bucci (2006) elucida que são um conjunto de processos de planejamento de governo e orçamentário, juridicamente regulamentados, que objetivam coordenar os meios à disposição do Estado e as atividades privadas, para a realizaçáo de objetivos socialmente relevantes e politicamente determinados. Hofling (2001, p. 31) arremata "é o Estado implantando um programa de governo, através de programas, de açóes voltadas para setores específicos da sociedade".

Entre essas açóes estão as chamadas políticas de açóes afirmativas, que, de acordo com Gomes e Silva (2002), podem ser definidas como um conjunto de políticas públicas e privadas - compulsórias, facultativas ou voluntárias concebidas com o objetivo de combate a discriminaçóes, como a racial, bem como para corrigir ou mitigar os efeitos presentes da discriminação praticada no passado, com vistas à concretização do ideal de efetiva igualdade de acesso a bens fundamentais como a educação e o emprego. As políticas afirmativas privadas ganham relevo em razão da eficácia horizontal ${ }^{4}$, explicação de tal locução, ao menos, em nota de rodapé dos Diretos Fundamentais, mas fogem ao recorte deste trabalho, que se referirá às políticas públicas de açôes afirmativas, especificamente,

4 A eficácia horizontal dos Direitos Fundamentais representa o fenômeno da sua incidência no âmbito das relações privadas. Nas palavras de Sarlet (2012, p. 9), "cuida, principalmente, de uma interpretação conforme a Constituição das normas de Direito Privado e da incidência da Constituição no âmbito das relações entre sujeitos privados, seja por meio da concretização da Constituição pelos órgãos legislativos, seja pela interpretação e desenvolvimento jurisprudencial". 
adiante, sobre o sistema de reserva de vagas com base no critério étnico-racial.

Conforme Gomes e Silva (2002), as discussôes a respeito das açôes afirmativas resultam de uma superação da concepção constitucional formal e liberal acerca da igualdade; pela qual a lei, genérica e abstrata, deve ser igual para todos, sem qualquer distinção ou privilégio, exigindo do Estado a devida neutralidade na aplicação do texto normativo. Porém, as experiências, política e jurídica, têm demonstrado que a igualdade formal, tal como foi pensada pela escola liberal, não passa de uma mera ficção. Por isso é necessária a construção de uma concepção constitucional substancial da igualdade, que leve em consideração as desigualdades concretas existentes na sociedade. De sorte que as situaçóes desiguais sejam tratadas de maneira dessemelhante, evitando-se assim o aprofundamento e a perpetuação de desigualdades engendradas pela própria sociedade. Essa concepção é o fundamento basilar das políticas de ações afirmativas.

A mudança de perspectiva sobre o direito à igualdade relaciona-se à evoluçáo dos Direitos Humanos, em suas variadas dimensões. Segundo Flávia Piovesan (2005), é no contexto da especificação do sujeito de direito - em grupos que passam a ser vistos em sua especificidade e nas peculiaridades de sua condição social - que floresce o direito à diferença, traduzido no esforço do combate à discriminação. Embora, como adverte a autora, o combate à diferença não seja suficiente para alcançar a igualdade de fato, senão aliada a políticas compensatórias.

[...] como poderoso instrumento de inclusão social, situam-se as ações afirmativas. Elas constituem medidas especiais e temporárias que, buscando remediar um passado discriminatório, objetivam acelerar o processo com o alcance da igualdade substantiva por parte de grupos vulneráveis, como as minorias étnicas e raciais e as mulheres, entre outros grupos. Por meio delas transita-se da igualdade formal para a igualdade material e substantiva (PIOVESAN, 2005, p. 49).

Os Estados Unidos são exemplo de segregação racial histórica e pioneirismo na adoção das ações afirmativas. Segundo Moehlecke (2002), os anos 1960 nos Estados Unidos foram marcados por reivindicaçóes democráticas internas, expressas, principalmente, no movimento pelos direitos civis, cuja bandeira central era a extensáo da igualdade de oportunidades a todos. Foi na década de 1960 que se deu início à eliminação das leis segregacionistas, juntamente com pressôes no sentido de exigir do Estado postura ativa para melhoria das condições de vida da população negra e políticas públicas que objetivassem a superação da desigualdade dessa parte da população. 
Entre os movimentos norte-americanos que marcaram a luta pela igualdade racial, na década de 1960, Oliven (2007) destaca o movimento pelos direitos civis, liderado pelo pastor Martin Luther King Júnior, e o Black Panther Party (Partido dos Panteras Negras). Enquanto Martin Luther King Júnior pregava a não violência e a integraçáo dos negros na sociedade (embora seu movimento tenha assumido caráter mais combativo após sua morte), o Black Panther Party apoiava, para a luta pelo poder, o uso de armas por parte de negros e negras.

Segundo Johnson (2002), o Partido dos Panteras Negras foi a organização política afro-americana mais importante e radical do movimento negro nas décadas de 1960 e 1970 e surgiu como uma organização que visava contribuir efetivamente para a ascensão social, econômica e política dos negros. Na percepção dos seus fundadores, o movimento dos direitos civis havia fracassado no tratamento das necessidades das massas negras.

Um grande marco na luta pela igualdade racial ocorreu em 1954, quando a Suprema Corte Norte-Americana, no julgamento do caso Brown v. Board of Education, decidiu pela inconstitucionalidade da segregação racial praticada pelos estados federativos e pelas escolas públicas. O caso Brown v. Board of Education é um importante precedente judicial na luta pelos direitos fundamentais e na história do ativismo judicial. A segregação racial praticada em diversos serviços públicos, como transportes e escolas, não obstante a décima quarta emenda à Constituição norte-americana ${ }^{5}$ pregasse o direito à igualdade, havia encontrado respaldo nas decisôes da Suprema Corte Norte-Americana, até a decisão do caso Brown v. Board of Education.

Dworkin (2014, p. 462) analisa que parte da população acreditava ter até mesmo argumentos morais para sustentar a segregação racial como "a vontade de Deus, ou que todos tinham o direito de viver com a sua gente", que a Suprema Corte sustentou, por longo período, a tese de "separados, mas iguais" para seguir caminho interpretativo de que a segregação racial não violaria a décima quarta emenda, e que haveria argumentos de utilidade (de política), contrários à pronta erradicação judicial da segregação racial, como a falta de estrutura do sistema escolar.

Mas, conforme Dworkin, a decisão pela erradicação da segregação racial tomada no caso Brown v. Board of Education é a única decisão possivel que considera o direito em sua integridade, a realizar um direito que deve ser levado a sério, que

5 XIV Emenda à Constituição norte-americana, seção 1: "Todas as pessoas nascidas ou naturalizadas nos Estados Unidos e sujeitas a sua jurisdição são cidadãos dos Estados Unidos e do Estado onde tiver residência. Nenhum Estado poderá fazer ou executar leis restringindo os privilégios ou as imunidades dos cidadãos dos Estados Unidos, nem poderá privar qualquer pessoa de sua vida, liberdade ou bens sem o devido processo legal, ou negar a qualquer pessoa sob sua jurisdição igual proteção das leis". (Universidade Estadual de Londrina. Tradução no original, disponível em: <http://www.uel.br/pessoal/jneto/gradua/historia/recdida/ConstituicaoEUARecDidaPESSOALJNETO.pdf>. Acesso em: 25/05/2019. 
considera uma questão de princípio: a dimensão irredutível do ser humano de ser tratado como tal. A decisão que atenta ao cumprimento da igualdade. Sendo, por isso, a única decisão possivel em uma Democracia fundada na igualdade política.

Desse modo, com fundamento em Dworkin (1999), não é possível, sob nenhuma perspectiva, considerar a segregaçáo racial constitucional, mesmo que, a pretexto de se justificar essa ideia, apresente-se o argumento de que foram consideradas as preferências de uma maioria.

As açôes afirmativas surgem, pois, em países que têm a sua história marcada pela discriminação e opressão a grupos relegados à margem da sociedade. No Brasil, um país que foi escravocrata por mais de trezentos anos, a atividade econômica por muito tempo se desenvolveu à custa da máo de obra escrava, ou, após a abolição, precarizada. Desse modo, a situação do negro no país é resultado de discriminação histórica. Luciana Jaccoud (2008) afirma que a desigualdade entre brancos e negros é considerada uma das mais perversas dimensóes do tecido social no Brasil. Segundo a autora, as grandes diferenças raciais marcam quase todos os campos da vida social brasileira, conforme demonstram as divulgaçóes de indicadores econômicos, e essa diferença, que se faz presente no campo da educação e da saúde, por exemplo, gera empregos instáveis, violência ou diminuição na expectativa de vida.

Nesse ínterim, há que se ressaltar que à época da propositura da ADPF 186 (2009), consoante dados apresentados pelos arguidos, colhidos do voto do relator, ministro Lewandowski (2012), a população negra ocupava apenas $2 \%$ do contingente universitário do país, conquanto representassem $45 \%$ da população brasileira. De acordo com a Síntese de Indicadores Sociais: em uma análise das condiçóes de vida da população brasileira, divulgada em 2016, pelo Instituto Brasileiro de Geografia e Estatística (IBGE), em 2005, apenas 5,5\% dos jovens entre 18 e 24 anos, de cor preta ou parda, cursavam o nível superior. Em 2015, esse número apresentou significativo crescimento, alcançando 12,8\%. Mas, de acordo com os mesmos indicadores, esses números demonstram a diferença representativa em relação aos jovens brancos da mesma faixa etária, que, em 2005, já era de $17,8 \%$, e, em 2015, alcançou 26,5\%. Verifica-se, pois, que apesar da distância do percentual entre jovens negros (considerados pretos e pardos) e brancos na Universidade continuar alta, o crescimento percentual de jovens negros na Universidade é de extrema relevância, o que destaca, portanto, a importância das políticas públicas de açóes afirmativas. 


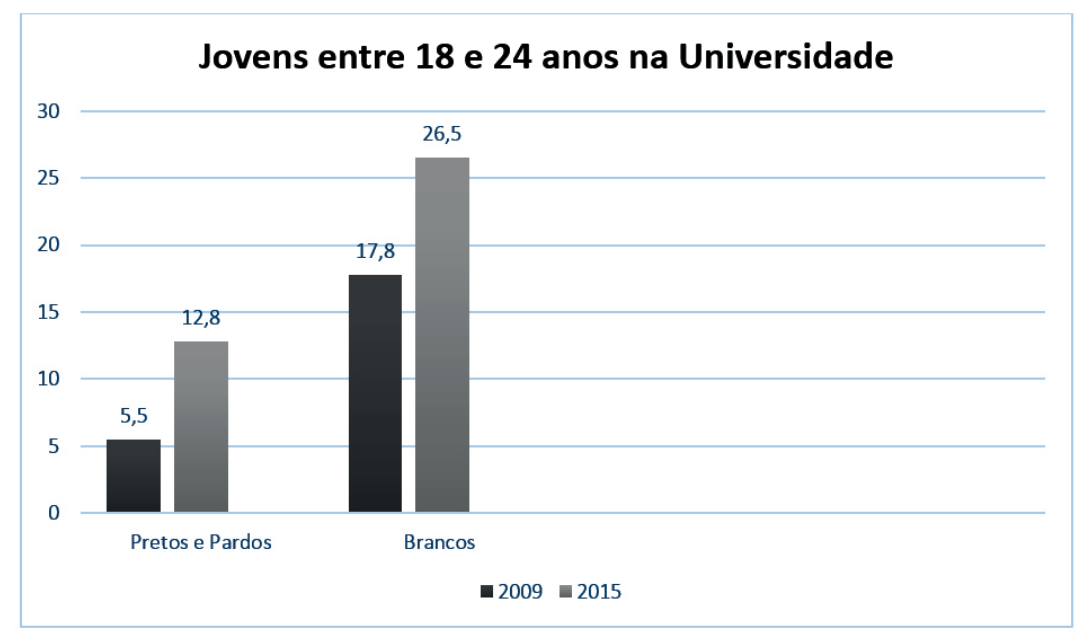

Gráfico 1: Jovens entre 18 e 24 anos na Universidade.

Fonte: elaborado pelos autores.

As mudanças desses percentuais, provocadas por força das açóes afirmativas buscam promover mudanças na realidade. Segundo Cecchin (2006), a noção de justiça compensatória/reparatória constitui um dos fundamentos das açôes afirmativas. Conforme o autor, a justiça compensatória/reparatória está relacionada a fatos históricos, com o escopo de corrigir erros do passado. As minorias, afirma Cecchin (2006), sofrem até os dias atuais os reflexos das injustiças - como a escravidão - cometidas a seus antepassados e que marcam a sociedade brasileira, tendo em vista que ainda não se instituíram instrumentos eficazes à efetiva correção das arbitrariedades praticadas contra grupos discriminados em toda nossa afirmação histórica. Por essa razão, afirma-se que as ações afirmativas, como as cotas raciais, "visam corrigir distorções do passado, reparando as atrocidades cometidas por grupos dominantes, em prejuízo dos dominados" (CECCHIN, 2006, p. 337).

Feitas, então, essas consideraçôes, segue-se à análise da ADPF 186, proposta pelo Partido Democratas, sobre as políticas de açóes afirmativas para reserva de vagas em universidades públicas brasileiras, com base e critério étnico-racial. 


\section{A arguição de descumprimento de Preceito Fundamental n. 186}

Cunha Júnior (2016) elucida que a Arguição de Descumprimento de Preceito Fundamental (ADPF) - instituto de criação do ordenamento jurídico brasileiro, introduzido pela Constituição Federal de 1988 - constitui uma ação constitucional específica que visa à proteção exclusivamente dos preceitos fundamentais, face à ameaça ou lesão resultante de qualquer ato ou omissão do poder público, destinada a provocar a jurisdição constitucional concentrada do Supremo Tribunal Federal. Ela está prevista no art. 102, $\$ 1$, que dispóe que será apreciada pelo Supremo Tribunal Federal.

O autor ressalta, porém, que, para a compreensão do instituto em comento, é preciso registrar a existência de outros institutos na legislação comparada, que podem ter servido de inspiraçáo para o legislador - constituinte e ordinário - brasileiro, conquanto a ADPF seja uma criação pátria. Elenca como exemplos, entre outros, o writ of certiorari do direito norte-americano, a popularklage do direito bávaro, o recurso de amparo do direito espanhol e o Verfassungsbeschwerde do direito alemão. Esses institutos, ainda conforme Cunha Júnior (2016), foram pensados como meio de proteção especial dos Direitos Fundamentais - demonstrando a ideia de adoçấo de parâmetro restrito de controle de constitucionalidade, que influenciou o constituinte brasileiro na criação de uma ação especial de proteção somente dos chamados preceitos fundamentais. Essa atençáo dedicada aos preceitos fundamentais, aliás, para André Ramos Tavares (2001), é a primeira observação que deve ser feita em relação à $\mathrm{ADPF}$, por terem recebido uma medida jurídica específica, que visa à reparação do seu descumprimento.

Impende delinear o conceito de preceitos fundamentais, usado para auxiliar o entendimento da ADPF. Dirley da Cunha Júnior (2016, p. 325) orienta que o preceito fundamental deve ser entendido como toda norma constitucional tomada em sentido amplo, abrangendo, pois, norma-regra e norma-princípio -, advinda direta ou indiretamente da Constituição, que

[...] serve de fundamento básico de conformação e preservação da ordem jurídica e política do Estado. São as normas que veiculam os valores supremos de uma sociedade, sem os quais a mesma tende a desagregar-se, por lhe faltarem os pressupostos jurídicos e políticos essenciais. [...]. É o seu núcleo central, a sua alma, o seu espírito, um conjunto de elementos que lhe dão vida e identidade, sem o qual não há falar em Constituição. 
A ADPF 186, objeto deste trabalho, foi proposta, em 2009, pelo partido Democratas (DEM), o qual questionou atos administrativos do Conselho de Ensino, Pesquisa e Extensão da Universidade de Brasília (Cepe/UnB), criando a reserva de vagas oferecidas pela Universidade com base em critério étnico-racial. O proponente postulou basicamente, segundo o relatório do ministro Ricardo Lewandowski (2012), a declaração de inconstitucionalidade dos atos da Universidade de Brasília (UnB), do Conselho de Ensino, Pesquisa e Extensão da Universidade de Brasília (CEPE) e do Centro de Promoção de Eventos da Universidade de Brasília (CESPE), que instituíram o sistema de reserva de vagas com base em critério étnico-racial ( $20 \%$ de cotas étnico-raciais) no processo de seleção para ingresso de estudantes. A alegação do proponente da ADPF 186 foi que os atos da UnB ofenderiam aos arts. $1^{\circ}$, caput, III (dignidade humana); $3^{\circ}$, IV (objetivo de promover o bem de todos); $4^{\circ}$, VIII (repúdio ao racismo); 5ª I (a igualdade de homens e mulheres em direitos e obrigaçôes); $5^{\circ}$, II (o comando de ninguém é obrigado a fazer ou deixar alguma coisa senão em virtude de lei); $5^{\circ}$, XXXIII (o dever de todos os órgãos prestarem aos indivíduos informações de seu interesse particular, ou coletivo); $5^{\circ}$, XLI (o imperativo de que será punida qualquer discriminação atentatória dos direitos e liberdades fundamentais; $5^{\circ}$, LIV (o princípio do devido processo legal), 37, caput (os princípios que regem a administração pública), 205 (o direito de todos à educação), 206, caput, I (os princípios que norteiam o ensino - a igualdade de condiçóes para o acesso e a permanência na escola), 207, caput (a autonomia didático-científica das universidades), e 208, V (o acesso aos níveis mais elevados do ensino, segundo a capacidade de cada um), todos da Constituição Federal. $\mathrm{O}$ arguente sustentou, em síntese, que a discriminação existente no Brasil seria uma questão social e não racial.

Percebe-se da leitura do relatório (2012) que o proponente aduziu ainda que não se mostraria factível a adoção da teoria da justiça compensatória, seja porque não se poderia responsabilizar as geraçóes presentes por erros cometidos no passado ou porque seria impossível identificar quais seriam os legítimos beneficiários dos programas de natureza compensatória.

Ainda conforme se apreende do relatório do ministro relator (2012), o proponente também arguiu contra os atos da $\mathrm{UnB}$, que inexiste o conceito de raça, o que, segundo o arguente, teria sido olvidado nas discussóes sobre as açóes afirmativas. Asseverou, ademais, que as desigualdades entre brancos e negros não teriam origem na cor e que a "opção" pela escravidão destes teria ocorrido em razão dos lucros auferidos com o tráfico negreiro e não por qualquer outro motivo de cunho racial. Nesse momento, estamos nos atendo a relatar os argumentos dos proponentes, sem, ainda, realizarmos críticas, visto que nosso objetivo é analisar os 
votos decisórios. Embora já adiantemos que consideramos esse argumento, com o perdão da expressão, risível.

No mesmo relatório (2012), os arguidos, por meio do reitor da UNB, do diretor do CESPE e do presidente do CEPE, verificaram os argumentos de defesa do ato que realizou a reserva de vagas. A começar pela afirmação de que o combate à discriminação por meio apenas da proibição da discriminação, por si só, é medida insuficiente à implantação da igualdade, sendo fundamental combinar a proibição da discriminação com políticas que promovam a igualdade. Contra o argumento, usado para invalidar a reserva de vagas, de que, do ponto de vista científico, náo existiria raça, os arguidos alegaram que a discriminação é resultante da cor e da aparência do indivíduo e não de sua identidade genética. Afirmaram, ademais, que o sistema de reserva de cotas raciais é importante para a democratização do ensino superior, e que só deve ser abandonado quando forem eliminadas todas as restriçóes ao acesso de certas categorias sociais à universidade.

Postas essas colocaçóes, de forma a situar o tema abordado na ADPF 186, passemos à análise dos votos apresentados pelo ministro relator e da plenária do Supremo Tribunal Federal (STF) naquela ocasião. O ministro relator Ricardo Lewandowski (2012), já no início do seu voto, deixa claro que, para decidir pela constitucionalidade dos programas de ação afirmativa instituídos pela Universidade de Brasília e outros estabelecimentos de ensino superior no país, é necessário que o STF discuta o tema da forma mais ampla possível, com atenção especial aos princípios e valores sobre os quais a Carta Magna foi elaborada, principalmente o da igualdade, em sua acepção formal e material.

Lewandowski (2012) reconhece que a intenção do constituinte, ao proclamar no art. 5, caput, da Constituição Federal de 1988 que "todos são iguais perante a lei, sem distinção de qualquer natureza”, foi acolher a ideia decorrente da tradição de que o Estado não deve fazer qualquer distinção entre aqueles que estão sob o seu abrigo. Ressalta, todavia que, levando-se em conta toda a evolução política, doutrinária e jurisprudencial pela qual passou o conceito de igualdade, o constituinte buscou a máxima concreção a esse importante postulado, de forma a assegurar a igualdade material/substancial, considerando-se, pois, a diferença que distingue os indivíduos por razôes naturais, culturais, sociais, econômicas ou até mesmo acidentais, além de atentar, de modo especial, para a distinção no mundo dos fatos entre os distintos grupos sociais. É nesse contexto que floresce a necessidade de o Estado 
[...] lançar mão seja de políticas de cunho universalista, que abrangem um número indeterminado de indivíduos, mediante açốes de natureza estrutural, seja de açôes afirmativas, que atingem grupos sociais determinados, de maneira pontual, atribuindo a estes certas vantagens, por um tempo limitado, de modo a permitir-lhes a superação de desigualdades decorrentes de situaçôes históricas particulares (LEWANDOWSKI, 2012, p. 50).

A ministra Rosa Weber (2012) afirmou, em sua colocação, que a igualdade formal permite que todos sejam tratados, em abstrato, da mesma forma, sem considerar outros critérios que não seja o seu reconhecimento como sujeito de direito; é, pois, nas palavras da ministra uma igualdade presumida, posto que não leva em conta processos sociais concretos de formação de desigualdades. $\mathrm{E}$ uma vez "identificadas essas desigualdades concretas, a presunção de igualdade deixa de ser benéfica e passa a ser um fardo, enquanto impede que se percebam as necessidades concretas de grupos que, por não terem as mesmas oportunidades, ficam impossibilitados de galgar os mesmos espaços daqueles que desfrutam de condiçôes sociais mais favoráveis” (WEBER, 2012, p. 125).

Dando continuidade à sua argumentação, Lewandowski (2012) traz a abordagem da justiça distributiva, como um instrumento de transformação do direito à isonomia em igualdade de possibilidades, de forma que se assegure a igualdade no ponto de partida. $\mathrm{O}$ ministro esclarece que:

Só ela permite superar as desigualdades que ocorrem na realidade fática, mediante uma intervenção estatal determinada e consistente para corrigi-las, realocando-se os bens e oportunidades existentes na sociedade em benefício da coletividade como um todo (LEWANDOWSKI, 2012, p. 53).

Outra questáo levantada pelos arguentes da ADPF 186 e analisada pelo relator diz respeito aos critérios de ingresso no ensino superior. Nesse ponto, o ministro buscou enfrentar e pacificar a discussão em torno do conflito da chamada meritocracia e as necessidades de adoção de critérios diferenciados que asseguram determinadas vantagens a alguns indivíduos, de forma que supere as desvantagens do plano fático. Consoante às palavras do ministro relator, a Constituição de 1988, adota, simultaneamente, a igualdade de acesso, o pluralismo de ideias e a gestão democrática como princípios norteadores do ensino, e acolhe a meritocracia como parâmetro para a promoção aos seus níveis mais elevados (LEWANDOWSKI, 2012) ${ }^{6}$. Ressalta, porém, que o constituinte buscou equilibrar o rigor da aferiçáo do mérito dos candidatos que almejam o ingresso na universidade com o princípio 6 Aqui, o ministro refere-se aos art. 206, I, III e IV, 208, V, todos da Constituiçáo Federal. 
da igualdade material que permeia todo o texto magno (LEWANDOWSKI, 2012). Isso porque critérios objetivos de seleção - pretensamente isonômicos e parciais -, empregados de forma linear em sociedades tradicionalmente marcadas por desigualdades profundas, a exemplo da brasileira, acabam por consolidar ou, até mesmo, acirrar as distorçóes existentes (LEWANDOWSKI, 2012).

Lewandowski (2012) analisa, ainda, outra questão de suma importância para o tema em debate, qual seja, a referente à adoção do critério étnico-racial, para fins de qualquer seleção de pessoas, dada a comprovação científica da inexistência do conceito biológico ou genético de raça no concernente à espécie humana. A esse respeito, conclui o ministro:

Cumpre afastar, para os fins dessa discussão, o conceito biológico de raça para enfrentar a discriminação social baseada nesse critério, porquanto se trata de um conceito histórico-cultural, artificialmente construído, para justificar a discriminação ou, até mesmo, a dominação exercida por alguns indivíduos sobre certos grupos sociais, maliciosamente reputados inferiores (LEWANDOWSKI, 2012, p. 65).

Dada a importância da discussão, é preciso trazer o pensamento dos estudiosos da questáo racial sobre o conceito de raça utilizado nesse contexto. Assim, atestando a afirmação do ministro, Bernardino (2002) declara que a recusa em reconhecer raças no Brasil é uma estratégia colocada em prática, apenas, nos momentos de conceder benefícios àqueles que são identificados como membros do grupo de menor status. $\mathrm{O}$ que não indica, contudo, que a não separação de raças do ponto de vista biológico signifique "que elas náo estejam separadas, do ponto de vista social, da concessão de privilégios e distribuição de puniçóes morais, econômicas e judiciais" (BERNARDINO, 2002, p. 255).

Destacamos, também, as palavras de Lewandowski (2012, p. 66) no que concerne à consciência étnico-racial como fator de exclusão. Afirma que outro aspecto a ser considerado é o fato de que os programas de ação afirmativa adotam como ponto de partida a consciência de raça existente nas sociedades com o escopo final de eliminá-la. Isto é, o escopo desses programas é colocar um fim àquilo que foi seu termo inicial, ou seja, o sentimento subjetivo de pertencer à determinada raça ou de sofrer discriminação por integrá-la.

Para o ministro (LEWANDOWSKY, 2012), a criação de lideranças entre esses grupos discriminados, capazes de lutar pela defesa de seus direitos, além de servirem como paradigmas de integração e ascensão social, é outro resultado significante das políticas de açóes afirmativas. E isso acarreta uma mudança 
subjetiva na atitude dos integrantes dos grupos que foram historicamente relegados à margem da sociedade. A nosso ver, a partir de uma leitura foucaultiana, são nessas relaçôes e jogos de poder, nas quais indivíduos e grupos são cunhados como marginais, que surgem as possibilidades de resistência. Uma vez que, consoante Foucault, só há relação de poder, quando há para os sujeitos a possibilidade de fuga, pois o poder, em sua visão, náo é algo estático, o que o leva a caracterizar as relaçôes de poder como móveis, reversíveis e instáveis (FOUCAULT, 2006). Destarte, a introspeção, pelos indivíduos integrantes da população negra, de que é possível libertar-se da situação de submissão da qual sempre foram vítimas, é possível avançar nessa difícil tarefa e se opor a uma realidade que insiste em se pautar na desigualdade.

Destarte, as políticas de ações afirmativas, mais especificamente as cotas raciais, desempenham importante papel na construção positiva da identidade negra. Como afirma Bernardino (2002, p. 263), a adoção de políticas racializadas possibilita a atribuição de um valor positivo à classificação social do negro, nas palavras do autor "as políticas de ação afirmativa contribuem para a ampliação do número de pessoas que compartilham a identidade negra”.

Colocadas essas questóes, segue-se com a abordagem de temas que contribuirão para a conclusão acerca do perfil epistemológico da decisão da ADPF 186.

\section{Ativismo hermenêutico fenomenológico na arguição de descumprimento de Preceito Fundamento 186}

O termo ativismo judicial carrega uma indeterminação de nomenclatura, que causa confusóes, tornando-lhe alvo de críticas, além de resultar na sua utilização de forma pejorativa. Não nos deteremos, porém, às discussôes a respeito da sua terminologia, tendo em vista os objetivos traçados para este trabalho. Ao se referir ao ativismo judicial, então, deve-se ter em mente, aqui, a concepção apresentada por Barroso (2009) de uma postura, um modo proativo e expansivo de interpretar a Constituição, simbolizando uma participação mais ampla e intensa do Judiciário na concretização dos valores e fins constitucionais, com maior interferência do Judiciário no espaço de atuação dos outros dois poderes. Enseja, pois, conforme Cittadino (2004), uma expansão da ação judicial, característica marcante das sociedades democráticas contemporâneas, e, viabilizada pela incorporação de princípios aos textos constitucionais, que acaba por permitir interpretaçóes construtivas. 
De acordo com as liçôes de Barroso (2009), essa postura pode ser concretizada por diferentes condutas, que abarcam: (i) a aplicação direta da Constituição a situaçóes não expressamente contempladas em seu texto; (ii) a declaração de inconstitucionalidade de atos normativos emanados do legislador, com base em critérios menos rígidos que os de legítima violação da Constituição; (iii) a imposiçáo de condutas ou de abstençôes ao Poder Público, notadamente em matéria de políticas públicas.

O surgimento dessa nova postura construtiva do intérprete, proporcionada, como foi mencionado, pela inclusão de princípios nas Constituiçôes, justifica, segundo Lenio Streck (2002), o reconhecimento da função estratégica do Poder Judiciário, especialmente da Jurisdição Constitucional, nas Constituiçôes do pós-guerra e pode se consolidar, segundo o autor, pela vertente substancialista ou procedimentalista. Na síntese salutar de Eduardo Appio (2007), o valor mais importante para os procedimentalistas são as regras do jogo democrático, enquanto para os substancialistas, são os Direitos Fundamentais. Grosso modo, para os procedimentalistas, a melhor maneira de preservar os Direitos Fundamentais é assegurar o funcionamento dos procedimentos democráticos e dar acesso às minorias a essas estruturas, de modo que os juízes exerçam uma função de reforço e preservação das estruturas da democracia. Para substancialistas, em apertada síntese, por mais importante que seja o procedimento ele pode não ser suficiente para assegurar o mais importante e que autoriza a atuação dos juízes: a correção.

Dos autores pelos quais abordaremos o ativismo judicial um é substancialista (Dworkin) enquanto outro se aproxima do procedimentalismo (Garapon). Essa função estratégica do Poder Judiciário, quer mais ou menos substantiva ou procedimentalista será interpretativa. Daí a importância, em nossa ótica, da virada fenomenológica sobre a interpretação. Em síntese simplificadora, precária e não rigorosa, somos seres interpretativos, lançados no mundo, interpretando outros seres, limitados por nossa finitude. Passemos, portanto, à breve análise da fenomenologia hermenêutica heideggeriana.

Heidegger (2005, p. 58) enuncia que fenômeno quer dizer "o que se mostra, o que se revela". Carneiro (2011) ensina que, ao percorrer o caminho em direção ao ser, é preciso tomar o ente como um ponto de partida. E é pelo fato de se direcionar ao sentido do ser, que a fenomenologia heideggeriana é uma fenomenologia hermenêutica.

A postura construtiva do intérprete em face de princípios e direitos fundamentais, e, no caso desse artigo, especificamente, preceitos fundamentais, no exercício interpretativo, da referida função estratégica do Poder Judiciário, requer a aproximaçáo da literatura acerca do ativismo judicial com a hermenêutica 
fenomenológica. Apresentamos, entấo, como proposta epistemológica de análise o ativismo hermenêutico fenomenológico como a postura do intérprete diante do texto normativo - marcado pela temporalidade, pela tradição e por conceitos prévios -, na busca da construção de um sentido, entre várias possibilidades que se torna possível porque a verdade, segundo a concepção heideggeriana, não está na proposiçáo (texto), mas é alcançada, enquanto possibilidade, pelo processo de desvelamento histórico, que se dá entre o texto e o intérprete. Ressaltando, desde já, que essa construção não se apresenta de forma arbitrária, porquanto os juízos presentes quando nos colocamos diante do fenômeno estão constituídos e circundados na realidade histórica. Intérpretes, como sujeitos de linguagem, seres finitos e históricos náo são absolutos sujeitos independentes e senhores de suas consciências. Mas, sim, por isso, será necessária a vigilância do sujeito, para que tenha consciência das suas pré-compreensóes, para que faça na maior medida possível a entrada correta no círculo hermenêutico, como passaremos a expor. Limites metodológicos, portanto, sempre serão precários e insuficientes, a questão não é metodológica, é ontológica. Decidir é fazer um desvelamento provisório na historicidade, que por força da decidibilidade do direito, será provisoriamente definitivo, ou melhor, estável. É claro que neste desvelamento hermenêutico ontológico, compóem a tradição os conteúdos ou comandos éticos ou de correção, que contribuem para a força dessa estabilidade.

\subsection{O desvelamento na historicidade}

Realizar direitos fundamentais, incluindo minorias e preservando a democracia, é um grande desafio interpretativo. Requer a realização do que é devido, do que é bom, razoável, justo, do que é melhor. Os campos deontológico e axiológico sobrepóem-se e exigem uma análise de correçáo, dito em outros termos, da verdade. Esse sempre foi um grande desafio filosófico e hermenêutico. O questionamento acerca da verdade é tema essencial no pensamento de Heidegger, e, muito caro à virada fenomenológica sobre a interpretação, aqui abordada. A verdade, segundo a concepção heideggeriana, não está na proposição (texto), mas é alcançada, enquanto possibilidade, pelo processo de desvelamento histórico, que se dá entre o texto e o indivíduo. "A interpretação se funda existencialmente na compreensão e não vice-versa. Interpretar não é tomar conhecimento do que compreendeu, mas elaborar as possibilidades projetadas na compreensão" (HEIDEGGER, 2005, p. 204).

Segundo Heidegger (2001, p. 286) "a proposição verdadeira significa: ela descobre o ente em si mesmo. Ela propóe, indica, 'deixa ver' o ente em seu ser 
e estar descoberto. $\mathrm{O}$ ser verdadeiro (verdade) da proposição deve ser entendido no sentido de ser-descobridor". Carneiro (2001), elucidando o pensamento de Heidegger afirma que o logos, aquilo que faz ver, a proposição, não é o lugar da verdade. Portanto, a verdade não é a concordância entre o juízo e seu objeto, como nossa tradição aristotélica insiste, mas, remete à ontologia fundamental. Razão pela qual o ente se mostra, mas não em sua totalidade. Não por um defeito da verdade, e sim por uma imposição das nossas limitações compreensivas, de forma que a tentativa de compreender a totalidade do ente que se mostra será sempre frustrada pela nossa finitude. Heidegger (2005, p. 161) afirma que "'deixar-ser' significa o entregar-se ao ente [...] entregar-se ao aberto e à sua abertura, no qual todo ente entra e permanece, e que cada ente traz, por assim dizer, consigo".

Aqui surge, porém, outra questão (que já antecipamos no tópico anterior), qual seja, a de saber se o que se mostra não é uma característica objetiva do ente, o acontecer da verdade, ou a construção/antecipação do sentido do ente (texto normativo), seria uma subjetividade arbitrária. Carneiro (2011, p. 123) explica que, conquanto o que se mostra não seja o ente objetivamente, "também não é um sentido subjetivo que implique a arbitrariedade do intérprete e que coloque a compreensão à 'disposição' do sujeito". O autor declara que há algo de subjetivo na compreensão, uma vez que o que acontece depende da história do sujeito - da temporalidade, como afirmamos -, o que não significa que esse acontecer seja arbitrário, porque ele não terá tempo para optar por um projeto compreensivo determinado.

A essa altura podemos afirmar, então, que a verdade se dá enquanto desvelamento, isto é, enquanto um movimento que se dá entre o texto e o sujeito, que carrega consigo a sua história, sua tradição, seus conceitos prévios, o seu projeto compreensivo, que vai ser o ponto de partida para a antecipação de sentido daquilo se mostra (nesse caso, o texto), e, posteriormente à interpretaçáo, conforme novos elementos se apresentem e forcem a revisão constante dos projetos compreensivos.

O projeto compreensivo constitui elemento central para o pensamento de Heidegger sobre o que ele denomina círculo hermenêutico e que vai influenciar o pensamento de Gadamer. Para Heidegger (2005, p. 198), a compreensão é existencial, pois ela "não é uma coisa, mas o ser como existir". Por isso, Carneiro afirma (2011, p. 69), "sempre compreendemos; estamos condenados à compreensão". Nós somos o ente privilegiado capaz de compreender o ser dos demais entes (CARNEIRO, 2011). E compreendemos enquanto ser-no-mundo, isto é, nós compreendemos o ente que se mostra enquanto seres históricos e finitos que somos. É nessa condiçấo histórica que nos colocamos diante do ente (e do texto) já possuindo a compreensão dele, de tal forma que só compreendemos 
porque já temos a compreensão. É nessa circularidade que Heidegger fará a distinção entre compreensão e interpretação, ao afirmar que:

[...] O projetar da compreensão possui a possibilidade própria de se elaborar em formas. Chamamos de interpretaçấo essa elaboração. Nela, a compreensão se apropria do que compreende. $\mathrm{Na}$ interpretação a compreensão se torna ela mesma e não outra coisa. A interpretação se funda existencialmente na compreensão e nấo vice-versa. Interpretar não é tomar conhecimento do que compreendeu, mas elaborar as possibilidades projetadas na compreensão (HEIDEGGER, 2005, p. 204).

Gadamer (2015, p. 354) afirma a necessidade de "corrigir a autocompreensão que se exerce constantemente na compreensão, livrando-a de adaptaçóes inadequadas", a necessidade de "corrigir a autocompreensão que se exerce constantemente na compreensão, livrando-a de adaptaçóes inadequadas". Para o autor, quem pretender compreender um texto, realiza sempre um projetar, e, a compreensão do que está posto no texto consiste na elaboração desse projeto prévio, que precisa ser constantemente revisado com base no que se dá conforme se avança na penetração do sentido. A busca pela compreensão está sujeita a erros por conta de opinióes prévias que não se confirmam nas próprias coisas, sendo necessário elaborar projetos corretos (a entrada correta no círculo hermenêutico) e adequados às coisas (GADAMER, 2015). Segundo Gadamer (2015, p. 355), “é preciso que o intérprete volte o seu olhar para as 'as coisas mesmas' ${ }^{7}$, o que concebe verdadeiramente 'a tarefa primeira, constante e última do intérprete'”, destacando, pois, que toda interpretação correta terá que se proteger da arbitrariedade de intuiçôes repentinas.

\subsection{A presença de Heidegger e Gadamer na ADPF 186}

Após a exposição teórica que ampara este trabalho, chega-se à tarefa primordial proposta, qual seja, a análise dos votos da plenária do Supremo Tribunal Federal, no julgamento da Arguição de Descumprimento de Preceito Fundamental 186, com o escopo de evidenciar a tese do seu perfil ativista de teor hermenêutico de fundo fenomenológico, ainda que não se encontre uma reflexão expressa acerca dos autores aqui trabalhados. Neste tópico, debruçar-nos-emos sobre o inteiro teor do acórdáo daquele julgamento, na busca da presença de Heidegger e Gadamer.

Ao iniciarmos a leitura do voto do ministro Ricardo Lewandowsky, relator da ADPF 186, é possível, desde logo, perceber em suas palavras a ideia levantada

7 Que, segundo ele, para filólogos, são textos com sentido, que tratam, por seu turno, de coisas. 
por Heidegger de que a verdade não se encontra, necessariamente, na proposição (isto é, no texto), vez que ela pode enunciar ou não a verdade. Apontamos essa conclusão no sentido de expressar o esforço do ministro para defender que os textos normativos não apresentam sentidos engessados, ou unívocos. Isso é feito no momento em que o julgador enfrenta a tese dos arguintes da ADPF 186 de que as políticas de reserva de vagas, baseadas no critério étnico-racial seriam inconstitucionais, porquanto violam o disposto no art. $5^{\circ}$, caput, da Constituição Federal, de que todos são iguais perante a lei, sem distinção de qualquer natureza.

Como apontamos anteriormente, a verdade ocorre enquanto desvelamento, isto é, enquanto movimento entre o texto e o sujeito, que se lança na tarefa de interpretá-lo. Essa interpretaçáo, porém, não se dá de forma imediata e de uma vez por todas; pelo contrário nós interpretamos, segundo a concepção heideggerianagadameriana, porque ao nos colocarmos diante do texto já temos, em relação a ele, a nossa compreensão, isto é, lançamos sobre o nosso projeto compreensivo que busca antecipar as possibilidades de sentidos do texto. A interpretação se dá, entâo, na medida em que novos elementos se apresentam, e nós precisamos refazer o nosso projeto compreensivo.

Isso fica claro, por exemplo, no instante em que o relator busca revisitar o princípio da igualdade inserido na Constituição - à luz dos princípios e valores sobre os quais ela repousa -, como primeiro passo para que se efetive uma ampla discussão acerca da constitucionalidade das açôes afirmativas. Ele declara que é preciso discuti-lo em seu duplo aspecto, formal e material (LEWANDOWSKY, 2012). Defende que o legislador constituinte de 1998

[...] não se restringiu apenas a proclamar solenemente, em palavras grandiloquentes, a igualdade de todos diante da lei. À toda evidência, não se ateve ele, simplesmente, a proclamar o princípio da isonomia no plano formal, mas buscou emprestar a máxima concreção a esse importante postulado, de maneira a assegurar a igualdade material ou substancial a todos os brasileiros e estrangeiros que vivem no País, levando em consideração - é claro - a diferença que os distingue por razóes naturais, culturais, sociais, econômicas ou até mesmo acidentais, além de atentar, de modo especial, para a desequiparaçáo ocorrente no mundo dos fatos entre os distintos grupos sociais (LEWANDOWSKY, 2012, p. 49-50). 
Afirmamos identificar, aqui, a presença de Heidegger na medida em que o ministro busca o sentido do preceito de igualdade insculpido na Carta Magna não de forma superficial e linear, por meio, apenas, das palavras positivadas no texto, e sim buscando elementos que o auxiliem na tarefa de alcançar o sentido mais completo possível. Dessa forma, conforme se aprofunda nas possibilidades de sentidos que se apresentam, e, que forçam a reformulaçáo do seu projeto compreensivo, a verdade (ou o significado correto possível) desvela-se nessa circularidade entre o texto e o intérprete. Essa postura, aliás, foi seguida por todos os ministros que o seguiram, que procuraram interpretar corretamente o problema que se apresentava naquela ocasião, buscando, para isso, olhar a problemática (fenômeno) para além do texto normativo, trilhando um caminho de diferentes possibilidades de significaçôes. E depreendemos a mesma conclusão da leitura do voto do ministro Luiz Fux (2012), quando ele afirma que, para se chegar a uma solução justa, buscou unir a técnica a fatores externos, como a história brasileira marcada pela escravatura.

Essa busca pela interpretação correta - compreendida a correçáo como possibilidade - foi estruturada, para além de uma entrada correta no círculo hermenêutico, por uma compreensão do problema no próprio contexto histórico, na história da sociedade brasileira, com a consciência, pois, da ideia defendida por Gadamer de que é preciso, antes de refletirmos sobre o texto que se mostra, compreender a nossa história, já que pertencemos a ela, e, toda significação é construída no seu desenrolar, na conjuntura. Constata-se essa concepção gadameriana nas palavras da ministra Cármen Lúcia, em sua antecipação de voto, em que ela afirma que fará as suas observaçôes, para pontuar a questão como ela a entende (ROCHA, 2012) - e é como ela a entende em sua história. A ministra, após expor os pontos sobre os quais o seu voto repousara - no que é a igualdade e igualação, a questão da liberdade de ser, e sobre a responsabilidade social e estatal de fazer que o princípio da igualdade se cumpra - relata duas experiências de vida, que a inspiraram a escrever e pensar sobre o princípio da igualdade, e, claro, contribuíram para a sua interpretação da questão em julgamento (ROCHA, 2012).

O primeiro relato da ministra diz respeito a uma ocasião na qual ela presenteou duas sobrinhas com duas bonecas negras, causando de imediato uma reação negativa de uma das meninas. Ao questionar a criança sobre o motivo que levara àquele comportamento, obteve a seguinte resposta: "[...] é feia, parece comigo" (ROCHA, 2012, p. 133). Esse fato levou Cármen Lúcia à seguinte conclusão: 
A família descobriu que, em algum lugar sem amor, a menina construía dentro de si uma imagem negativa de si a partir de algo que nem sabíamos. A marca de uma pessoa que tem um espelho que é o outro, tấo diferente, é uma marca que assinala a fragilidade humana, difícil de se recompor quando atingida. Ninguém nunca disse nada sobre a cor em minha casa, até onde me consta. Aquela menina é que, nas escolas onde frequentava, não se reconhecia como padrão, como modelo que não era aquele dela. Por isso ela não aceitava o meu presente (ROCHA, 2012, p. 133).

O segundo caso relatado pela ministra descreve uma situação vivida por ela na PUC de Minas. Cármen Lúcia conta que ao entrar em uma lanchonete, uma menina, chamada Lucia, pediu-lhe que comprasse um salgado, entregando-lhe o dinheiro. Sem entender, a ministra, pediu que explicasse o motivo de ela mesma não comprar, já que o dinheiro era seu. A criança, então, lhe responde: "Eu não posso entrar aí, porque sou negra, e, se eu entrar, vão achar que o dinheiro não é meu" (ROCHA, 2012, p. 133). E, a respeito desse fato, afirma a ministra:

E ela estava numa condição absolutamente igual a qualquer pessoa que, com dinheiro, queria e poderia comprar o que quisesse. $\mathrm{O}$ que significa que, quando a gente marca, na infância, com um sinal de inferioridade, pela desigualdade de oportunidades comuns, não pode ser desconhecido pela sociedade como se nada tivesse acontecido, como se nós tivéssemos uma democracia racial, como se não tivéssemos nenhuma dificuldade. E desconhecer isso náo muda, de jeito nenhum, a sociedade (ROCHA, 2012, p. 133-34).

Concluímos, então, por uma presença da hermenêutica de Gadamer, na medida em que a ministra procura enfrentar a questão das açôes afirmativas, mais especificamente das cotas raciais, tomando como ponto de partida, como referência, a sua condição histórica, a sua condição de ser-no-mundo, e, que, por isso, não pode (ou não consegue) se esquivar de uma análise que perpasse as diferentes possibilidades de interpretação. Em outras palavras, a ministra, ao analisar a questão da constitucionalidade das cotas raciais, tinha a consciência de que era preciso ir além de uma leitura linear e superficial da Constituição a respeito da igualdade. Ela, assim como os outros julgadores daquela plenária, analisaram a problemática tomando como ponto de partida as suas concepçôes prévias, seu conhecimento acerca da sociedade na qual estamos inseridos, que como afirmamos, foi "construída" à custa do sofrimento da população negra. E, por essa razão, não é justo tomar o texto normativo como parâmetro absoluto, 
como algo que resolve, ou apaga, as desigualdades que, ainda, se perpetuam na comunidade política.

Nesse mesmo sentido, aliás, aponta o ministro Gilmar Mendes (2012) ao destacar em seu voto que a solução para a inclusão social daqueles que não têm acesso a bens fundamentais, como a educação e o emprego, requer uma interpretação do texto constitucional que considere as especificidades históricas e culturais da sociedade brasileira. Assim como o ministro Luiz Fux (2012, p. 105), quando defende que umas das premissas indispensáveis para o correto enquadramento jurídico-constitucional das políticas de ações afirmativas é de que "a abolição do regime escravocrata ocorrida no final do século XIX, embora tenha suprimido formalmente a submissão do negro, não apagou o código racial que até hoje viceja dissimuladamente nas relaçôes sociais do país". É imprescindível, portanto, a consciência de que a (des)construção de uma realidade normativa, não significa, necessariamente, a (des)construçáo de uma realidade fática e social.

\subsection{A presença de Antoine Garapon na ADPF 186}

O crescente protagonismo do Poder Judiciário face à derrocada da instituição política é a consequência de uma democracia desorientada, afirma Antonie Garapon (2001). Segundo o jurista francês, os juízes, nas últimas décadas, são chamados a se manifestarem em um número da vida social cada vez mais extenso, de forma que o contencioso e as jurisdiçóes passaram a afirmar, cada vez mais, a sua autoridade (GARAPON, 2001). E, esse fenômeno é detectado primeiro na vida política, com o desenvolvimento do que os norte-americanos denominaram de "ativismo judicial", quando o juiz passa a ser eleito como árbitro de costumes, bem como da moralidade política, além de tornar-se uma referência do indivíduo moderno, que já se encontra sem raízes, na busca de uma identidade (GARAPON, 2001). Em suas palavras:

O juiz surge como um recurso contra a implosão das sociedades democráticas que não conseguem administrar de outra forma a complexidade e a diversificação que elas mesmas geraram. O sujeito, privado das referências que dáo identidade [...] procura no contato com a justiça uma muralha contra o desabamento interior (GARAPON, 2001, p. 27).

É preciso, todavia, ter-se em mente que o desenvolvimento do ativismo judicial é apenas um sintoma de um processo complexo, pois não se pode concebê-lo como uma transferência de soberania para o juiz, e sim como uma 
transformação da própria democracia, uma vez que o direito tenha se transformado no instrumento das demandas políticas, por causa da desilusão em um Estado inativo (GARAPON, 2001). Por isso, Garapon (2001) salienta, para evitar conclusôes distorcidas, que o ativismo judicial "não se trata da ação esporádica de alguns juízes desmiolados que querem brigar com o poder político”, mas é resultado do lugar simbólico conquistado pelo julgador (terceiro imparcial). E a sociedade busca cada vez mais essa referência simbólica em razão do descrédito que degenera as instituiçóes políticas clássicas . Assim, defende o autor (GARAPON, 2001, p. 49), "justiça torna-se um espaço de exigibilidade da democracia", pois os processos judiciais "circunscrevem novos compromissos, colocam problemas sociais, tornam visíveis categorias da população, abraçam esperanças [...]” (p. 48).

Embora a Arguição de Descumprimento de Preceito Fundamental 186 não tenha sido proposta por setores representantes da população negra, com o escopo de ter reconhecido o seu direito de acesso à educação, não se pode negar a importância da referida ação, porquanto tenha proporcionado visibilidade à questão, e, sobretudo possibilitado o exercício da cidadania, ou seja, a exigibilidade da democracia destacada por Garapon. Possibilitou, ainda, que o Poder Judiciário estabelecesse um instrumento de efetivação da garantia constitucional da igualdade à população negra, tendo em vista a inércia política nesse sentido, como bem destacou o ministro Ayres Brito (2012, p. 212), quando registra que a Constituição não se mostra efetivamente cidadã "não por deficiência do respectivo conteúdo, mas pela ausência de vontade política de implementá-la”. Na mesma direção, pontuou o ministro Luiz Fux (2012, p. 96) que "a instância reflexiva do Poder Judiciário só se instaura quando há uma inação do parlamento. A supremacia, a instância hegemônica, que eventualmente se possa categorizar o Poder Judiciário, ocorre somente nas lacunas e no vácuo da atividade legiferante".

Essa emancipação do juiz resulta, destaca o autor, da conjugaçáo de dois fatores: o colapso da lei que garantia a subordinaçáo do juiz, e a nova possibilidade de julgar a lei oferecida pelos textos que contêm princípios superiores, como a Constituiçáo (GARAPON, 2001). A lei deixa de apresentar todos os elementos essenciais para a decisão do juiz, que deve buscar fontes externas antes de proferir suas sentenças; ela (a lei), ainda que mantenha certa importância, já não pode mais figurar como o único fundamento possível de todo o sistema jurídico (GARAPON, 2001). Esse mesmo autor escreve que não se concebe a vontade geral (expressada na lei) como a única fonte de produção de direito, de modo que ela deve tornar-se compatível com os princípios contidos nos textos básicos, como a Constituição. 
Garapon (2001), porém, não se exime de apontar os perigos que podem advir do ativismo judiciário. Segundo ele, o juiz representa a caricatura do novo anjo da democracia e passa a ser titular de um status privilegiado - do qual ele próprio expulsou o político -, eleva-se à posição de domínio, blindado à crítica popular; por isso, alerta, a justiça pode justificar o processo de despolitização da democracia (GARAPON, 2001). Por tal motivo, ele questiona se o ativismo judiciário seria possível sem a mídia, que desarticula a base da instituição judiciária, desorganizando o rito processual, na tentativa expor uma representação fiel da realidade (GARAPON, 2001).

A ministra Rosa Weber mostrou-se sensível às percepçóes de Garapon ainda que náo se encontre referência expressa - no que concerne à influência da Constituição na emancipação do juiz, por conta dos princípios contidos em seu texto e de que o judiciário tem proporcionado o exercício da democracia. Destarte, a ministra Rosa Weber (2012, p. 123) afirma que:

[...] o Supremo Tribunal Federal tem contribuído, e muito, a meu juízo, para o aperfeiçoamento da percepção da pluralidade, em nosso país, e a criaçấo de espaços democráticos de debate, em que diferentes perspectivas se sustentam, a evidenciar a abertura não apenas dos textos normativos - e somos todos nós, cidadãos brasileiros, intérpretes da Constituição -, mas também do sistema como um todo [...].

Importante consideração é feita por Garapon (2001, p. 162) ao afirmar que “o julgamento judiciário é sempre em situação e, podemos acrescentar, de uma situação. $\mathrm{O}$ que lhe dá força e, ao mesmo tempo, fragilidade. É um julgamento sob o horizonte da finitude". Compreendemos que a força é perceptível ao considerarmos que o juiz não fará um julgamento sem ponderar o fato que se coloca diante dele (o fenômeno de Heidegger), e, pois, não tomará a lei como o único filtro de julgamento, sem antes compreender a própria situação, sua história, sem antes compreender-se na sociedade (como alertou Gadamer). E sem apreciar o seu conteúdo, como ele próprio afirma (GARAPON, 2001). Sua fragilidade, por outro lado, é apresentada pelo próprio Garapon (2001) quando escreve que o contato que se opera entre o juiz e a realidade é sempre intermediado pelo direito, pelo processo, não sendo possível um julgamento "puro", alheio às condiçôes físicas de sua realização.

O juiz, aliás, exerce o papel, segundo Garapon (2001, p. 186), de "preservação da memória para preencher o vazio existencial e permanente da tradição”, gerado pelo esquecimento do passado, típico das sociedades democráticas. Por isso, o autor 
ressalta que "O juiz é o guardiāo da memória, mas de uma memória reforçada: aquela das promessas que os fundadores fizeram em nossa intenção" (GARAPON, 2001). Ademais, é possível afirmar que a ideia expressa por Garapon corrobora a concepção heideggeriana, já apresentada anteriormente, da nossa condição de seres existenciais e finitos, e que, por isso, não compreende senão existencialmente.

A concepção de que o julgamento é sempre de uma situação, e, pois de que o juiz deve, ao julgar, levar em consideração o fato que está sob julgamento foi percebida pelo ministro Cezar Peluso ao analisar a compatibilidade das açôes afirmativas com o princípio constitucional da igualdade, ou com outro princípio constitucional, e, estabelecer como premissa o

[...] fato sócio-histórico incontroverso, ao qual chamou 'déficit educacional e cultural da etnia negra', observado desde os primórdios do processo histórico da vida brasileira, em virtude das graves e conhecidas barreiras institucionais de acesso dos negros às fontes da educação e da cultura (PELUSO, 2012, p. 155).

Reconheceu, por conseguinte, conforme a nossa compreensão, que não é possível um julgamento calcado apenas no texto normativo, sem que se considerasse a situação sob julgamento naquela plenária, qual seja, a desvantagem da população negra no plano fático.

Por fim, trazemos o modo como Garapon aborda esse papel ativo do juiz, que, adiantamos, encerra uma visão procedimentalista. Segundo o autor, os novos espaços da justiça representam uma forma de democracia descentralizada, tendo em vista que o Estado passa a exercer o seu papel normativo pela negociação coletiva, isto é, homologando o direito estabelecido pelas próprias partes, o que garante uma correlação entre o direito e a realidade social (GARAPON, 2001). O processo apresenta-se como um meio de apreender a realidade, posto que a norma não goza mais de "conteúdo geral e universal deduzido a priori, cabendo ao juiz atualizar e contextualizar seu espírito, incessantemente" (GARAPON, 2001, p. 238). Ou seja, o conteúdo da norma é alcançado pelo processo de conjugação entre texto abstrato e realidade concreta - é o processo gadameriano de compreensão da realidade e interpretação do texto.

\subsection{A presença de Ronald Dworkin na ADPF 186}

A obra de Ronald Dworkin representa incontestável contribuição à doutrina jurídica, mormente à discussão acerca da teoria do Direito. Não temos, porém, a intenção de elaborar um ensaio sobre as teses defendidas pelo autor, tendo em 
vista os limites traçados para este trabalho, qual seja, a análise da Arguição de Descumprimento de Preceito Fundamental 186, com vistas à identificação, ainda que não explicitamente, da influência do ativismo judicial de Dworkin.

Segundo o autor, em alguns momentos os juristas lidam com problemas que não são técnicos, sobre os quais não há consenso sobre o modo de proceder (DWORKIN, 2005). São os casos difíceis, na denominação dada pelo autor. Difíceis porque sobre eles não há consenso, ultrapassam a técnica, trazem desafios e discussóes sobre os limites da atuação da função judicante. Nessa linha conceitual, certamente se pode dizer que a ADPF 186 foi um caso difícil.

Para Dworkin (2005), ao levantar questionamentos sobre a postura dos juízes diante de casos difíceis, como se eles estivessem seguindo regras gerais e abstratas (e de onde elas provêm e o que as tornam válidas), ou se os juízes estão decidindo o caso de acordo com suas próprias crenças morais e políticas; o que se questiona, de fato, não é o sentimento de que os juízes que criam regras novas estão agindo de maneira imprópria, e sim sobre até que ponto a justificativa para o poder dos juízes, disponível para os casos fáceis - aquela segundo a qual o juiz está aplicando normas já estabelecidas -, estende-se também aos casos difíceis. Querem saber, portanto, quanto e que tipo de justificação suplementar é exigida por esses casos difíceis. A questáo, no fundo, é pela justificativa para o uso do poder.

Para Dworkin, quando da interpretação e aplicação dos dispositivos normativos, o positivismo náo se sai bem quanto a essa questão da justificativa para o uso do poder. No fim, restará apenas a discricionariedade para o uso do poder, sem a justificativa. "O positivismo é um modelo de e para um sistema de regras e que sua noção central de um único teste fundamental para os direitos nos força a ignorar os papéis importantes desempenhados pelos padrôes que não são regras" (DWORKIN, 2005, p. 36).

No entanto, adverte o autor estadunidense, mesmo quando nenhuma regra regula o caso, uma das partes pode, ainda assim, ter o direito de ganhar a causa, isto é, "o juiz continua tendo o dever, mesmo nos casos difíceis, de descobrir quais são os direitos das partes”. Para Dworkin, ao fazer isso, o juiz não está a “inventar novos direitos retroativamente" (DWORKIN, 2005, p. 127). Está, hermeneuticamente, a realizar os direitos veiculados fora dos padrôes das regras, as "questóes de princípio" ${ }^{8}$. E ressalva que não há procedimento mecânico para essa realizaçáo.

$8 \mathrm{Na}$ obra de Dworkin, a diferença entre regras e princípios é de natureza lógica, isso porque as regras se aplicam à maneira do tudo ou nada - ou são válidas, e, por isso, seu conteúdo deve ser aceito, ou não são, e neste caso não contribuem para uma decisão -, ao passo que um princípio "ao contrário, enuncia uma razão que conduz o argumento em uma certa direção, mas [ainda assim] necessita uma decisão particular” (DWORKIN, 2005, p. 41). Os princípios apresentam uma dimensão de peso ou importância, que as regras não têm. 
Ainda que sem menção expressa a Dworkin, percebe-se essa perspectiva de inovar dentro da tradição, realizar um novo direito, porém na perspectiva de um direito princípio já existente no julgamento da ADPF 186. Embora a decisão em prol da ação afirmativa tenha sido inédita, foi fundamentada no já existente direito à igualdade, ao qual foi conferido "novo" significado. Conforme se verifica do excerto do voto do ministro Ricardo Lewandowscky, já transcrito alhures:

[...] (o legislador constituinte) não se restringiu apenas a proclamar solenemente, em palavras grandiloquentes, a igualdade de todos diante da lei. A toda evidência, não se ateve ele, simplesmente, a proclamar o princípio da isonomia no plano formal, mas buscou emprestar a máxima concreção a esse importante postulado, [...] levando em consideraçáo - é claro - a diferença que os distingue por razóes naturais, culturais, sociais, econômicas ou até mesmo acidentais, além de atentar, de modo especial, para a desequiparação ocorrente no mundo dos fatos entre os distintos grupos sociais (LEWANDOWSKY, 2012, p. 49-50).

Para aqueles que consideram que o Judiciário estaria agindo como legislativo ao julgar os casos difíceis, Dworkin (2005) alerta ser errôneo pressupor que os juízes estão legislando quando vão além de decisões políticas tomadas anteriormente. Pressupor o contrário seria olvidar a importância de uma distinção feita pelo próprio Dworkin entre argumentos de princípio e argumentos de política9 (DWORKIN, 2005, p. 129). Nesse caso, pois, seriam (e foram) os argumentos de princípios utilizados no julgamento da ADPF 186, para justificar a necessidade das açóes afirmativas, visando a garantia da inclusão a uma minoria em estado de desigualdade social. Dworkin (2007, p. 129-30), aliás, conquanto não se referindo, especificamente, às cotas, mas à discriminaçáo racial, afirmou que "o argumento em favor das leis contra a discriminação, aquele segundo o qual uma minoria tem direito à igualdade de consideração e respeito, é um argumento de princípio".

Como já assentado há pouco, os ministros do Supremo Tribunal Federal, quando da argumentação favorável à constitucionalidade das açóes afirmativas que visam à garantia do acesso/inclusão da população negra ao espaço que sempre lhe foi negado, sustentaram que as referidas açôes estavam em concordância com o princípio constitucional da igualdade, em seu aspecto material - que assegura o tratamento desigual àqueles que, na realidade, se encontram em situação desfavorável. Nesse sentido, posicionou-se o ministro Cezar Peluso (2012, p. 156):

9 Os argumentos de política, explica Dworkin (2005), justificam uma decisão política, que apoia ou protege algum objetivo comum da comunidade, enquanto os argumentos de princípios justificam, também, uma decisão política, mas mostrando que a decisão respeita ou garante um direito ou de um grupo. 
[...] a responsabilidade ética e jurídica do Estado e da sociedade é adotar políticas públicas [...] na tentativa de desenvolver um processo - que, por definição, não se realiza num dado momento, mas que se faz e aperfeiçoa ao longo do tempo - capaz de viabilizar a desejada igualdade material e, portanto, de desfazer a injustiça histórica de que os negros são vítimas no Brasil.

Dworkin (2005) ressalta que os juristas acusam os juízes que julgam de maneira original de criar novas leis de maneira pessoal. Para ele, a questáo problema é explicar como essas diferentes contribuiçóes à decisão de um caso difícil podem ser identificadas e conciliadas. A explicação mais satisfatória acerca dessa constante interação entre a moralidade pessoal e moralidade institucional é dada pela tese segundo a qual as decisóes judiciais tornam efetivos os direitos políticos existentes. E, tomando essa tese como válida, afirma Dworkin (2005), a história institucional (isto é, os precedentes) não como uma restrição do juízo político dos juízes, e sim como um componente de tal juízo. Os direitos políticos ${ }^{10}$, proclama o autor, "são criaçóes tanto da história, quanto da moralidade" (DWORKIN, 2005, p. 136), por isso se dilui a alegada tensão entre originalidade judicial e história institucional, porquanto os juízes devam fazer novos julgamentos sobre o direito das partes, mas esses direitos políticos, antes de opor, refletem as decisóes políticas tomadas no passado. Mesmo porque os juízes devem tomar decisóes que também justifiquem decisões futuras, por conta da sua responsabilidade política (DWORKIN, 2005).

A ideia de Dworkin, de que as decisóes que "criam" novos direitos estâo perpassadas pela moralidade pessoal e institucional, pode ser detectada ao longo de todo o julgamento, porquanto os julgadores tenham válido, ao compreenderem e interpretarem o texto normativo, de suas histórias, tradiçôes - isto é, concepçóes originais e pessoais -, pautaram-se, também, pela moralidade institucional, na medida em que buscaram argumentos apresentados em decisóes anteriores do próprio STF. É o que se verifica, por exemplo, no voto da ministra Carmen Lúcia (2012), quando esta, para justificar a necessidade de superar fatores de desigualdade concreta/social, traz argumentos explicitados no julgamento do Recurso Ordinário em Mandado de Segurança n. 26.071/DF, Relator ministro Ayres Britto, em que a Primeira Turma do Supremo Tribunal Federal decidiu que a compensação e superação dos fatores de desigualdade factual é uma tarefa calcada no objetivo de uma sociedade fraterna inscrita no preâmbulo da Constituição Federal.

Para Dworkin, então, os juízes, quando julgam casos difíceis, não devem ser considerados legisladores, no sentido de criar novas leis, sem observar aquelas que

10 Quando se refere a direitos políticos, Dworkin está se referindo às questốes de princípios (que possuem dimensão moral), por considerar o Direito como integridade, e, por isso, os indivíduos e grupos têm o direito de sempre obterem uma decisão judicial, pois os seus direitos são questóes de princípios. 
já foram determinadas anteriormente. Isto é, o julgamento não está à disposição do juiz, de forma que ele possa proferir suas sentenças de acordo, apenas, com seus padróes morais. Por isso, ele afirma que "os juízes náo decidem os casos difíceis em duas etapas, avaliando, em um primeiro momento, os limites das restriçóes institucionais, para só então deixar os livros de lado e resolver as coisas a seu próprio modo. As restrições institucionais que eles intuem estão disseminadas, e perduram até a própria decisão" (DWORKIN, 2005, p. 136).

Podemos perceber as ideias de Dworkin no julgamento da ADPF 186, na medida em os ministros, ao fazerem suas colocaçóes concernentes às açóes afirmativas, apesar de levarem em consideração as particularidades da situação sob julgamento (a desigualdade da população negra), bem como suas próprias histórias, fundamentaram suas posições na Constituição de 1988, em seu conjunto - atentos, portanto, às decisóes tomadas pelo constituinte, além de basearem em julgamentos daquela corte sobre temas sensíveis a questôes semelhantes. Essa limitação é percebida, por exemplo, no voto do ministro Cezar Peluso (2012, p. 156), que expôs o seguinte:

Ora, basta uma visão sistemática da Constituição Federal para perceber, logo, que, em nome da igualdade, ela tutela classes ou grupos em situaçáo de vulnerabilidade socioeconômica. Náo preciso nem citar os casos das mulheres, dos menores, dos hipossuficientes. Há, portanto, na Constituição mesma, tratamentos excepcionais, concordes com o princípio da igualdade em relação a tais pessoas $[\ldots]$

Vejamos o trecho do voto do argumento do ministro Gilmar Mendes (2012, p. 180):

Se, por um lado, a clássica concepção liberal de igualdade como um valor meramente formal há muito foi superada, em vista do seu potencial de ser um meio de legitimação da manutenção de iniquidades, por outro o objetivo de se garantir uma efetiva igualdade material deve sempre levar em consideração a necessidade de se respeitar os demais valores constitucionais.

O primeiro trecho colacionado refere-se ao princípio da igualdade, o segundo aos valores constitucionais, aí incluído, dada a redação, o valor da igualdade em seu aspecto material. Referências expressas a princípio e valor constitucional da igualdade. Embora não haja menção expressa a Dworkin, esse é o princípio basilar de sua teoria do Direito como integridade. Tal como a decisão contra a segregação racial no caso Brown vs Board of Education, a decisão a favor das cotas 
é a única decisáo possivel ${ }^{11}$ que considera o direito em sua integridade, a realizar um direito que deve ser levado a sério, que considera uma questão de princípio: a dimensão irredutível do ser humano de ser tratado como tal. A decisão que atenta ao cumprimento da igualdade.

\section{Consideraçóes finais}

Compreender a condição histórica do ser humano, sua limitação interpretativa, é de relevância singular, posto que possibilita a compreensão do seu comportamento frente ao fenômeno que se mostra, por exemplo, a sua postura no ato de interpretação/decisão. A questão acerca da postura do juiz no que concerne à tensão entre originalidade e limites do ato decisório é questão antiga da Filosofia do Direito, que ganha relevância com a ampliação da Jurisdição Constitucional e é primordial no caso da ADPF 186.

Este trabalho lança-se sobre teorias que, em nosso entendimento, obtêm algum acerto na compreensão da questão desafiadora da definição de sentido e dos tensos possíveis limites do ato decisório: a hermenêutica heidegger-gadameriana, o pensamento de Ronald Dworkin e de Antoine Garapon.

Assim, visitou as premissas hermenêutico heidegger-gadamerianas, pelas quais o intérprete cria o significado do texto normativo a partir de um leque plural que lhe é possibilitado pela tradição na qual está imerso. De modo que compreender, interpretar e aplicar o Direito são uma só operação ontológica e, portanto, náo são métodos pueris que impedirão a dita arbitrariedade do julgador - além da própria noção do que é arbitrariedade passar por uma mudança, a partir do momento que o texto é possibilidade e o intérprete é compreendido como sujeito histórico. Entretanto, que a comunidade político-normativa fez escolhas sobre significados comunitariamente construídos aos quais julgou que devem funcionar como balizas, mas que estáo a todo tempo sob ameaça de violaçóes, quando não de ressignificação pela própria comunidade.

No julgamento da ADPF 186, percebe-se a manifestação da hermenêutica heidegger/gademeriana, na medida em que aquele se desenvolveu com o desvelamento de uma possibilidade de verdade para o texto normativo, que se mostrou ao intérprete no círculo hermenêutico ontológico, ao criar um novo projeto compreensivo para o princípio da igualdade no que diz respeito ao acesso às vagas do ensino superior no Brasil. Assim, o STF concretizou o sentido de igualdade a partir da compreensão da realidade sócio-histórica-cultural dos intérpretes que vivem sob a égide da Constituição.

$11 \mathrm{E}$ que resulta da correta entrada no círculo hermenêutico, em termos gadamerianos. 
A análise buscou em Ronald Dworkin (1999; 2007; 2014) substrato para tratar da obrigaçáo e legitimidade do juiz para julgar as questôes de princípios, aquelas questóes máximas da comunidade político-normativa, decorrentes da própria noção do princípio da igualdade, sobre o qual se assentam as comunidades políticas democráticas, mesmo quando contrariamente ao Poder Legislativo e encontrou, na decisão analisada, ressonância dessas ideias.

A pesquisa identificou, pela análise dos votos, a presença do ativismo judicial de Ronald Dworkin na atuação dos ministros do STF no julgamento da ADPF 186. Os juízes constitucionais reverberaram Dworkin, ao declarar a constitucionalidade das cotas por critérios raciais, concretizando os direitos dos indivíduos e grupos que não foram efetivados no campo político, por considerarem que se tratava de questôes de princípios.

O trabalho expóe, e concorda com o pensamento de Antoine Garapon (2001), para quem a maior margem de conformação do Poder Judiciário na definição de sentidos normativos que dizem respeito a questôes centrais da comunidade política se deve ao desmoronamento do poder político, tal como se deu, em nossa análise, na decisão da ADPF 186. Tal julgamento evidencia a transferência para o Poder Judiciário das questôes da moralidade pública, em parte pela inaptidão dos outros dois Poderes. Ao decidir sobre as cotas para acesso ao Ensino Superior os juízes da Suprema Corte atuaram como importantes guardióes das promessas do pacto democrático, representadas por direitos positivados em textos normativos que encontram dificuldade de se concretizar na arena política tradicional, não sem o risco de se converterem no guardião da moral.

De modo que a pesquisa conclui por um perfil teórico ativista de teor hermenêutico de fundo fenomenológico no julgamento da ADPF 186, embora não encontre nela uma reflexão, coesão epistemológica ou identificação explícita de marcos teóricos a esse respeito.

\section{Referências}

AGRA, W. M. A reconstrução da legitimidade do Supremo Tribunal Federal: a densificação da jurisdição constitucional brasileira. Rio de Janeiro: Forense, 2005. APPIO, E. Controle judicial das políticas públicas no Brasil. Curitiba: Juruá, 2007. BARROSO, L. R. Judicialização, ativismo judicial e legitimidade democrática. Anuario Iberoamericano de Justicia Constitucional, Madrid, 
n. 13, p. 17-32, 2009. Disponível em: <https://dialnet.unirioja.es/servlet/ articulo? codigo $=5124286 \&$ orden $=0 \&$ info $=$ link $>$. Acesso em: 30 set. 2016.

BARZOTTO, L. F. Justiça social - gênese, estrutura e aplicação de um conceito. Revista Jurídica Virtual, Brasília, v. 5, n. 48, maio 2003. Disponível em: <https:// revistajuridica.presidencia.gov.br/index.php/saj/article/view/747/738>. Acesso em: 15 set. 2016 .

BERNARDINO, J. Ação afirmativa e a rediscussão do mito da democracia racial no Brasil. Estudos Afro-Asiáticos, Brasília, v. 24, n. 2, p. 247-273, 2002. Disponível em: <http://www.scielo.br/scielo.php?script=sci_arttext\&pid=S0101546X2002000200002>. Acesso em: 18 out. 2016.

BRITO, C. A. A. F. Voto. Arguição de Descumprimento de Preceito Fundamental n. 186 - Inteiro teor do acórdão. Brasília, 2012. Disponível em: <http://redir.stf. jus.br/paginadorpub/paginador.jsp?docTP=TP\&docID=6984693>. Acesso em: 2 set. 2016.

BUCCI, M. P. D. O conceito de política pública em direito. In: BUCCI, M. P. D. (Org.). Políticas públicas: reflexões sobre o conceito jurídico. São Paulo: Saraiva, 2006, p. 1-47.

CARNEIRO, W. A. Hermenêutica jurídica heterorreflexiva: uma teoria dialógica do direito. Porto Alegre: Livraria do Advogado, 2011.

CECCHIN, A. J. Açôes afirmativas: inclusão social das minorias. Rev. Ciên. Jur. e Soc. da Unipar, Umuarama. v. 9, n. 2, p. 325-354, 2006. Disponível em: <http:// www.dcoms.unisc.br/portal/upload/com_arquivo/acoes_afirmativasinclusaosocialdasminorias.pdf>. Acesso em: 15 set. 2016.

CITTADINO, G. Poder judiciário, ativismo judiciário e democracia. ALCEU, Rio de Janeiro, v. 5, n. 9, p. 105-113, jul./dez. 2004. Disponível em: <http:// revistaalceu.com.puc-rio.br/media/alceu_n9_cittadino.pdf>. Acesso em: 30 set. 2016.

CRUZ, G. G. M. Arguição de Descumprimento de Preceito Fundamental: lineamentos básicos e revisão crítica no direito constitucional brasileiro. São Paulo: Malheiros, 2011.

CUNHA JÚNIOR, D. Controle de Constitucionalidade: teoria e prática. 8. ed. rev. amp. atual. Salvador: Juspodivm, 2016. 
DWORKIN, R. Levando os direitos a sério. 2. ed. São Paulo: Martins Fontes, 2007. DWORKIN, R. O império do direito. São Paulo: Martins Fontes, 1999. DWORKIN, R. O império do direito. São Paulo: Martins Fontes, 2014. FOUCAULT, M. A ética do cuidado de si como prática da liberdade. In: MOTTA, M. B. (Org.). Ética, sexualidade e política. 2. ed. Rio de Janeiro: Forense Universitária, 2006.

FUX, L. Voto. Arguição de Descumprimento de Preceito Fundamental n. 186 Inteiro teor do acórdão. Brasília, 2012. Disponível em: <http://redir.stf.jus.br/ paginadorpub/paginador.jsp?docTP=TP\&docID=6984693>. Acesso em: 2 set. 2016.

GADAMER, H.-G. Verdade e método I: traços fundamentais de uma hermenêutica filosófica. Tradução: Flávio Paulo Meuer. 15. ed. Petrópolis: Vozes, 2015.

GARAPON, A. O juiz e a democracia: o guardiáo das promessas. 2. ed. Rio de Janeiro: Revan, 2001.

GOMES, J. B. B.; SILVA, F. D. L. L. As açôes afirmativas e os processos de promoção da igualdade efetiva. In: SEMINÁRIO INTERNACIONAL - AS MINORIAS E O DIREITO, 2002, Brasília, DF. Anais [...]. Brasília, DF: Conselho da Justiça Federal, 2002. Disponível em: <http://sites.multiweb.ufsm. br/afirme/docs/Artigos/var02.pdf>. Acesso em: 13 ago. 2016.

HEIDEGGER, M. Ser e tempo: parte I. 15. ed. Petrópolis: Vozes, 2005.

HOFLING, E. M. Estado e políticas (públicas) sociais. Cad. CEDES, Campinas, 2001, v. 21, n. 55, p. 30-41. Disponível em: <http://www.scielo.br/pdf/ccedes/ v21n55/5539.pdf>. Acesso em: 11 set. 2016.

IBGE - INSTITUTO BRASILEIRO DE GEOGRAFIA E ESTATÍSTICA. Sintese de indicadores sociais: uma análise das condiçôes de vida da população brasileira - 2016. Rio de Janeiro: IBGE, 2016. Disponível em: <http://biblioteca. ibge.gov.br/visualizacao/livros/liv98965.pdf>. Acesso em: 28 maio 2017.

JACCOUD, L. O combate ao racismo e à desigualdade: o desafio das políticas públicas de promoção da igualdade racial. In: THEODORO, M. (Org.). As políticas públicas e a desigualdade racial no Brasil 120 anos após a aboliçâo. Brasil: Ipea, 2008, p. 45-64.

JOHNSON, O. A. Explicando a extinção do partido dos panteras negras: o papel dos fatores internos. CADERNO CRH, Salvador, n. 35, p. 93-125, jan./jun. 
2002. Disponível em: <https://www.portalseer.ufba.br/index.php/crh/article/ view/18631/12005>. Acesso em: 17 abr. 2017.

LEWANDOWSKI, R. Voto. Arguição de Descumprimento de Preceito Fundamental n. 186 - Inteiro teor do acórdão. Brasília, 2012. Disponível em: <http://redir.stf. jus.br/paginadorpub/paginador.jsp?docTP=TP\&docID=6984693>. Acesso em: 2 set. 2016.

MENDES, G. F. Voto. Arguição de Descumprimento de Preceito Fundamental n. 186 - Inteiro teor do acórdão. Brasília, 2012. Disponível em: <http://redir.stf.jus. br/paginadorpub/paginador.jsp?docTP=TP\&docID=6984693>. Acesso em: 2 set. 2016.

MOEHLECKE, S. Ação afirmativa: história e debates no Brasil. Cadernos de Pesquisa, n. 117, p. 197-217, nov. 2002. Disponível em: <http://www.scielo.br/ $\mathrm{pdf} / \mathrm{cp} / \mathrm{n} 117 / 15559>$. Acesso em: 11 set. 2016.

OLIVEN, A. C. Açôes afirmativas, relaçôes sociais e politica de cotas nas universidades: uma comparação entre os Estados Unidos e o Brasil. Educação, Porto Alegre, n. 1, p. 29-51 jan./abr. 2007. Disponível em: <http://revistaseletronicas.pucrs.br/ojs/ index.php/faced/article/view/539>. Acesso em: 3 abr. 2017.

PELUSO, A. C. Voto. Arguição de Descumprimento de Preceito Fundamental n. 186 - Inteiro teor do acórdão. Brasília. Disponível em: <http://redir.stf.jus.br/ paginadorpub/paginador.jsp?docTP=TP\&docID=6984693>. Acesso em: 2 set. 2016.

PIOVESAN, F. Açóes afirmativas da perspectiva dos direitos humanos. Cadernos de Pesquisa, São Paulo, v. 35, n. 124, p. 43-55, jan./abr. 2005. Disponível em: <http://www.scielo.br/pdf/cp/v35n124/a0435124.pdf>. Acesso em: 13 ago. 2016.

ROCHA, C. L. A. Voto. Arguição de Descumprimento de Preceito Fundamental n. 186 - Inteiro teor do acórdão. Brasília, 2012. Disponível em: <http://redir.stf. jus.br/paginadorpub/paginador.jsp?docTP=TP\&docID=6984693>. Acesso em: 2 set. 2016.

WEBER, R. M. P. Voto. Arguição de Descumprimento de Preceito Fundamental n. 186 - Inteiro teor do acórdão. Brasília, 2012. Disponível em: <http://redir.stf. jus.br/paginadorpub/paginador.jsp?docTP=TP \&docID=6984693>. Acesso em: 2 set. 2016.

SARLET, I. W. Neoconstitucionalismo e influência dos direitos fundamentais no 
direito privado: algumas notas sobre a evolução brasileira. Civilistica.com - Revista Eletrônica de Direito Civil, a. 12. n. 1, 2012. Disponível em: <http://civilistica. com/wp-content/uploads/2015/02/Sarlet-civilistica.com-a.-1.n.1.2012.pdf>. Acesso em: 3 mar. 2019.

STEIN, E. Compreensão e finitude: estrutura e movimento da interrogação heideggeriana. Ijuí: Unijuí, 2001.

STRECK, L. L. Jurisdição constitucional e hermenêutica: uma nova crítica do direito. Porto Alegre: Livraria do Advogado, 2002. 


\title{
ANIMAIS NÂO HUMANOS: DIREITO À VIDA E À DIGNIDADE
}

\author{
Valmir Cesar Pozzetti ${ }^{1}$ \\ Universidade do Estado do Amazonas (UEA) \\ Universidade Federal do Amazonas (UFAM) \\ Elizabeth Beatriz Rodrigues Braga ${ }^{2}$ \\ Universidade Federal do Amazonas (UFAM) \\ Artigo recebido em: 03/07/2019. \\ Artigo aceito em: 28/08/2019.
}

\section{Resumo}

O objetivo desta pesquisa foi analisar o ções especiais e protetivas aos animais uso de animais no cotidiano humano e não humanos e que se faz necessário verificar de que forma o poder públi- a aplicação na íntegra do disposto na co, por meio de suas atribuiçôes legais, Declaração dos Direitos dos Animais conseguiria garantir a proteção devida aos animais não humanos. A metodologia utilizada foi o método dedutivo; quanto aos meios, a pesquisa foi a bibliográfica e, quanto aos fins, qualitativa. A conclusão a que se chegou foi a de que é necessária a edição de legislada Unesco, pois ela garante aos animais direitos básicos como descanso, direito à alimentação e a restrição aos trabalhos forçados.

Palavras-chave: dignidade animal; direito; fauna; filosofia; vida.

\section{NON-HUMAN ANIMALS: RIGHT TO LIFE AND DIGNITY}

\section{Abstract}

The objective of this research was to analyze animal use in human daily life and to verify how the public power, through its legal attributions, could guarantee the protection due to nonhuman animals. The methodology used in this research was

\footnotetext{
1 Doutor e Mestre em Direito Ambiental pela Université de Limoges (UNILIM), com título revalidado pela Universidade Federal de Pernambuco (UFPE). Professor -adjunto do Mestrado em Direito Ambiental da UEA. Professor adjunto da UFAM. ORCID: http://orcid.org/0000-0002-3738-4891 / E-mail: v_pozzetti@hotmail.com

2 Bacharelanda do Curso de Direito da UFAM. Jovem cientista do PIBIC. E-mail: elizabethbrodriguesbraga@gmail. com
} 
the deductive method; as to the means the research was the bibliographical and as for the purposes, qualitative. The conclusion reached is that it is necessary to issue legislation that is especially protective of non-human animals and that the full application of the provisions of the
Unesco Animal Rights Declaration is necessary, since it guarantees animals basic rights such as rest, the right to food and the restriction of forced labor.

Keywords: dignity; law; fauna;

philosophy; life.

\section{Introduçáo}

A vida na Terra depende de todos os seres vivos, pois cada um desempenha sua função essencial. Nesse panorama, a vida e a diversidade animal são muito importantes para a manutenção do equilíbrio do planeta. O próprio ser humano também é um animal que pode ser classificado seguindo os critérios da taxonomia moderna.

Mesmo assim, o ser humano tenta incansavelmente declarar-se o ser superior do planeta, por ser a única espécie racional e, em decorrência disso, não são raras as vezes que subjuga as outras formas de vida, em especial os animais não humanos.

Comumente esses animais sofrem diversas agressóes: são maltratados, envenenados, levados a trabalhar até a exaustáo, obrigados a participar de brigas em rinhas de galo e de cães - algumas vezes em modalidades que só terminam quando há a morte de um dos oponentes - entre outras crueldades. Por serem vítimas de pessoas mal-intencionadas, principalmente durante o treinamento para essas rinhas, e incapazes de expressar sua vontade, esses animais tornam-se extremamente vulneráveis a ataques de violência e repressão.

O objetivo desta pesquisa é analisar a vulnerabilidade e propor a conservação da vida e a dignidade dos animais não humanos. Pretende-se também demonstrar uma visáo crítica ao antropocentrismo jurídico, paradigma que considera o ser humano o centro do universo das avaliaçóes de relaçóes humanas. Isto significa dizer, portanto, que as demais espécies do planeta existem com o único propósito de servi-lo, o que não condiz com a realidade, pois há uma interdependência entre as diversas espécies.

Esse pensamento antropocentrista implica validar a exploração animal indisciplinada, que já trouxe consequências: inúmeras espécies extintas ou com risco de extinção e poucos esforços para a recuperação dessas espécies, que tem espaço legitimado para ocupar o planeta tanto quanto o ser humano. Eis, portanto, a importância da pesquisa. 
A problemática que motiva esse estudo é: de que forma o direito pode contribuir para que os animais não humanos possam ser respeitados em sua integralidade, concedendo-lhes dignidade individual?

Por meio da pesquisa, justifica-se que a vida no planeta depende da conscientizaçáo humana acerca do respeito perante os demais seres vivos, pois, caso contrário, todos sucumbirão.

Para alcançar os objetivos propostos, analisar-se-á os diferentes aspectos da exploraçấo animal sob o viés da filosofia, das leis brasileiras e estrangeiras para tentar propor uma melhor maneira de usufruir dessa modalidade. A solução seria não apenas seguir rigorosamente a Declaração Universal dos Direitos dos Animais proposta pela Unesco, mas também redigir legislaçóes nacionais inspiradas nela, tal como estão dispostas as diretivas da União Europeia que tratam da utilização de animais nos países que fazem parte de seu bloco econômico.

Com relação aos métodos de pesquisa, será utilizado o método dedutivo; quanto aos meios, a pesquisa será bibliográfica e, quanto aos fins, qualitativa.

\section{Elementos protetivos aos animais não humanos}

$\mathrm{O}$ respeito à vida e à integridade dos animais ateve-se, inicialmente, ao campo moral e religioso. Há, no Código de Hamurabi, orientaçôes para respeitar a integridade deles e penas que iam desde multa até a pena de morte para os transgressores.

\subsection{Da proteção bíblica}

O ser humano é um ser racional e, como tal, coloca-se na própria legislação como o mais importante. Segundo Aristóteles, os humanos se diferenciam dos demais seres por serem dotados de razão, sendo definidos como "animais políticos".

Desde os povos antigos já se constatava a importância dos animais como sujeitos de direito. Torna-se relevante destacar o documento central para a fé de grande parte da população mundial, a Bíblia, no que diz respeito aos animais e à preocupação com o bem-estar deles.

Na Bíblia, Deus providenciou que os animais tivessem as condiçóes mínimas de subsistência: água, comida, descanso e proteção contra ferimentos: "Se encontrares o boi do teu inimigo, ou o seu jumento, desgarrado, sem falta lho reconduzirás. Se vires o jumento, daquele que te odeia, caído debaixo da sua carga, deixarás pois de ajudá-lo? Certamente o ajudarás a levantá-lo” (Êxodo, 23:4-5). 
Nota-se que, mesmo sendo necessário aos israelitas consumir a carne animal para a própria subsistência, seu livro sagrado náo incentivava a prática de maus-tratos. Muito pelo contrário: há diversas passagens bíblicas nas quais é ensinado que o homem deve ter consideração pelas outras espécies presentes na terra, conforme se destaca em Deuteronômio, 22:1-4:

Vendo extraviado o boi ou ovelha de teu irmão, não te desviarás deles; restituí-los-á sem falta a teu irmão. E se teu irmão não estiver perto de ti, ou não o conheceres, recolhê-los-ás na tua casa, para que fiquem contigo, até que teu irmão os busque, e tu lhos restituirás. Assim também farás com o seu jumento, e assim também farás com as suas roupas; assim farás também com toda a coisa perdida, que se perder de teu irmão, e tu achares; não te poderás omitir. Se vires um jumento que é de teu irmão, ou o seu boi, caídos no caminho, não te desviarás deles; sem falta o ajudarás a levantá-los.

Mesmo a Bíblia trazendo o consenso de que os animais são vistos como propriedade, dando-lhes tratamento semelhante ao que é dado a roupas e outras coisas perdidas, ainda assim merece destaque o fato de que a orientação seja de guardar os bois ou jumentos consigo e ir atrás do verdadeiro dono. Isso implica dizer que aquele que os achou deveria ter os cuidados necessários: os animais terão água, comida e espaço necessário dentro da propriedade daquele que achou para sua subsistência e posterior devoluçáo ao proprietário. $\mathrm{Na}$ época, os animais eram criados mais para fins de alimentação e transporte, por isso não se visualizava outro tratamento que não fosse o de um parceiro de trabalho.

\subsection{Proteção no Código de Hamurabi}

O Código de Hamurabi foi editado pelo rei da Babilônia e seu reinado, em XVIII a.C, foi tido como exemplo de sabedoria e reflexão. Esse código, que ele editou e que leva seu nome, é o conjunto de leis considerado uma das fontes mais antigas do Direito.

O Código de Hamurabi foi talhado em uma grande rocha de diorito negro e contém leis penal, cível e alguns de seus artigos referentes a um arcaico direito do trabalho. $\mathrm{O}$ código apenas registrava a tradição das leis passadas oralmente. $\mathrm{O}$ direito na época era consuetudinário, ou seja, oriundo dos costumes de determinada sociedade (KINSELLA, 2013).

Em se tratando dos artigos que versam sobre a reparação por danos materiais - comum no Direito Civil - o Código de Hamurabi dispóe de inúmeras 
formas de defesa dos interesses dos proprietários, entre eles donos de bois, asnos, ovelhas e demais animais domésticos que os povos mesopotâmicos criavam para futuro abate, garantidor de sua subsistência.

Ou seja, havia, mesmo que indiretamente, proteção aos animais no sentido de resguardar sua integridade física antes que fosse totalmente necessária à sua morte, sob penas pecuniárias e, em alguns casos, a morte, segundo Ribeiro (2012, p. 23), estaria no art. $7^{\circ}$ do Código de Hamurabi, com a seguinte redaçáo:

Se alguém, sem testemunhas ou contrato, compra ou recebe em depósito ouro ou prata ou um escravo ou uma escrava, ou um boi ou uma ovelha, ou um asno, ou outra coisa de um filho alheio ou de um escravo, é considerado como um ladrão e morto.

Algumas vezes, segundo Ribeiro (2012, p. 24) "a pena de morte era aplicada subsidiariamente em casos de roubo ou furto, quando o infrator não tinha condiçôes de arcar com as indenizaçôes decorrentes do seu comportamento ilícito”. Tal disposição pode ser encontrada na sessão do Código de Hamurabi que trata dos crimes de furto, roubo e reinvindicação de móveis:

Art. $8^{\circ}$ Se alguém rouba um boi ou uma ovelha ou um asno ou um porco ou um barco, se a coisa pertence ao Deus ou a Corte, ele deverá dar trinta vezes tanto; se pertence a um liberto, deverá dar dez vezes tanto; se o ladrão não tem nada para dar, deverá ser morto.

É importante destacar que esses excessos, como a pena de morte e a lei de Taliáo - olho por olho, dente por dente - aplicadas pelo código de Hamurabi devia-se à noção de exterminar os impuros e a retaliação, numa tentativa de dar justiça à vítima e à sua família.

\subsection{Boas práticas de bem-estar animal}

O Ministério da Agricultura, Pecuária e Abastecimento (Mapa) estabelece por meio da Instrução Normativa (IN) n. 56, de 2008, que os animais considerados de produção, tenham, enquanto viverem, garantidos o seu bem-estar:

Art. $2^{\circ}$. todo aquele cuja finalidade da criação seja a obtenção de carne, leite, ovos, lá, pele, couro e mel ou qualquer outro produto com finalidade comercial. [...] todo aquele considerado animal de produçáo ou aqueles cuja finalidade seja esportiva e que gere divisas, renda e empregos, mesmo que sejam também considerados como animais de produção (BRASIL, 2008). 
Essa IN n. 56/2008, estabelece um rol de princípios para a criação de tais animais, visando assegurar-lhes o bem-estar:

Art. $3^{\circ}[\ldots]$

I - Proceder ao manejo cuidadoso e responsável nas várias etapas da vida do animal, desde o nascimento, criação e transporte;

II - Possuir conhecimentos básicos de comportamento animal a fim de proceder ao adequado manejo;

III - proporcionar dieta satisfatória, apropriada e segura, adequada às diferentes fases da vida do animal;

IV - Assegurar que as instalaçóes sejam projetadas apropriadamente aos sistemas de produção das diferentes espécies de forma a garantir a proteçấo, a possibilidade de descanso e o bem-estar animal;

$\mathrm{V}$ - Manejar e transportar os animais de forma adequada para reduzir o estresse e evitar contusōes e o sofrimento desnecessário; VI - Manter o ambiente de criação em condiçôes higiênicas (BRASIL, 2008).

A IN n. 56/08 tem por objetivo assegurar a tutela garantida pelo Estado, na Constituição Federal de 1988:

Art. 225. Todos têm direito ao meio ambiente ecologicamente equilibrado, bem de uso comum do povo e essencial à sadia qualidade de vida, impondo-se ao Poder Público e à coletividade o dever de defendê-lo e preservá-lo para as presentes e futuras gerações.

[...]

VII - proteger a fauna e a flora, vedadas, na forma da lei, as práticas que coloquem em risco sua função ecológica, provoquem a extinçấo de espécies ou submetam os animais a crueldade.

De acordo com o art. 225, VII, assegura-se a utilização de animais para fins relativos a interesses humanos, porém, há vedação expressa da extinção de espécies e das práticas que os submetem a crueldade.

\subsection{Tutela do Estado}

Durante a Era Vargas - período entre 1930 e 1945 governado por Getúlio Vargas e que compreende a "Segunda República" e o "Estado Novo" - houve a criação do Decreto n. 24.645/1934, que estabelecia medidas de proteção à fauna, coibindo abusos e crueldades: 
Art. $3^{\circ}[\ldots]$

I - praticar ato de abuso ou crueldade em qualquer animal;

II - manter animais em lugares anti-higiênicos ou que lhes impeçam a respiração, o movimento ou o descanso, ou os privem de ar ou luz;

III - obrigar animais a trabalhos excessivos ou superiores às suas forças e a todo ato que resulte em sofrimento para deles obter esforços que, razoavelmente, não se lhes possam exigir senáo com castigo;

IV - golpear, ferir ou mutilar, voluntariamente, qualquer órgão ou tecido de economia, exceto a castração, só para animais domésticos, ou operaçôes outras praticadas em benefício exclusivo do animal e as exigidas para defesa do homem, ou interesse da ciência;

$\mathrm{V}$ - abandonar animal doente, ferido, extenuado ou mutilado, bem como deixar de ministrar-lhe tudo que humanitariamente se lhe possa prover, inclusive assistência veterinária;

VI - não dar morte rápida, livre de sofrimento prolongados, a todo animal cujo extermínio seja necessário para consumo ou não;

VII - abater para o consumo ou fazer trabalhar os animais em período adiantado de gestação;

VIII - atrelar, no mesmo veículo, instrumento agrícola ou industrial, bovinos com equinos, com muares ou com asininos, sendo somente permitido o trabalho em conjunto a animais da mesma espécie; [...] (BRASIL, 1934).

Tal legislação mostra-se bastante desenvolvida para a época, visto que só houve um consenso mundial quanto a princípios gerais para a relação humano-animal em 1978, com a Declaração Universal dos Direitos dos Animais proclamada pela Unesco em sessão na cidade de Bruxelas.

Neste sentido, Rodrigues (2003, p. 55) esclarece:

[...] Tanto a vida do homem quanto a do animal possuem valor. A vida é valiosa independentemente das aptidóes e pertinências do ser vivo. Não se trata de somente evitar a morte dos animais, mas de dar oportunidade para nascerem e permanecerem protegidos. A gratidáo e o sentimento de solidariedade para com os animais devem ser valores relevantes na vida do ser humano [...]. 
O legislador aproxima-se, portanto, da tendência mundial atual: a de classificação de animais como sujeitos de direito, como seres dotados de personalidade e dignidade.

É o que podemos extrair das palavras de Gomes \& Chalfun (2006, p. 863):

Os direitos fundamentais são intrínsecos ao homem, por sua condiçâo de ser vivo. Direito à vida digna, alimentação, de não sofrer maus-tratos ou violência, independentemente de pactos ou racionalidade, de manifestação de vontade, tanto assim que bebês, alienados mentalmente, doentes em estado vegetativo ou coma, não manifestam vontade, no entanto, têm direitos fundamentais a serem respeitado, de modo que não há como ser diferente com os animais.

Dessa forma, verifica-se que a doutrina já vem se posicionando no sentido de que os animais não humanos têm direito a uma vida digna.

\section{Direito à vida e à dignidade dos animais náo humanos}

O consumo de animais para a alimentação, a exploração de sua força bruta e o uso em testes de cosméticos estáo impregnados na cultura humana. Porém, com o progresso científico atual já é possível a substituição de peles de animais em roupas, trocando por tecidos sintéticos e até a substituição de fontes de proteínas e vitaminas de origem animal pelas de origem vegetal. Não é fácil rever os hábitos alimentares e alterar o uso animal nos diversos setores da vida humana.

O reconhecimento de animais como sujeitos que têm direitos e cujas vida e dignidade merecem ser protegidas, apesar de sua natureza desprovida de razáo, pode ser o início para as mudanças na exploração desmedida da vida animal.

O caminho possível para essas mudanças é considerar o bem-estar dos animais, mesmo que eles sejam utilizados para interesses humanos

Todos os seres, portanto, devem ter seu bem-estar assegurado para ter direito à vida com dignidade. Mesmo o abate animal voltado para o consumo humano deve ser um processo digno, sem maus-tratos e sem dor desnecessária.

\subsection{Proteção à vida animal}

Um dos deveres estabelecidos a todos os cidadãos na Constituição Federal é garantir o direito ao meio ambiente ecologicamente equilibrado, considerando-o como bem de uso comum do povo e essencial à qualidade de vida: 
Art. 225. Todos têm direito ao meio ambiente ecologicamente equilibrado, bem de uso comum do povo e essencial à sadia qualidade de vida, impondo-se ao Poder Público e à coletividade o dever de defendê-lo e preservá-lo para as presentes e futuras geraçóes.

O planeta Terra é formado por uma grande diversidade biológica, tais como plantas, animais e matérias-primas inorgânicas, ar, água e solo.

Neste sentido, a Constituição de 1988 não deixa de considerar os animais como importantes neste aspecto.

Percebendo a necessidade deles na manutenção da vida humana e entendendo que não há necessidade de formas cruéis ou violentas no uso da exploração desses animais, seja para fins de subsistência, econômicos ou apenas domésticos, como animais de estimação, a Constituição de 1988 visa proibir as práticas cruéis e as que colocam em risco a fauna e a flora.

Portanto, ao proibir essas práticas, o legislador impóe que o administrado utilize os meios suficientes para a exploração necessária com finalidade econômica ou de subsistência, evitando atividades com caráter de crueldade ou que possam provocar o extermínio de espécies. A flora pode ser recuperada com reflorestamento, diferentemente das formas de vida animais, que náo podem ser recuperadas por meios artificiais. Uma vez que a espécie é extinta, não é possível recriá-la e introduzi-la novamente na área afetada. Por esse motivo os esforços visando a conservação da vida são tão importantes.

\subsection{Direito à existência}

No art. 225 da Constituição Federal, o legislador positivou alguns princípios gerais da Declaraçáo dos Direitos dos Animais redigida pela Unesco, em 1978 a fim de assegurar a existência e o respeito de animais não humanos, reconhecendo-os também como seres que têm direitos:

No entendimento de Dias (2000, p.333):

Esse documento é um convite para o homem renunciar à sua atual conduta de exploraçáo dos animais e, progressivamente, ao seu modo de vida e ao antropocentrismo, para ir de encontro ao "biocentrismo". Por essa razão, representa uma etapa importante na história da evolução do homem. 


\subsection{Mecanismo de proteçáo: uso de selos cruelty free}

Tendo em vista o número de casos de crueldade animal, as associaçóes de defesa dos animais instauraram procedimentos para identificar empresas que se comprometem a oferecer ao consumidor produtos isentos dessa exploração.

Para isso, houve a criação do selo cruelty free, que, em tradução livre, significa "sem crueldade". É um termo muito utilizado pelo movimento de direitos dos animais e é aplicável a produtos ou atividades que não causem sofrimento, dano ou morte aos animais. A indústria de cosméticos, ao longo do tempo, utilizou-se de animais, em grande escala, para testar seus produtos. Assim, produtos cujas etapas de aprovação incluírem testes em animais não recebem esse selo, visto os sofrimentos que eles sofrerão no processo.

Há dois grupos dentro do debate da experimentação animal: os que defendem a continuação dos testes (para verificar ocorrência de alergia na boca, nos olhos e na pele, por exemplo) e os que são contra esses procedimentos em animais, tendo em vista que há formas alternativas de se conduzir tais pesquisas e obter resultados equivalentes.

Neste sentido, Andre e Velasquez (2015, p. 1, grifo nosso) pontuam:

[...] ativistas do bem-estar animal defendem sua posição ao contraporem-se à alegaçáo de que deter experimentos com animais dolorosos acabaria com o progresso científico, com conseqüências danosas para a sociedade. Muita experimentação animal, dizem eles, é realizada por mera curiosidade e tem pouco ou nenhum mérito científico. Os animais estão famintos, chocados, queimados e envenenados enquanto os cientistas procuram algo que possa trazer algum benefício humano. Em um caso, camundongos bebês tiveram suas pernas cortadas para que os experimentadores pudessem observar se eles aprenderiam a se limpar com seus cotos. Em outro, os ursos polares foram submersos em um tanque de petróleo bruto e água salgada para ver se eles viveriam. E, para aquelas experiências que têm mérito, existem muitas alternativas náo-animais. É apenas por puro hábito ou facilidade que os cientistas continuam a infligir dor aos animais quando, de fato, existem alternativas. $\mathbf{E}$, onde não existem alternativas, a tarefa moral da ciência é descobri-las.

Com a crescente conscientizaçáo da populaçáo sobre a desnecessidade de exploraçáo animal em testes que lhes causem sofrimento, o mercado consumidor busca identificar marcas que utilizam métodos sem cobaias. 
Para isso, algumas empresas investem em meios alternativos. Exemplo disso é o mecanismo desenvolvido pelo grupo Boticário conhecido como "pele 3D", método reconhecido pela ANVISA e pelo CONCEA.

A pele 3D é uma tecnologia capaz de reproduzir em condiçôes de laboratório a pele humana. Para a elaboração dessa pele sintética, são utilizadas células isoladas a partir de tecido humano descartado de cirurgias plásticas, nos casos em que há o consentimento do doador para esse fim e aprovação da instituição no Comitê de Ética e Pesquisa.

Segundo o grupo Boticário (DESCUBRA..., 2017) "são desenvolvidas derme e epiderme, nas quais é possível realizar diversos testes em uma mesma unidade de pele durante 7 dias, em vez de 72 horas, assim como é com a pele comum, se fosse utilizada para os mesmos fins.

Essa nova tecnologia evita procedimentos nos quais a indústria expóe os animais a situaçóes de sofrimento e, também, reduz os testes em humanos.

\section{4 $\mathrm{O}$ caso Dalva Lina: afronta à existência}

Mesmo com a proteçáo dada por lei, ainda existem casos de afronta à existência dos animais e esses crimes são considerados de menor potencial ofensivo, de menor relevância. Tais açôes são julgadas pelos Juizados Especiais Criminais, de acordo com a Lei n. 9.099/95.

A Agência de Notícias de Direitos Animais (ANDA), é uma agência de notícias criada para a propagação de relatos pertinentes à defesa dos direitos animais, a primeira agência jornalística do gênero no Brasil. O trecho a seguir foi retirado de uma reportagem de seu site, publicada em 2018:

Condenada a 17 anos, 6 meses e 26 dias de reclusão em regime semiaberto pela morte de 37 cáes e gatos em 2012, e foragida desde o ano passado, Dalva Lina da Silva, de 48 anos, que ficou conhecida como "a matadora de animais", foi finalmente presa. Uma pessoa a reconheceu dentro de uma agência do Banco do Brasil e chamou a Polícia Militar que a levou para o $16^{\circ}$ DP na Vila Clementina, em SP, sendo posteriormente transferida para a carceragem feminina do $89^{\circ}$ DP, no Portal do Morumbi, na zona Sul da cidade, onde deve aguardar a decisão sobre onde cumprirá a pena.

O “Caso Dalva” é inédito. É a maior sentença já proferida envolvendo crime de maus-tratos a animais. Uma grande conquista 
conseguida depois de uma dura maratona em busca de provas. "Essa decisão é uma grande vitória e a maior do mundo. Em 2016 uma pessoa foi condenada a 15 anos nos Estados Unidos por maus-tratos contra animais. Com a sentença da Dalva reformada, creio que essa condenaçáo é a maior pena que se tem notícia no mundo”, disse a promotora Vania Tuglio, do Grupo Especial de Combate aos Crimes Ambientais (GECAP).

Apesar de ter sido condenada pelo assassinato 37 de cáes e gatos, milhares de animais de animais [sic] recolhidos das ruas ou entregues à Dalva simplesmente tiveram suas vidas arrancadas com muito sofrimento, dor e violência ao longo de 10 anos, numa casa no bairro da Vila Mariana, em SP, onde ela morava. Dentre eles, muitos filhotes ou colônias inteiras de gatos retirados de estabelecimentos públicos, já castrados e vacinados, entregues por protetores que acreditavam que Dalva também fosse uma defensora de animais. Não era. E pior: era uma assassina em série que utilizava um método doloroso para matar os animais num obscuro quartinho em sua própria casa que tinha manchas de sangue nas paredes (CHUECCO, 2018).

Casos como os de Dalva não são difíceis de encontrar. No entanto, sua pena é histórica: 17 anos, 6 meses e 26 dias e se deu ao fato de a acusação ter provado a morte de 37 cáes e gatos.

A ação de Dalva se arrastava há mais de 10 anos e estima-se que mais de mil animais passaram por suas mãos, motivadas não somente pelo prazer de matar, mas também pela sensação de impunidade. Hoje, ela cumpre pena em regime semiaberto.

A redação antiga da Lei n. 9.605/98, art. 32, caput, dava margem à impunidade. Ao ser classificado como crime de menor potencial ofensivo, o réu respondia pela Lei n. 9099/95, que em seu art. 62 dita os princípios do Juizado Especial Criminal.

Neste sentido, Dias (2000, p. 37, grifo nosso) esclarece que:

Se cotejarmos os direitos de uma pessoa humana com os direitos do animal como indivíduo ou espécie, constatamos que ambos têm direito à defesa de seus direitos essenciais, tais como o direito à vida, ao livre desenvolvimento de sua espécie, da integridade de seu organismo e de seu corpo, bem como o direito ao não sofrimento. Sob o ponto de vista ético e científico, é fácil justificar a personalidade do animal. [...] Se quisermos comparar o valor 
de uma vida com outra, teremos que começar por discutir o valor da vida em geral.

Ora, qual é o valor da vida? Essa classificação do crime de maus-tratos aos animais abre brecha para injustiça: nada que o acusado faça trará aquela vida de volta. Portanto, ele deve responder por pena mais severa para inibir a prática do crime.

\section{Exploração dos animais náo humanos}

As necessidades humanas são infinitas e os recursos, escassos, se utilizados de forma desregrada ou intolerante. Durante a história da humanidade, foi construído um senso filosófico majoritário de superioridade sobre o restante dos animais, igualmente importantes para a manutenção do meio ambiente e o prolongamento da própria vida do homem.

Esse senso perpetuou-se na cultura, especialmente o criado por Aristóteles em sua obra $A$ política e por Descartes com a célebre frase "Penso, logo existo".

Em $A$ politica, Aristóteles (1.999, p. 14) afirma que:

O animal é como um escravo na sociedade, tendo como única finalidade servir ao homem, é um bem útil para alimentação, matéria-prima, uso diário, vestuário [...] com respeito aos demais animais é que só ele tem percepção do bem e do mal, do justo e do injusto e de outras qualidades semelhantes [...].

Aristóteles não defendia somente a servidão animal, mas também justificava a escravidáo. Pensamentos como a justificação da escravidão ou mesmo a manutenção de regimes de trabalho com condiçóes análogas à escravidão atuais são ideias abomináveis e já superadas pela sociedade, bem como pelo Direito. Essa ideia foi combatida e, graças a isso, todos os homens são considerados livres, mesmo que milhares de anos depois.

Segundo René Descartes, citado por Rocha (2004, p. 351), o "animal-máquina”, é um ser desprovido de alma, e Rocha esclarece:

A tese de que os animais são meros autômatos é sustentada por

Descartes basicamente em oposição à visão escolástica segundo a qual toda criatura viva é dotada de alma, o que implica numa hierarquia de faculdades, muitas vezes referida como as várias partes da alma - vegetativa, sensitiva e racional - que seriam responsáveis por todo comportamento das criaturas vivas sendo, no caso dos animais não-humanos, a parte sensitiva da alma a que 
apreenderia as sensaçôes. Segundo Descartes, essa explicação faz um apelo excessivo à alma para a explicaçáo dos comportamentos tanto dos homens (seus movimentos puramente fisiológicos) quanto dos animais não-humanos. Descartes insiste na tese segundo a qual tanto o comportamento corporal do homem quanto o comportamento do animal podem ser explicados em termos puramente mecânicos e, se é assim, não é necessário recorrer a conceitos como alma, forma substancial etc.

Tal pensamento legitima sua utilização como alimentos e em experimentos científicos, por exemplo, náo considerando o sofrimento no processo de abate ou preocupaçôes referentes a seu bem-estar.

Ao entender necessária a utilização animal para a subsistência humana por sua necessidade de proteínas, gorduras e demais nutrientes oriundos de alimentos como carne, leite e derivados, o legislador regula, na forma da lei, suas formas de exploração, dentre elas a para o consumo.

\subsection{Vedaçáo as práticas cruéis e violentas}

As práticas cruéis são aquelas que maltratam os animais expondo-os ao arbítrio daquele que o faz. Essa prática cruel pode ter ainda um grau de agressividade e de violência que expóe ainda mais o animal que não tem como se defender, como por exemplo, colocar fogo na cauda do animal, espanca-lo ao extremo quando ele está com medo e empaca, sem querer sair do lugar etc. Há outros casos como o de testar cosméticos nos olhos de coelhos, expondo à diversidade de reaçóes que o produto ode acarretar.

No Brasil, a utilização de animais é regulada PELA Constituição Federal de 1988:

\footnotetext{
Art. 225. [...]

$\$ 1^{\circ}$ Para assegurar a efetividade desse direito, incumbe ao poder público:

$[\ldots]$

VII - proteger a fauna e a flora, vedadas, na forma da lei, as práticas que coloquem em risco sua funçáo ecológica, provoquem a extinção de espécies ou submetam os animais a crueldade.
}

Essa vedação existe para que se tenha respeito e fraternidade na utilização/ colaboraçáo do animal, à fim de que essa seja feita de modo não cruel ou violento, coibindo os maus-tratos.

A Resolução n. 877/2008 do Conselho Federal de Medicina Veterinária, que 
versa sobre a padronização de procedimentos cirúrgicos em animais de produção - estes sendo definidos pela Instrução Normativa n. 56 do MAPA como: "procedimento cirúrgico é todo aquele cuja finalidade da criação seja a obtenção de carne, leite, ovos, lá, pele, couro e mel ou qualquer outro produto com finalidade comercial" (BRASIL, 2008) - e em animais silvestres é muito importante para se ilustrar o tipo de proteção dada pelo legislador na Constituição Federal.

Entre os grandes avanços trazidos pela resolução estão a desaprovação do uso exclusivo da contenção mecânica - que é o procedimento de amarrar o paciente no leito para que não se mexa - em cirurgias envolvendo animais náo humanos, sejam eles de produção ou silvestres em cativeiro.

Outro avanço sensível, agora com relação aos animais silvestres, é a Resolução n. 877/2008, que proíbe a realização de cirurgias consideradas mutilantes:

Art. $6^{\circ}$ As cirurgias realizadas em animais silvestres devem ser executadas de preferência em salas cirúrgicas ou em ambientes controlados e específicos para este fim, respeitado o disposto nos Artigos $2^{\circ}$ e $3^{\circ}$ desta Resolução. Fica proibida a realização de cirurgias consideradas mutilantes, tais como: amputaçáo de artelhos e amputação parcial ou total das asas, salvo exceção prevista no anexo 2 desta Resolução, conduzidas, com a finalidade de marcação ou que visem impedir o comportamento natural da espécie (CFMV, 2008).

Há apenas uma ressalva disposta no anexo 2 da Resolução n. 877/2008, que abre lacuna para tal comportamento:

A amputação parcial ou total das asas, pode ser realizada em famílias de aves cujo comportamento reprodutivo dispensa o voo ou que passam boa parte do tempo em atividade no solo e/ou na água, desde que mantidas em instituiçóes credenciadas pelo IBAMA ou órgão de competência similar, e que sejam previamente submetidas à anestesia e analgesia (CFMV, 2008).

Vê-se, portanto que a legislação brasileira cuidou de proteger os animais contra práticas cruéis e violentas.

\subsection{Vedação a maus-tratos}

A Lei n. 9.605/98, que versa sobre os crimes ambientais, proíbe expressamente os maus-tratos aos animais: 
Art. 32. Praticar ato de abuso, maus-tratos, ferir ou mutilar animais silvestres, domésticos ou domesticados, nativos ou exóticos: Pena - detenção, de três meses a um ano, e multa.

$\$ 1^{\circ}$ Incorre nas mesmas penas quem realiza experiência dolorosa ou cruel em animal vivo, ainda que para fins didáticos ou científicos, quando existirem recursos alternativos.

$\$ 2^{\circ}$ A pena é aumentada de um sexto a um terço, se ocorre morte do animal (BRASIL, 1998a, grifo nosso).

Segundo Barbosa (2018, p. 1) "em 2018, por conta da comoção nacional com o caso do cachorro que foi espancado e morto em uma unidade dos supermercados Carrefour em Osasco, foi aprovado o projeto de lei PLS n. 470/2018, que aumenta a pena do crime de maus-tratos aos animais para a pena mínima de um ano e máxima de quatro anos".

Esse tipo de crime, portanto, não será mais classificado como de menor potencial ofensivo, o que significa tratamento adequado à conduta, dado o grau de desaprovação da sociedade.

O Estado de Sáo Paulo, por meio da Lei n. 16.308/2016 dispóe de outro dispositivo legal para o infrator dos direitos a integridade dos animais:

Art. $1^{\mathrm{o}}$ - Fica proibida de obter a guarda do animal agredido, bem como de outros animais, toda pessoa que comprovadamente cometer maus-tratos contra animais domésticos que estejam sob sua guarda ou de outrem. Parágrafo único - O agressor poderá ter a guarda de um animal doméstico após o decurso de 5 (cinco) anos contados da agressão cometida, reiniciando-se a contagem do prazo se outra constatação de maus-tratos foi apurada.

O legislador paulista visa, com este dispositivo legal, descontinuar e reprimir ainda mais os maus-tratos aos animais com exemplar complemento na punição do art. 32 da lei de crimes ambientais.

\subsection{Vedação à exibição e práticas esportivas danosas}

O Estado de São Paulo tem uma legislação estadual protetora aos direitos animais, contando com um Código de Proteção aos Animais, a Lei n. 11.977/2005. Essa lei segue o raciocínio do Decreto n. 24.645/1934 de Getúlio Vargas.

O Estado de São Paulo, por si só, não tem a autoridade para declarar os animais como sujeitos de direito; porém, veda comportamentos que possam comprometer sua existência segundo a Lei n. 11.977/2005: 
Art. $2^{\circ}$ - É vedado:

I - ofender ou agredir fisicamente os animais, sujeitando-os a qualquer tipo de experiência, prática ou atividade capaz de causar-lhes sofrimento ou dano, bem como as que provoquem condições inaceitáveis de existência;

II - manter animais em local desprovido de asseio ou que lhes impeça a movimentaçáo, o descanso ou os privem de ar e luminosidade;

III - obrigar os animais a trabalhos excessivos ou superiores às suas forças e a todo ato que resulte em sofrimento, para deles obter esforços que não se alcançariam senão com castigo;

IV - não propiciar morte rápida e indolor a todo animal cujo abate seja necessário para consumo;

$\mathrm{V}$ - não propiciar morte rápida e indolor a todo animal cuja eutanásia seja recomendada;

VI - vender ou expor à venda animais em áreas públicas sem a devida licença de autoridade competente;

VII - enclausurar animais conjuntamente com outros que os molestem;

VIII - exercitar cães conduzindo-os presos a veículo motorizado em movimento;

IX - qualquer forma de divulgação e propaganda que estimule ou sugira qualquer prática de maus-tratos ou crueldade contra os animais.

Uma das justificativas para manter um animal selvagem em cativeiro é a exploração econômica, que pode ser exercida por zoológicos e por circos. Esta última, em especial, é prática ainda mais danosa, pois os animais são adestrados e se comportam de maneira distinta de como se comportariam em condiçôes naturais. Dessa forma, para os proteger, a Lei n. 11.977/2005 também proíbe que os espetáculos circenses pratiquem tal exploração: "Art. 21 - É vedada a apresentação ou utilização de animais em espetáculos circenses".

Outra prática esportiva danosa à integridade animal é o rodeio. Nesses eventos, um dos ritos preparatórios é a colocação do sedém na cintura do boi, uma espécie de cinta feita de lã ou algodão. Quando o boi está no brete - brete é um compartimento para reter bovinos, uma gaiola onde eles ficam antes do rodeio - o sedém é puxado, causando dor e desconforto ao animal, podendo provocar feridas na pele. Esse procedimento é feito para que o boi possa pular com o seu montador e a prática é danosa pois causa dor desnecessária ao animal. 
Neste sentido, segundo Martins (2009, p. 377):

A utilização de sedém, peiteiras, choques elétricos ou mecânicos e esporas gera estímulos que produzem dor física nos animais em intensidade correspondente à intensidade dos estímulos. Além da dor física, esses estímulos causam também sofrimento mental aos animais uma vez que eles têm capacidade neuropsíquica de avaliar que esses estímulos lhes são agressivos, ou seja, perigosos à sua integridade.

Em relação a prática com a utilização do sedém, a Lei n. 11.977/2005 tem expressa proibição:

Art. 22 - São vedadas provas de rodeio e espetáculos similares que envolvam o uso de instrumentos que visem induzir o animal à realização de atividade ou comportamento que não se produziria naturalmente sem o emprego de artifícios (SÃO PAULO, 2005).

Mesmo com a desfavorável vedação constitucional e jurisprudência do Supremo Tribunal Federal, ainda existem normas incompatíveis com o disposto no art. 225, inc. VII, da Constituição, dentro da própria Constituição. Exemplo de norma incompatível é a Emenda Constitucional n. 96, que entrou em vigor em 2017 e protege constitucionalmente a realizaçáo da vaquejada - prática na qual o vaqueiro, montado no cavalo, precisa segurar o boi pelo rabo a fim de derrubá-lo dentro de uma área delimitada e em um tempo específico - prática defendida pela Advocacia-Geral da União (AGU) e considerada constitucional por se tratar de tradição cultural.

A prática conhecida como "farra do boi", que acontece em Santa Catarina, consiste em soltar o animal em um local ermo e fazê-lo correr atrás dos participantes, deixando o boi exausto, para depois sacrificá-lo e dividir a carne entre os presentes. O evento é proibido por lei desde 1998. Ainda assim, a "farra do boi" ocorre da céu aberto, desrespeitando o direito desse animal e, de maneira ilegal, é considerada por parte da população do estado de Santa Catarina, como "cultura".

Talvez com o aumento de pena estabelecida pelo PLS n. 470/2018, que exclui o crime de maus-tratos contra os animais, do rol de crimes de menor potencial ofensivo, o infrator participante da "farra do boi" descontinue a sua participação. O estado de Santa Catarina deveria coibir tais eventos por meio da conscientização de seus habitantes, utilizando-se da contrapropaganda e inspirando-se no modelo adotado por São Paulo. 


\section{Direito Alienígena e o tratamento aos animais náo humanos}

$\mathrm{O}$ mundo não avançou muito com relação às práticas cruéis aos animais não humanos. Poucos países têm legislaçôes de proteção a sua integridade física, vida e dignidade. Os únicos países em que há um código exclusivamente para os animais são Alemanha, Áustria, Suíça, França e Portugal, todos pertencentes ao bloco econômico da Uniáo Europeia (UE), com exceção da Suíça.

Com relação à política com os animais não humanos, a principal preocupação da UE é o bem-estar, que pode se verificar em ao menos três diretivas: Diretiva n. 2010/63/EU (relativa ao tratamento de animais em experimentos científicos); Diretiva n. 76/768/CEE (relativa à aproximaçâo da legislação dos Estados-membros no que concerne a produtos cosméticos); Regulamento da CE n. 1.223/2009 (relativa aos produtos cosméticos).

Tratando-se de experiências científicas, a União Europeia reconhece os animais como vidas que podem sentir dor, angústia e sofrimento, tal qual um ser humano, na Diretiva n. 2010/63/EU:

Existem novos conhecimentos científicos a respeito dos factores que influenciam o bem-estar dos animais, assim como a capacidade dos mesmos para sentir e manifestar dor, sofrimento, angústia e dano duradouro. Por conseguinte, importa melhorar o bem-estar dos animais utilizados em procedimentos científicos, reforçando as normas mínimas relativas à sua protecçáo de acordo com a evoluçáo mais recente dos conhecimentos científicos (UNIĀO EUROPEIA, 2010, grifo nosso).

A Diretiva n. 2010/63/EU tem como finalidade reduzir e, futuramente, acabar com os experimentos em animais. Mas, enquanto não é possível acabar com esses procedimentos, há várias recomendaçóes aos países. Entre elas, está a de tentar promover o desenvolvimento de abordagens alternativas a esse tipo de exploração:

Embora seja desejável substituir a utilização de animais vivos em procedimentos por outros métodos que não impliquem a sua utilização, o recurso a animais vivos continua a ser necessário para proteger a saúde humana e animal, assim como o ambiente. Todavia, a presente directiva representa um passo importante para alcançar o objectivo final de substituir totalmente os procedimentos com animais vivos para fins científicos e 
educativos, tấo rapidamente quanto for possível fazê-lo do ponto de vista científico. Para o efeito, a presente directiva procura facilitar e promover o desenvolvimento de abordagens alternativas. Procura igualmente garantir um elevado nível de proteç̧áo dos animais que ainda seja necessário utilizar em procedimentos. A presente directiva deverá ser revista regularmente, tendo em conta a evolução científica e as medidas de protecção dos animais (UNIÃO EUROPEIA, 2010, grifo nosso).

Com relação a produtos cosméticos, a Diretiva n. 76/768/CEE foi modificada pelo atual Regulamento da CE n. 1.223/2009. A primeira diretiva não tinha preocupaçáo com o bem-estar dos animais no processo de teste dos produtos de maquiagem. Respeitando a Diretiva n. 86/609/CEE, que trata sobre aproximação das disposiçóes legislativas, regulamentares e administrativas dos Estados-membros respeitantes à proteçâo dos animais utilizados para fins experimentais e outros fins científicos. Esse regulamento dispõe de interessante artigo para reflexão:

Art. 41: É já possível assegurar a inocuidade dos produtos cosméticos acabados, com base nos conhecimentos relativos à segurança dos ingredientes que contêm. Por conseguinte, deverá prever-se um dispositivo destinado a proibir a realização de ensaios de produtos cosméticos acabados em animais. A aplicação, nomeadamente por pequenas e médias empresas, tanto de métodos de ensaio como de procedimentos de avaliaçáo dos dados relevantes disponíveis, incluindo a utilizaçáo de métodos por analogia e por valor de prova, que não impliquem o recurso à experimentação animal para a avaliação da segurança dos produtos cosméticos acabados, poderia ser facilitada mediante orientaçóes da Comissão.

Tal modelo de legislaçáo pode ajudar a revolucionar os processos de testes nas indústrias, servindo de exemplo para outros países cuja fauna é extremamente diversificada, como o Brasil.

Nos Estados Unidos, a Agência de Proteção Ambiental dos Estados Unidos (EPA) tem como missão proteger a saúde humana e meio ambiente.

A legislação ambiental americana é escassa; pouco se fala sobre a política de preservação animal. Dois exemplos são o lobo-cinzento e a onça-parda, encontrados em abundância na natureza, porém, extintos no Estados Unidos. Outros animais como o lobo-vermelho, endêmico da zona sudoeste dos Estados Unidos, sofrem no status de animais em perigo crítico de extinção.

Neste sentido, Regan (apud ZIMMERMANN, 2013, p. 94): 
[...] o fato de serem "sujeitos de uma vida" é a principal similitude entre o ser humano e os outros animais, característica que os faz ter um valor inerente, que é o direito de serem tratados com respeito e consideraçáo pela sua vida. Os sujeitos de uma vida, portanto, devem ser tratados como um fim em si mesmos, e náo como meio ou instrumento.

Regan (2013, p. 33) condena a utilização de animais como recursos, comida e a exploração deles por esportes ou dinheiro. Ele apresenta a visão dos direitos, reivindicando seu tratamento como sujeitos morais:

Mas todas as tentativas de limitar essa esfera somente aos humanos podem ser vistas como racionalmente defeituosas. Os animais, é verdade, carecem de muitas das habilidades que os humanos possuem. Eles não podem ler, fazer grandes contas, construir uma estante de livros ou fazer uma pasta de berinjela. Acontece que muitos seres humanos também não o podem, e nem por isso nós podemos (nem devemos) dizer que eles (esses seres humanos) possuem menos valor inerente, um direito menor de ser tratado com respeito do que os outros.

[...] literalmente, bilhôes e bilhôes - desses animais são sujeitos de uma vida, no sentido explicado, e então têm valor inerente como nós temos. E por isso, para chegar à melhor teoria de nossos deveres uns com os outros, nós devemos reconhecer como igual o nosso valor inerente como indivíduos, razão - não sentimento, nem emoção -, razão que nos compele a reconhecer igual valor inerente para esses animais e, como consequência, o igual direito deles de serem tratados com respeito.

Por ser uma potência, se países como os Estados Unidos adotassem políticas ambientais mais protetoras a sua fauna local, poderiam influenciar para que outros países tomassem atitude parecida.

Embora não seja expressivamente ativa com a preservação de outros animais não humanos, a China foi o principal país responsável pela retirada do panda-gigante da lista de espécies ameaçadas a extinção. Esse feito foi conquistado por meio do reflorestamento de bambu, principal alimento do mamífero omnívoro. Pandas-gigantes precisam comer, em média, 9 a 14 quilos de bambu para que seu corpo se mantenha em pleno funcionamento (GREEN, 2010).

Outro esforço feito pelo governo chinês foram as campanhas de conscientização para importância do antílope tibetano, também conhecido como "chiru". 
Eles são caçados por causa de seus chifres, muito valiosos no mercado do tráfico de animais.

\section{Consideraçóes finais}

A problemática que motivou essa pesquisa foi a de verificar de que maneira o Direito poderia contribuir para que os animais náo humanos possam ser respeitados em sua integralidade.

Os objetivos foram cumpridos, uma vez que foram apresentados posicionamentos doutrinários, legais e filosóficos que defendem o reconhecimento da vida com dignidade, aos animais. $\mathrm{O}$ resultado da pesquisa foi o de que os animais devem ser respeitados e ter a sua dignidade assegurada, não só para manter a própria vida, mas também para manter a qualidade de vida no planeta; pois o homem não vive só, uma vez que a existência de vida no planeta, depende de todas as espécies. Dessa forma, é necessário que, em virtude da existência do princípio da legalidade, sejam editadas normas de efetiva proteção aos direitos dos animais, tornando essas penas mais rígidas e com cunho educativo à quem utiliza os animais em suas atividades, tudo com base na Declaração dos Direitos dos Animais da Unesco, a fim de garantir-lhes o descanso, a alimentação adequada, a restrição a trabalhos forçados e a vivência digna em locais seguros. E a não violência ou práticas cruéis contra eles.

\section{Referências}

ANDRE, C.; VELASQUEZ, M. Of cures and creatures great and small. Santa Clara: Santa Clara University, 2015. Disponível em: <https:/www.scu.edu/ethics/ focus-areas/bioethics/resources/of-cures-and-creatures-great-and-small/>. Acesso em: 22 fev. 2019.

ARAÚJO, M.; MALUF, V. Desmascarei uma assassina: a história da gateira Juliana Bussab, que investigou a primeira serial killer de animais a ser presa no Brasil. Universa, 13 mar. 2018. Disponível em: <https://universa.uol.com.br/especiais/ desmascarei-uma-serial-killer-de-animais/index.htm>. Acesso em: 22 fev. 2019.

ARISTÓTELES. A política. 6. ed. São Paulo: Arena, 1999.

BARBOSA, V. Morte de cachorro em loja do Carrefour gera onda de protestos. Exame, 3 dez. 2018. Disponível em: <https://exame.abril.com.br/marketing/ morte-de-cachorro-a-pauladas-em-loja-do-carrefour-gera-onda-de-protestos/>. Acesso em: 29 jul. 2019. 
BÍBLIA ONLINE. Exodo. 23: 4-5. Disponível em: <https://www.bibliaonline. com.br/acf/ex/23>. Acesso em: 29 jul. 2019.

BÍBLIA ONLINE. Deuteronômio. 22: 1-4. Disponível em: <https://www.bibliaonline.com.br/acf/dt/22/1-4>. Acesso em: 6 set. 2019.

BONIFACIO, F. Tecnologia de pele 3D desenvolvida pelo grupo Boticário pode mudar a forma como cosméticos são testados no Brasil. Brazil Beauty News, 19 jul. 2016. Disponível em: <https://www.brazilbeautynews.com/tecnologia-de-pele-3d-desenvolvida-pelo-grupo,1414>. Acesso em: 22 fev. 2019.

BRASIL. Decreto n. 24.645, de 10 de julho de 1934. Estabelece medidas de proteção aos animais. Rio de Janeiro: Presidência da República, 1934.

BRASIL. Decreto-lei n. 2.848, de 7 de dezembro de 1940. Código Penal. Rio de Janeiro: Presidência da República, 1940.

BRASIL. Decreto-lei n. 3.688, de 3 de outubro de 1941. Lei das Contravençóes Penais. Rio de Janeiro: Presidência da República, 1941.

BRASIL. [Constituição (1988)]. Constituição da República Federativa do Brasil. Brasília, DF: Presidência da República, 1988.

BRASIL. Lei n. 9.099, de 26 de setembro de 1995. Dispóe sobre os Juizados Especiais Cíveis e Criminais e dá outras providências. Brasília, DF: Congresso Nacional, 1995.

BRASIL. Lei n. 9.605, de 12 de fevereiro de 1998. Dispóe sobre as sançóes penais e administrativas derivadas de condutas e atividades lesivas ao meio ambiente, e dá outras providências. Brasília, DF: Congresso Nacional, 1998a.

BRASIL. Instituto Brasileiro de Meio Ambiente. Portaria n. 93, de 7 de julho de 1998. Importação e Exportação de Fauna Silvestre Brasília, DF: Ibama, 1998b. Disponível em: <https://licenciamento.cetesb.sp.gov.br/legislacao/federal/portarias/1993_Port_IBAMA_95.pdf>. Acesso em: 6 set. 2019.

BRASIL. Ministério da Agricultura, Pecuária e Abastecimento. Instrução normativa n. 56, de 6 de novembro de 2008. Brasília, DF: Mapa, 2008. Disponível em: $<$ http://www.agricultura.gov.br/assuntos/sustentabilidade/bem-estar-animal/arquivos/arquivos-legislacao/in-56-de-2008.pdf>. Acesso em: 6 set. 2019.

CHUECCO, F. Prisão histórica: serial killer de animais foragida é finalmente presa. Agência de Notícias de Direitos Animais, 7 fev. 2018. Disponível em: <https:// www.anda.jor.br/2018/02/prisao-historica-serial-killer-de-animais-foragida-e-finalmente-presa/>. Acesso em: 29 jul. 2019. 
CÓDIGO DE HAMURABI. DHNET. Disponível em: <http://www.dhnet.org. br/direitos/anthist/hamurabi.htm>. Acesso em 29 ago. 2018.

CFMV - CONSELHO FEDERAL DE MEDICINA VETERINÁRIA. Resolução n. 877, de 15 de fevereiro de 2008. Dispóe sobre os procedimentos cirúrgicos em animais de produção e em animais silvestres; e cirurgias mutilantes em pequenos animais e dá outras providências. Brasília, DF: CFMV, 2008. Disponível em: <http://portal.cfmv.gov.br/lei/download-arquivo/id/1258>. Acesso em: 9 set. 2019 .

DESCARTES, Renée. O discurso do método. São Paulo: Escala, 2009.

DESCUBRA porque somos a empresa do ano no prêmio ABIHPEC Beleza Brasil. Grupo Boticário, 24 out. 2017. Disponível em: <http://www.grupoboticario. com.br/pt/acontece-por-aqui/Paginas/Descubra-porque-somos-a-Empresa-do-Ano-no-Pr\%C3\%AAmio-Abihpec-Beleza-Brasil.aspx>. Acesso em: 22 fev. 2019.

DIAS, E. C. A tutela jurídica dos animais. Belo Horizonte: Mandamentos, 2000.

FONSECA, A. Brasileira vira destaque internacional com projeto que substitui animais por pele 3D em testes com cosméticos. G1, 16 fev. 2018. Disponível em: <https://g1.globo.com/pr/parana/noticia/brasileira-vira-destaque-internacional-com-projeto-que-substitui-animais-por-pele-3d-em-testes-com-cosmeticos. ghtml>. Acesso em 22 fev. 2019.

GOMES, R. M.A.; CHALFUN, M. Direito dos animais - um novo e fundamental direito. In: XV CONGRESSO NACIONAL DO CONPEDI, 15., Manaus, 2006. Anais [...]. Florianópolis: Conpedi, 2006.

GREEN, A. L. (Ed.). Earth's changing environment. Chicago: Compton's by Britannica, 2010. (Learn \& Explore).

GRUPO BOTICÁRIO cria pele humana em 3d para testar cosméticos. IT Forum 365, 30 dez. 2017. Disponível em: <https:/www.itforum365.com.br/gestao/grupo-boticario-cria-pele-humana-em-3d-para-testar-cosmeticos/>. Acesso em: 22 fev. 2019.

KINSELLA, S. Legislação e direito em uma sociedade livre. Mises Brasil, 9 abr. 2013. Disponível em: <https://www.mises.org.br/Article.aspx?id=1570>. Acesso em: 11 jan. 2019.

MARTINS, R. F. Parecer: utilização de animais em rodeios. Revista Brasileira de Direito Animal, Salvador, ano 4, n. 5, p. 367-394, 2009. Disponível em: <https:// portalseer.ufba.br/index.php/RBDA/issue/view/903/showToc>. Acesso em: 11 jan. 2019. 
NICUIA, E. J. O papel do escravo em Aristóteles e Hegel. Dissertação (Mestrado) Programa de Pós-graduação de Filosofia, Pontifícia Universidade Católica do Rio Grande do Sul, Porto Alegre, 2009.

REGAN, T. A causa do direito dos animais. Revista Brasileira de Direito Animal, Salvador, v. 8, n. 12, p. 17-38, 2013. Disponível em: <https://portalseer.ufba.br/ index.php/RBDA/article/view/8385/6003>. Acesso em: 16 set. 2019.

RIBEIRO, M.V. História do direito. Jaguaré: Montecristo, 2012.

ROCHA, E. M. Animais, homens e sensaçôes segundo Descartes. Kriterion, Belo Horizonte, v. 45, n. 110, p. 350-364, dez. 2004. Disponível em: <http://www. scielo.br/scielo.php?script $=$ sci_arttext $\&$ pid $=$ S0100-512X2004000200008 > . Acesso em: 6 set. 2019.

RODRIGUES, D. T. O direito e os animais: uma abordagem ética, filosófica e normativa. 4. ed. Curitiba: Juruá, 2003.

SÃO PAULO (Estado). Assembleia Legislativa do Estado de São Paulo. Lei n. 11.977, de 25 de outubro de 2005. Institui o Código de Proteção aos Animais do Estado e dá outras providências. São Paulo: Alesp, 2005. Disponível em: <https:// www.al.sp.gov.br/repositorio/legislacao/lei/2005/lei-11977-25.08.2005.html>. Acesso em: 6 set. 2019.

SÃO PAULO (Estado). Assembleia Legislativa do Estado de São Paulo. Lei n. 16.308, de 13 de setembro de 2016. Dispóe sobre penalidades às pessoas que cometerem maus tratos a animais domésticos na forma que especifica. São Paulo: Alesp, 2016. Disponível em: <https:/www.al.sp.gov.br/repositorio/legislacao/lei/2016/ lei-16308-13.09.2016.html>. Acesso em: 6 set. 2019.

SENADO FEDERAL. Senado aprova aumento de pena para o crime de maus-tratos a animais. Senado Notícias, 11 dez. 2018. Disponível em: <https://www12. senado.leg.br/noticias/materias/2018/12/11/senado-aprova-aumento-de-pena-para-o-crime-de-maus-tratos-a-animais> Acesso em: 22 fev. 2019.

SINGER, P. Libertação animal. São Paulo: WMF Martins Fontes, 2010.

UNESCO. Declaração Universal dos Direitos dos Animais. Bruxelas, 27 jan. 1978. Disponível em: <http://www.urca.br/ceua/arquivos/Os\%20direitos\%20dos\%20 animais\%20UNESCO.pdf> Acesso em: 23 nov. 2018.

UNIĀO EUROPEIA. Directiva 86/609/CEE do Conselho de 24 de Novembro de 1986 relativa à aproximação das disposiçóes legislativas, regulamentares, e administrativas dos Estados-Membros respeitantes à protecção dos animais 
utilizados para fins experimentais e outros fins científicos. Disponível em: $<$ https:// publications.europa.eu/en/publication-detail/-/publication/cc3a8ccb-5a30-4b6e8da8-b13348caeb0c/language-pt >. Acesso em: 12 set. 2019.

UNIÃO EUROPEIA. Directiva 2010/63/UE do Parlamento Europeu e do Conselho de 22 de setembro de 2010 relativa à protecção dos animais utilizados para fins científicos. Disponível em: <https://eurlex.europa.eu/legalcontent/PT/TXT/ PDF/?uri=CELEX:32010L0063\&from=EN>. Acesso em: 12 set. 2019.

UNIÂO EUROPEIA. Directiva 76/768/CEE do Conselho, de 27 de julho de 1976, relativa à aproximação das legislaçóes dos Estados-Membros respeitantes aos produtos cosméticos. Disponível em: <https://publications.europa.eu/pt/publication-detail/-/publication/d9f2870a-bc01-423f-899c-f5fd5a2213ea>. Acesso em: 12 set. 2019.

UNIÃO EUROPEIA. Regulamento (CE) n. 1223/2009 Do Parlamento Europeu e do Conselho de 30 de novembro de 2009 relativo aos produtos cosméticos. Disponível em: https://eur-lex.europa.eu/LexUriServ/LexUriServ.do?uri=OJ:L:2009:342:0059:0209:pt:PDF>. Acesso em: 12 set 2019.

ZIMMERMANN, C. L. Um olhar sobre o direito dos animais. Revista Brasileira de Direito Animal. v. 8, n. 12, 2013. Disponível em: <https://portalseer.ufba.br/ index.php/RBDA/issue/view/772/showToc>. Acesso em: 12/09/2019. 


\title{
O PODER DE POLÍCIA DO CBMMG E O PARECER N. 15.719/2016 DA AGE: UMA ANÁLISE À LUZ DOS PRINCÍPIOS DA PREVENÇÁO E EFICIÊNCIA
}

\author{
Pedro Henrique Moreira da Silva ${ }^{1}$ \\ Escola Superior Dom Helder Câmara (ESDHC) \\ Pedro Henrique Cordeiro Gonçalves ${ }^{2}$ \\ Corpo de Bombeiros Militar de Minas Gerais (CBMMG) \\ Artigo recebido em: 10/07/2019 \\ Artigo aceito em: 23/09/2019
}

\section{Resumo}

A pesquisa pretende discutir a atuação do Corpo de Bombeiros Militar de Minas Gerais (CBMMG) na prevenção de incêndios e pânico. Recorrendo ao método hipotético-dedutivo, à análise da legislação e à pesquisa bibliográfica, objetiva-se apresentar os termos do parecer n. 15.719/2016 da AGE, que aponta a limitação do Poder de Polícia do CBMMG, com relação à possibilidade de interdição de estabelecimentos não regulares perante as normas técnicas tấo somente quando constatado o risco iminente. Não obstante, considerando-se a ausência de critérios objetivos para constatação da iminência de sinistros, questiona-se acerca da inviabilização da eficiência da atuação do CBMMG - o que se busca referendar pela invocação dos termos da Notícia de Fato MPMG n. 0024.18.021980-0. Nesse sentido, conclui-se que os limites para a interdição de edificações - além de onerar os servidores com a responsabilidade da discricionariedade - afetam a eficiência das normas técnicas de segurança, em desacordo com os fundamentos principiológicos do Direito Administrativo Ambiental - o que justifica a pesquisa.

Palavras-chave: Corpo de Bombeiros Militar; prevenção contra incêndio e pânico; princípio da eficiência; risco iminente.

1 Mestrando em Direito Ambiental e Desenvolvimento Sustentável pela ESDHC. Bacharel em Direito pela ESDHC. Professor no curso de Pós-Graduação em Direito Ambiental do Centro de Atualização em Direito (CAD). ORCID: http://orcid.org/0000-0002-8217-2169 / e-mail: pedroadvdireito@gmail.com

2 Cadete do CBMMG. Técnico em Edificações pelo Centro Federal de Educação Tecnológica de Minas Gerais (CEFET-MG). Bacharelando em Engenharia de Produção Civil pelo CEFET-MG. E-mail: goncalvespedro1997@gmail.com 


\section{THE POLICE POWER OF THE MILITARY FIRE BRIGADE OF MINAS GERAIS AND THE LEGAL OPINION N. 15.719/2016 OF THE GENERAL ADVOCACY OF THE STATE: AN ANALYSIS IN THE LIGHT OF THE PRINCIPLE OF PREVENTION AND EFFICIENCY}

\section{Abstract}

The research intends to discuss the performance of the Minas Gerais Military Fire Brigade $(C B M M G)$ in the prevention of fires and panic. Using the analysis of legislation and bibliographic research, the terms of opinion 15.719 / 2016, AGE and Decree 44.746, which limit the Police Power of the CBMMG regarding the possibilities of prohibiting non-regular establishments in relation to technical standards - with the possibility of interdiction only when the imminent risk is established. Nevertheless, considering the absence of objective criteria for finding imminent disasters, it is questioned about the ineffectiveness of the CBMMG's per- formance - which is sought by the invocation of the terms of the News of Fact MPMG n. 0024.18.021980 -0. In this sense, it is hypothesized that the limits to the prohibition - besides burdening the servers with the responsibility of discretion - affect the efficiency of technical safety standards, in disagreement with the fundamental principles of Environmental Administrative Law - which justifies the search.

Keywords: imminent risk; Military Fire Brigade; prevention of fire and panic; principle of efficiency.

\section{Introdução}

O Corpo de Bombeiros Militar de Minas Gerais (CBMMG), integrante do Sistema Nacional de Segurança Pública, atua como responsável - dentre outras competências - pela prevenção contra incêndio e pânico. Referida questão é regulamentada no Estado de Minas Gerais pela Lei n. 14.130/01 e pelo Decreto n. 44.746/08, além das Instruções Técnicas do próprio CBMMG.

Note-se que, para exercer referido papel, a Instituição goza de Poder de Polícia Administrativo, de forma que pode se utilizar da autoexecutoriedade, discricionariedade e coercibilidade para aprovar projetos e conceder o Auto de Vistoria do Corpo de Bombeiros (AVCB). Ainda, no caso de descumprimento das normas estipuladas, pode proceder a aplicação de multas e promover a interdição de estabelecimentos. 
Não obstante, pelo teor do Parecer n. 15.719/2016 da AGE, restou limitado o Poder de Polícia do CBMMG, na medida em que a interdição de edificações poderá ocorrer táo somente quando constatado o risco iminente - sob o entendimento de que as previsôes para interdição do Decreto Estadual n. 44.746/08 exorbitaram os poderes de regulamentação. Diante dessa constatação, a pesquisa recorre à análise da legislaçáo e da pesquisa bibliográfica para demonstrar que referida limitação implica entraves significativos no que tange ao serviço prestado pelos servidores públicos que integram o CBMMG.

$\mathrm{O}$ que se questiona, portanto, é se a possibilidade de interditar empreendimentos que não atendem às normas de prevenção de incêndio e pânico tão somente quando constatado o risco iminente náo terminaria por onerar os bombeiros encarregados, bem como se não resultaria na baixa eficiência das vistorias e das próprias normas de prevençáo. Isso porque, verificado o risco potencial pelo não cumprimento dos requisitos de segurança - mas ausente a iminência de sinistro - a atividade do CBMMG estará limitada à aplicaçáo de duas multas.

Acerca dessa realidade, a pesquisa objetiva invocar os termos da Notícia de Fato MPMG n. 0024.18.021980-0. No caso suscitado, demonstra-se que a fragilidade de instrumentos e alternativas de coerção disponibilizadas ao CBMMG acaba por direcionar a demanda ao Ministério Público do Estado que, diante de suas limitaçôes de competência, vê infrutífera a tentativa de resolução dos entraves - sendo compelido a encaminhar o imbróglio ao Judiciário, o que impacta na eficiência e celeridade da resolução de problemas que, não fosse a limitação do Poder de Polícia dos Bombeiros, poderia ser solucionado por vias extrajudiciais e autoexecutórias.

Nesse sentido, objetiva-se responder o questionamento supramencionado por meio da hipótese da necessidade de reformulação legislativa e interpretativa que considere os fundamentos principiológicos do Direito Administrativo Ambiental. Assim, dá-se ênfase aos princípios da prevenção e precaução como instrumentos para garantia da ordem urbanística - o que pode maximizar os resultados da atuação do Corpo de Bombeiros Militar de Minas Gerais e, consequentemente, impactar no bem-estar urbanístico que pretende promover a Instituiçáo por meio da prevenção de incêndios.

Para tanto, a pesquisa apresentará na primeira seção os panoramas sobre o trabalho e atuação do Corpo de Bombeiros Militar na prevenção contra incêndio e pânico, pontuando os principais desafios do empenho. Ademais, demonstrar-se-á os mecanismos de vistoria e sanção no caso de descumprimento das normas estaduais para garantia da segurança de edificaçóes. Na segunda seção, por sua vez, 
o estudo demonstrará as perspectivas e limitaçóes do poder de polícia da corporação, pontuando de que forma o Parecer n. 15.719/2016 da AGE termina por onerar a atividade do Corpo de Bombeiros de Minas Gerais, trazendo insegurança quanto a ordem urbanística e habitacional.

\section{Prevenção de incêndio e pânico}

O Corpo de Bombeiros Militar faz parte do Sistema Nacional de Segurança Pública, atuando como força militar auxiliar e reserva do Exército Brasileiro. Trata-se de instituiçáo de contornos estaduais, cuja consolidação ocorreu por força constitucional, notadamente pelo art. 144, $\$ \$ 5^{\circ}$ e $6^{\circ}$ da Carta Magna, que delega ao Corpo de Bombeiros Militar a responsabilidade pela Defesa Civil e Segurança Pública - ainda que nesta última seja suscitada controvérsia constante.

É o que se confirma, in verbis:

Art. 144.

$\$ 5^{\circ}$ Às polícias militares cabem a polícia ostensiva e a preservação da ordem pública; aos corpos de bombeiros militares, além das atribuiçóes definidas em lei, incumbe a execuçáo de atividades de defesa civil.

$\$ 6^{\circ}$ As polícias militares e corpos de bombeiros militares, forças auxiliares e reserva do Exército, subordinam-se, juntamente com as polícias civis, aos Governadores dos Estados, do Distrito Federal e dos Territórios (BRASIL, 1988, grifo nosso).

Referido dispositivo constitucional, por reafirmar a importância fundamental da Defesa Civil, desdobrou-se no Sistema Nacional de Defesa Civil, do mesmo ano da Constituição da República - cuja atualização ocorreu pela Lei n. 12.608, de 2012, com instituição da Política Nacional de Proteção e Defesa Civil, interligada ao Conselho Nacional de Proteção e Defesa Civil. Assim, restaram viabilizadas as centralizaçôes gerais da Defesa Civil, sobretudo no que tange a "prevenção, mitigação, preparação para emergência e desastres e recuperação de cenários atingidos por desastres" (CBMGO, 2018, p. 16).

Com relação ao Corpo de Bombeiros, diz-se, ainda, acerca das competências para salvamento, prestação de socorro, resgate e prevenção e combate a incêndios. Trata-se do dever preventivo e combativo para preservaçáo da ordem pública e bem-estar social - sobretudo nas perspectivas urbanísticas, em que a organização urbana por edificaçōes demanda uma tratativa técnica para evitar sinistros.

A partir dos panoramas jurídico-ambientais supramencionados, reforça-se a competência do Corpo de Bombeiros Militar na efetivação dos princípios da precaução e da prevençáo, principalmente por meio da promoção do equilíbrio 
da multidimensionalidade da sustentabilidade (em seus sentidos ecológicos e urbanísticos) - que coroa o ordenamento maior pela incorporaçáo da utopia de Estocolmo (1972) por parte do neoconstitucionalismo brasileiro. Nesse sentido, importa à pesquisa breve consideração acerca dos princípios supramencionados, para que sejam viabilizados os entendimentos relacionados às necessidades latentes de uma sociedade de risco (BECK, 2011).

No que tange ao Princípio da Precaução, trata-se de fonte do Direito para garantia de medidas que evitem os entraves ambientais de causa antropogênica - como forma de fazer desnecessária a própria mitigação ou compensação. Ora, trata-se de caminho para impedimento de danos irreversíveis, cuja confirmação científica é imprecisa (THOMÉ; DIZ, 2018, p. 42). Dessa maneira, ao Corpo de Bombeiros Militar incumbe recorrer às técnicas de formação de seus servidores para antecipação de riscos não contemplados pela doutrina e ciência.

O Supremo Tribunal Federal, seguindo referido entendimento, esclarece que a eficácia do Princípio da Precaução deve ser direta, como garantia do próprio Estado Democrático de Direito. Assim, há imperatividade na promoção do direito fundamental ao meio ambiente equilibrado, extrapolando-se aqui os limites de entendimento do meio ambiente natural, por meio de adoção de açôes proporcionais nos casos de incertezas (BRASIL, 2016).

Assim, as instituiçôes responsáveis pela Defesa Civil, segurança pública e demais açóes preventivas para garantia da ordem e do bem-estar devem adotar um comportamento tático como política de ação que baste para a leitura eficaz e eficiente de riscos e o impedimento antecipado de tragédias (GONÇALVES, 2013). Trata-se de dever do Estado na promoção dos direitos fundamentais de primeira, segunda e terceira geração, remontando a própria gênese das instituiçôes - que, em uma perspectiva ideal, surgem como forma de satisfazer os interesses e necessidades da sociedade (DALLARI, VENTURA, 2002).

Com relação ao Princípio da Prevenção, diz respeito à prevenção antecipada de fatos que, notadamente, afetarão a ordem do ambiente (SIRVINSKAS, 2011). Surge, portanto, para coroar as percepçóes de maior facilidade em se prevenir que em mitigar, tendo em vista o poupar-se os gastos e perdas de bens de valor econômico, histórico-cultural e afetivo. Nesse sentido, considerando a preocupação e delegação constitucional acerca da temática, ao Corpo de Bombeiros cabe o dever de atuação para evitar e combater referidos danos e ainda as mazelas eventuais (CIELO et al., 2012), seja por antecipaçáo de possibilidades, seja pela correçáo de constataçóes que indicam o possível risco.

O que se afirma, nesse sentido, é que o Corpo de Bombeiros é incumbido do dever de estabelecer condiçôes para evitar, mitigar e combater os riscos e suas 
possibilidades - competência que pode ser ampliada ou restringida a depender das legislações estaduais. Não obstante, é inegável que as capacidades técnicas da instituição são essenciais para a garantia da ordem ambiental e urbanística.

No Estado de Minas Gerais, por exemplo, as competências e atribuiçóes do Corpo de Bombeiros são esclarecidas e aclaradas pela Lei Complementar 54, de 13 de dezembro de 1999. Conforme se verifica, no art. $2^{\circ}$, caput, resta definida a instituição como "órgão com regime especial de administração centralizada, na forma de legislação estadual, e, como tal, integra-se ao sistema da administração do Estado" (MINAS GERAIS, 1999).

A seguir, o art. $3^{\circ}$ aponta as competências do CBMMG, quais sejam, in verbis:

I - coordenar e executar as açôes de defesa civil, proteção e socorrimento públicos, prevençáo e combate a incêndio, perícias de incêndio e explosão em locais de sinistro, busca e salvamento; II - atender à convocação, à mobilização do Governo Federal inclusive, em caso de guerra externa ou para prevenir grave perturbação da ordem ou ameaça de sua irrupção, subordinando-se à Força Terrestre para emprego em suas atribuiçôes específicas de Corpo de Bombeiros Militar e como participante da defesa interna e territorial;

III - coordenar a elaboraçáo de normas relativas à segurança das pessoas e dos seus bens contra incêndios e pânico e outras previstas em lei, no Estado;

IV - exercer a polícia judiciária militar, relativamente aos crimes militares praticados por seus integrantes ou contra a instituição Corpo de Bombeiros Militar, nos termos da legislaçấo federal específica;

$\mathrm{V}$ - incentivar a criação de Bombeiros não militares e estipular as normas básicas de funcionamento e de padrão operacional;

VI - exercer a supervisão das atividades dos órgãos e das entidades civis que atuam em sua área de competência;

VII - aprimorar os recursos humanos, melhorar os recursos materiais e buscar novas técnicas e táticas que propiciem segurança à população (MINAS GERAIS, 1999, grifos nossos).

Neste ponto, importará à pesquisa ater-se às questóes relativas às competências do Corpo de Bombeiros na prevenção de incêndios, sobretudo os urbanos. Isso porque, as hipóteses e conclusões finais serão tecidas a partir da análise da atuação da instituição nestes casos. 


\subsection{A prevenção de incêndio e pânico no Estado de Minas Gerais}

A prevenção contra incêndio e pânico no Estado de Minas Gerais é regulada pela Lei n. 14.130, de 2001, e alcança o controle das condiçóes de edificaçóes destinadas tanto ao uso coletivo - de fins comerciais ou industriais - quanto as edificaçôes residenciais, na forma do parágrafo único do art. $1^{\circ}$ da supracitada.

Nesse sentido, o art. $2^{\circ}$ da Lei 14.130/01 - seguindo as disposiçóes da Lei Complementar n. 54/99 - trata de delegar ao Corpo de Bombeiros Militar de Minas Gerais a competência para adoçáo de condutas passivas e ativas no que tange a prevenção, a partir da observância de parâmetros dentro das perspectivas dos princípios do Direito Administrativo Ambiental. É o que se verifica:

I - análise e aprovação do sistema de prevenção e combate a incêndio e pânico;

II - planejamento, coordenação e execuçấo das atividades de vistoria de prevençấo a incêndio e pânico nos locais de que trata esta lei;

III - estabelecimento de normas técnicas relativas à segurança das pessoas e seus bens contra incêndio ou qualquer tipo de catástrofe;

IV - aplicação de sanções administrativas nos casos previstos em lei (MINAS GERAIS, 2001).

O que se nota, portanto, é que o Corpo de Bombeiros Militar de Minas Gerais (CBMMG) deverá atuar - para além do combate efetivo às chamas [o que confere aos servidores o título de "heróis do fogo"] - na garantia de condiçóes urbanísticas que atestem a segurança contra incêndios. Nota-se que isso deverá ser realizado pela análise de projetos de prevenção de incêndio e pânico, realização de vistorias in loco, utilização de parâmetros técnicos para formulaçáo de normas específicas e, por último, pela aplicação de multas administrativas e/ou interdição - conforme se verificará a seguir.

Assim, as atividades da instituição estão alinhadas às disposições do Decreto n. 44.746, de 2008, que regulamenta a Lei n. 14.130/01. O que se busca, nesse sentido, é proporcionar a segurança da população, minimizar riscos para adjacências, meio ambiente e patrimônio, bem como garantir a intervenção e entrada do Corpo de Bombeiros nas edificaçóes - no caso de necessidade (MINAS GERAIS, 2008, art. $2^{\circ}$ ). 
Portanto, caberá ao Estado a capacitação dos Oficiais e Praças para exercício das funçôes, de forma que os referidos servidores sejam eficientes nas diligências para expedição ou cassação de Auto de Vistoria do Corpo de Bombeiros (AVCB), realização de pesquisas e perícias na área de prevenção [o que reforça a importância da Academia dentro da instituiçâo], planejamento de açôes táticas e estratégicas, fiscalização da legislação pertinente (MINAS GERAIS, 2008, art. 4º), bem como atuação como promotores da educação ambiental na sociedade.

Confirma-se o exposto, in verbis:

Art. $4^{\circ}-$ É de competência do CBMMG, por intermédio do Serviço de Segurança Contra Incêndio e Pânico:

I - capacitar seus oficias e praças por meio de cursos e treinamento, para desenvolvimento das atividades de verificaçáo da conformidade das medidas de segurança contra incêndio e pânico; II - analisar processos de segurança contra incêndio e pânico; III - realizar vistorias em edificaçóes e áreas de risco;

IV - expedir o respectivo AVCB;

$\mathrm{V}$ - cassar o AVCB ou o ato de aprovação do processo, no caso apuração de irregularidade;

VI - realizar estudos, pesquisas e perícias na área de segurança contra incêndio e pânico por intermédio de profissionais qualificados;

VII - planejar açôes e operaçôes na área da segurança contra incêndio e pânico;

VIII - fiscalizar o cumprimento deste Decreto e aplicar sançóes administrativas; e

IX - dispor sobre as medidas de segurança contra incêndio e pânico nas edificaçôes e áreas de risco e demais açōes previstas neste Decreto (MINAS GERAIS, 2008, art. 4º).

Nesse sentido, caberão as exigências de prevenção e combate a incêndio e pânico, a serem regulamentadas por Instruçóes Técnicas da Instituição, a saber:

a) IT05, que dispõe sobre a separação entre edifícios como condição de isolamento de risco;

b) IT08, que dispóe sobre a criação de saídas de emergência em edificaçóes;

c) IT11, que dispóe sobre plano de intervenção de incêndio;

d) IT13, que dispóe sobre a iluminação de emergência;

e) IT14, que dispóe sobre sistema de detecção e alarme de incêndio;

f) IT16, que dispóe sobre sistema de proteção por extintores de incêndio; 
g) IT17, que dispóe sobre sistema de hidrantes e mangotinhos para combate a incêndio;

h) IT21, que dispóe sobre sistema fixo de gases para combate a incêndio.

Assim, as edificaçóes construídas após a data da publicação do Decreto n. 44.746, de 29/02/2008, bem como as que se modificaram de forma a comprometer a eficiência das medidas de segurança, as que alteraram a ocupação ou uso ou ampliaram a área construída, deverão estar atentas às recomendações e imposições acerca dos procedimentos de segurança. Quanto as edificações construídas até o primeiro dia de julho de 2005, com Processo de Segurança Contra Incêndio e Pânico (PSCIP) aprovado, "deverão atender às tabelas específicas previstas em Instrução Técnica” (MINAS GERAIS, 2008, art. 5º).

Por fim, as demais edificaçôes terão seus requisitos determinados a depender do teor dos parágrafos $2^{\circ}$ ao 13 , do Decreto supracitado, conforme se transcreve:

$\$ 2^{\circ}$ - As edificaçóes projetadas ou em construção, cujo PSCIP tenha sido aprovado pelo CBMMG, até a data da publicação deste Decreto, terão garantidos os direitos de acordo com a legislaçẫo anterior, inclusive a emissão do AVCB.

$\$ 3^{\circ}$ - As edificaçóes existentes, cujos PSCIP foram aprovados e liberados pelo CBMMG, sofrerão vistorias permanentes, observada a legislação vigente à época de sua aprovação inicial. $\$ 4^{\circ}$ - Para as edificaçōes existentes, construídas até $1^{\circ}$ de julho de 2005, que não possuam Processo de Segurança Contra Incêndio e Pânico - PSCIP, aprovado e liberado pelo CBMMG, cuja área de ampliação especificada no inc. III ultrapassar cinquenta por cento da área comprovada da edificação, deverão atender às mesmas exigências previstas para edificaçôes construídas a partir da publicação deste Decreto.

$\$ 5^{\circ}$ - Para as edificações existentes, construídas até $1^{\circ}$ de julho de 2005, que possuam Processo de Segurança Contra Incêndio e Pânico - PSCIP, aprovado e liberado pelo CBMMG até a data da publicação deste Decreto, cuja área de ampliaçấo especificada no inc. III ultrapassar cinquenta por cento da área da edificação, deverão atender às mesmas exigências previstas para edificaçóes construídas a partir da vigência deste Decreto.

$\$ 6^{\circ}$ - Às ampliaçôes em edificações existentes, construídas até $1^{\circ}$ de julho de 2005 , que nấo ultrapassarem os limites previstos nos $\$ \$ 4^{\circ}$ e $5^{\circ}$, serão aplicadas tabelas específicas previstas no $\$ 1^{\circ}$, sendo aceitas quantas ampliaçóes necessárias, desde que observados os limites previstos. 
$\$ 7^{\circ}$ - Para as edificaçóes com projetos aprovados a partir de 2 de julho de 2005 até a data da publicação deste Decreto, serão aplicadas as exigências previstas na legislação em vigor da época. $\$ 8^{\circ}$ - Não se aplicam as exigências deste Decreto nos seguintes casos:

I - edificações residenciais unifamiliares, exceto àquelas que compóem um conjunto arquitetônico formado pelo menos por uma edificação tombada pelo patrimônio histórico e edificaçóes vizinhas, estas ainda que não tombadas, de tal modo que o efeito do incêndio gerado em uma delas possa atingir as outras; e II - residências unifamiliares de ocupação mista que tenham acessos independentes, podendo a edificação possuir no máximo dois pavimentos.

$\$ 9^{\circ}$ - As medidas de segurança contra incêndio e pânico em edificaçôes que compõem o patrimônio histórico deverão ser especificadas em Instrução Técnica.

$\$ 10$ - Nas edificações de ocupaçóes mistas serão observados os seguintes critérios:

I - não existindo compartimentação, deverão ser adotados os parâmetros correspondentes à ocupação que apresentar exigências mais rigorosas;

II - existindo compartimentação, deverão ser adotados os parâmetros correspondentes às exigências de cada uma das ocupações; III - nas situaçóes previstas nos incisos I e II, para fins de exigência de reserva técnica para a edificação, deverá ser observado o parâmetro mais rigoroso, considerando a área total da edificação. $\$ 11$ - Não é considerada ocupaçăo mista o conjunto de atividades onde predomina uma atividade principal que possua atividades secundárias fundamentais para a concretização da primeira.

$\$ 12$ - Para que a ocupação se caracterize como mista, é necessário que a área destinada às ocupaçôes principais diversas, excluindose a maior delas, seja superior a dez por cento da área total do pavimento onde se situa.

$\$ 13$ - As edificações e áreas de risco que não tenham sua ocupação ou seu uso definidos na Tabela 1 do Anexo deste Decreto deverão submeter-se às exigências definidas por Corpo Técnico (MINAS GERAIS, 2008).

Considerando-se o que se dispóe, importa frisar a necessidade de garantia de uma duração razoável para o processo administrativo que envolve a aprovação 
das condiçóes da edificação pelo Corpo de Bombeiros. Nesse sentido, o Decreto n. 44.746/08 trata de dispor acerca do protocolo de projeto com plantas e especificaçôes das medidas de segurança contra incêndio e pânico - a ser realizado por profissionais ou empresas cadastradas no Conselho Regional de Engenharia e Arquitetura (CREA).

A partir da apresentação do PSCIP, terá o CBMMG o prazo de quinze dias úteis para promover a respectiva análise por parte de Oficial ou Praça responsável que poderá deferir o teor do projeto apresentado, ou indeferir de forma motivada - com oportunizaçáo de correção dos pontos controversos, a serem novamente apreciados pelo CBMMG, no prazo de dez dias úteis. O que se nota, portanto, é que o deferimento do projeto não é uma atitude discricionária, mas vinculada ao atendimento de normas previamente estabelecidas pela legislação estadual.

Aprovado o PSCIP e executadas as medidas de segurança contra incêndio e pânico, promoverá o Corpo de Bombeiros a vistoria para emissão de Auto de Vistoria do Corpo de Bombeiros (AVCB), realizada no prazo de dez dias úteis a contar do protocolo de solicitação da vistoria. Estando em execuçáo as medidas de segurança delimitadas no projeto aprovado, proceder-se-á com a expedição do AVCB [com validade de três anos para locais de reuniáo de público e cinco anos para demais ocupaçóes].

\subsection{Sançóes administrativas}

No caso de constatada a inobservância das regras específicas no que tange à segurança contra incêndio e pânico, caberá ao Corpo de Bombeiros Militar de Minas Gerais a aplicação de sançôes administrativas, quais sejam, advertência escrita, aplicação de multa e, em último caso, a interdição da edificação (MINAS GERAIS, 2008, art. 11). Note-se que a advertência escrita é medida adotada na primeira vistoria, quando constatado o desrespeito a norma técnica regulamentar.

Após sessenta dias, caso não sanada a irregularidade que ensejou a notificação escrita, caberá a aplicação de multa "de 80,0645 a 2.404,9216 Unidades Fiscais do Estado de Minas Gerais - UFEMGs" (MINAS GERAIS, 2008). Ainda, se constatada a reincidência, promover-se-á a cassação do AVCB, o que se fará por processo administrativo próprio.

Com relação à aplicação de multa por reincidência, impera invocar o Parecer n. 16.011/2018 da Advocacia-Geral do Estado, no sentido de que o art. 4o $\$ \$ 3^{\circ}$, da Lei 14.130/2001 prescreve "nova multa", no singular - o que termina por limitar a atuação do CBMMG a apenas uma nova multa em dobro, de forma cumulativa. $\mathrm{O}$ ânimo do legislador ao restringir a aplicação de um número determinado 
de multas foi justamente de impedir o prolongamento da situação de risco. Assim, realizada nova diligência após a aplicação da primeira multa, poderá o Corpo de Bombeiros aplicar nova sanção pecuniária e, depois, ater-se aos procedimentos de cassação administrativa da documentação.

Permanecendo o estabelecimento com as irregularidades que ensejaram a aplicação de multas e cassação do AVCB, caberá a interdição - caso constatado o risco iminente. Assim, diz-se que é fragilizado o poder de polícia do CBMMG, vez que condicionado à constatação subjetivo de iminência de risco.

\section{$2 \mathrm{O}$ poder de polícia do Corpo de Bombeiros Militar}

A possibilidade de interdição de edificaçóes pelo Corpo de Bombeiros Militar de Minas Gerais decorre do Poder de Polícia administrativo que pode ser entendido como

[...] conjunto de atribuições da Administração Pública, indelegáveis aos particulares, tendentes ao controle dos direitos e liberdades das pessoas, naturais ou jurídicas, a ser inspirado nos ideais do bem comum, e incidentes não só sobre elas, como também em seus bens e atividades (LAZZARINI, 2008, p. 30).

Referendando os sentidos acima dispostos, Meirelles (2007, p. 138) trata de afirmar que o Poder de Polícia é "a faculdade de que dispóe a Administração Pública para condicionar e restringir o uso e gozo de bens, atividades e direitos individuais, em benefício da coletividade ou do próprio Estado”. Ainda, são atribuiçóes do Poder de Polícia a discricionariedade, autoexecutoriedade e a coercibilidade.

No que diz respeito à discricionariedade, relaciona-se ao poder da Administração em agir de acordo com as conveniências - desde que respeitados os elementos do art. 37, da Constituiçâo Federal, a saber, legalidade, impessoalidade, moralidade e eficiência. É o que se confirma:

Quando tem a lei diante de si, a Administração pode levar em consideração a área de atividade em que vai impor a restrição em favor do interesse público e, depois de escolhê-la, o conteúdo e a dimensão das limitaçóes. É o caso, por exemplo, em que autoridades públicas enumeram apenas alguns rios onde a pesca se tornará proibida. Sem dúvida que nesse momento a Administração age no exercício de seu poder discricionário (CARVALHO FILHO, 2011, p. 105). 
No que tange à autoexecutoriedade, diz respeito à possibilidade da Administraçáo Pública aplicar por ela mesma as sançóes necessárias para o alcance de seus objetivos finais. Isso, note-se, sem a necessidade de intervenção de outras searas da República - como o Poder Judiciário.

As medidas de polícia administrativa frequentemente são autoexecutórias, isto é, pode a Administração Pública promover, por si mesma, independentemente de remeter-se ao Poder Judiciário, a conformação do comportamento do particular às injunçóes dela emanadas, sem necessidade de um prévio juízo de cognição e ulterior juízo de execução processado perante as autoridades judiciárias. Assim, uma ordem para dissolução de comício ou passeata, quando estes sejam perturbadores da tranquilidade pública, será coativamente assegurada pelos órgãos administrativos. Estes se dispensam de obter uma declaraçâo preliminar do Judiciário, seja para declaração do caráter turbulento do comício ou da passeata, seja para determinar sua dissoluçáo (MELO, 2012, p. 857).

Por fim, quanto a coercibilidade, relaciona-se à possibilidade de utilização da "força”" para fazer cumprir a determinação da Administração, caso encontre resistência a sua satisfação. Note-se que, ao se referir a violência, diz-se acerca da força amparada nos limites da proporcionalidade e legalidade - necessária tâo somente para fazer acontecer o interesse do ente público. Referenda-se:

Diga-se, por oportuno, que é intrínseco a essa característica o poder que tem a Administração de usar a força, caso necessária para vencer eventual recalcitrância. É o que sucede, por exemplo, quando, em regime de greve, operários se apoderam manu militari da fábrica e se recusam a desocupá-la na forma da lei (CARVALHO FILHO, 2011, p. 107).

O que se diz, portanto, é que o Corpos de Bombeiros Militar - dotado de Poder de Polícia - pode valer-se de seus atos para a garantia de cumprimento dos sistemas técnicos para prevençáo e combate a incêndios. Assim, a aprovação ou náo de projeto contra incêndio e a própria aplicação de sanção pecuniária no caso de não observância das normas estaduais decorre de poder administrativo.

Note-se, ao aprovar ou não determinado projeto para edificação, os Oficiais e Praças do Corpo de Bombeiros exercem controle direto ao direito de propriedade que - apesar de aportar no ordenamento como direito fundamental - não é absoluto, e deve observar a função social do imóvel. Assim, dentro da competência que 
lhes cabe, seja na esfera de análise de questôes técnicas, seja na realização de vistorias in loco, a atividade do Corpo de Bombeiros é plena de polícia administrativa, sem prejuízos ao Estado Democrático de Direito, ao contrário.

Não obstante, importa dizer que o Poder de Polícia, apesar de garantir condutas discricionárias, não viabiliza uma postura arbitrária (CRETELLA JÚNIOR, 2012). Assim, importa que a legalidade do ato de polícia acompanhe as questóes da realidade, proporcionalidade e razoabilidade - que são limites técnicos à própria discricionariedade, sob pena de afronta à eficiência, impessoalidade e à própria moralidade [inscritas no caput do art. 37 da Carta Magna].

Nesse sentido, os Oficiais e Praças responsáveis pelas atividades de Prevenção e Combate a Incêndio e Pânico devem ter suas condutas pautadas nos termos da legislação estadual, mas sempre considerando os aspectos locais e reais do caso em testilha. Dessa forma, garante-se a pertinência de sua atuação - o que preserva a eficiência do serviço público que, mais que tornar a adequação às normas de segurança uma tarefa dispendiosa, garante a segurança efetiva da população.

\subsection{O Parecer n. 15.719/2016, da Advocacia-Geral do Estado de Minas Gerais}

Muito embora seja incontroverso o Poder de Polícia do Corpo de Bombeiros Militar de Minas Gerais, sobretudo no que diz respeito à possibilidade de aplicação de multas e até mesmo a interdição das edificaçóes, vale dizer que a atividade encontrou importantes limites após a emissão do Parecer n. 15.719/2016, da Advocacia-Geral do Estado de Minas Gerais. Isso porque, conforme a interpretação do Advogado-Geral do Estado, a autorizaçáo da Lei Estadual n. 14.130/01 não dizia respeito à obrigatória e imediata interdição dos estabelecimentos sem AVCB, conforme regulamentou o Decreto Estadual n. 44.746/08.

Ora, conforme supramencionado, a capacidade de aplicar sançóes é vinculada - em respeito ao princípio da tipicidade - de forma que só se aplicam sançôes que outrora e anteriormente estiveram prescritas em lei. Diz-se acerca da legalidade, de forma que só haverá conduta punível se existir lei anterior que a defina e determine a respectiva punição.

Nesse sentido, atendo-se aos sentidos do art. $4^{\circ}, \$ 4^{\circ}$, da Lei n. 14.130/2001, a Advocacia-Geral do Estado entendeu pela possibilidade de interdição de estabelecimentos táo somente quando constatado o risco iminente de incêndio e pânico - sob pena de violar os sentidos legais do ordenamento pátrio. Diz-se, portanto, que o Decreto Estadual n. 44.746/08 extrapolou os poderes regulamentares ao prever outras hipóteses para a interdição de edificaçóes. 
Dessa forma, a não observância das normas de prevenção de incêndio e pânico e a não realização de licenciamento para a emissão de licença por parte do CBMMG configura tão somente irregularidade administrativa não punível com a mais severa das sanções que pode ser aplicada pela Instituição - a interdição.

Isso pois, não atender aos requisitos previamente estipulados pela legislação e pelas instruçóes técnicas não configura - por si só - risco iminente. Da mesma forma, a ausência de Auto de Vistoria do Corpo de Bombeiros não é razão que motive a interdição do empreendimento, tendo em vista que pode a edificação ter atendido a todos os requisitos práticos sem êxito ou interesse nos requisitos burocráticos.

Nesse sentido, reduz-se a autoexecutoriedade e coercibilidade do Corpo de Bombeiros Militar de Minas Gerais e amplia-se a discricionariedade na medida em que o servidor designado às vistorias ficará incumbido de considerar condiçôes mínimas de segurança e condiçôes extremas de risco - conduta que encontra limites da perspectiva técnica, tendo em vista a inexistência de uma tabela que discrimine objetivamente as condiçôes de imóvel que configure risco iminente.

Acerca da conceituação do risco iminente, o art. $3^{\circ}$, inc. XXXVIII, do Decreto n. 44.746/2008 trata de definir tal risco, dispondo que se trata de uma exposição extrema e atual ao perigo, cuja probabilidade de causar danos à época da vistoria é também extrema. Diz-se acerca de perigo em potencial e atual, que ensejará a interdição imediata com vistas em garantir a segurança das pessoas que ali se encontram e frequentam.

A Instrução Técnica n. 02 do Corpo de Bombeiros Militar de Minas Gerais trata de referendar a questáo ao explanar que:

4.451 Risco iminente: É a constatação de situação atual e iminente de exposição ao perigo e a probabilidade de ocorrência de um sinistro que deve ser fundamentada pelo bombeiro militar durante a realizaçấo de vistoria levando-se em consideraçâo a exposição ao perigo potencial e as medidas de proteçăo adotadas no local (CBMMG, 2017, p. 35).

O entrave apontado, não obstante, reside justamente na dificuldade de constatação da iminência do risco e mais, na dificuldade da efetivação do trabalho do Corpo de Bombeiros Militar de Minas Gerais com vistas no alcance da eficiência da prevenção contra incêndio e pânico no caso da inviabilização de interdição dos estabelecimentos que não apresentem as condições necessárias para garantia da segurança. Isto é, ao delegar-se ao servidor o dever de constatar uma situação que não segue parâmetros objetivos, corre-se o risco de onerar o agente e seus superiores pela responsabilidade de garantir o bem-estar e a vida de outros a partir de condutas discricionárias e subjetivas. 
Nesse caso, importaria a construção de uma lógica legislativa que permitisse aos integrantes do Corpo de Bombeiros Militar de Minas Gerais a observância de modos práticos de declaração de iminência do risco. Isso, note-se, impactaria na própria segurança jurídica, uma vez que não estaria delegado o direito à vida e bem-estar a condutas discricionárias da Administração Pública.

No que tange à fragilização da eficiência do trabalho do CBMMG, diz respeito ao prolongamento das condiçóes de irregularidade - vez que a instituiçáo fica limitada à aplicação de uma segunda multa a partir do retorno da vistoria técnica. Com isso, ainda que o local represente risco potencial - mas sem a constatação da iminência de tragédias - poderá manter-se operante. Essa situação, note-se, vilipendia a própria razáo de ser do Poder de Polícia conferido ao Corpo de Bombeiros e a própria dinâmica do Direito Administrativo Ambiental, que se pauta nos princípios da prevenção e precaução, conforme supramencionado.

Dessa forma, constatado o desrespeito a critérios objetivos para prevençáo de incêndio e pânico, latente a necessidade de preservação da ordem urbanística e configuradas as incertezas acerca das possibilidades de incidentes, importaria a invocação da precaução - que implica interdição do estabelecimento pela dúvida motivada. Assim, o Parecer n. 15.719/2016 da AGE soa equivocado à pesquisa, na medida em que dispóe acerca da temática sem considerar a imperatividade principiológica que acompanha e fundamenta o Direito Ambiental como seara maior que abarca o Direito Urbanístico - contribuindo para a baixa eficiência dos serviços da Administração Pública.

É o que se confirma quando da invocação de caso noticiado na cidade de Belo Horizonte ainda no ano de 2019. Ora, conforme se extrai do teor da Notícia de Fato n. 0024.18.021980-0, de competência do Ministério Público de Minas Gerais, o estabelecimento denominado "Mercado Novo" encontra-se, até a data de abril de 2019, irregular perante as normas de segurança contra incêndio e pânico.

Apesar da não constatação da iminência do risco - embora notório e potencial - o Corpo de Bombeiros de Minas Gerais optou por noticiar a Promotoria competente, em razão de tratar-se de casa de espetáculos frequentada por quantidade considerável de pessoas e que possui histórico com incêndios. Ainda mais conturbado o relatório de fiscalizaçóes carreado pelo Corpo de Bombeiros nos autos do procedimento, que conta com a anotação de mais de 15 (quinze) vistorias no local - que ensejaram, vez ou outra, lavratura de Boletins de Ocorrência [quando da constatação de sinistros] e interdiçóes [quando da constatação de risco iminente].

Em que pesem o Auto de Notificação n. 20180009750AN, o Auto de Infração n. 20180009521AI, o Auto de Interdição n. 20180011997AT, o desinteresse 
do proprietário em promover a regularização do empreendimento fada o Corpo de Bombeiros Militar de Minas Gerais e o próprio Ministério Público do Estado ao limbo de ações. Isso porque seguem sendo realizadas diligências infrutíferas que - cedo ou tarde - implicarão no arquivamento do procedimento ou posterior distribuição da demanda para o Judiciário, por meio de Ação Civil Pública e/ou representação criminal.

A questáo é que, mobilizar o Poder Judiciário para referida demanda afeta o princípio da celeridade e da eficiência - argumento que bastaria em si mesmo para promoção de vias alternativas de resolução do conflito. Ademais, apesar de necessárias as limitaçôes práticas ao Poder de Polícia, o afastamento da atuação do Corpo de Bombeiros Militar não pode ensejar o desvio da demanda de trabalho da Administraçáo Pública para um dos Poderes da República, qual seja, o Judiciário, sob pena de afronta à descentralização prévia das atividades públicas.

O que se ressalta, portanto, é que uma revisão das condições supramencionadas se faz necessária como forma de garantir:

a) a eficiência do Poder de Polícia Administrativo do Corpo de Bombeiros Militar de Minas Gerais na efetivação e cobrança das regras de prevenção de incêndio e pânico, como forma de garantir a correta e ampla aplicação dos mandamentos legislativos acerca da questão;

b) parâmetros e critérios objetivos que possibilitem a verificação do risco iminente, como forma de superar a discricionariedade do ato - a fim de reduzir-se a responsabilidade dos servidores e reforçar os aspectos relacionados à segurança jurídica e ambiental urbanística.

\section{Consideraçóes finais}

Quando da atividade de prevenção de incêndio e pânico, o Corpo de Bombeiros de Minas Gerais (CBMMG) goza de Poder de Polícia Administrativa, podendo aprovar ou náo os projetos apresentados, bem como realizar vistorias e aplicar até duas multas pelo não atendimento dos requisitos da Lei n. 14.130/01, Decreto n. 44.746/08 e demais Instruçóes do próprio CBMMG. Não obstante, com relação à possibilidade de interdição de edificaçóes que não atendam às normas de prevenção contra incêndio e pânico, constatam-se restriçóes ao referido Poder Administrativo.

Isso porque, conforme se verifica do Parecer n. 15.716/16, da Advocacia-Geral do Estado, o Corpo de Bombeiros de Minas Gerais somente poderá aplicar a pena de interdição nos casos da constatação de risco iminente. Essa regulamentação e disposição - todavia - é problemática, na medida em que carente de critérios 
objetivos para configuração da iminência do risco, bem como por afetar a própria eficiência do trabalho de prevenção.

Nesse sentido, a pesquisa demonstrou que a limitação supramencionada termina por onerar os servidores do CBMMG, tendo em vista a responsabilidade subjetiva que advém com a discricionariedade na verificação do risco iminente. Da mesma forma, a impossibilidade de interdição dos empreendimentos quando não verificado o risco iminente fada o trabalho do Corpo de Bombeiros à ineficiência, na medida em que perpetuam-se as irregularidades sem a possibilidade de garantia efetiva da segurança das pessoas que se encontram ou frequentam o estabelecimento.

Ademais, a remessa das questóes de irregularidades não sanadas ao Ministério Público para ajuizamento de Ação Civil Pública também vilipendia os princípios da eficiência e celeridade processual, vez que se trata de demanda que poderia ser solucionada na própria esfera administrativa do Poder Executivo. Isto é, recorrendo à autoexecutoriedade e à coercibilidade, poderia o Corpo de Bombeiros Militar de Minas Gerais fazer cessar o risco potencial pela interdição das edificações - ainda que não iminente.

Assim, o estudo conclui pela necessidade de provocação do legislador e da própria Advocacia-Geral do Estado para consideraçáo dos fundamentos principiológicos que sustentam o Direito Administrativo Ambiental. Dessa forma, importa recorrer aos princípios da prevenção e precaução para garantia de melhor eficiência no trabalho do Corpo de Bombeiros Militar quando da atuação para prevenção de incêndios urbanos.

\section{Referências}

BECK, U. Sociedade de risco: rumo a uma outra modernidade. Rio de Janeiro: Editora 34. 2011.

BRASIL. Presidência da República. Casa Civil. Subchefia para Assuntos Jurídicos. Constituição da República Federativa do Brasil de 1988. Brasília, DF: Presidência da República, 1988. Disponível em: <http://www.planalto.gov.br/ccivil_03/constituicao/constituicao.htm>. Acesso em: 6 set. 2019.

BRASIL. Supremo Tribunal Federal. Recurso Extraordinário 627.189/SP. In: Súmulas. São Paulo: Associaçáo dos Advogados do Brasil, 2016.

CBMGO - CORPO DE BOMBEIROS MILITAR DO ESTADO DE GOIÁS. Manual operacional dos bombeiros: Defesa Civil, Goiânia: Secretaria de Segurança Pública. 2018. 
CBMMG - CORPO DE BOMBEIROS MILITAR DO ESTADO DE MINAS GERAIS. Instrução Técnica n. 02. Terminologia de proteção contra incêndio e pânico. 2017. Disponível em: <http://bombeiros.mg.gov.br/images/stories/dat/it/ it_02_2a_edicao.pdf >. Acesso em: 8 maio 2019.

CIELO, P. F. L. D. et al. Uma leitura dos princípios da prevenção e da precaução e seus reflexos no Direito Ambiental. Revista CEPPG, São Paulo, v. 26, n. 01, p. 196-207. 2002.

CRETELLA JÚNIOR, J. Polícia e poder de polícia. Revista de Direito Administrativo, Fundação Getulio Vargas, Rio de Janeiro, v. 162, p. 30-56. 1985.

CRETELla JúNIOR, J. Curso de Filosofia do Direito. 12. ed. Rio de Janeiro: Forense, 2012.

DALLARI, S. G.; VENTURA, D. F. L. O princípio da precaução: dever do Estado ou protecionismo disfarçado? São Paulo em Perspectiva, São Paulo, v. 16, n. 2, p. 53-63. 2002.

CARVALHO FILHO, J. S. Manual de Direito Administrativo. 24. ed. Rio de Janeiro: Lúmen Juris, 2011.

GONÇALVES, V. B. O princípio da precaução e a gestão dos riscos ambientais: Contribuiçôes e limitaçôes dos modelos econômicos. Ambiente e Sociedade, São Paulo, v. 16, n. 4, p. 121-140, out.-dez. 2013.

LAZZARINI, Á. Do Poder de Polícia. Revista de Jurisprudência do Tribunal de Justiça do Estado de São Paulo, São Paulo, v. 98. p. 40-69. 2008.

MEIRELLES, H. L. Direito Administrativo Brasileiro. 32. ed., São Paulo: Malheiros, 2007.

MELO, C. A. B. Curso de Direito Administrativo. 29. ed. São Paulo: Malheiros Editores, 2012.

MINAS GERAIS. Lei Complementar n. 54/99, de 13 de dezembro de 1999. Dispôe sobre a organização básica do Corpo de Bombeiros Militar de Minas Gerais - CBMMG - e dá outras providências. Disponível em: <http://leisestaduais.com. $\mathrm{br} / \mathrm{mg} /$ lei-complementar-n-54-1999-minas-gerais-dispoe-sobre-a-organizacao-basica-do-corpo-de-bombeiros-militar-de-minas-gerais-cbmmg-e-da-outras-providencias>. Acesso em: 23 set. 2019.

MINAS GERAIS. Lei n. 14.130, de 19 de dezembro de 2001. Dispóe sobre a prevenção contra incêndio e pânico no Estado e dá outras providências. Coleção de leis do Estado de Minas Gerais, Belo Horizonte, v. 79, n. 09, 2001. 
MINAS GERAIS. Decreto n. 44.746, de 29 de fevereiro de 2008. Regulamenta a Lei n. 14.130, de 19 de dezembro de 2001, que dispóe sobre a prevenção contra incêndio e pânico no Estado e dá outras providências. Coleção de leis do Estado de Minas Gerais, Belo Horizonte, v. 62, n. 03, 2008.

MINAS GERAIS. Decreto n. 46.595/2014. Altera o Decreto n. 44.746, de 29 de fevereiro de 2008, que regulamenta a Lei n. 14.130, de 19 de dezembro de 2001, que dispóe sobre a prevenção contra incêndio e pânico no Estado e dá outras providências. Coleção de leis do Estado de Minas Gerais, Belo Horizonte, v. 79, n. 09, 2014.

SIRVINSKAS, L. P. Manual de Direito Ambiental. 9. ed. São Paulo: Saraiva, 2011. THOMÉ, R. F. DIZ, J. B. M. Princípio da precaução: definição de balizas para a prudente aplicação. Veredas do Direito, Belo Horizonte, v. 15, n. 32, p. 36-66, maio-ago. 2018. 


\title{
A LEGALIDADE DAS ASSOCIAÇÓES DE PROTEÇÁO VEICULAR COMO ÓBICE AO REGIME FISCALIZATÓRIO PREVISTO NO DECRETO-LEI N. 73 DE 1966
}

\author{
Thiago Loures Machado Moura Monteiro ${ }^{1}$ \\ Escola Superior Dom Helder Câmara (ESDHC) \\ Henrique de Almeida Santos ${ }^{2}$ \\ Escola Superior Dom Helder Câmara (ESDHC) \\ Artigo recebido em: 05/08/2019. \\ Artigo aceito em: 12/09/2019.
}

\section{Resumo}

Este artigo tem por objetivo analisar a legalidade das Associaçôes de Proteção Veicular e a incompetência da SUSEP para fiscalização, tendo em vista as diferenças existentes entre contrato de seguro e proteção automotiva, e ainda a necessidade de criação de uma autarquia para fiscalização das associaçóes, tendo por base a legislação brasileira e decisão do STJ. Construída essa base, verificase que as associaçôes têm fundamento na Constituição Federal de 1988, no Código Civil de 2002 e no enunciado 185 da III Jornada de Direito Civil e que a criação de uma autarquia para fiscalização se dá em razão do interesse público e $\mathrm{da}$ incompetência $\mathrm{da}$
SUSEP para fiscalizar e regulamentar. O presente estudo foi desenvolvido com metodologia jurídico-teórica e raciocínio descritivo e explicativo, com técnicas de pesquisa bibliográfica, documental e estudo de caso. Concluiu-se que as associações são institutos jurídicos de direito privado, de acordo com o ordenamento jurídico brasileiro e que são indevidamente fiscalizados pela SUSEP, pelo que se faz necessária a criação de uma autarquia específica para fiscalização e regulamentação das associaçôes.

Palavras-chave: associação; legalidade; seguro; SUSEP; incompetência.

1 Mestre em Direito Ambiental e Desenvolvimento Sustentável pela ESDHC. Pós-graduado em Direito do Trabalho e Previdenciário pela Universidade FUMEC. Graduado em Direito pela Pontifícia Universidade Católica de Minas Gerais (PUC-MINAS). Professor na ESDHC. ORCID: https://orcid.org/0000-0001-6841-9930 / e-mail: thiagoloures.adv@gmail.

2 Graduando em Direito pela ESDHC. ORCID: https://orcid.org/0000-0001-8273-4523 / e-mail: henriquesantos@outlook.com 


\section{LEGALITY OF VEHICLE PROTECTION ASSOCIATIONS AS AN OBSTACLE TO THE INSPECTOR REGIME ESTABLISHED ON THE LAW DECREE N. 73 OF 1966}

\section{Abstract}

This article aims to analyse the legality of vehicular protection associations and SUSEP's incompetence to inspect them, seen the differences between insurance contract and automotive protection. It is needed to create an autarchy to inspect the associations, based on Brazilian legislation and STJ's decision. It is observed that those associations are substantiated by the 1988's Federal Constitution, by the 2002's Civil Code and by the 185th statement of the III Civil Law Journey. It is also worth noting that the creation of an audit autarchy is of public interest and SUSEP is incompetent to inspect and to regulate associations. This study was developed under legal-theoretical methodology and descriptive and explicative thinking, with bibliographic research and documental techniques and a case study. We conclude that the associations are private right legal instruments according to the Brazilian legal order and are unduly inspected by SUSEP, for which is needed to create a specific autarchy to audit and regulate them.

Keywords: Association; Legality; Insurance; SUSEP; Incompetence.

\section{Introdução}

As Associações de Proteção Veicular são institutos civis de direito privado, com registro no Cartório Civil de Pessoas Jurídicas, que têm como finalidade a ajuda mútua entre os associados para proteção de veículos. Pautam-se no rateio mensal dos prejuízos de todos os associados visando reduzir o valor mensal quando comparado ao seguro privado. Sua atuaçáo tem como fundamento o direito de livre associativismo presente no art. $5^{\circ}$ da Constituição Federal de 1988, bem como no enunciado 185 da III Jornada de Direito Civil.

Na última década, é notório o desenvolvimento dessa nova sistemática no cenário brasileiro visando dar segurança aos proprietários de veículos automotores que não possuem condições de arcar com o seguro automotivo ou eram excluídos do serviço em razão dos estudos atuariais praticados pelas seguradoras. Contudo, diante do manifesto avanço dos serviços associativos, sua legalidade foi questionada, gerando demandas judiciais fundamentadas na venda de seguros sem a devida autorização administrativa. 
Dessa maneira, diante do crescimento das associaçóes e, consequentemente, do número de associados, além da proximidade do serviço prestado pelas associaçóes e pelas seguradoras, houve um aumento em demandas judiciais propostas pela Superintendência de Seguros Privados (SUSEP) questionando a legalidade das instituiçóes privadas e a venda de "seguros piratas". Por outro lado, aqueles que defendem a proteçáo veicular, dizem que o serviço está de acordo com a legislação vigente e, diante da natureza jurídica do contrato associativo, defendem que a SUSEP não teria competência para fiscalização, bem como não seria órgão legítimo para propor demandas judiciais ou autorizar a criação das instituições.

Lado outro, em decisão recente (Recurso Especial n. 1.616.359-RJ), o Superior Tribunal de Justiça reconheceu a ilegalidade das associaçôes com fundamento na tipicidade do contrato. O Ministro OG Fernandes arguiu que o contrato se caracteriza de risco e não se enquadraria no quesito de ajuda mútua. Arguiu, ainda, que, no caso concreto julgado, a associação atuava de maneira indiscriminada, cobrando franquia e cobertura de danos provocados por terceiros e por eventos da natureza.

Não obstante, diante do crescimento do serviço de proteção automotiva e da falta de legislação específica para o serviço, dizem que é necessária a criação de um órgáo regulamentador específico para que os serviços atendam a funçáo social do contrato e não se submetam a fiscalização, indevida, da SUSEP. Nesse sentido, diante da discussão no âmbito cível-administrativo, indaga-se se contrato de proteção veicular confunde-se com o contrato de seguro devendo ser submetido ao regime de fiscalização da SUSEP.

Partiu-se da hipótese de que, diante do enunciado 185 da III Jornada de Direito Civil, combinado com os incs. XVII e XVIII do art. $5^{\circ}$ da Carta Constitucional de 1988, as associaçóes não se confundem com as seguradoras e, portanto, não estão submetidas à fiscalização da SUSEP, na forma do Decreto-Lei n. 73 de 1966. Ademais, em razão da citada distinção, a SUSEP seria incompetente para fiscalização e propositura de açóes judiciais em face das instituiçôes civis, com fundamento no Decreto-Lei n. 73 de 1966.

Todavia, com base na recente decisão do STJ e da incompetência da SUSEP, é necessária a criação de um ente regulamentador para fiscalização das associaçóes privadas. Não obstante, a necessidade de regulamentação será analisada com base na definição do poder de polícia e os princípios norteadores da administração pública.

Necessário demonstrar que o contrato de proteção veicular, além de estar de acordo com o ordenamento jurídico, distingue-se do contrato de seguro e 
que, dessa forma, a SUSEP, com base no Decreto-Lei n. 73 de 1966, não possui competência para fiscalizar e propor demandas em face das instituiçóes privadas, gerando a necessidade de criação de um órgão específico para fiscalização e regulamentação das Associaçôes de Proteção Veicular.

O presente estudo se justifica pela crescente utilização do serviço de proteção veicular e a falta de segurança jurídica causada pela fiscalização indiscriminada da SUSEP e com a ausência de legislação específica sobre o assunto. Em que pesem dispositivos normativos que indiquem a legalidade das associaçôes, ainda não há entendimento unânime sobre a questão, pois há ações civis questionando sua legalidade e a atuação.

Quanto à metodologia de pesquisa, esclarece-se que, quanto à abordagem do problema, a presente pesquisa classifica-se como qualitativa. Quanto ao método de abordagem, classifica-se como indutivo. Em relação aos objetivos, a presente pesquisa se caracteriza como descritiva e explicativa. No que tange às técnicas de coleta, será utilizada pesquisa documental, incluindo leis, acórdãos e pareceres, pesquisas bibliográficas em livros e artigos científicos. Por fim, realizar-se-á um estudo de caso analisando um acórdáo do STJ.

No decorrer do presente estudo serão apresentadas as definiçôes dos contratos de seguro, bem como o processo de constituição e formação das seguradoras, na forma do Decreto-Lei n. 73 de 1966, bem como a definiçãa do contrato de proteção veicular e o processo de formação e constituição das seguradoras na forma do Código Civil de 2002. Além disso, serão expostas as razóes que justificam a incompetência da SUSEP para fiscalização das associaçôes de proteção veicular, com fundamento no decreto que estabeleceu sua competência de atuaçáo e a necessidade de criação de um órgão regulamentador das Associaçôes de Proteção Veicular diante de sua atuação discriminada e a recente decisão do STJ.

\section{Aspectos jurídicos do contrato de seguro de automóveis 1.1 Definiçấo e constituição das seguradoras}

O contrato de seguro, em sentido amplo, está legalmente previsto no art. 757 do Código Civil de 2002, que diz: "Pelo contrato de seguro, o segurador se obriga, mediante o pagamento do prêmio, a garantir interesse legítimo do segurado, relativo a pessoa ou a coisa, contra riscos predeterminados" (BRASIL, 2002). Portanto, evidencia-se o surgimento de duas figuras: de um lado, o segurador que tem por obrigação garantir o legítimo interesse do segurado, de outro, o segurado, que apresenta como contraprestaçáo o pagamento do prêmio para que tenha seu interesse segurado. 
Além da definição legal, há a definição doutrinária. Do entendimento de Kriger Filho (2000, p. 18) extrai-se a seguinte definição:

[...] é desta noção sociológica que se pode tirar a ideia de seguro como o contrato pelo qual o segurador se obriga, perante o segurado, mediante o pagamento de certa quantia, a lhe garantir a indenizaçáo dos prejuízos resultantes dos riscos previstos, um negócio que em nosso país, no ano de 1997, somente em arrecadação de prêmios, movimentou mais de dezoito bilhôes de reais.

No caso do seguro de automóveis, o segurado, em regra, é o proprietário do veículo, e o segurador, uma seguradora devidamente constituída na forma da lei. ${ }^{3}$ Ademais, tratando-se do seguro de automóveis, o bem a ser segurado é, por consequência, o próprio automóvel. No entendimento de Silva (2012, p. 132), o contrato de seguro de automóveis tem por finalidade:

A transferência do risco existente na atividade econômica desenvolvida pelo segurado à sociedade especializada (seguradora), que se obriga, mediante certa contribuição em pecúnia avençada no contrato de seguro (prêmio), a garantir interesse legítimo segurável, relativo a bens ou pessoas contra riscos previstos no contrato.

Nesse diapasão, no seguro de automóveis propriamente dito, é necessário salientar que se trata de um negócio jurídico celebrado entre um particular e uma sociedade empresária destinada tão somente ao exercício da cobertura securitária mediante pagamento de um valor específico, denominado prêmio, que será avençado na celebração do contrato.

Portanto, em síntese, a partir dos conceitos legal e doutrinário, o contrato de seguro de automóveis pode ser definido como um contrato mediante o qual um particular, denominado segurado, na intenção de proteger seu veículo de eventuais riscos e avarias advindas da vida em sociedade, compromete-se a pagar uma quantia preestabelecida em contrato, denominada prêmio, para uma sociedade anônima, ou cooperativa, autorizada em lei, denominada seguradora, que garantirá o interesse do particular na proteção de seu veículo. Tratando-se, evidentemente, de uma relação bilateral.

Conforme anteriormente mencionado, as seguradoras para atuar no cenário brasileiro necessitam estar atentas ao disposto no Decreto-Lei n. 73 de 1966. Assim, devem, em primeiro lugar, estar constituídas na forma de sociedade

3 Art. 757, parágrafo único do Código Civil de 2002. 
anônima ${ }^{4}$ ou cooperativa ${ }^{5}$, de acordo com direito comercial societário brasileiro. Ademais, na forma do art. 36, a, do Decreto-Lei n. 73 de 1966, as sociedades constituídas devem submeter seu pedido de autorização à Superintendência de Seguros Privados, que deve processar os pedidos e remetê-los ao Conselho Nacional de Seguros Privados, tendo em vista a submissão ao poder público.

Sendo assim, cabe à SUSEP coordenar a maneira como as seguradoras seráo constituídas. A Circular SUSEP n. 529/16 dispóe a forma de constituição em seu art. $3^{\circ}$ :

Art. $3^{\circ}$ Os interessados na constituição, autorização para funcionamento, alteraçâo de controle societário, reorganizaçâo societária, redução do capital social e cancelamento da autorização para funcionamento de sociedades seguradoras, de capitalizaçáo, resseguradoras locais e entidades abertas de previdência complementar devem protocolar requerimento de autorizaçâo prévia na Superintendência de Seguros Privados - SUSEP, direcionado à coordenaçáo geral responsável por registros e autorizaçôes, identificando o responsável pela condução do projeto perante a SUSEP (SUSEP, 2016).

Outrossim, os anexos 1 ao 28 da referida circular dispóem sobre os documentos indispensáveis para a formação e autorização de atuação das seguradoras. Em síntese, verifica-se que a constituição das seguradoras está diretamente vinculada às instruçôes normativas internas da Superintendência de Seguros Privados.

\subsection{Superintendência de Seguros Privados 1.2.1 Definição e finalidade}

A Superintendência de Seguros Privados (SUSEP) é uma entidade autárquica, jurisdicionada ao Ministério da Indústria e do Comércio, dotada de personalidade jurídica de Direito Público, com autonomia administrativa e financeira ${ }^{6}$. É entidade integrante do Sistema Nacional de Seguros Privados, assim como o Conselho Nacional de Seguros Privados (CNSP); o Instituto de Resseguros do

4 A sociedade anônima é uma sociedade de capital. Os títulos representativos da participação societária (ação) são livremente negociáveis. Nenhum dos acionistas pode impedir, por conseguinte, o ingresso de quem quer que seja no quadro associativo. Por outro lado, será sempre possível a penhora da ação em execução promovida contra o acionista (COELHO, 2011, p. 211).

$5 \mathrm{~s}$ cooperativas, normalmente, dedicam-se às mesmas atividades dos empresários e costumam atender aos requisitos legais de caracterização destes (profissionalismo, atividade econômica organizada e produção ou circulação de bens ou serviços), mas, por expressa disposição do legislador, que data de 1971, não se submetem ao regime jurídico-empresarial. Quer dizer, não estão sujeitas à falência e não podem requerer a recuperação judicial. Sua disciplina legal específica encontra-se na Lei n. 5.764/71 e nos arts. 1.093 a 1.096 do CC, e seu estudo cabe ao Direito Civil (COELHO, 2011, p. 211).

6 Art. 35 do Decreto-Lei 73 de 1966. 
Brasil (IRB); os resseguradores; as sociedades autorizadas a operar em seguros privados e os corretores habilitados ${ }^{7}$.

Portanto, extrai-se que a SUSEP é uma autarquia Federal, dotada de personalidade jurídica de Direito Público, com competência fixada em lei e vinculada ao Sistema Nacional de Seguros Privados, jurisdicionada pelo Ministério da Indústria e do Comércio. Nesse sentido, a entidade é regida pelos princípios da Administração Pública, dentre eles o princípio da legalidade. $\mathrm{O}$ conceito jurídico do princípio da legalidade guarda-se na literalidade do art. 50, II, da $\mathrm{CF} / 88$, ao afirmar que: "ninguém será obrigado a fazer ou deixar de fazer alguma coisa senão em virtude de lei” (BRASIL, 1988).

Dessa forma, a SUSEP somente pode ter atuação nas atividades que lhe foram previamente instituídas pelo decreto. A finalidade da Superintendência de Seguros Privados, de acordo com seu site institucional é "desenvolver os mercados supervisionados, assegurando sua estabilidade e os direitos do consumidor". Para entender o termo "mercados supervisionados", é necessário analisar a competência atribuída à autarquia no decreto que a instituiu. A competência está prevista no art. 36 do Decreto-Lei n. 73 de 1966, que diz ser competência fiscalizatória da SUSEP:

a) processar os pedidos de autorizaçấo, para constituição, organização, funcionamento, fusão, encampação, grupamento, transferência de contrôle acionário e reforma dos Estatutos das Sociedades Seguradoras, opinar sôbre os mesmos e encaminhá-los ao CNSP;

b) baixar instruçóes e expedir circulares relativas à regulamentação das operaçóes de seguro, de acôrdo com as diretrizes do CNSP;

c) fixar condiçóes de apólices, planos de operaçôes e tarifas a serem utilizadas obrigatòriamente pelo mercado segurador nacional;

d) aprovar os limites de operaçóes das Sociedades Seguradoras, de conformidade com o critério fixado pelo CNSP;

e) examinar e aprovar as condições de coberturas especiais, bem como fixar as taxas aplicáveis;

f) autorizar a movimentação e liberação dos bens e valôres obrigatòriamente inscritos em garantia das reservas técnicas e do capital vinculado (BRASIL, 1966).

Cumpre registrar que as autorizações da atuação da SUSEP são restritas às atividades de Sociedades Seguradoras, incluindo ainda as seguintes competências: 7 Art. $8^{\circ}$ do Decreto-Lei 73 de 1966. 
$[\ldots]$

g) fiscalizar a execuçāo das normas gerais de contabilidade e estatística fixadas pelo CNSP para as Sociedades Seguradoras;

h) fiscalizar as operaçóes das Sociedades Seguradoras, inclusive o exato cumprimento dêste Decreto-Lei, de outras leis pertinentes, disposiçōes regulamentares em geral, resoluçōes do CNSP e aplicar as penalidades cabíveis;

i) proceder à liquidação das Sociedades Seguradoras que tiverem cassada a autorização para funcionar no País;

j) organizar seus serviços, elaborar e executar seu orçamento.

k) fiscalizar as operaçóes das entidades autorreguladoras do mercado de corretagem, inclusive o exato cumprimento deste Decreto-Lei, de outras leis pertinentes, de disposiçōes regulamentares em geral e de resoluçōes do Conselho Nacional de Seguros Privados (CNSP), e aplicar as penalidades cabíveis; e

1) celebrar convênios para a execução dos serviços de sua competência em qualquer parte do território nacional, observadas as normas da legislação em vigor (BRASIL, 1966).

Portanto, todas as atividades desenvolvidas na área de seguros, inclusive de automóveis, devem se submeter ao regime de constituição, fiscalização e organização desenvolvidos pela SUSEP. Dessa forma, por "mercados supervisionados", entende-se todos aqueles que envolvem as atividades securitárias e de resseguros, incluindo-se as atividades de cobertura voltadas ao mercado de automóveis.

Em síntese, compreende-se que a finalidade da SUSEP é fiscalizar, controlar e regulamentar todas as atividades econômicas voltadas às área de seguro, resseguro e atividades securitárias em geral com o objetivo de assegurar a estabilidade do mercado e os direitos, tanto do segurador quanto do segurado.

\section{A Associaçáo de Proteçáo Veicular como entidade civil 2.1 Definiçâo e constituiçáo da associaçáo}

As associações, em sentido amplo, são entidades civis com natureza jurídica de direito privado, registradas no cartório civil de pessoas jurídicas, com previsão na Carta Constitucional de 1988 e no Código Civil de 2002. Na Constituição, há previsão normativa no art. 5º XVII e XVIII, conforme texto a seguir:

Art. $5^{\circ}$ Todos são iguais perante a lei, sem distinção de qualquer natureza, garantindo-se aos brasileiros e aos estrangeiros residentes no País a inviolabilidade do direito à vida, à liberdade, 
à igualdade, à segurança e à propriedade, nos termos seguintes:

XVII - é plena a liberdade de associação para fins lícitos, vedada a de caráter paramilitar;

XVIII - a criação de associaçóes e, na forma da lei, a de cooperativas independem de autorização, sendo vedada a interferência estatal em seu funcionamento (BRASIL, 1988).

Da leitura dos dispositivos constitucionais verifica-se que a liberdade de associação é plena, excetuando-se a possibilidade de associar-se para fins paramilitares. Extrai-se, ainda, que para criação das associaçóes não se faz necessário requerimento de autorização, não havendo interferência estatal em seu funcionamento. Alexandre de Moraes assim define o direito constitucional:

É plena a liberdade de associação, de tal forma que ninguém poderá ser compelido a associar-se ou mesmo permanecer associado, desde que para fins lícitos, vedada a de caráter paramilitar, sendo que sua criação e, na forma da lei, a de cooperativas independem de autorização, vedada a interferência estatal em seu funcionamento, constituindo-se um direito que, embora atribuído a cada pessoa (titular), somente poderá ser exercido de forma coletiva, com várias pessoas (MORAES, 2017, p. 71).

No âmbito do direito civil, há a previsão da definição de associação no art. 53 do Código Civil de 2002, que dispóe: "Art. 53. Constituem-se as associações pela união de pessoas que se organizem para fins não econômicos" (BRASIL, 2002). Surgem, portanto, duas novas características das associaçóes: trata-se de uma união de pessoas, denominadas associadas, e não há interesse econômico na atividade das associaçôes.

Na doutrina, há a descrição das associações, conforme Bulos (2010, p. 588) diz: "Direito de associação é o direito público subjetivo que permite a coligação voluntária de algumas ou várias pessoas físicas, por longo tempo, com o propósito de alcançar objetivos lícitos, sob direção unificante”. Portanto, nesse sentido, o doutrinador entende que a associação é a união de pessoas, por um lapso temporal, com objetivos lícitos.

Ademais, tratando-se das associaçóes civis, conforme dispóe o art. 53 do $\mathrm{CC} / 02$, indispensável que sejam organizadas para fins não econômicos. Com relação à disposição normativa de fins não econômicos, assim entendem Farias e Rosenvald (2009, p. 331):

[...] é preciso, entrementes, uma interpretação cum grano salis da referida norma. Veja-se que as associaçōes podem (e, por que 
não dizer, devem) ter ganho financeiro. No entanto, o eventual lucro obtido no exercício da atividade associativa será reaplicado na própria entidade, vedando-se a partilha entre os sócios. Logo, a Lei não veda o lucro nas associaçóes, mas a sua divisão entre os associados. Equivale a dizer: o que não há nas associações é a persecução de lucro para a partilha entre os associados.

Portanto, a atividade associativa, em que pese não ter um fim econômico, pode vir a obter ganhos financeiros. Todavia, em caso de aferição de lucro, os associados não podem dividi-lo para fins de lucros pessoais do particular, é necessário que o valor obtido seja revertido em benefícios e em desenvolvimentos da própria instituição.

Além disso, evidenciam-se algumas características das associaçóes: trata-se de uma reunião de pessoas, um negócio jurídico plurilateral, em que vários particulares se associam a uma entidade civil devidamente registrada no cartório competente, que possui uma direção unificante. Não possui finalidade econômica, embora possa aferir lucro, sem, contudo, dividi-lo entre os associados. Pode ser instituída para qualquer finalidade, desde que lícita, vedando-se a de caráter paramilitar.

Tratando-se de entidade civil com natureza jurídica de direito privado, a forma de constituição das associaçóes está prevista no Código Civil de 2002, em especial no capítulo II, denominado "Das associaçôes", do título III denominado "Das pessoas jurídicas”. No art. 45 do CC/02, prevê-se o surgimento das associações:

Art. 45. Começa a existência legal das pessoas jurídicas de direito privado com a inscriçấo do ato constitutivo no respectivo registro, precedida, quando necessário, de autorizaçáa ou aprovaçáa do Poder Executivo, averbando-se no registro todas as alteraçôes por que passar o ato constitutivo (BRASIL, 2002).

Portanto, verifica-se que, o passo inicial para a existência de uma associaçáo é o registro de seus atos constitutivos no cartório de registro das pessoas jurídicas. Em regra, não se faz necessária autorização do poder executivo para a constituição das associaçôes, contudo, conforme dispóe o artigo, quando se fizer necessária a autorização do poder executivo, o registro das associaçóes fica condicionado a respectiva autorização ou aprovação.

Dispóe ainda o Código Civil que a relação entre a associação e seus associados será regida de acordo com o estatuto, não havendo entre os associados direitos e obrigaçóes recíprocos ${ }^{8}$. $\mathrm{O}$ art. 54 dispóe de assuntos obrigatórios que deverão constar do estatuto:

8 Art. 53, Parágrafo único do Código Civil de 2002. 
Art. 54 Sob pena de nulidade, o estatuto das associaçôes conterá: I - a denominação, os fins e a sede da associação;

II - os requisitos para a admissão, demissão e exclusão dos associados;

III - os direitos e deveres dos associados;

IV - as fontes de recursos para sua manutenção;

$\mathrm{V}$ - o modo de constituição e de funcionamento dos órgãos deliberativos;

VI - as condiçốes para a alteração das disposiçōes estatutárias e para a dissolução.

VII - a forma de gestấo administrativa e de aprovaçấo das respectivas contas (BRASIL, 2002).

Não havendo, pois, algum dos requisitos elencados no artigo, o estatuto poderá ser declarado nulo. Além disso, o Código prevê que entre os associados deverá haver igualdade de direito, em que pese tenha sido dada a possibilidade de o estatuto prever categorias com vantagens especiais?

Constata-se que para a constituição de uma associação, é necessário, primeiramente, realizar a inscriçấo de seus atos constitutivos no Cartório de Registro Civil das Pessoas Jurídicas. Além dos atos constitutivos, ainda é necessária a redação de seu estatuto, que conterá as informaçóes básicas da associação, como sua sede, finalidade, os requisitos para admissão, demissão e exclusão dos associados, as fontes de recursos e, ainda, o funcionamento de seus órgãos deliberativos. Maria Helena Diniz assim define os atos constitutivos e o estatuto:

O ato constitutivo da associação consiste num conjunto de cláusulas contratuais vinculantes, ligando seus fundadores e os novos associados que, ao nela ingressarem, deveráo submeter-se aos seus comandos. Nele deverão estar consignados sob pena de nulidade: a) a denominação, os fins e a sede da associação; b) os requisitos exigidos para admissão, demissão e exclusão dos associados; c) os direitos e deveres dos membros componentes; d) as fontes de recursos financeiros para sua manutençâo para evitar "lavagem" de dinheiro (Lei n. 9.613/98) e delitos disfarçados por atos beneficentes; e) o modo de constituiçáo e de funcionamento dos órgãos deliberativos; $\mathrm{f}$ ) as condiçôes para a alteraçấo do estatuto $\mathrm{e}$ para a dissoluçáo da entidade, dispondo sobre o destino do patrimônio social; g) a forma de gestão administrativa e de aprovação das respectivas contas. Logo, deverá ser constituída, por escrito, mediante redação de um estatuto, lançado no registro geral (CC,

9 Art. 55 do Código Civil de 2002. 
arts. 54, I a VII, e 45), contendo declaração unânime da vontade dos associados de se congregarem para formar uma coletividade, não podendo adotar qualquer das formas empresárias, visto que lhe falta o intuito especulativo (DINIZ, 2012, p. 276).

Evidente, pois, que o estatuto é indispensável para o funcionamento da associação. Ademais, exceto quando expressamente previsto em lei, as associações não dependem de qualquer autorização executiva e não se submetem a qualquer tipo de fiscalização do poder público. Surge, portanto, uma nova característica das associaçôes, são regidas por suas disposiçôes estatutárias.

\subsection{Associaçáo de Proteção Veicular 2.2.1 Definiçáo}

As associações surgem da necessidade da população civil, que não era contemplada pelo serviço de seguros, em proteger seus veículos diante do alto índice de violência e insegurança pública. Diante disso, surgiu a ideia de, por meio do associativismo, ou seja, de uma reuniáo de pessoas, para dividir o valor gasto com os danos patrimoniais decorrentes dos sinistros automotivos, diminuindo o valor gasto para manutenção das avarias e garantido aos associados o direito de socorro mútuo.

No entendimento de Britto (2016, p. 3-4), assim se definem as Associaçóes de Proteção Veicular:

[...] associaçôes de proteção veicular, assim comumente referidas para dar conta das pessoas jurídicas de direito privado: a) que tenham por objeto social a tutela financeiro-coletiva de veículos dos respectivos associados; b) desprovidas de qualquer finalidade lucrativa por parte delas próprias, associaçóes civis particulares. Mais precisamente, trata-se de entidades associativas privadas que se constituem com o fito de assumir, assim por modo coletivo, as consequências financeiras de eventuais furtos, roubos, incêndios ou entấo colisão de veículos automotores de propriedade particular. Eventos lesivos, portanto, da propriedade veicular que os respectivos associados detenham a título jurídico privado.

Portanto, verifica-se que as Associaçôes de Proteção Veicular têm como objeto a proteção financeiro-coletiva de veículos dos associados e não possuem finalidade lucrativa. Contudo, quanto à finalidade lucrativa, há divergência doutrinária, uma vez que, no pensamento de Farias e Rosenvald (2009), as associaçóes, 
independentemente de sua finalidade, podem visar a lucro, sem, contudo, reparti-lo entre os associados, devendo ser este investido na própria associaçáo.

Corrobora com o pensamento de Britto o exposto por Silva e Reche (2014, p. 44), que definem como um meio de inclusão social:

Desta forma, como um meio de inclusão social, tem-se que as associaçōes de proteção veicular, formadas por um grupo de pessoas (associados), com o mesmo intuito, qual seja, proteger seus veículos de fatores externos, que estejam fora do controle das suas vontades, promovem esta assistência por meio de contribuiçôes e rateios mensais feitos pelos associados, dividindo os prejuízos destes.

Portanto, das definiçôes apresentadas, é possível extrair conceitos em comum. As Associaçôes de Proteção Veicular têm por finalidade a proteção do bem de seus associados, no caso, veículos, as contribuiçôes se dão por rateio mensal de todos os prejuízos de todos os associados. Todavia, em que pese o conceito doutrinário, ainda se discute quanto à legalidade das Associações de Proteção Veicular.

\subsubsection{Legalidade das Associaçóes de Proteção Veicular}

No universo jurídico, muito se discute sobre a legalidade das Associações de Proteção Veicular. A Superintendência de Seguros Privados, por meio de seu site institucional, classifica as proteçôes automotivas como "seguro pirata", comercializado ilegalmente e sem a autorização da autarquia.

Todavia, aqueles que sustentam a legalidade das Associaçóes de Proteçáo Veicular, baseiam-se principalmente no art. 5º, XVII e XVIII, da Constituição Federal. Além disso, alguns doutrinadores se apoiam no enunciado 185, objeto de discussão da III Jornada de Direito Civil, que estipulou:

185 - Art. 757: a disciplina dos seguros do Código Civil e as normas da previdência privada que impôem a contrataçâo exclusivamente por meio de entidades legalmente autorizadas não impedem a formação de grupos restritos de ajuda mútua, caracterizados pela autogestẫo (BRASIL, 2002).

A respeito do enunciado, tece-se o respectivo comentário:

Percebe-se que o enunciado 185 autoriza grupos de ajuda restritos a prestaçấo de serviços sob a forma de autogestão, permitindo desta forma a uniáo de determinado segmento, como os caminhoneiros, a se unirem e ratearem todos os eventos acontecidos, 
estes que, não foram aceitos pelas seguradoras (SILVA; RECHE, 2014, p. 46).

Portanto, com fundamento no enunciado, verifica-se que a associações são grupos de ajuda mútua com associados restritos que se utilizam da autogestão para suprimir a ausência de cobertura securitária para proteçáo de seus bens. Corrobora com o enunciado o disposto por Diniz (2012, p. 276, grifos da autora):

A associação (Verein) é um contrato pelo qual certo número de pessoas, ao se congregar, coloca, em comum, serviços, atividades, conhecimentos, em prol de um mesmo ideal, objetivando a consecução de determinado fim não econômico (Idealvereiri) ou econômico (wirtschaftliche Verein), com ou sem capital, e sem intuitos lucrativos (CC, art. 53). Poderá ter finalidade: a) altruistica (associação beneficente); b) egoística (associação literária, esportiva ou recreativa); e c) econômica não lucrativa (associaçáo de socorro mútuo).

Nesse sentido, tanto no entendimento do enunciado 185 quanto da autora Maria Helena Diniz, as associaçôes estão de acordo com o sistema jurídico brasileiro desde que se trate de um grupo restrito de ajuda, ou socorro mútuo, e não possuam finalidade lucrativa. Todavia, vale ressaltar que se tratando de finalidade econômica não lucrativa, não se impede que as associaçôes tenham lucro, vedada tão somente sua repartição entre os associados do grupo.

Quando indagado sobre a licitude das Associações de Proteção Veicular, assim se manifesta Britto:

Sim! Considerando que tal objeto associativo não se enquadra no conceito legal de seguro, não há, no Ordenamento Jurídico brasileiro, qualquer óbice à organização associativa de proteção veicular privada. Incidindo diretamente ao caso a plena e constitucional liberdade de associação que vem altissonantemente estampada no inc. XVII do art. $5^{\circ}$ da Constituiçăo (BRITTO, 2016).

Pelo exposto, evidencia-se que a legalidade da proteçáo automotiva não é unânime no mundo jurídico. Por um lado, a autarquia responsável pela fiscalização das seguradoras entende que se trata de venda de seguros sem a devida autorização. Por outro lado, o direito de associação é um direito constitucional, e, diante das diferenças existentes entre o contrato de seguro e o de proteçáo automotiva não se trata de venda de seguro, mas de rateio entre associados que se reuniram para proteção de seus veículos. 
O direito de livre associação é fundamental, vedando-se apenas a associação de pessoas para fins paramilitares. Não obstante, sendo distinto o contrato de seguro e o de proteção automotiva, não há qualquer vedação à formação das associaçôes. Dessa forma, forçoso se concluir que as associaçóes são legítimos institutos civis de direito privado.

Além disso, a fim de consolidar o entendimento acerca da legalidade das Associaçôes de Proteção Veicular, está em pauta no Congresso Nacional o Projeto de Lei do Senado n. 356 de 2012, de autoria do Senador Paulo Paim, com a finalidade de acrescentar no art. 53 do Código Civil a previsão de os transportadores de pessoas ou cargas organizarem-se em associaçáo de direitos e obrigaçóes recíprocas para criar fundo próprio, desde que seus recursos sejam destinados exclusivamente à prevençáo e à reparação de danos ocasionados a seus veículos por furto, acidente, incêndio, entre outros. Todavia, o projeto ainda não foi submetido a votação pelo Congresso.

\section{Diferenças entre o contrato de seguro e proteçáo automotiva}

As Associaçóes de Proteção Veicular decorrem de uma lacuna no mercado em razão da falta de cobertura securitária pelas tradicionais seguradoras que não vendem apólices a determinados grupos em razão de estudos atuariais ou vendem apólices com preços altos.

Nesse sentido, diversas são as diferenças aptas a justificar a ausência de identidade entre o contrato de seguro e o contrato de proteçáo automotiva. Em primeiro lugar, nota-se a distinção dos serviços em razão do sujeito que presta os serviços: as seguradoras, obrigatoriamente, devem ser sociedades anônimas ou cooperativas devidamente autorizadas a prestar o serviço pela Superintendência de Seguros Privados. Por outro lado, as Associaçóes de Proteção Veicular devem ser constituídas na forma de associação devidamente registrada no cartório civil de registro das pessoas jurídicas.

Em decorrência do sujeito prestador dos serviços, surge uma nova diferença entre os contratos, o número de sujeitos que integram o negócio jurídico: no caso do contrato de seguro, trata-se de uma relação bilateral entre o segurado, interessado em segurar seu veículo mediante o pagamento de determinada quantia (prêmio) previamente estabelecida em contrato/apólice e a seguradora, interessada no lucro mediante a assunçáo do risco do veículo segurado. No caso das Associaçốes de Proteçâo Veicular, há uma relação plurilateral entre todo o grupo de pessoas que se reuniu para proteção de seus bens, ora veículos, mediante 
a repartição dos prejuízos de todo o grupo em determinado período, seja mensal, semestral, anual etc. A respeito do contrato de seguro, assim se manifestou Britto:

Do ponto de vista normativo ou da estrutura identitário-jurídica das coisas, o contrato de seguro veicula típica relação de troca. Uma relação em que a oferta da garantia implica a assunção do risco. Um elemento contramal a puxar o outro (sempre no pressuposto do pagamento do prêmio), mas sem que ambos figurem na mesma esfera jurídico-patrimonial. Pelo contrário: é pela outorga (remunerada) da garantia ao segurado que a seguradora passa a incorporar o risco ou dano potencial que pairava sobre o patrimônio jurídico do cocontratante. Dando-se, portanto, um verdadeiro câmbio de posiçōes jurídicas entre os contraentes, a revelar núcleos patrimoniais estanques ou distintos (BRITTO, 2016).

Contrapondo com o contrato de seguro, o autor assim se manifesta sobre o contrato de proteçáo automotiva:

Já nas associaçóes de proteção veicular, o caso é de uma pluralidade de relaçóes jurídicas, todas elas enfeixadas na pessoa jurídico-associativa. Com o que se trata, na essência, de um complexo vínculo de mutualismo jurídico, pelo qual os associados conjugam esforços financeiros (via mensalidades ou rateios ex posf) em torno da garantia dos interesses de todos. E por essa precisa ou exata razão comungam, todos eles, dos riscos sobre cada qual dos patrimônios garantidos. Numa frase, não há propriamente um liame contratual sinalagmático. O que se tem nas associaçôes de proteçẫo veicular são vínculos de sobreposição jurídica, a ter como ponto de unidade a figura da associaçấo e por base normativa não um instrumento contratual, mas uma ordenação estatutária. Denotando-se, com isso, o entrelaçamento patrimonial entre todos aqueles que, voluntária e vaüdamente, venham a aderir aos quadros associativos privados (BRITTO, 2016).

Do discorrido pelo autor, extrai-se uma nova diferença entre os contratos, enquanto as seguradoras estáo subordinadas às disposiçóes normativas do Sistema Nacional de Seguros Privados, as Associaçóes de Proteção Veicular se subordinam ao próprio estatuto, exercício de autogestão. Ademais, outra distinção entre as associaçôes e as seguradoras está no modo de contratação dos serviços: nestas, a contratação se dá mediante assinatura de uma apólice constando as cláusulas gerais 
dos serviços prestados. Naquelas, o associado assina um termo de responsabilidade mútua se submetendo ao estatuto.

Silva e Reche (2014), ainda a respeito das distinçôes, introduzem o pensamento a respeito do modo de utilizaçấo da verba paga pelo associado, no caso da proteçáo automotiva, ou do segurado, no caso do contrato de seguro. Assim se manifestam:

Outro exemplo da distorção das alegaçóes das Seguradoras são as famigeradas reservas, essenciais no seguro para a garantia dos segurados que pagam o prêmio antecipadamente para, depois, se ocorrido o sinistro, pagar a indenização. Cumpre notar que a medida que desaparece o risco - venceu o prazo do seguro - a reserva é liberada, podendo ser livremente utilizada no negócio. Na proteção automotiva, a apuração do prejuízo precede ao pagamento do rateio e, feito este, os valores são divididos e quando arrecadados, são imediatamente utilizados na liquidação dos prejuízos, de tal forma que, ao se falar em reservas, elas seriam constituídas, no momento exato de sua liberaçáo, o que seria, sem dúvida, um contrassenso (SILVA; RECHE, 2014, p. 45).

Sendo assim, no entendimento dos autores, enquanto as seguradoras condicionam a indenizaçáo pelo sinistro ocorrido ao pagamento prévio do prêmio estipulado em contrato, ou seja, formam uma reserva como espécie de garantia, as associaçóes repartem os prejuízos e no momento em que o associado paga sua quota, a verba é destinada à liquidação dos prejuízos de todos os associados.

Portanto, diante das diferenças entre os dois contratos, de proteção automotiva e de seguro automotivo, é notório que não há identidade entre os serviços prestados pelas seguradoras e pelas associaçóes. Sendo assim, não devem se submeter ao mesmo regime jurídico, especialmente no âmbito administrativo fiscalizatório, uma vez que são serviços distintos, operados por instituições distintas.

\subsection{Incompetência da SUSEP para fiscalizaçáo das Associaçóes De Proteçáo Veicular e a necessidade de criação de uma agência regulamentadora}

Conforme previamente discorrido, a Superintendência de Seguros Privados é uma autarquia federal e apresenta sua competência expressamente prevista em lei, em especial controle e fiscalização dos mercados de seguro, previdência privada aberta, capitalização e resseguro e ainda as atribuições previstas no art. 36 do 
Decreto-Lei n. 73 de 1966. Nesse sentido, possui competência para fiscalização somente das áreas voltadas ao mercado de seguro.

A atuação da SUSEP para criação e fiscalização das seguradoras está diretamente ligada à atuação administrativa do poder de polícia. Nos ensinamentos de Justen Filho (2012, p. 393), o poder de polícia é classificado da seguinte maneira: "O poder de polícia administrativa é a competência administrativa de disciplinar o exercício da autonomia privada para realização de direitos fundamentais e da democracia, segundo os princípios da legalidade e da proporcionalidade".

Contudo, ainda que a SUSEP tenha competência para exercer o poder de polícia, esta está vinculada exclusivamente às sociedades anônimas e cooperativas que veiculam seguros privados previamente autorizados pela própria autarquia. Sendo assim, quando fiscalizam Associaçôes de Proteção Veicular que são institutos civis e não vendem seguros, caracteriza-se o abuso de poder. Portanto, verifica-se o vício quanto à incompetência do sujeito, assim definido por Di Pietro (2017, p. 321):

Visto que a competência vem sempre definida em lei, o que constitui garantia para o administrado, será ilegal o ato praticado por quem não seja detentor das atribuiçôes fixadas na lei e também quando o sujeito o pratica exorbitando de suas atribuições. Nos termos do art. $2^{\circ}$ da Lei n. 4.717/65, a incompetência fica caracterizada quando o ato não se incluir nas atribuiçốes legais do agente que o praticou.

Nesse sentido, tendo em vista que as Associações de Proteção Veicular e as seguradoras possuem distinçóes claras no modo da prestaçáo de seus serviços, bem como no modo de constituição, o Decreto-Lei n. 73 de 1966 ou qualquer outra lei federal não ampliaram a competência da SUSEP para fiscalizar as Associaçóes de Proteção Veicular. Portanto, por não ter competência definida em lei, a Superintendência de Seguros Privados não é competente para fiscalização das associaçóes. Tem-se, portanto, excesso de poder da autarquia federal, como diz Di Pietro (2017, p. 232):

Constitui, juntamente com o desvio de poder, que é vício quanto à finalidade, uma das espécies de abuso de poder. Este pode ser definido, em sentido amplo, como o vício do ato administrativo que ocorre quando o agente público exorbita de suas atribuiçóes (excesso de poder), ou pratica o ato com finalidade diversa da que decorre implícita ou explicitamente da lei (desvio de poder). 
Assim, os atos praticados pela SUSEP decorrentes dessa atividade serão considerados nulos.

Pelo exposto, verifica-se que as intervençóes da autarquia do Sistema Nacional de Seguros Privados não são atos jurídicos válidos, eis que excedem sua competência prevista em lei. Nesse sentido, as Associações de Proteção Veicular não podem ser submetidas à fiscalização da SUSEP, uma vez que a autarquia é incompetente para tanto. Contudo, diante das recentes decisôes dos tribunais, discute-se a necessidade de criação de uma autarquia própria para fiscalização das instituiçóes.

Em que pese a legalidade das Associaçóes de Proteção Veicular de acordo com o ordenamento jurídico brasileiro e sua não submissão ao Sistema Nacional de Seguros Privados, em especial à SUSEP, é necessário verificar sua atuação indiscriminada no mercado brasileiro. O julgado abaixo, do STJ, analisou a atuação da Associação Mineira de Proteção e Assistência Automotiva (AMPLA):

CIVIL E ADMINISTRATIVO. RECURSO ESPECIAL. PODER FISCALIZATÓRIO DA SUPERINTENDÊNCIA DE SEGUROS PRIVADOS - SUSEP. PEDIDO DE INTERVENÇÃO DA CONFEDERAÇÃO NACIONAL DAS EMPRESAS DE SEGUROS GERAIS, PREVIDÊNCIA PRIVADA E VIDA, SAÚDE SUPLEMENTAR E CAPITALIZAÇÃO - CNSEG, COMO TERCEIRO PREJUDICADO. INDEFERIMENTO. PRELIMINAR DE NÃO CONHECIMENTO DO RECURSO INTERPOSTO PELA SUSEP. ALEGAÇÃO DE AUSÊNCIA DE PREQUESTIONAMENTO E DE AUSÊNCIA DE FUNDAMENTO SOBRE A PARTE DO RECURSO QUE SUSCITA A VIOLAÇÃO DO DISPOSITIVO DO ART. 535, II, DO CPC/1973. REJEIÇÃO. ALEGAÇÃO DA RECORRENTE - SUSEP DE OFENSA AO DISPOSITIVO DO ART. 535, II, DO CPC/1973. NÃO OCORRÊNCIA. ATIVIDADES DAASSOCIAÇÃO MINEIRA DE PROTEÇÃO E ASSISTÊNCIA AUTOMOTIVA. CARACTERIZAÇÃO COMO PRÁTICA SECURITÁRIA. ARESTO RECORRIDO QUE CONCLUIU PELA OCORRÊNCIA DE UM "GRUPO RESTRITO DE AJUDA MÚTUA”. ENUNCIADO N. 185 DA III JORNADA DE DIREITO CIVIL DO CONSELHO DA JUSTIÇA FEDERAL. INAPLICABILIDADE. VIOLAÇÃO DOS DISPOSITIVOS DOS ARTS. 757 DO CÓDIGO CIVIL/2002 E DOS ARTS. 24, 78 e 113 DO DECRETO-LEI 
N. 73/1966. RECURSO ESPECIAL INTERPOSTO PELA CONFEDERAÇÃO NACIONAL DAS EMPRESAS DE SEGUROS GERAIS, PREVIDÊNCIA PRIVADA E VIDA, SAÚDE SUPLEMENTAR E CAPITALIZAÇÃO - CNSEG PREJUDICADO. RECURSO ESPECIAL INTERPOSTO PELA SUPERINTENDÊNCIA DE SEGUROS PRIVADOS SUSEP CONHECIDO E PROVIDO (BRASIL, 2018).

Da análise do julgado extrai-se que a associação em comento, assim como algumas associaçóes, atua indiscriminadamente no mercado em desconformidade com as normas que regem a atividade associativa no Brasil. Da leitura do voto do Ministro OG Fernandes, verifica-se que, no caso analisado, havia cobrança de uma espécie de prêmio, assim como o contrato de seguro, sem rateio mensal entre todos os associados.

Ademais, uma vez que não havia o rateio, não havia ajuda mútua entre os associados e náo se configurava o grupo restrito de ajuda mútua conforme o enunciado 185 da III Jornada de Direito Civil disciplina. Dessa forma, a associação deixava de fornecer uma atividade associativa e fornecia um seguro irregular, vez que náo vinculado ao Sistema Nacional de Seguros Privados.

Além disso, o ministro relata que havia cobrança de franquia, bem como seguro contra terceiros, em clara tipificação do contrato de seguro. Todavia, em seu voto, o ministro afirma a possibilidade de associaçáo para rateio de despesas, conforme diz:

Inviável, destarte, afirmar a ilegalidade de toda e qualquer associação de pessoas unidas com o objetivo de ratear despesas diversas, apenas para assegurar a lucratividade e a competitividade das companhias seguradoras convencionais, em evidente cerceamento da autonomia da vontade e da liberdade de associação (BRASIL, 2018).

Nesse sentido, faz-se necessária a criação de uma autarquia reguladora para fiscalização das associações, tendo em vista a incompetência da SUSEP para fazêlo conforme discorrido anteriormente, e a necessidade de dar maior segurança às associaçôes e seus associados. Por meio de uma autarquia específica, é possível fiscalizar a atuação, a existência do rateio e do grupo restrito de ajuda mútua, bem como evitar a comercialização irregular dos seguros automotivos.

Nessa linha de pensamento, diz Rosa (2018):

[...] Porquanto, de um lado vemos a iniciativa social, amparada pelo diploma Constitucional, em seu art. 50, inc. XVII, cumulado com o Código Civil Brasileiro, que admite a existência de 
associaçôes que tenham uma finalidade comum, constituídas pela união de pessoas que se organizem para fins não econômicos [...].

Ainda de acordo com a autora:

[...] Por outro, vemos a falta de fiscalização e a liberdade da iniciativa sendo deturpada por atuaçóes mercantis e não sociais, ou seja, o exercício irregular da associação para obter lucro, ou até mesmo a falta de sustentabilidade que implica na instabilidade das associaçốes (ROSA, 2018).

A criação de uma autarquia fiscalizadora se faz necessária em razão da supremacia e indisponibilidade do interesse público, conforme dito por Justen Filho (2012, p. 36):

A supremacia do interesse público significa sua superioridade sobre os demais interesses existentes em sociedade. Os interesses privados não podem prevalecer sobre o interesse público. A indisponibilidade indica a impossibilidade de sacrifício ou transigência quanto ao interesse público e é decorrente de sua supremacia.

Portanto, diante da supremacia do interesse público, a criação de um órgão fiscalizador e de regulamentação das Associaçóes de Proteção Veicular se faz imprescindível para atender ao interesse dos associados, que em sua grande maioria são cidadãos não abarcados pelo contrato de seguro, mas que desejam proteger seu veículo. Todavia, diante da insegurança quanto ao modo de funcionamento e a regularidade das associaçôes, milhares de brasileiros se veem prejudicados por serviços irregulares e que são vendidos ilegalmente.

\subsubsection{Agência de Autorregulamentaçáo das Entidades de Autogestáo de Planos de Proteçáo Contra Riscos Patrimoniais}

Diante da inércia do poder público em aprovar o Projeto de Lei do Senado n. 356 de 2012, bem como em fiscalizar e regulamentar as associaçôes, e diante do crescimento e atuação indiscriminada, em 4 de maio de 2016 algumas associaçóes criaram uma nova associaçáo denominada Agência Autorregulamentadora das Associaçôes de Proteção Veicular no intuito de aperfeiçoar e fortalecer o movimento associativista.

Entre outras atuaçóes, tal agência visa operar como uma regulamentadora das associaçóes com seus associados, atuando para sanar os conflitos entre estes, estabelecendo valores éticos e morais no exercício da atividade associativa. 
Além disso, visa informar o poder público sobre associaçóes que trabalhem em desconformidade com a ideia do contrato de proteção automotiva, vendendo seguros de forma irregular, atuando como entidade fiscalizadora das associaçốes.

Contudo, a entidade está atuando no exercício do poder de polícia, dever público e indelegável, não sendo competente para fiscalizar as associaçóes. Por se tratar de uma questão de interesse público, faz-se necessário que a atividade de fiscalização das associaçóes seja exercida por um órgão de natureza jurídica pública, a fim de evitar que interesses de caráter privado se sobreponham ao interesse da sociedade.

\section{Conclusão}

Diante do que fora discorrido, evidencia-se que as Associaçôes de Proteção Veicular são institutos civis de direito privado que se pautam no rateio entre os associados dos prejuízos sofridos por todos os que estáo em consonância com o ordenamento jurídico brasileiro. Ademais, embora apresentem semelhanças com a atividade prestada pelas seguradoras privadas, devidamente autorizadas pela SUSEP, o contrato de proteção automotiva é totalmente diverso do contrato de seguro.

Nesse sentido, por prestarem atividades diversas, conclui-se que as associaçóes não se submetem ao Sistema Nacional de Seguros Privados, em especial, ao regime fiscalizatório da SUSEP. Dessa forma, todas as atividades exercidas pela SUSEP na tentativa de fiscalizar e regulamentar as associações são eivadas do vício de incompetência da autarquia para fiscalização.

Contudo, tendo em vista o crescimento da proteçáo automotiva e a ausência de fiscalização, algumas associaçôes tendem a comercializar seguros irregularmente, como indicado pelo STJ na análise do Recurso Especial n. 616359 RJ 2016/0194359-4, o que acaba por prejudicar a população e as próprias instituiçôes. Sendo assim, diante do interesse público e do esforço dos particulares na tentativa de fiscalizar as associaçóes, verifica-se que é necessária a criação de uma autarquia destinada a fiscalizar as associaçóes e assegurar os direitos dos associados na relação jurídica.

\section{Referências}

AAAPV - AGÊNCIA DE AUTORREGULAMENTAÇÃO DAS ENTIDADES DE AUTOGESTÃO DE PLANOS DE PROTEÇÃO CONTRA RISCOS PATRIMONIAIS. Site institucional. Disponível em: <http://www.aaapv.org.br/>. Acesso em: 08 set. 2019. 
BRASIL. Presidência da República. Casa Civil. Subchefia para assuntos jurídicos. Decreto-Lei n. 73, de 21 de novembro de 1966. Dispóe sôbre o Sistema Nacional de Seguros Privados, regula as operaçóes de seguros e resseguros e dá outras providências. Brasília, DF: Presidência da República, 1966. Disponível em: $<$ http://www.planalto.gov.br/CCIVil_03/Decreto-Lei/Del0073.htm>. Acesso em: 08 set. 2019.

BRASIL. Presidência da República. Casa Civil. Subchefia para assuntos jurídicos.. Constituição da República Federativa do Brasil de 1988. Brasília, DF: Presidência da República, 1988. Disponível em: <http://www.planalto.gov.br/ccivil_03/ constituicao/constituicaocompilado.htm>. Acesso em: 10 set. 2019.

BRASIL. Presidência da República. Casa Civil. Subchefia para assuntos jurídicos. Lei n. 10.406, de 10 de Janeiro de 2002. Institui o Código Civil. Brasília, DF: Presidência da República, 2002. Disponível em: <http://www.planalto.gov.br/ ccivil_03/leis/2002/110406.htm>. Acesso em: 08 set. 2019.

BRASIL. Superior Tribunal de Justiça. Processo - RES. 1616359-2016-01943594/RJ. Relator: OG Fernandes. Brasília, 21 de junho de 2018. Disponível em: $<$ https://stj.jusbrasil.com.br/jurisprudencia/594805956/recurso-especial-resp1616359-rj-2016-0194359-4?ref=juris-tabs>. Acesso em: 08 set. 2019.

BRITTO, C. A. O Regime Constitucional das Associações Civis. 19 de dezembro de 2016. Parecer jurídico. Disponível em: <https://onedrive. live. co m/? authkey=\%21 AL0dlbd7IG6zRms\&cid=1F74C2C9313BAF 47 \&id = 1F74C2C9313BAF47\%213521 \&parId=1F74C2C9313BAF47\%213522\&o=OneUp >. Acesso em: 08 set. 2019.

BULOS, U. L. Curso de Direito Constitucional. 5. ed. São Paulo: Saraiva, 2010. COELHO, F. U. Manual de Direito Comercial Brasileiro. 23. ed. São Paulo: Saraiva. 2011.

DI PIETRO, M. Z. Direito Administrativo. 30. ed. Rio de Janeiro: Forense, 2017. DINIZ, M. H. Curso de Direito Civil Brasileiro: Teoria Geral de Direito Civil. 29. ed. São Paulo: Saraiva, 2012.

FARIAS, C. C.; ROSENVALD, N. Direito Civil: Teoria Geral. 8. ed. Rio de Janeiro: Lumen Juris, 2009.

KRIGER FILHO, D. A. O contrato de seguro no Direito brasileiro. Rio de Janeiro: Frater et Labor Ediçóes Ltda., 2000. 
JUSTEN FILHO, M. Curso de Direito Administrativo. 2. ed. São Paulo: Saraiva, 2006.

MORAES, A. Direito constitucional. 33. ed. São Paulo: Atlas, 2017.

ROCHA, A. S. et al. $O$ dom da produção acadêmica: manual de normalizaçáo e metodologia da pesquisa. Belo Horizonte: Escola Superior Dom Helder Câmara, 2016, 120 p. Disponível em: <domhelder.edu.br/uploads/pesquisa/domdaproducaoacademica.pdf>. Acesso em: 08 set. 2019.

ROSA, I. L. Legalidade das Associaçôes de Proteçãoo Veicular no Cenário Jurídico Atual e a necessidade de regulamentação. Destrinchando, 26 mar. 2018. Disponível em: <http://www.destrinchando.com.br/legalidade-das-associacoes-de-protecao-veicular/>. Acesso em: 08 set. 2019.

SILVA, C. G. O.; RECHE, T. R. S. As diferenças entre as seguradoras e as associaçôes de proteção veicular: um enfoque jurídico. Letras Jurídicas, n. 3, p. 44-49, fev. 2014. Centro Universitário Newton Paiva. Disponível em: <http://npa.newtonpaiva.br/letrasjuridicas/wp-content/uploads/2015/06/LJ-0306.pdf>. Acesso em: 11 set. 2019.

SILVA, M. C. Contrato de Seguro de Automóveis: releitura à luz da nova principiologia do Direito Contratual. 1. ed. Rio de Janeiro: Lumen Juris, 2012.

SUSEP - SUPERINTENDÊNCIA DE SEGUROS PRIVADOS. Circular SUSEP n. 529 de 25 de fev. de 2016. Disponível em: <http://www2.susep.gov.br/bibliotecaweb/docOriginal.aspx?tipo=1\&codigo=37483>. Acesso em: 08 set. 2019. SUSEP - SUPERINTENDENCIA DE SEGUROS PRIVADOS. Site institucional. Disponível em: <http://www.susep.gov.br/menu/a-susep/apresentacao>. Acesso em: 08 set. 2019. 